ANSHUMAN CHAKRABORTY

\title{
DISPUTE SETTLEMENT UNDER THE UNITED NATIONS CONVENTION ON THE LAW OF THE SEA AND ITS ROLE IN OCEANS GOVERNANCE
}

\section{LLM THESIS}

FACULTY OF LAW

VICTORIA UNIVERSITY OF WELLINGTON

2006 


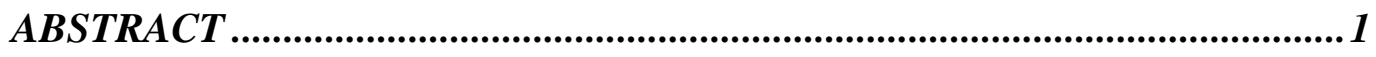

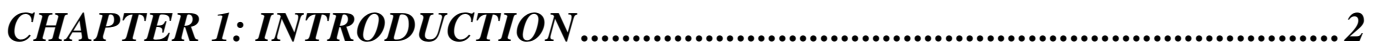

CHAPTER 2: OCEANS GOVERNANCE AND DISPUTE SETTLEMENT..10

I DEFINING GOVERNANCE ...................................................................... 12

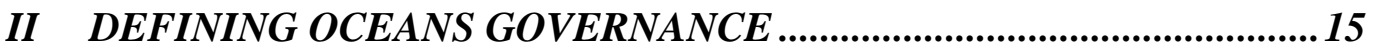

III LAW, DISPUTE SETTLEMENT AND GOVERNANCE ......................21

IV LAW, DISPUTE SETTLEMENT AND OCEANS GOVERNANCE ....... 28

A Regulate and Allocate Resources ........................................................440

B Maritime Boundary Delimitation ..........................................................45 45

C Strengthening Regimes and Institutions .............................................55

D Interpreting and Clarifying the Law and Developing Rules .................. 54

E Facilitating Co-operation..............................................................55

F Reducing Tensions, Ironing Out Problems, Maintaining Peace and

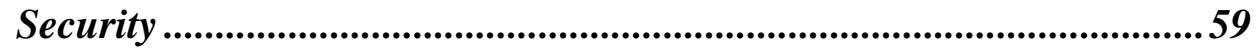

G Ensuring Compliance with, and Enforcement of, International Law .. 61

H Management of Multiple Ocean Use Conflicts ........................................ 65

V CONCLUSIONS ...............................................................................67

CHAPTER 3: INVOKING THE DISPUTE SETTLEMENT PROCEDURES69

I INTRODUCTION TO THE DISPUTE SETTLEMENT PROVISIONS IN

THE CONVENTION ............................................................................................ 70

A The Importance of Incorporating Dispute Settlement Provisions into the Convention......................................................................................... 71

B The Dispute Settlement Mechanisms of the Convention....................... 74

1 General provisions............................................................................ 74

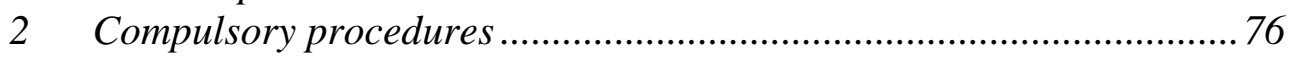

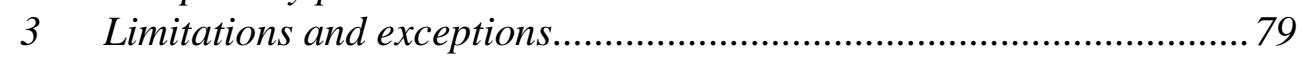

II PROMPT RELEASE CASES..........................................................82

A “Discounting" of Bonds...................................................................8 84

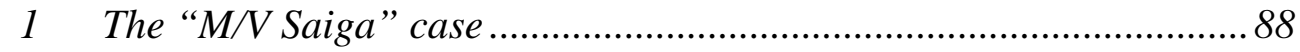

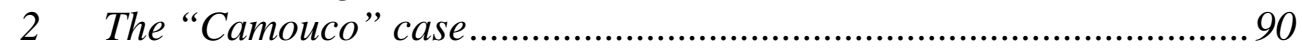

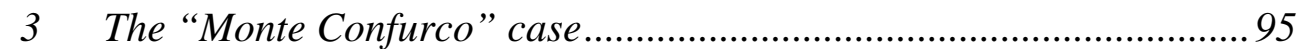

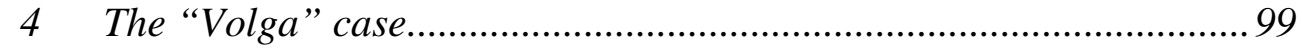

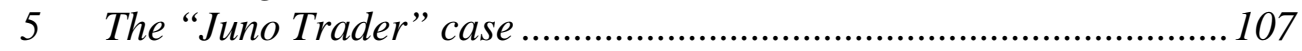

$6 \quad$ Uncertainty among coastal states ........................................................111

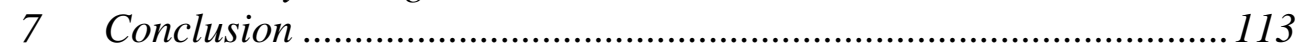

B Proceeds of the Catch in the Reasonableness of Bond.........................115

C Illegal, Unreported and Unregulated Fishing and Prompt Release Procedures ..............................................................................116

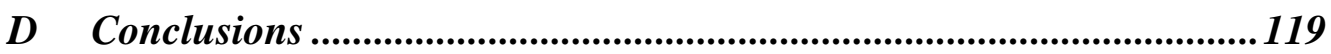


A The M/V "Saiga"(No. 2) Case (Provisional Measures) ...................... 122

B The $M / V$ “Saiga"(No. 2) Case (Merits).................................................... 124

1 Customs law enforcement in the EEZ ............................................ 125

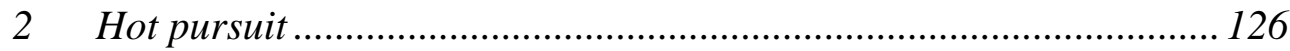

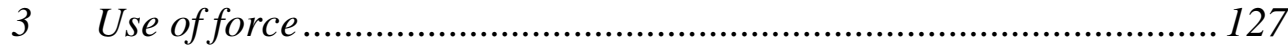

C The Southern Bluefin Tuna Cases (Provisional Measures) ............... 128

D The Southern Bluefin Tuna Case (Jurisdiction and Admissibility) ... 134

E The MOX Plant Case (Provisional Measures)................................... 139

F The MOX Plant Case (Further Provisional Measures) ....................... 142

$G$ The Case Concerning Land Reclamation by Singapore in and Around the Straits Of Johor (Provisional Measures) ....................................... 145

$H$ The Case Concerning Land Reclamation by Singapore in and Around the Straits Of Johor (Settlement Agreement and Award)..................... 146

I Conclusions ....................................................................................... 148

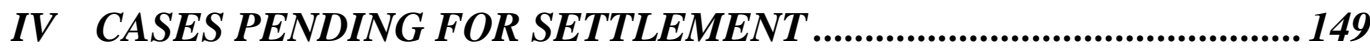

A The Case Concerning the Conservation and Sustainable Exploitation of Swordfish Stocks in the South-Eastern Pacific Ocean......................... 149

$B$ Dispute Concerning the Delimitation of the Exclusive Economic Zone and Continental Shelf Between Barbados and The Republic of Trinidad and Tobago ................................................................................. 151

C Dispute Concerning the Delimitation of the Maritime Boundary Between Guyana and Suriname .......................................................... 152

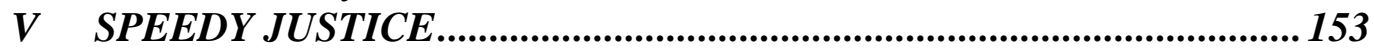

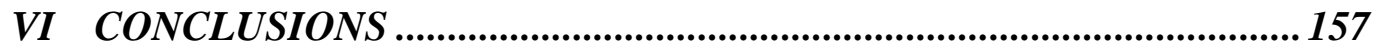

CHAPTER 4: THE INTERNATIONAL TRIBUNAL FOR THE LAW OF

THE SEA AND DEVELOPING COUNTRIES ............................................. 160

I DEFINING DEVELOPING COUNTRIES....................................... 163

II THE INTERNATIONAL TRIBUNAL FOR THE LAW OF THE SEA 167

AND DEVELOPING COUNTRIES ........................................................... 167

A Commitments Through Declarations and Agreement......................... 170

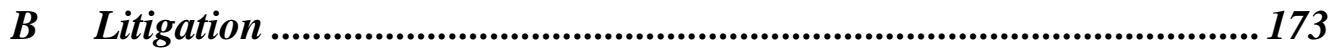

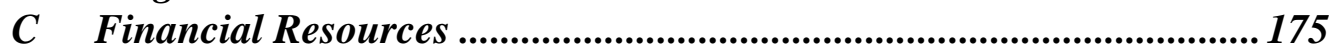

1 Contributions of states parties to the budget of the tribunal ............. 175

2 Financial assistance to developing countries for the settlement of

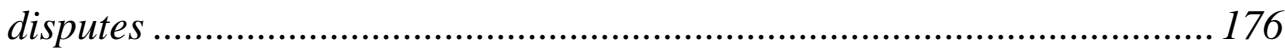

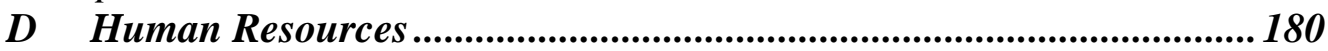

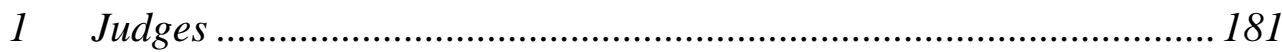

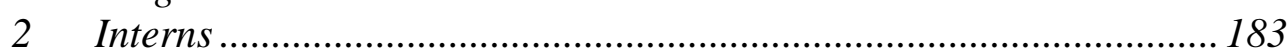

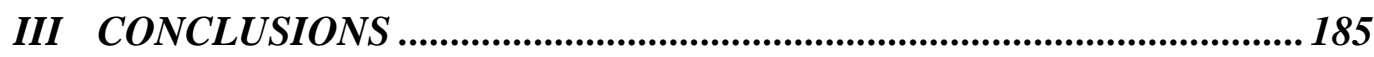

CHAPTER 5: THE FUTURE OF DISPUTE SETTLEMENT IN OCEANS GOVERNANCE .................................................................................................. 187

I POTENTIAL VERSUS ACTUAL ROLE ............................................ 187 
II INTERNATIONAL TRIBUNAL FOR THE LAW OF THE SEA: A CRITICAL ASSESSMENT

III RELUCTANCE OF STATES TO UTILISE FORMAL MEANS OF DISPUTE SETTLEMENT

IV LIMITATIONS AND OPTIONAL EXCEPTIONS TO COMPULSORY DISPUTE SETTLEMENT PROCEDURES 195

V A BETTER FUTURE FOR DISPUTE SETTLEMENT IN OCEANS

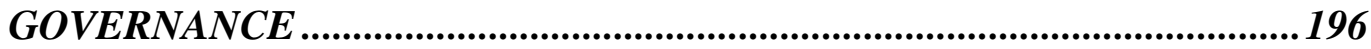

A Realising the Potential of Dispute Settlement Bodies............................198

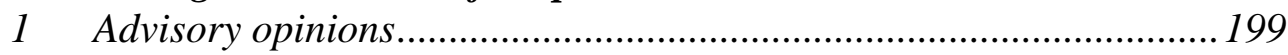

2 Using dispute settlement bodies in select cases .................................201

3 The increase in human population.....................................................201

$4 \quad$ Pre-selecting dispute settlement procedures.....................................202

B Political Will and Confidence in Dispute Settlement............................203

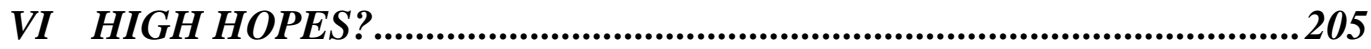

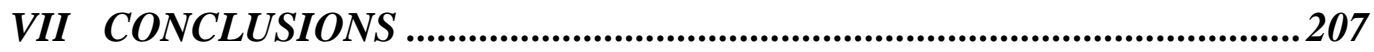

CHAPTER 6: CONCLUSIONS AND RECOMMENDATIONS ...................208

APPENDIX ONE: INDEX TO ABBREVIATIONS AND ACRONYMS......212 APPENDIX TWO: INDEX TO TABLES ..............................................217

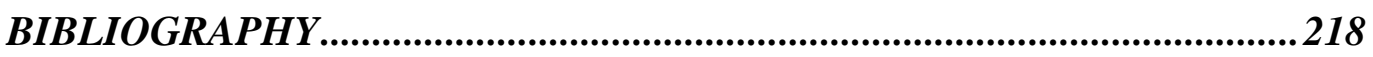




\begin{abstract}
This thesis is about the dispute settlement provisions of the 1982 United Nations Convention on the Law of the Sea (LOSC or Convention), and the potential and actual role that they play in oceans governance. The study focuses not only on the traditional role of dispute settlement mechanisms in peacefully settling disputes, but also on their potential for contribution to good oceans governance in many ways.

The jurisprudence generated so far under the dispute settlement provisions of the LOSC can be called neither a complete success nor a total failure. Part XV of the Convention, dealing with dispute settlement procedures, has made a promising start with the inaugural jurisprudence under the prompt release and provisional measures proceedings. However, besides the general beneficial influence of the jurisprudence on oceans governance, a few detrimental developments have also been identified from the perspective of oceans governance.

The present thesis demonstrates that a lot of hope had been pinned on the dispute settlement provisions at the time when the LOSC was drafted. However, most of these hopes have not yet found expression, and if the limited use of dispute settlement procedures continues, it is unlikely that Part XV will fulfil those hopes in the future. Nevertheless, this thesis argues along more optimistic lines, and expresses a realistic hope that the actual role of dispute settlement in oceans governance will improve in the future.

The thesis concludes that the success or failure of the dispute settlement mechanisms mostly depends upon their actual use made by states. Further, the dispute settlement mechanisms once invoked must be able to settle disputes objectively on the basis of law, equity and justice and uphold the principles and provisions of the LOSC. It is hoped that states will have recourse to Part XV more often for the purpose of settling their disputes peacefully, and that the dispute settlement provisions will in turn fulfil their mandate. Only then will the world witness the dispute settlement mechanisms playing a real and beneficial role in oceans governance, concurrently with other oceans governance institutions and arrangements.

This thesis is based on the law and available literature and as its date of submission for examination - 21 February 2006.
\end{abstract}

\title{
Word Length
}

The text of this thesis (excluding abstract, table of contents, footnotes, bibliography, and appendices) comprises approximately 53,630 words.

Subjects/ Topics: Law of the Sea - Oceans Governance - Dispute Settlement - United Nations Convention on the Law of the Sea 1982 (LOSC/ UNCLOS III) - International Tribunal for the Law of the Sea (ITLOS). 


\section{CHAPTER 1}

\section{INTRODUCTION}

At the outset, a thesis discussing the role of dispute settlement on oceans governance merits the question: why is oceans governance important? What is it about oceans governance that deserves attention? The oceans dominate over 70 per cent of the physical geography of the Earth and play a major role in the life support systems of the planet. The oceans "in terms of geography, development, economy and trade, conflict and security and culture and way of life" ${ }^{1}$ have influenced human civilisation since time immemorial. The oceans have great impact on human life and are significant from the ecological, economic, political and social $^{2}$ points of view. ${ }^{3}$ The oceans have far reaching effects on the development and sustainability of human society, in the maintenance of global peace and the health of the biosphere. ${ }^{4}$ Through the passage of time, humans have become increasingly dependant on the oceans for sustenance and livelihood, and the rapid advancement in science and technology aimed at harnessing and harvesting the oceans bear testimony to the importance of oceans to human life. ${ }^{5}$

As one commentator has argued, the oceans have special characteristics and due to their varied usage by humans, a number of unique problems are

\footnotetext{
${ }^{1}$ Glen J Herbert and Timothy M Shaw "Oceans Governance and Human Security Towards the End of the Century: Regional Approaches" in Aldo Chircop, Andre Gerolymatos and John O Iatrides (eds) The Aegean Sea After the Cold War: Security and Law of the Sea Issues (Macmillan Press Ltd, London, 2000) 206, 206.

${ }^{2}$ See Philip E Steinberg The Social Construction of the Ocean (Cambridge University Press, Cambridge, 2001).

${ }^{3}$ For a brief analysis of the importance of the oceans, see Robert Constanza "The Ecological Economic, and Social Importance of the Oceans" (1999) 31 Ecological Economics 199 ["The Ecological Economic, and Social Importance of the Oceans"]. For more detailed discussions, see Elisabeth Mann Borgese The Oceanic Circle: Governing the Seas as a Global Resource (United Nations University Press, Tokyo, 1998) 23 - 108 [The Oceanic Circle: Governing the Seas as a Global Resource]; S G Gorshkov The Sea Power of the State (Naval Institute Press, Annapolis (Maryland), 1976) 6- 27.

${ }^{4}$ Robert Constanza and others "Principles of Sustainable Governance of the Oceans" (1998) 281 Science 198, 198 ["Principles of Sustainable Governance of the Oceans"].

${ }^{5}$ See Paul M Fye and others "Ocean Science and Marine Resources" in Uses of the Seas (Prentice-Hall Inc, Englewood Cliffs (New Jersey), 1968) 17; Joseph J Kalo and others Coastal and Ocean Law: Cases and Materials (3 ed, West Group, St Paul, Minnesota, 1999) 323 - 325.
} 
spawned which need to be effectively tackled in their governance structure. ${ }^{6}$ Inability to do so would lead to a situation where nations as independent actors on the world stage would increasingly suffer mutual losses or fail to reap joint gains. ${ }^{7}$ Similarly, others have suggested that a lack of understanding and information about marine resources and the processes and threats facing them is responsible for some of the major challenges encountered in the oceans governance process. ${ }^{8}$ Oceans governance largely involves the governance of the common pool resources that it contains - be it the fishes and other marine living beings or the minerals and other non-living resources. Oceans governance necessitates ensuring that the oceanic resources are managed in a sustainable and peaceful manner.

There is an urgency being increasingly felt worldwide that, unless the oceans are governed in a sustainable manner, irreparable harm may befall the world due to the pressure from human life. ${ }^{9}$ A workshop organised by the Independent World Commission on the Oceans (IWCO) ${ }^{10}$ identified five major problems facing the oceans today - overfishing, ${ }^{11}$ ocean disposal and spills,

\footnotetext{
6 "The Ecological Economic, and Social Importance of the Oceans", above n 3, 205. See also Emily Corcoran A Survey of Global and Regional Marine Environmental Assessments and Related Scientific Activities (United Nations Environment Programme - World Conservation Monitoring Centre, Cambridge, 2003) available at $<\mathrm{http}: / / \mathrm{www}$.unepwcmc.org/marine/GMA/docs/GMA_Review.pdf> (last accessed 11 November 2005) 10.

${ }^{7}$ See Oran R Young International Governance: Protecting the Environment in a Stateless Society (Cornell University Press, Ithaca, 1994) 19 [International Governance: Protecting the Environment in a Stateless Society].

${ }^{8}$ Paula Antunes and Rui Santos "Integrated Environmental Management of the Oceans" (1999) 31 Ecological Economics 215, 224.

${ }^{9}$ See generally John Temple Swing "What Future for the Oceans?" (2003) 82 (5) Foreign Aff 139. For more recent concerns aired internationally, see International Institute for Sustainable Development "A Summary Report of The Ocean Policy Summit (TOPS): 11 - 13 October 2005" (2005) available at <http://www.iisd.ca/sd/tops2005/> (last accessed 17 October 2005); International Institute for Sustainable Development "A Summary Report of the Third Global Conference on Oceans, Coasts and Islands 'Moving the Global Oceans Agenda Forward': 24 28 January 2006" (2006) available at <http://www.iisd.ca/ymb/globaloceans3/> (last accessed 31 January 2006); GESAMP and Advisory Committee on Protection of the Sea A Sea of Troubles (UNEP, GESAMP Reports and Studies 70, London, 2001); Richard Ellis The Empty Ocean: Plundering the World's Marine Life (Island Press, Washington DC, 2003); The World Conservation Union Creating a Sea Change (WWF/IUCN, Gland, Switzerland, 1998).

${ }^{10}$ See Robert Constanza and Francisco Andrade (eds) Ecological Economics and Sustainable Governance of the Oceans (Fundação Luso-Americana para o Desenvolvimento, IMAR-Instituto do Mar, Lisbon, 1998).

${ }^{11}$ See FAO Review of the State of World Marine Fishery Resources (FAO Fisheries Technical Paper 457, FAO, Rome, 2005) 8. See also Jennifer L Talhelm "Curbing International Overfishing and the Need for Widespread Ratification of the United Nations Convention on the Law of the Sea” (2000) 25 N C J Intl L \& Com Reg 381.
} 
destruction of coastal ecosystems, land-based pollution and climate change. ${ }^{12}$ Since the last decades of the twentieth century, humans have been the governing force shaping the ecology of the planet both on land as well as the oceans. ${ }^{13}$ The nature and scale of human induced changes that the geology and ecology of the Earth have witnessed have led scientists to propose the term "anthropocene" for the present geological epoch. ${ }^{14}$

Humans are by their intrinsic nature driven to conflicts with one another and disputes over rights and resources. The oceans have long served as the 'battlefield' for the navies of the world or the medium to get to the actual battlefields. Sea power has shaped the fate of many nations and human history has shown that more often than not the future of a country has been determined by its use and control of the sea and its resources. ${ }^{15}$ History demonstrates a continuous association existing between the oceans and disputes, with a marked increase in the trend in the more recent past of human existence on Earth. ${ }^{16}$ This is hardly surprising, given the large number of nearly 200 countries that the world is divided into and their corresponding interests in the oceans that are often in conflict with one another. Therefore for peaceful co-existence on this planet, countries have felt the need to have international laws and regulations in place, and provisions for the peaceful settlement of disputes are the sin qua non of such a legal order. ${ }^{17}$

The United Nations Convention on the Law of the Sea ${ }^{18}$ (LOSC or Convention) was designed as a document that recognised that the problems of

\footnotetext{
12 "Principles of Sustainable Governance of the Oceans", above n 4, 198.

13 Stephen B Olsen and others "A Global Network for Sustained Governance of Coastal Ecosystems" in Linda K Glover and Sylvia A Earle (eds) Defying Ocean's End: An Agenda for Action (Island Press, Washington DC, 2004) 151, 153.

14 Paul J Crutzen and Eugene F Stoermer "The Anthropocene" (2000) 41 Global Change Newsletter 17, 17, available at <http://www.igbp.kva.se//uploads/nl_41.pdf > (last visited 22 November 2005).

${ }^{15}$ See generally Alfred Thayer Mahan The Influence of Sea Power Upon History 1660-1783 (First published in 1890 by Little, Brown \& Co, Boston (Mass); reprint, Methuen \& Co Ltd, London, 1965).

${ }^{16}$ See James C F Wang Handbook on Ocean Politics and Law (Greenwood Press, New York, 1992) $107-142$.

${ }^{17}$ See S G Gorshkov The Sea Power of the State (Naval Institute Press, Annapolis (Maryland), 1976) 46.

${ }^{18}$ United Nations Convention on the Law of the Sea, opened for signature 10 December 1982, 1833 UNTS 3 [LOSC].
} 
ocean space were closely related and demanded consideration as a whole. ${ }^{19}$ The LOSC was said to have responded to the challenges of modern day oceans governance that is fraught with interdependent, interdisciplinary and transsectoral implications. ${ }^{20}$ The issues in or behind the Convention held plenty of potential for conflicts among nations. ${ }^{21}$ Therefore states perceived the need for having robust dispute settlement provisions in the LOSC. ${ }^{22}$ The dispute settlement provisions enshrined in Part XV, along with Annexes V - VIII of the LOSC, form the backbone of the dispute settlement system of the present law of the sea. ${ }^{23}$ It has been said that " $[\mathrm{t}]$ he oceans are a critical forum for addressing conflicts ... and oceans governance seeks to transform problems into opportunities. ${ }^{24}$ It is in such an idea that the role of dispute settlement in oceans governance can be perceived quite clearly.

The date 16 November 1994 marked a historic day when the LOSC entered into force, ${ }^{25}$ seeking to govern the uses of the oceans of the world. During the 11 years that it has been in force, the dispute settlement provisions in it have been utilised on several occasions. However, this period of time is quite short for the purpose of making a definitive assessment of its effectiveness. ${ }^{26}$ It may also appear premature to draw definite conclusions and see if the provisions

\footnotetext{
${ }^{19}$ LOSC, Preamble. See Arvid Pardo "Perspectives on Ocean Governance" in Jon M Van Dyke, Durwood Zaelke and Grant Hewison (eds) Freedom for the Seas in the 21st Century: Ocean Governance and Environmental Harmony (Island Press, Washington DC, 1993) 38, 39.

${ }^{20}$ See Elisabeth Mann Borgese Ocean Governance and the United Nations (Centre for Foreign Policy Studies, Halifax, 1995) 2 [Ocean Governance and the United Nations]; John R Stevenson and Bernard H Oxman "The Future of the United Nations Convention on the Law of the Sea" (1994) 88 AJIL 488, 490. See generally Philip Allott "Power Sharing in the Law of the Sea" (1983) 77 AJIL 1.

${ }^{21}$ Laurence Martin "The Role of Force in the Ocean" in Perspectives on Ocean Policy: Conference on Conflict and Order in Ocean Relations October 21-24, 1974, Airlie, Virginia (National Science Foundation, Washington DC, 1975) 33, 44. See generally John Temple Swing "Who Will Own the Oceans?" (1976) 54 (3) Foreign Aff 527; Barry Buzan "A Sea of Troubles? Sources of Disputes in the New Ocean Regime" (International Institute of Strategic Studies, London, 1978).

${ }^{22}$ Louis B Sohn "Peaceful Settlement of Disputes in Ocean Conflicts: Does UNCLOS III Point the Way?" (1983) 46 Law \& Contemp Probs 195.

${ }^{23}$ Budislav Vukas "Possible Role of the International Tribunal for the Law of the Sea in Interpretation and Progressive Development of the Law of the Sea" in Davor Vidas and Willy Østreng (eds) Order for the Oceans at the Turn of the Century (Kluwer Law International, The Hague, 1999) 95, 95 ["Possible Role of the International Tribunal for the Law of the Sea in Interpretation and Progressive Development of the Law of the Sea"].

${ }^{24}$ Herbert and Shaw, above n 1, 221.

${ }^{25}$ Oceans and Law of the Sea $<$ http://www.un.org/Depts/los/index.htm $>$ (last accessed 26 August 2005).

${ }^{26}$ Rosemary Rayfuse "The Future of Compulsory Dispute Settlement Under the Law of the Sea Convention" (2005) 36 VUWLR 683, 684 ["The Future of Compulsory Dispute Settlement Under the Law of the Sea Convention"].
} 
have achieved some of the lofty goals that led to their creation. But as this landmark treaty still continues to gain global acceptance, ${ }^{27}$ it is certainly worthwhile to analyse the jurisprudence that has emerged over the past decade pursuant to the use of Part XV. Given the jurisprudence generated by the LOSC's dispute settlement machinery so far, there is not a sizeable amount to work with. However, the jurisprudence of the young International Tribunal for the Law of the $\mathrm{Sea}^{28}$ (ITLOS or Tribunal) through its formative stages has begun to claim a status of its own with regard to cases seeking prompt release of vessels and crews. $^{29}$ The Tribunal has also had occasion to deal with a few cases seeking provisional measures. Thus an enquiry into the judicial developments that have taken place so far under Part XV is justified.

Taken separately, there exists a great volume of literature on dispute settlement under the law of the sea, and comparable quantity of commentary on oceans governance, as are referred to and acknowledged through the length of the thesis. However, very little has been written linking dispute settlement and oceans governance. Distinguished authors writing on the governance of the global commons have acknowledged that the role of diverse mechanisms for dispute settlement in governance is significant, though not much work has been done in this regard and therefore this remains an important area for research. ${ }^{30}$ To the author's knowledge, only two commentators have to date directly addressed the role of dispute settlement in oceans governance, though only to a limited extent. ${ }^{31}$ The aim of this thesis is to explore this area in much greater detail and bring out the possible links between dispute settlement and oceans governance in a clear and precise manner. The central thesis here is that dispute settlement has an important role to play in oceans governance. Although in terms

\footnotetext{
${ }^{27}$ As of 26 August 2005, there are 149 States Parties to the LOSC. Oceans and Law of the Sea, above $\mathrm{n} 25$.

${ }^{28}$ LOSC, Annex VI.

29 The "Juno Trader" Case (Saint Vincent and the Grenadines v Guinea-Bissau) (Prompt Release) [2004] <http://www.itlos.org/> (last accessed 1 December 2005) para 5 Judge Park' Separate Opinion [The "Juno Trader" - Judge Park].

${ }^{30}$ Thomas Dietz and others "The Drama of the Commons" in Elinor Ostrom and others (eds) The Drama of the Commons (National Academy Press, Washington DC, 2002) 3, 15.

${ }_{31}$ See Louis B Sohn "The Role of Dispute Settlement in Ocean Governance" in Thomas A Mensah (ed) Ocean Governance: Strategies and Approaches for the 21st Century (The Law of the Sea Institute, University of Hawaii, Honolulu, 1994) 235 ["The Role of Dispute Settlement in Ocean Governance"]; Ted L McDorman, "Global Ocean Governance and International Adjudicative Dispute Resolution" (2000) 43 Ocean \& Coastal Management 255, 257 ["Global Ocean Governance and International Adjudicative Dispute Resolution”].
} 
of potential, dispute settlement scores high in its role in oceans governance, its actual role has been rather limited to date.

Chapter 2 begins with a definition of governance and is followed by discussion on the meaning of oceans governance. This is followed by a discussion on the connections between law, dispute settlement and governance. The next part carries out an argument about the connections between law, dispute settlement and oceans governance. The chapter then examines the role of dispute settlement in oceans governance under eight non-exhaustive heads. This chapter concludes with the finding that there exists considerable potential for dispute settlement to play a role in oceans governance. It is also suggested that the first step to realising this potential lies in the actual use of dispute settlement procedures in real dispute situations.

In Chapter 3, the existing jurisprudence under Part XV is analysed. This author acknowledges that there are many controversial aspects of the existing jurisprudence, which have not been covered in the present thesis. This is because the object of this thesis is to analyse the role of the dispute settlement mechanisms in oceans governance and therefore the analysis of the case law has been confined to this perspective alone. Therefore, the thesis accounts for and discusses only those aspects of the jurisprudence, which the author believes to have the most impact on oceans governance - constructive or otherwise. In particular, the impact or the potential of the influence of the cases on oceans governance are explored.

Part I of Chapter 3 gives a brief introduction into the core dispute settlement provisions of the Convention. Part II identifies some of the ways in which the prompt release jurisprudence appears to threaten the cause of good oceans governance. The marked trend in the Tribunal's jurisprudence of significantly reducing the bonds sought for the release of detained vessels and crews is discussed at length for each individual case so far. In part III of the chapter, the provisional measures cases are discussed, followed by a summary of the subsequent judicial proceedings. It finds that largely the impact of provisional measures cases and subsequent judicial proceedings has been quite positive for oceans governance. Part IV of the chapter is devoted to recognising the expeditious handling of cases by ITLOS and argues that this has a constructive impact on oceans governance. Part V of the chapter gives a brief account of three 
cases invoked under Part XV of the LOSC that are currently pending. The chapter concludes that, though the overall effect of the Part XV jurisprudence so far has been largely constructive, the magnitude of the impact has been much less significant. The reason for this is ascribed to the fact that the majority of the cases have been interlocutory in nature and have had a limited impact on state policy and action and hence had a restricted role in oceans governance. It is hoped that the submission of disputes in their merits phase to dispute settlement mechanisms will nevertheless unlock their real potential in oceans governance.

Chapter $4^{32}$ is in the nature of a practical case study for a detailed investigation into the interactions between a dispute settlement body under the LOSC, and states parties. For the purpose of this study, ITLOS is the chosen dispute settlement body, since it has special import as the only independent international judicial tribunal of permanent standing that the LOSC created for the settlement of disputes relating to its interpretation and application. ${ }^{33}$ As for the states parties, the author has selected and treated developing countries as a group, which, though often differing in their interests in ocean issues, stood unified on common ground during the Third United Nations Conference on the Law of the Sea (UNCLOS III). ${ }^{34}$ As developing countries progressively develop further, one of the natural consequences of that is an increasing impact on oceanic resources. Therefore there is an increasingly important role for developing countries in oceans governance. Additionally, since developing countries played an important role in drafting of the LOSC and its dispute settlement provisions, it is useful to consider the extent to which they have participated in the dispute settlement process in their oceans governance initiatives.

Taken together in perspective of the links between dispute settlement and oceans governance, ITLOS and developing countries are seen to be in active

\footnotetext{
${ }^{32}$ This chapter had its beginnings in a research article that the author presented to the Legal Office of ITLOS. The author hails from a developing country and served at ITLOS from 15 December 2004 to 15 February 2005. The author is grateful for the support received from the Faculty of Law, Victoria University of Wellington and the sponsorship from the Korea International Cooperation Agency Grant. See Annex III, Annual Report of the International Tribunal for the Law of the Sea 2004, UN Doc SPLOS/122 [ITLOS Annual Report 2004].

${ }^{33}$ See LOSC, art 287 and Annex VI.

${ }^{34}$ The Third United Nations Conference on the Law of the Sea, 1973 - 1982. See generally Elisabeth Mann Borgese "What Can Developing Countries Gain from the United Nations Convention on the Law of the Sea?" (1985) 6 Trade \& Dev 123.
} 
interaction, beginning with the earliest efforts directed at the establishment of ITLOS. Chapter 4 begins by defining and identifying developing countries for the purpose of the study. It then highlights the various levels of engagement between ITLOS and developing countries through declarations and agreements, litigation, financial resources and human resources. The chapter concludes that ITLOS is instrumental in promoting good oceans governance among developing countries both within the arena of dispute settlement as well as outside it. The central argument of this chapter is that by helping developing countries in increasing their participation in dispute settlement procedures, ITLOS is increasing chances of the utilisation of the dispute settlement procedures, and therefore enhancing their chances of contributing to oceans governance along the lines as identified in chapter 2.

Chapter 5 draws together the findings from chapters 2 and 3 , and demonstrates how the dispute settlement mechanisms have actually measured up against their potential role in oceans governance. It is seen that the dispute settlement mechanisms have still got a long way to go before realising the true potential in their role in oceans governance in the future. It is argued that this goal cannot be achieved by dispute settlement provisions in isolation and requires states to utilise them more often in the settlement of their disputes. A few other recommendations and suggestions are made for improving the role of dispute settlement in oceans governance.

In chapter 6 , the findings of this thesis are recapitulated and reasserted. The chapter concludes by summarising the recommendations foreshadowed in various parts of the thesis that would, if carried into effect, possibly lead to good oceans governance achieved with constructive contribution from the dispute settlement mechanisms. In sum, the central thesis that dispute settlement mechanisms have a real and significant role to play in oceans governance is reiterated. 


\section{CHAPTER 2}

\section{OCEANS GOVERNANCE AND DISPUTE SETTLEMENT}

The aim of this chapter is to provide a largely theoretical inquiry into the connections between oceans governance and dispute settlement, and the potential role of dispute settlement in oceans governance. Oceans governance is a relatively new concept that has been increasingly discussed within the sphere of ocean law as well as other sectors of ocean use and management. One author has commented that oceans governance has become an increasingly important issue especially for coastal states since the deliberations of the United Nations Conferences on the Law of the Sea from 1958 to $1982 .{ }^{35}$ It has been suggested elsewhere that interest in both oceans governance and dispute settlement has grown considerably since the entry into force of the LOSC on 16 November $1994 .^{36}$

A good amount of literature has been generated on oceans governance at regional $^{37}$ and national ${ }^{38}$ levels. Within the legal literature on the LOSC, there has been considerable discussion on international oceans governance. ${ }^{39}$ Such

\footnotetext{
${ }^{35}$ Joanna Vince "Policy Transfer in Ocean Governance: Australia, Canada and New Zealand" in Australasian Political Studies Association Conference 2005 (Otago, 2005) 2.

36 Donald R Rothwell "The International Tribunal for the Law of the Sea and Marine Environmental Protection: Expanding the Horizons of International Oceans Governance" (2003) 17 Ocean Yearbook 26.

${ }^{37}$ As illustrations, see Joeli Veitayaki, Nathan Evans and G Robin South "The Pacific Islands Regional Ocean Policy: The Quest for Good Ocean Governance" (2004) 18 Ocean Yearbook 558; Tamari'i Tutangata and Mary Power "The Regional Scale of Ocean Governance Regional Cooperation in the Pacific Islands" (2002) 45 Ocean \& Coastal Management 873; Barbara Kwaitkowska "Institutional Marine Affairs Cooperation in Developing State Regions': Part I: General Problems and Prospects" (1990) 14 Marine Policy 385; Barbara Kwaitkowska "Institutional Marine Affairs Cooperation in Developing State Regions: Part II: The Indian Ocean and IOMAC" (1990) 14 Marine Policy 399; G L Holland "The Role of Intergovernmental Organizations in Coastal Zone Management" (1998) 39 Ocean \& Coastal Management 25.

${ }^{38}$ For example, see Lawrence Juda "Changing National Approaches to Ocean Governance: The United States, Canada, and Australia" (2003) 34 ODIL 161; Bruce W Davis "Contemporary Ocean and Coastal Management Issues in Australia and New Zealand: An Overview" (1996) 33 Ocean \& Coastal Management 5; Jonathan Side and Paul Jowitt "Technologies and their Influence on Future UK Marine Resource Development and Management" (2002) 26 Marine Policy 231; Edward L Miles "Future Challenges in Ocean Management: Towards Integrated National Ocean Policy" in Paolo Fabbri (ed) Ocean Management in Global Change (Elsevier Applied Science, London, 1992) 595; Hance D Smith "The Role of the State in the Technical and General Management of the Oceans" (1995) 27 Ocean \& Coastal Management 5.

39 See Lee A Kimball International Ocean Governance: Using International Law and Organizations to Manage Marine Resources Sustainably (IUCN, Gland, Switzerland, 2001) [International Ocean Governance: Using International Law and Organizations to Manage Marine Resources Sustainably]; Yoshifumi Tanaka "Zonal and Integrated Management
} 
discussions have concentrated mainly on the impact of various aspects of the LOSC on oceans governance. To a certain extent the functions carried out by organisations and agencies both public and private operating at international, regional and national levels has also been discussed. ${ }^{40}$ However, there has not been much attention drawn to dispute settlement under the law of sea and its possible role in the oceans governance process. The author believes that the dispute settlement machinery available under the LOSC has an important role to play in oceans governance, including but extending beyond the traditional function of peacefully settling disputes.

In the following paragraphs, the terms 'global oceans governance' and 'oceans governance' are used inter-changeably, unless where otherwise indicated. Similarly, for the sake of simplicity, the terms 'dispute' and 'conflict' and related expressions are used synonymously, though it is recognised that there exists a body of literature that distinguishes between the two. ${ }^{41}$ Part I contains a definitional analysis of 'governance' particularly as it relates to international issues. It is seen that there exists great disparity in the definitions and theories of governance and it is not easy to reconcile all of them. Part II discusses the meaning of 'oceans governance' and tries to put it into perspective for the purposes of part IV. Part III attempts to discover the linkages between law, dispute settlement and governance. This is followed by part IV, which discusses the connections between law, dispute settlement and oceans governance. It is

Approaches to Ocean Governance: Reflections on a Dual Approach in International Law of the Sea" (2004) 19 (4) IJMCL 483 ["Zonal and Integrated Management Approaches to Ocean Governance"]; Jose Manuel Pureza "International Law and Ocean Governance: Audacity and Modesty” (1999) 8 (1) RECIEL 73.

${ }^{40}$ See International Ocean Governance: Using International Law and Organizations to Manage Marine Resources Sustainably, above n 39. See also Lee A Kimball "The Role of NGOs in the Implementation of the 1982 LOS Convention" in Alfred H A Soons (ed) Implementation of the Law of the Sea Convention through International Institutions (Law of the Sea Institute, University of Hawaii, Honolulu, 1990) 139.

${ }^{41}$ John Collier and Vaughan Lowe The Settlement of Disputes in International Law: Institutions and Procedures (Oxford University Press, Oxford, 1999) 1; John W Burton "Dispute-Conflict Distinction" in Conflict: Resolution and Provention (St Martin's Press, New York, 1990) 2. See also Douglas H Yarn "Conflict" in Douglas H Yarn (ed) Dictionary of Conflict Resolution (Jossey-Bass, San Francisco, 1999) 115; Louis Kriesberg "The Development of the Conflict Resolution Field" in I William Zartman and J Lewis Rasmussen (eds) Peacemaking in International Conflict (United States Institute of Peace Press, Washington DC, 1997) 64 - 65. For an interesting explanation of the differences between conflicts and disputes and a diagrammatic explanation of the relationship between them, see generally Heidi Burgess and Brad Spangler "The Difference Between Conflict and Dispute" in Guy Burgess and Heidi Burgess (eds) Dispute Resolution Consortium (University of Colorado, Boulder, Colorado, 2003) available at $<$ http://www.beyondintractability.org/m/conflicts_disputes.jsp $>$ (last accessed 5 November 2005). 
revealed that the cardinal issues of oceans governance are found in the legal, economic and ecological management arenas. ${ }^{42}$ It is shown that international dispute settlement also finds a place in the smorgasbord of key elements that facilitate the cause of good global oceans governance. Part IV also reveals that dispute settlement's contribution in the oceans arena extends but is not limited to its role in eight important areas.

\section{DEFINING GOVERNANCE}

To begin with, it is necessary to provide an explanation of the word 'governance,' although defining governance is not an easy proposition. Different entities such as agencies, international organisations, regional institutions and academicians define governance in different ways, each analysis reflecting the bias of each observer. In this section, the discussion on governance is in the international perspective or what in general has been called global governance. ${ }^{43}$ Often the definitions cited in this section have strong national connotations but it is submitted that they are quite relevant even in the international arena, as will be clear from a perusal of the definitions themselves. In fact, though definitions of governance abound, most of which happen to be in the national context, only those of consequence in the international front have been used here.

Governance, it has been said, "is now fashionable but the concept is as old as human history." 44 To start with, it is meaningful to look at the definition of governance provided by the World Bank: ${ }^{45}$

\footnotetext{
[T] he traditions and institutions by which authority in a country is exercised for the common good. This includes (i) the process by which those in authority are selected, monitored and replaced, (ii) the capacity of the government to effectively manage its resources and implement sound policies, and (iii) the respect of citizens and the state for the institutions that govern economic and social interactions among them.
}

\footnotetext{
${ }^{42}$ See generally Adalberto Vallega Sea Management: A Theoretical Approach (Elsevier Applied Science, London, 1992).

${ }^{43}$ For a good collection of writings on global governance theory, see Martin Hewson and Timothy J Sinclair (eds) Approaches to Global Governance Theory (State University of New York Press, Albany, 1999).

${ }^{44}$ Thomas G Weiss "Governance, Good Governance and Global Governance: Conceptual and Actual Challenges" (2000) 21 (5) Third World Quarterly 795, 795.

45 The World "About Governance" $<$ http://www.worldbank.org/wbi/governance/about.html $>$ (last accessed 20 October 2005).
} 
As a regional institution of significant weight, actively involved in policy and law making within the European Union, the European Commission (EC) defines governance as: ${ }^{46}$

Governance refers to the rules, processes, and behaviour by which interests are articulated, resources are managed, and power is exercised in society. ... In spite of its open and broad character, governance is a meaningful and practical concept relating to the very basic aspects of the functioning of any society and political and social systems. It can be described as a basic measure of stability and performance of a society. ... Today governance is generally used as a basic measure of quality and performance of any political/ administrative system.

An academic definition of governance is: ${ }^{47}$

By governance, we mean the processes and institutions, both formal and informal, that guide and restrain the collective activities of a group. Government is the subset that acts with authority and creates formal obligations. Governance need not necessarily be conducted exclusively by governments and the international organizations to which they delegate authority. Private firms, association of firms, nongovernmental organizations (NGOs), and associations of NGOs all engage in it, often in association with governmental bodies, to create governance; sometimes without governmental authority.

Similarly, political scientist Roderick Rhodes argues that the concept of governance, currently used in social sciences, is popular but imprecise. ${ }^{48}$ Rhodes suggests, "governance refers to self-organizing, interorganizational networks characterised by independence, resource exchange, rules of the game and significant autonomy from the state." 49 Though Rhodes' views are not directly relevant in the international context, it is necessary to point to the distinction Rhodes draws between 'government' and 'governance,' which is applicable even in global governance. ${ }^{50}$

\footnotetext{
${ }^{46}$ Commission of the European Communities, COM (2003) 615 final, Communication from the Commission to the Council, the European Parliament and the European Economic and Social Committee, Governance and Development, 3 - 4. Reported in "Development Cooperation" (2003) $\quad 10 \quad$ Bulletin EU 1.6.37. <http://europa.eu.int/eurlex/en/com/cnc/2003/com2003_0615en01.pdf > (last accessed 20 October 2005).

${ }^{47}$ Robert O Keohane and Joseph S Nye Jr "Introduction" in Joseph S Nye and John D Donahue (eds) Governance in a Globalising World (Visions of Governance for the 21st Century, Cambridge (Mass), 2000) 1, 12 ["Introduction"].

${ }^{48}$ Roderick Rhodes "The New Governance: Governing Without Government" (1996) 44 Political Studies, 652, 653 ["The New Governance: Governing Without Government"].

${ }^{49}$ R A W Rhodes Understanding Governance: Policy Networks, Governance, Reflexivity and Accountability (Open University Press, Buckingham, 1997) 15 (emphasis in original).

50 "The New Governance: Governing Without Government", above n 48, 653. See also J N Rosenau "Citizenship in a Changing Global Order" in Rosenau and Czempiel (eds) Governance
} 
The Commission on Global Governance (CGG), a United Nations (UN) sponsored body designed specifically to look at global governance issues, has defined governance as: ${ }^{51}$

[T] he sum of the many ways individuals and institutions, public and private, manage their common affairs. It is a continuing process through which conflicting or diverse interests may be accommodated and co-operative action may be taken. It includes formal institutions and regimes empowered to enforce compliance as well as informal arrangements that people and institutions either have agreed to or perceive to be in their interest.

It is helpful to clarify the meanings and inter-relations of the words "institution" 52 and "regime" 53 in the perspective of governance, as these words shall frequently be used in the following sections. The connection among the three is that regimes are parts of governance systems, which are in turn institutions, as revealed from the following: ${ }^{54}$

\begin{abstract}
[A]n institution is a set of rules or conventions (both formal and informal) that define a social practice, assign roles to individual participants in the practice, and guide interactions among the occupants of these roles. A governance system is an institution that specializes in making collective choices on matters of common concern to the members of a distinct social group.... [A] regime is a governance system intended to deal with a more limited set of issues or a single issue area.
\end{abstract}

Though a uniform definition of governance does not exist, its use is noticed mostly in the concept of a global order, "as a portmanteau term for institutions and practices that are favourable to peace and development." Though there are disparities in definitional focus, the one thing that is established quite clearly is that governance is about processes and not just ends or

without Government: Order and Change in World Politics (Cambridge University Press, Cambridge, 1992) 291.

${ }^{51}$ Commission on Global Governance Our Global Neighbourhood (Oxford University Press, Oxford, 1995) 2 [Our Global Neighbourhood].

${ }^{52}$ For a discussion on the institutional framework for oceans governance, see Alf Hakon Hoel, Are K Sydnes and Syma A Ebbin "Ocean Governance and Institutional Change" in Syma A Ebbin, Alf Hakon Hoel and Are K Sydnes (eds) A Sea Change: The Exclusive Economic Zone and Governance Institutions for Living Marine Resources (Springer, Dordrecht, 2005) 3.

${ }^{53}$ For a discussion on the institutions within the EEZ regime, see Are K Sydnes, Alf Hakon Hoel and Syma A Ebbin "Changing Seas, Changing Institutions: Charting New Courses into the Future" in Syma A Ebbin, Alf Hakon Hoel and Are K Sydnes (eds) A Sea Change: The Exclusive Economic Zone and Governance Institutions for Living Marine Resources (Springer, Dordrecht, 2005) 210.

${ }^{54}$ International Governance: Protecting the Environment in a Stateless Society, above n 7, 26.

${ }^{55}$ Pierre de Senarclens "Governance and the Crisis in the International Mechanisms of Regulation” (1998) 155 International Social Science Journal 91, 92. 
outcomes. ${ }^{56}$ On the point of outcomes, it is observed that governance models seek to create stability. Further, governance is related to notions of order and decision-making. ${ }^{57}$ There is also a sort of consensus to be drawn with regard to the basic criteria of effectiveness of governance structures - effectiveness in managing a particular issue, in resolution of a problem and in the accommodation of multiple interests. ${ }^{58}$ Therefore, in sum, it can be said that there are five characteristics that most governance definitions embrace - (i) robust institutions for common good, (ii) rules, policies, processes and powers, (iii) effective implementation, enforcement, exercise and problem solving (iv) stability and performance and ( $\mathrm{v}$ ) good decision making in consideration of diverse interests.

\section{DEFINING OCEANS GOVERNANCE}

The need for oceans governance was put in perspective in the chapter 1, and the discussion must now continue with an explanation of what it means. This part deals with the meaning of oceans governance and gives what may be called a seagull's eye view of the various factors that contribute to it. Oceans governance is a term that is increasingly used in academic literature and in common parlance but, being a term with multiple dimensions, is not easy to define. $^{59}$

\footnotetext{
${ }^{56}$ Sakiko Fukuda-Parr and Richard Ponzio "Governance: Past, Present and Future - Setting the Governance Agenda for the Millennium Declaration" $<\mathrm{http}: / /$ www.undp.org/governance/docsaccount/gov-past-present-future.pdf $>$ (last accessed 20 October 2005) 2.

${ }^{57}$ Kimon Valaskakis "Long-term Trends in Global Governance: From 'Westphalia' to 'Seattle", in Governance in the 21st Century (Organisation for Economic Co-operation and Development, Paris, 2001) 45, 46.

${ }_{58}$ Marie-Claude Smouts "The Proper Use of Governance in International Relations" (1998) 155 International Social Science Journal 81, 88.

${ }^{59}$ Gilles Paquet and Kevin Wilkins Ocean Governance: An Inquiry into Stakeholding (Centre on Governance, University of Ottawa, Ottawa, 2002) cited in David VanderZwaag, Sean LeRoy and Rod Dobell "Ocean Governance" in Workshop Backgrounders: 2003 OMRN Conference (Ottawa, 2003) 1, available at $<\mathrm{http}: / / \mathrm{www}$. maritimeawards.ca/OMRN/vanderzwaag.pdf $>$ (last accessed 15 November 2005).
} 
One author defines the scope of oceans governance simply as the process of controlling the negative effect of human actions that affect the oceans. ${ }^{60}$ Robert Friedheim defined global oceans governance as: ${ }^{61}$

[T] he development of a set of ocean rules and practices that are equitable, efficient in the allocation of ocean uses and resources (including the notion of sustainability), provide the means of resolving conflicts over access to and the enjoyment of the benefits of the oceans, and specifically attempt to alleviate 'collective-action problems in a world of independent actors'.

Others have suggested that oceans governance refers to the ongoing evolution towards more "participatory decision-making" and suggests a variety of approaches to influence human behaviour towards the oceans. ${ }^{62}$ Another excellent definition of oceans governance is: ${ }^{63}$

\begin{abstract}
The term "ocean governance" covers a set of rules - some legally binding and some not - adopted by the international community of States ... for the structured regulation, management and control of ocean uses. It also includes the persons, bodies and institutions entrusted with administering the rules that govern ocean space. One of the purposes of ocean governance is the conservation of and protection of ocean habitat and marine life.
\end{abstract}

Oceans governance is indeed directed to control human action with respect to the oceans. Broadly, it can be argued that oceans governance is directed at ensuring that human needs from the oceans are met most sustainably as well as preserving the health of the oceans environment - living and nonliving. In other words, the concept of oceans governance ideally embraces the human elements ${ }^{64}$ of ocean uses along with the environmental aspects ${ }^{65}$ of the oceans.

\footnotetext{
${ }^{60}$ Susan Elliott Miller "Environmental Considerations in Hawaii Ocean Governance" in Thomas A Mensah (Program Chairman) Ocean Governance for Hawaii (No 3, Special Publication, Law of the Sea Institute, Honolulu, 1995) 115, 115 (emphasis in original).

${ }^{61}$ Robert L Friedheim "A Proper Order for the Oceans: An Agenda for the New Century" in Davor Vidas and Willy Østreng Order for the Oceans at the Turn of the Century (Kluwer Law International, The Hague, 1999) 537, 537. For a later version of Friedheim's arguments, see Robert L Friedheim "Ocean Governance at the Millennium: Where We Have Been - Where We Should Go" (1999) 42 Ocean \& Coastal Management 747.

${ }^{62}$ VanderZwaag, LeRoy and Dobell, above n 59, 1.

${ }^{63}$ Montserrat Gorina-Ysern, Kristina Gjerde and Michael Orbach "Ocean Governance: A New Ethos through a World Ocean Public Trust" in Linda K Glover and Sylvia A Earle (eds) Defying Ocean's End: An Agenda for Action (Island Press, Washington DC, 2004) 197, 198.

${ }^{64}$ For a detailed discussion on the human focus of governance, see generally Richard Falk On Humane Governance: Toward a New Global Politics (Pennsylvania State University Press, Pennsylvania, 1995).
} 
Though governance actions are primarily anthropocentric, it is submitted that intrinsic value of the environment ${ }^{66}$ independent of human interest is also recognised in oceans governance actions. Borgese had divided the economic value of the oceans into two parts - the human aspects that can be measured in terms of money by the quantifiable goods and services derived from the oceans, and the ocean's "ecosystem services" that is "non-quantifiable and nonmonetarizable." ${ }^{, 77}$ Also deserving of attention is the fact that often the seeming divisions between the different motives behind oceans governance initiatives are unclear. For instance, present oceans governance efforts are directed against preventing incidents of illegal, unreported and unregulated (IUU) fishing not only because they directly defeat conservation efforts and deplete fishery stocks, but also because in endangering fisheries they threaten human livelihoods dependent upon legally exploiting such fisheries. ${ }^{68}$

Within the structure of oceans governance lie other sub-regimes such as that of fisheries governance. Since fisheries governance comprises a large part of the greater oceans governance structure, and "reflects in a general way the issues embedded in all other uses of the ocean because [it] ... is concerned with managing the use and performance of a complex, dynamic, publicly owned resource,"69 a definition of fisheries governance could also help in the understanding of oceans governance. Serge Garcia defines fisheries governance as: ${ }^{70}$

\footnotetext{
${ }^{65}$ For a discussion on environmental focus of governance, see generally Maritta R v B KochWeser "Sustaining Global Environmental Governance: Innovation in Environment and Development Finance" Daniel C Esty and Maria H Ivanova (eds) Global Environmental Governance: Options \& Opportunities (Yale School of Forestry \& Environmental Studies, New Haven, 2002) 141. For a discussion on the environmental provisions of the LOSC, see Patricia Birnie "The Challenges of Applying UNCLOS in a Post UNCED Context" in Joseph J Norton, Mads Andenas and Mary Footer (eds) The Changing World of International Law in the TwentyFirst Century: A Tribute to the Late Kenneth $R$ Simmonds (Kluwer Law International, The Hague, 1997) 3, $11-28$.

${ }^{66}$ See Leena Vilkka The Intrinsic Value of Nature (Rodopi, Amsterdam, 1997).

${ }^{67}$ Elisabeth Mann Borgese "The Economics of the Common Heritage" (2000) 43 Ocean \& Coastal Management 766, $774-775$.

${ }^{68}$ For an interesting comment on oceans governance and fisheries, see Edward H Allison "Big Laws, Small Catches: Global Ocean Governance and the Fisheries Crisis" (2001) 13 J Int Dev 933.

${ }^{69}$ Susan S Hanna "Strengthening Governance of Ocean Fishery Resources" (1999) 31 Ecological Economics 275, 278.

${ }^{70}$ Serge Garcia "Fisheries Governance" $<$ http://www.oceansatlas.org $>$ (last accessed 1 November 2005).
} 
[T]he sum of the legal, social, economic and political arrangements used to manage fisheries, [that] has international, national and local dimensions. It includes legally binding rules, such as national legislation or international treaties, and it relies on customary social arrangements as well as on the respective national framework provided for all economic activities.

It is found that oceans governance involves crossovers between many ecological $^{71}$ and environmental boundaries as well as across various jurisdictions. $^{72}$

Adalberto Vallega in discussing oceans governance asserts that the word 'governance' places great emphasis on the importance of human strategies and actions with regard to the oceans and the role of integrated political approaches. $^{73}$ According to Vallega, the word 'governance' has its root in the Greek word 'kybernan' - meaning, "to hold the reign." 74 It is a coincidence that the word 'governance' forming a part of the expression 'oceans governance' has its roots in navigation and originally meant conducting a structure or an organisation system, like a vessel, towards a certain target. ${ }^{75}$ Vallega argues that oceans governance focuses on the organisational systems, considers them as a whole and aims at systematically valuing the consistency of the overall organisation with the goals to be achieved, and the targets to be proceeded towards. $^{76}$

Without reading too much into the details of the connotation of words and expressions, oceans governance could be said to signify ocean use management across a range of interests. Oceans governance has come a long way from the days of Hugo Grotius to the present, marking a constant process of evolution of legal arrangements for governing oceans as attempts are made to accommodate new imperatives. ${ }^{77}$ Indeed, the oceans have come to be associated with a variety

\footnotetext{
71 See Adalberto Vallega Sustainable Ocean Governance: A Geographical Perspective (Routledge, London, 2001) 20 [Sustainable Ocean Governance].

72 Katheryn J Mengerink "The Pew Ocean Commission Report: Navigating a Route to Sustainable Seas” (2004) 31 Ecology L Q 689, 694.

${ }^{73}$ Adalberto Vallega "Ocean Governance in Post-modern Society - A Geographical Perspective" (2001) 25 Marine Policy 399, 399 [“Ocean Management in Post-modern Society”].

74 "Ocean Management in Post-modern Society", above n 73, 399.

${ }^{75}$ See "Ocean Management in Post-modern Society", above n 73, 399.

76 "Ocean Management in Post-modern Society", above n 73, 399.

${ }^{77}$ For a comprehensive examination and analysis of the evolving structure of oceans governance in an international law setting, see Lawrence Juda International Law and Ocean Use Management: The Evolution of Ocean Governance (Routledge, London, 1996) [International Law and Ocean Use Management]. See also Ram Prakash Anand "Freedom of the Seas: Past, Present and Future" in Rafael Gutiérrez Girardot and others (eds) New Directions In
} 
of expressions symbolising the attitude of humankind towards its governance at any given point in time. In 1609, the Dutch jurist, Hugo Grotius developed the concept of mare liberum ${ }^{78}$ in a commentary that promulgated the idea of the freedom of the seas. ${ }^{79}$ This was strongly challenged by the English scholar, John Selden, in 1635 with his own theory of mare clausum, ${ }^{80}$ in which he expounded inter alia that the ocean space could be appropriated under certain circumstances and that marine resources were not inexhaustible. ${ }^{81}$ Today, there are advocates arguing for relatively new, though debatable, oceans governance principles like mare nostrum ${ }^{82}$ and mare reservarum. ${ }^{83}$

Oran Young, an authoritative writer on governance structures of international regimes, notes that regimes should not be thought of as "rigid and unchanging structures whose existence is somehow separate from ongoing political and economic interactions within the relevant social structure." ${ }^{84}$ Not

International Law: Essays in Honour of Wolfgang Abendroth (Campus Verlag, New York, 1982) 215; Peter Jacques and Zachary A Smith Ocean Politics and Policy: A Reference Handbook (ABC-CLIO Inc, Santa Barbara, California, 2003) 1 - 18. See also Francisco Orrego Vicuña "Coastal States' Competences over High Seas Fisheries and the Changing Role of International Law" (1995) 55/2 ZaöRV 520; John Kurien Property Rights, Management and Governance: Crafting an Institutional Framework for Global Marine Fisheries (Centre for Development Studies and South Indian Federation of Fishermen Societies, Thiruvananthapuram, 1998) 17 - 28. ${ }^{78}$ Hugo Grotius The Freedom of the Seas or The Right which Belongs to the Dutch to Take Part in the East Indian Trade (Translated with a Revision of the Latin Text of 1633 by Ralph van Deman Magoffin, Edited with an Introductory Note by James Brown Scott, Oxford University Press, New York, 1916, Reprint, Lawbook Exchange, Clark (New Jersey), 2001).

${ }^{79}$ Ram Prakash Anand Origin and Development of the Law of the Sea: History of International Law Revisited (Martinus Nijhoff Publishers, The Hague, 1982) 77 [Origin and Development of the Law of the Sea]. On the freedom of the seas, see W Paul Gormley "The Development and Subsequent Influence of the Roam Legal Norm of 'Freedom of the Seas" (1963) 40 U Det L J 561.

${ }^{80}$ John Selden Of the Dominion, or, Ownership of the Sea. Two Books: In the First, is Shew'd that the Sea, by the Law of Nature, or Nations, is Not Common to All Men but Capable of Private Dominion or Proprietie as well as the Land in the Second, is Proved That the Dominion of the British Sea, or That Which Incompasseth the Isle of Great Britain, is, and Ever Hath Been, a Part or Appendant of the Empire of that Island. Written at First in Latin and Entitled Mare Clausum, Seu, De Dominio Maris (Translated into English and set forth with some additional evidences and discourses by Marchmont Nedham, Lawbook Exchange, Clark (New Jersey), 2003).

${ }^{81}$ Origin and Development of the Law of the Sea, above n 79, 105.

${ }^{82}$ Phillip Allott "Mare Nostrum: A New International Law" in Jon M Van Dyke, Durwood Zaelke and Grant Hewison (eds) Freedom for the Seas in the 21st Century: Ocean Governance and Environmental Harmony (Island Press, Washington DC, 1993) 49.

${ }^{83}$ Garry R Russ and Dirk C Zeller "From Mare Liberum to Mare Reservarum" (2003) 27 (1) Marine Policy 75, 77. See also Dirk Zeller "From Mare Liberum to Mare Reservarum: Canada's Opportunity for Global Leadership in Ocean Resource Governance" (2005) 19 Ocean Yearbook 1,11 .

${ }^{84}$ Oran Young Resource Management at the International Level: The Case of the North Pacific (Frances Printer, London, 1977) 46 [Resource Management at the International Level]. 
surprisingly, the regime ${ }^{85}$ of oceans governance is also affected by this phenomena of constant change and evolution. With the passage of time, oncegoverning principles of the law of the sea become outdated faced with changing scenarios of politics, economics, society and technology. ${ }^{86}$ Thus the structure of oceans governance undergoes a change with the amendments in the legal and management structures taking place under new conditions and newly perceived needs set in a complex web of interactions between human and environmental factors. $^{87}$

The workshop led by IWCO on sustainable oceans governance resulted in the recognition of six principles called the Lisbon Principles of Sustainable Governance (LPSG), that are necessary for present day oceans governance: responsibility, scale-matching, precaution, adaptive management, full cost allocation and participation. ${ }^{88}$ The experts at the workshop concluded, “.... any attempts to achieve 'globally optimal' ocean governance policies are chimeras." 89 In the same vein, Johnston opines that the idea of oceans governance is an idealistic expression "if it conveys the hope that all ocean uses and users can be made subject to reasonable considerations of equity and rational concepts of efficiency or effectiveness. ${ }^{90}$ Borgese has made similar comments about oceans governance, which has been consistently evolving for over the past three decades, but is an ongoing "process which will go on and never be completed." 91

\footnotetext{
85 " $[\mathrm{A}]$ regime is a set of agreements among some specified group of actors spelling out: 1) a well-defined distribution of power and authority for the relevant social structure or geographical region, 2) a system of rights and liability rules for the members of the social structure, and 3) a collection of behavioral prescriptions or rules which indicate actions the members are expected to take under various circumstances." Resource Management at the International Level, above n 84, 45.

${ }^{86}$ See International Law and Ocean Use Management, above $\mathrm{n} 77$, 3. See also Myres $\mathrm{S}$ McDougal and Norbert A Schlei "The Hydrogen Bomb Tests in Perspective: Lawful Measures for Security" (1954-1955) 64 Yale L J 648, 656.

${ }^{87}$ See International Law and Ocean Use Management, above n 77, 3. See generally Juan Luis Suarez de Vivero and Juan Carlos Rodriguez Mateos "New Factors in Ocean Governance: From Economic to Security-Based Boundaries" (2004) 28 Marine Policy 185, 187.

${ }^{88}$ Robert Constanza and others "Ecological Economics and Sustainable Governance of the Oceans" (1999) 31 Ecological Economics 171, 172 ["Ecological Economics and Sustainable Governance of the Oceans"].

89 "Ecological Economics and Sustainable Governance of the Oceans", above n 88, 186.

${ }^{90}$ Douglas M Johnston, "Ocean Governance: Converging Modes of Idealism" in Jon M Van Dyke, Durwood Zaelke and Grant Hewison (eds) Freedom for the Seas in the 21st Century: Ocean Governance and Environmental Harmony (Island Press, Washington DC, 1993) 471, 471.

${ }^{91}$ The Oceanic Circle: Governing the Seas as a Global Resource, above n 3, 197.
} 
In author's opinion, the observations of eminent commentators on the idealism and never-ending nature of oceans governance, have considerable merit. It is true that oceans governance on one part is a constantly evolving process and demands direction and action attuned to ever-changing circumstances. Oceans governance embraces the need to have shifting goalposts to meet diverse needs and considerations in equally varied geographical and jurisdictional conditions. However, considerations such as those of optimality, equity, efficiency or effectiveness are subjective and thus, the conception of an idea of oceans governance based on subjective considerations is bound to appear elusive. Oceans governance in this light is an ongoing endeavour and there is hope in the suggestion that efforts designed along the lines of the LPSG could bring forth oceans governance that is "inclusive, inquisitive, careful, fair, scale-sensitive, and adaptive." 92

In sum, oceans governance can be described as a chosen course of collective action that follows a given set of goals and identifies tools and mechanisms to steer it towards those goals. ${ }^{93}$ Broadly, oceans governance can be called both a process and an outcome involving (i) rules to secure human needs from the oceans and to protect and preserve the living and non-living marine environment, (ii) organisational and implementation systems and institutions, (iii) provisions to settle disputes over access to and control over ocean resources and space, and (iv) many jurisdictional and ecological boundaries in an everchanging matrix of political, economic, social and environmental factors.

\section{LAW, DISPUTE SETTLEMENT AND GOVERNANCE}

The aim of this section is to seek out the links between law, dispute settlement and governance. The general literature on dispute settlement and governance ${ }^{94}$ presently analysed here, provides insights into a discussion about the role of dispute settlement in oceans governance in part IV.

\footnotetext{
92 "Ecological Economics and Sustainable Governance of the Oceans", above n 88, 186.

${ }^{93}$ See generally James N Rosenau "Governance in the Twenty-first Century" (1995) 1 Global Governance 13,14.

${ }^{94}$ For a literature review on the links between governance and dispute settlement, see United Nations Development Programme "Promoting Conflict Prevention and Conflict Resolution Through Effective Governance: A Conceptual Study and Literature Review" $<$ http://magnet.undp.org/Docs/crisis/mapexercise.htm $>$ (last accessed 20 October 2005).
} 
Law finds a prominent place in the process of governance. Lawrence Lessig argues that laws, norms, markets and architecture are all instrumental in accomplishing governance. ${ }^{95}$ Young finds a role for legal regimes along with non-legal regimes such as political, social and economic arrangements, in governance systems. ${ }^{96}$ Elinor Ostrom claims that the presence of conflict resolution mechanisms are an integral part of making institutions involved in the governance of common pool resources truly robust in performance. ${ }^{97}$

According to the European Commission, governance is an institutional affair and refers to the exercise of power and connotes actions by executive bodies, assemblies and judicial bodies. ${ }^{98}$ Therefore, it is seen that judicial bodies such as courts and tribunals fall within the arena of institutions that play a role in the governance process. ${ }^{99}$ The World Bank also considers judicial and legal systems to be essential to governance. According to it, good governance involves inter alia - “... an independent judicial system and legal framework to enforce contracts ... [and] respect for the law ... at all levels of the government ..." ${ }^{100}$ As is obvious from the definition, the importance of the legal framework and the machinery available to enforce laws is quite high in achieving good governance. On the point of the governance process, it has been argued elsewhere that since a process is hard to observe, the attention needs to be drawn towards agreements, procedures, conventions and policies forming the framework on which the governance process rests. ${ }^{101}$ Since conventions and agreements that are legally executed have the force of the law and are often capable of enforcement through judicial and non-judicial means of dispute settlement, the link between law, dispute settlement and governance is apparent.

\footnotetext{
${ }^{95}$ Lawrence Lessig Code and Other Laws of Cyberspace (Basic Books, New York, 1999) 88.

${ }^{96}$ See International Governance: Protecting the Environment in a Stateless Society, above n 7, 185.

${ }^{97}$ Elinor Ostrom Governing the Commons: The Evolution of Institutions for Collective Action (Cambridge University Press, New York, 1990) 181.

98 European "What Commission Governance?" $<\mathrm{http}$ ://europa.eu.int/comm/governance/index_en.htm> (last accessed 20 October 2005).

${ }^{99}$ Hazel Henderson "New Markets and New Commons" (1995) 27 (2) Futures 113, 117.

${ }^{100}$ The World Bank Governance and Development (The World Bank, Washington DC, 1992).

${ }^{101}$ John Graham, Bruce Amos and Tim Plumptre "Principles of Good Governance in the 21st Century" (2003) Policy Brief No 15, Institute on Governance $<\mathrm{http}$ ://www.iog.ca/publications/policybrief15.pdf $>$ (last accessed 25 October 2005).
} 
Another author has argued that international law plays an important role in global governance by norm generation and enforcement. ${ }^{102}$ A natural question at this point needs to be addressed: what is the relevance of international law to dispute settlement? Richard Bilder, a distinguished authority in the field of international dispute settlement, answers the question satisfactorily. ${ }^{103}$ First, he argues that it is one of the key tenets of international law that disputes should be settled peacefully; secondly, the international legal system establishes norms and procedures alongside a variety of formal and informal institutions that aid in dispute avoidance in general and its settlement on arising; and finally international agreements provide mechanisms through which nations are able to commit themselves to the principle of peaceful settlement of disputes by establishing methods for resolving disputes peacefully. ${ }^{104}$

Among its many conclusions, the CGG opines that creation of effective governance mechanisms demands inter alia the improvement of "the capacity for the peaceful resolution of disputes." 105 However, the CGG also adds that on most occasions international law performs well on its own without resort to dispute settlement mechanisms, and there have been times when international law has failed to resolve disputes. ${ }^{106}$ The reason provided for this phenomenon is that international standards are often self-enforced through a general social pressure for compliance created by the combined actions of states, international institutions and civil society. ${ }^{107}$ Nevertheless, the CGG concludes that international law could be strengthened by widespread acceptance of compulsory jurisdiction of international tribunals such as the International Court of Justice (ICJ). ${ }^{108}$ This would be one way of advancing the cause of good global governance. One of the most important requirements of global governance is the rule of law - the shared understanding that international laws, rules and norms

\footnotetext{
${ }^{102}$ David Kennedy "New Approaches to Comparative Law: Comparativism and International Governance" (1997) 1997 Utah L Rev 545, 551 - 552. For a discourse on the legalisation of global governance under the WTO's Appellate Body, see Sol Picciotto "The WTO's Appellate Body: Legal Formalism as Legitimation of Global Governance" (2005) 18 (3) Governance 477, 477.

${ }^{103}$ Richard B Bilder "An Overview of International Dispute Settlement" (1986) 1 Emory J Intl Dispute Res 1, 31 ["An Overview of International Dispute Settlement"].

104 "An Overview of International Dispute Settlement", above n 103, 31.

${ }^{105}$ Our Global Neighbourhood, above n 51, 5.

${ }^{106}$ Our Global Neighbourhood, above n 51, 304.

${ }^{107}$ Our Global Neighbourhood, above n 51, 305.

${ }^{108}$ Our Global Neighbourhood, above n 51, 308 - 309.
} 
are for all states to abide by, weak or powerful. ${ }^{109}$ It has been argued that, in the absence of such compulsory jurisdiction, there is a growth in political manoeuvring and the danger of unilateral interpretation of the law, leading to situations of disturbed peace and security. ${ }^{110}$

Nzongola-Ntalaja concludes that good governance processes are unable to effectively function under situations of violent conflict and disturbed peace. ${ }^{111}$ This is yet another perspective on the way in which dispute settlement mechanisms find a role to play in good governance. An expanding role for dispute settlement mechanisms has been noticed in global governance particularly in the case of investments, trade and other forms of economic cooperation. ${ }^{112}$ Vicuña has argued that such an enlarged role for international dispute settlement involving private individuals' access is a consequence of globalisation. ${ }^{113}$ It is submitted that the field of oceans governance is no exception to this trend with private individuals and corporations having the right to access ITLOS under certain circumstances. ${ }^{114}$

Some commentators have expressly cast doubts on whether international law $^{115}$ and formal dispute settlement procedures are required for governance ${ }^{116}$ or have simply refused to acknowledge or give due regard to their role in governance. ${ }^{117}$ Though dispute settlement mechanisms may potentially have a

\footnotetext{
109 Our Global Neighbourhood, above n 51, 332. See also Michael Carley and Ian Christie "The World's Commons: The Challenge of Governance" in Governance for a Sustainable Future: Reports of the Commissions of World Humanity Action Trust (World Humanity Action Trust, London, 2000) 29.

${ }^{110}$ See Our Global Neighbourhood, above 51, 309.

${ }^{111}$ Georges Nzongola-Ntalaja "Good Governance and Conflict Management: Will the African Union Make a Difference? in Forum Evening, CCM's Norwegian Peacebuilding Empowerment Programme (Oslo, 2002) 8.

${ }^{112}$ See Francisco Orrego Vicuña International Dispute Settlement in an Evolving Global Society: Constitutionalization, Accessibility, Privatization (Cambridge University Press, Cambridge, 2004) 63 - 84 [International Dispute Settlement in an Evolving Global Society].

${ }^{113}$ International Dispute Settlement in an Evolving Global Society, above n 112, 63 - 84.

${ }^{114}$ See Tullio Treves "The Jurisdiction of the International Tribunal for the Law of the Sea" in P Chandrasekhara Rao and Rahmatullah Khan (eds) International Tribunal for the Law of the Sea: Law and Practice (Kluwer Law International, The Hague, 2001) 111, 113 - 114.

${ }^{115}$ Bradley Karkkainen "Marine Ecosystem Management \& a 'Post-Sovereign' Transboundary Governance" (2004) San Diego Intl L J 113, 113.

${ }^{116}$ See Oran Young International Cooperation: Building Regimes for Natural Resources and the Environment (Cornell University Press, Ithaca, 1989) 44 [International Cooperation]; Abram Chayes and Antonia Handler Chayes The New Sovereignty: Compliance with International Regulatory Agreements (Harvard University Press, Cambridge (Mass), 1995) 24.

117 See Jorgen Wettestad Designing Effective Environmental Regimes: The Key Conditions (Edward Elgar Publishing Limited, Cheltenham, 1995); David G Victor, Kal Raustiala and Eugene B Skolnikoff (eds) The Implementation and Effectiveness of International Environmental Commitments: Theory and Practice (The MIT Press, Cambridge (Mass), 1998).
} 
role to play in governance, that potential can fail to translate into reality if they are not utilised. In this regard, it is useful to enquire into the willingness of states to use dispute settlement mechanisms in the settlement of disputes. Young opines that countries that are willing to settle their disputes would anyway find a way to do so, but those that are unwilling to do so would be unwilling to accept the jurisdiction of a court or tribunal. ${ }^{118}$

Commentators have often pointed out that states are particularly reluctant to use formal dispute settlement procedures in settling disputes under environmental regimes. ${ }^{119}$ Authors have supplied a variety of reasons for such reluctance, ranging from - (i) the relative ease in settling disputes informally at much lower levels in meetings between government departments and secretariats, ${ }^{120}$ (ii) the apprehension of unwelcome precedents and implications for the claimant state and the world at large arising out of adjudication in the face of unsettled customary law, ${ }^{121}$ (iii) the supposed inappropriateness of using thirdparty adjudicatory dispute settlement bodies for settling disputes that are not based on real points of law but science, ${ }^{122}$ (iv) the unsuitability of settling environmental problems affecting common interests, common property or interests of future generations through a system of according rights to "injured states" using third-party dispute settlement, ${ }^{123}$ (v) the slowness and the burden of formal dispute settlement procedures, ${ }^{124}$ (vi) a fear that given the conservative bias of courts and legal systems, formal third-party dispute settlement processes would not lead to outcomes that are sufficiently "green"125, and (vii) the

\footnotetext{
${ }^{118}$ International Cooperation, above n 116, 44.

119 See International Cooperation, above n 116, 44. See generally International Institute for Sustainable Development "A Summary Report of the High-Level Meeting on Compliance with and Enforcement of Multilateral Environmental Agreements: 21 - 22 January 2006" (2006) available at $<$ http://www.iisd.ca/ymb/unepmea/> (last accessed 26 January 2006) 3, 5.

120 Edith Brown Weiss quoted in Gideon Rottem "Compliance with International Standards: Environmental Case Studies” (1995) 89 Am Socy Intl L Proc 206, 220.

121 Patricia W Birnie and Alan E Boyle International Law And The Environment (Oxford University Press, Oxford, 1992) 221.

122 Ellen Hey "Increasing Accountability for the Conservation and Sustainable Use of Biodiversity: A Question of Transnational Global Character" (1995) 6 Colo J Intl Envtl L \& Poly 1,2 , footnote 3 .

123 Alan E Boyle "Saving the World? Implementation and Enforcement of International Environmental Law Through international Institutions" (1991) 3 J Envtl L 229, 230.

${ }_{124}$ Robert Keohane quoted in Rottem, above n 120, 220.

125 Martti Koskenniemi "Peaceful Settlement of Environmental Disputes" (1991) 60 Nordic Journal of International Law 73, 82.
} 
undesirability of the recognition that states are in disagreement may affect concordance in other areas of the states' relations. ${ }^{126}$

Though all this may be true to a certain extent, given the consensual nature of international dispute settlement, the role of law and legal arrangements such as formal dispute settlement mechanisms cannot be ignored. As a detailed study by the United Nations Environment Programme (UNEP) ${ }^{127}$ has concluded, "[d]ispute settlement has long been a focus of inter-State relations, and it remains an important tool for dealing with international problems." ${ }^{128}$ Particularly, the allegation of slowness that is levelled against international dispute settlement procedures can be answered using the words of the international jurist, Manley Hudson. Hudson attributes the speed of progress in international dispute settlement as something of the parties' own making, stating - "the care which States will wish to bestow on the preparation of their contentions and the thoroughness with which deliberations ought to be conducted will not permit of hasty action by an international tribunal." 129 Besides, Birnie and Boyle also admit that international courts and tribunals play a greater role in the development of the law of the sea than of international environmental law. ${ }^{130}$ This point shall be addressed in detail in part IV.

The importance of law in global environmental governance has been stressed in the past. ${ }^{131}$ A number of commentators have also argued supporting the importance of dispute settlement mechanisms in international environmental law. ${ }^{132}$ Most of them argue that dispute settlement mechanisms play a vital role

\footnotetext{
${ }^{126}$ Cesare P R Romano The Peaceful Settlement of International Environmental Disputes - A Pragmatic Approach (Kluwer Law International, London, 2000) 44.

${ }^{127}$ UNEP "Study on Dispute Avoidance and Dispute Settlement in International Environmental Law" (19 January 1999) UNEP/GC.20/INF/16.

${ }^{128}$ International Group of Experts "Dispute Avoidance and Dispute Settlement in Internatinal Environmental Law - Conclusions by the International Group of Experts" (1999) 29 (2-3) Envtl Poly \& L 143, 143.

129 Manley O Hudson International Tribunals: Past and Future (Carnegie Endowment for International Peace and Brookings Institution, Washington DC, 1944) 237.

${ }^{130}$ Birnie and Boyle, above n 123, 221.

${ }^{131}$ See L F E Goldie "Development of an International Environmental Law - An Appraisal" in John Lawrence Hargrove (ed) Law, Institutions, and the Global Environment (Oceana Publications Inc, Dobbs Ferry (New York), 1972) 104. See generally Peter M Haas "UN Conferences and Constructive Governance of the Environment" (2002) 8 Global Governance 73.

${ }^{132}$ See Geoffrey Palmer "New Ways to Make International Environmental Law" (1992) 86 AJIL 259, 282 - 283; Richard Bilder "The Settlement of Disputes in the Field of International Law of the Environment" (1975) 44 Recueil des Cours 139, 154; Report of the Secretary General of the United Nations Conference on Environment and Development, para 152, reprinted in Nicholas A
} 
in the implementation of, compliance with, and enforcement of international law. ${ }^{133}$ It is also stressed that judicial modes of dispute settlement play an important part "in promoting environmental governance, upholding the rule of law and in ensuring a fair balance between environmental, social and developmental considerations through its [judgments] and declarations." ${ }^{134}$ In any case, the sparse use of dispute settlement procedures hardly suggests that they are not important to governance. As will be shown in chapter 5, the very availability of dispute settlement options is an important element of the governance.

Abbott and Snidal argue that hard law arrangements with legally binding obligations and formal dispute settlement mechanisms are popular in international governance as it helps states reduce transaction costs of enforcement, expand their political strategies, and resolve any problems arising out of ambiguities or a lack of clarity in agreements between states. ${ }^{135}$ They contend that the legalisation of governance constrains the opportunities for selfserving unilateral interpretation among states. ${ }^{136}$

Robinson (ed) Agenda 21 and the UNCED Proceedings (vol 2, Oceana Publications, New York, 1992) $733-734$.

${ }^{133}$ See Joost Pauwelyn "Judicial Mechanisms: Is there a Need for a World Environment Court?" in W Bradnee Chambers and Jessica F Green (eds) Reforming International Environmental Governance: From Institutional Limits to Innovative Reforms (United Nations University Press, Tokyo, 2005) 150; Alfred Rest "Enhanced Implementation of International Environmental Treaties by Judiciary - Access to Justice in International Environmental Law for Individuals and NGOs: Efficacious Enforcement by the Permanent Court of Arbitration" (2004) 1 MqJICEL 1, 9; Gerhard Loibl "Reporting and Information Systems in International Environmental Agreements as a Means of Dispute Prevention - The Role of 'International Institutions"' (2005) 5 Non-State Actors \& Intl L 1; Philippe Sands "Compliance with International Environmental Obligations: Existing International Legal Arrangements" in James Cameron, Jacob Werksman and Peter Roderick (eds) Improving Compliance with International Environmental Law (Earthscan Publications Ltd, London, 1996) 48, 81; Rüdiger Wolfrum "Means of Ensuring Compliance with and Enforcement of International Environmental Law" (1998) 272 Recueil des Cours 25, 96 100.

${ }^{134}$ Klaus Toepfer "Message" in United Nations Environment Programme UNEP Global Judges Programme (United Nations Environment Programme, Nairobi, 2005) v. For a brief report on the role of the international judicial systems in the settlement of international environmental disputes, see UNEP/UNDP Joint Project on Environmental Law and Institutions in Africa Compendium of Judicial Decisions on Matters Related to Environment - International Decisions (vol 1, United Nations Environment Programme, Nairobi, 1998).

${ }^{135}$ Kenneth W Abbott and Duncan Snidal "Hard and Soft Law in International Governance" (2000) 54 (3) International Organization 421, 422.

${ }^{136}$ Abbott and Snidal, above n 135, 427; Jack L Goldsmith and Eric A Posner The Limits of International Law (Oxford University Press, Oxford, 2005) 83. See generally Robert O Keohane, Andrew Moravcsik and Anne-Marie Slaughter "Legalized Dispute Resolution: Interstate and Transnational" (2000) 54 (3) Intl Org 457. 
An idea from the Tokyo Institute of Technology throws an interesting light on the connection between governance and the resolution of disputes. It is said that " $[t]$ he concept of governance refers to the complex set of values, norms, processes and institutions by which society manages its development and resolves conflict, formally and informally." 137 As is clear from the above words, the concept of conflict resolution thorough formal and informal means is embedded in the governance process.

In conclusion, it is generally observed that though the connection between law and governance is more or less well established the same cannot be said of the link between dispute settlement, particularly the formal procedures, and governance. Opinions are divided regarding the role of formal dispute settlement procedures in the governance process. Legal scholars are enthusiastic about formal dispute settlement procedures such as adjudication and arbitration, while social scientists advocate for more informal modes such as negotiation or mediation. ${ }^{138}$ Therefore, overall it is fair to surmise that law plays an important role in the governance process, and dispute settlement procedures, forming an important leg of legal systems also contribute to governance. Governance processes and outcomes derive considerable benefits from the rule of law protected by robust dispute settlement systems. ${ }^{139}$

\section{LAW, DISPUTE SETTLEMENT AND OCEANS GOVERNANCE}

This part explores and discusses the many possible links between law, dispute settlement and oceans governance. In particular, it focuses upon the possible roles that exist for dispute settlement in oceans governance. Here, the "private function" of dispute settlement is discussed - a function that primarily

\footnotetext{
137 Quoted in Weiss, above n 44, 797. For a similar study on the role of law and dispute settlement in good governance, see Asian Development Bank Law and Policy Reform at the Asian Development Bank - Legal Empowerment: Advancing Good Governance and Poverty Reduction (Office of the General Counsel, Asian Development Bank, Manila, 2001).

${ }^{138}$ Compare Shabtai Rosenne The World Court: What it is and How it Works $\left(5^{\text {th }}\right.$ ed, Martinus Nijhoff Publishers, Dordrecht, 1995) and Thomas C Schelling The Strategy of Conflict (Harvard University Press, Cambridge (Mass), 1960).

${ }^{139}$ See Lal Kurukulasuriya "The Role of the Judiciary in Promoting Environmental Governance and the Rule of Law" in Global Environmental Governance: The Post-Johannesburg Agenda (Yale Centre for Environmental Law and Policy, New Haven, 2003) available at $<$ http://www.yale.edu/gegdialogue/docs/dialogue/oct03/papers/Kurukulasuriya\%20final.pdf $>$ (last accessed 6 December 2005). See also Dinah Shelton and Alexandre Kiss Judicial Handbook on Environmental Law (United Nations Environment Programme, Nairobi, 2005) 43.
} 
aims at simply settling a dispute between two parties. The "public functions" 140 of dispute settlement that serve wider ends of oceans governance, are also analysed here. In the later sections of this part, some of the other "public functions" of dispute settlement are individually analysed.

The author believes that dispute settlement procedures largely have a real and positive role to play in oceans governance, though they may at times even have a detrimental effect too. As an illustration, Richard McLaughlin has shown that the Tuna/ Dolphin Decision ${ }^{141}$ by a dispute resolution panel under the General Agreement on Tariffs and Trade (GATT) ${ }^{142}$ potentially undermined oceans governance strategies in the United States. ${ }^{143}$ Just like the GATT dispute resolution panel, the LOSC dispute settlement processes could and arguably have at times had a detrimental impact on oceans governance, as will be seen in chapter 3. However, this part shall focus on the scope and potential of the LOSC dispute settlement mechanisms to have a beneficial influence on oceans governance.

To begin a detailed argument in this regard, it must be recognised that dispute settlement procedures "cannot be successfully used nor interestingly discussed without regard to the types of outcomes it is intended, or likely to produce." 144 This is justified perhaps because, as Owen Fiss observes, dispute settlement procedures serve as a vehicle for a society to transform its chosen ideals into reality. ${ }^{145}$ Therefore in understanding the reason behind the establishment of dispute settlement procedures in the LOSC, one might enquire as to whether its involvement in oceans governance was intended during its drafting process and if so, to what extent.

The later half of the twentieth century witnessed a significant increase in the number and types of inter-state disputes concerning the uses of oceans. ${ }^{146}$

\footnotetext{
${ }^{140}$ See A Neil Craik "Recalcitrant Reality and Chosen Ideals: The Public Function of Dispute Settlement in International Environmental Law" (1998) 10 Geo Intl Envtl L Rev 551, 576.

${ }^{141}$ United States - Restrictions on Imports of Tuna - Report of the GATT Panel (16 August 1991) DS21/R; (1991) 30 ILM 1598.

${ }_{142}^{14}$ General Agreement on Tariffs and Trade (30 October 1947) 55 UNTS 194.

143 Richard J McLaughlin "Free Trade, GATT, and Ocean Governance" (1994) 23 Ocean \& Coastal Management 65, $72-78$.

${ }^{144}$ Koskenniemi, above n 125, 74 .

145 Owen M Fiss “Against Settlement” (1984) 93 Yale L J 1073, 1089.

${ }^{146}$ For a informative account on the nature of maritime disputes and brief description of the main disputes so far, see Ted L McDorman and Aldo Chircop "The Resolution of Maritime Disputes"
} 
The increasing uses being found for the oceans, often leading to dispute situations and the failure of the past global attempts in producing a universally accepted and codified set of laws for oceans governance, paved the way for UNCLOS III that produced the LOSC. ${ }^{147}$ Donald Watt said in 1979: ${ }^{148}$

\begin{abstract}
The seas can be managed perhaps; but never directed. But management implies care, control and the resolution of the conflict between the many uses and demands we need to make of it. ... The ocean seems likely to become the most conflict-prone sector of our planet; the conflicts will be about resources; and they will take place at all levels, from the local to the super-power.
\end{abstract}

The nature and extent of the possible conflicts have gone well beyond the destruction of species by over-fishing ${ }^{149}$ and that of coastlines through pollution, as envisaged by Watt. In light of the increasing number and quality of ocean disputes and conflict situations, the possible role for much needed dispute settlement options was not hard to imagine.

One of the primary reasons for the incorporation of dispute settlement provisions in the LOSC was to prevent unilateral interpretations of the treaty provisions by states. ${ }^{150}$ During the fourth session of UNCLOS III, Hamilton Shirley Amerasinghe, the President of the Conference, summed up the need for having effective dispute settlement procedures in the following words: ${ }^{151}$

\begin{abstract}
[T] he provision of effective dispute settlement procedures is essential for stabilizing and maintaining the compromises necessary for the attainment of agreement on a convention ... [and d]ispute settlement procedures will be the pivot upon which the delicate equilibrium of the compromise must be balanced. Otherwise the compromise will disintegrate rapidly and permanently ... Effective dispute settlement would also be the guarantee that the substance and intention within the legislative language of the convention will be interpreted both consistently and equitably.
\end{abstract}

\footnotetext{
in Edgar Gold (ed) Maritime Affairs: A World Handbook (Longman Group UK, Harlow, Essex, 1991) $344-386$.

${ }^{147}$ See Alan Boyle "Further Development of the Law of the Sea Convention: Mechanisms for Change" (2005) 54 ICLQ 563, 563.

${ }_{148}$ Donald Cameron Watt The Future Governance of the Seas: An Inaugural Lecture for the Inauguration of the M Sc Course in Sea Use: Law, Economics and Policy - Making (The London School of Economics and Political Science, London, 10 October 1979) 5 and 10.

${ }^{149}$ See generally Tim Eichenberg and Mitchell Shapson "The Promise of Johannesburg: Fisheries and the World Summit on Sustainable Development" (2004) 34 Golden Gate U L Rev 587, 596.

${ }^{150}$ Louis B Sohn "The Importance of the Peaceful Settlement of Disputes Provisions of the United Nations Convention on the Law of the Sea" in M H Nordquist and J N Moore (eds) Entry into Force of the Law of the Sea Convention (Martinus Nijhoff Publishers, The Hague, 1995) 265, 265 ["The Importance of the Peaceful Settlement of Disputes Provisions"].

${ }^{151}$ UN Doc A/CONF.62/WP.9/ADD.1, Off. Rec. V, 122 (President).
} 
The issue of the possibility for unilateral interpretation of the Convention had begun to raise questions as to the basic incentive of states to even ratify it. It was realised that dispute settlement in the Convention was not merely a peripheral matter of procedure but was indeed substantive, protecting the rights and freedoms that were being given the force of law. ${ }^{152}$ In this regard, it was said that: ${ }^{153}$

If states cannot resort to international adjudicatory procedures to protect their rights, they are ultimately faced with the same problems arising from unilateral treaty interpretation that arise from unilateral claims. If their own interests are not adequately protected, what then is the incentive for states to accept a treaty that will inevitably contain rules designed to accommodate interests they do not share?

Referring to the emergent LOSC, Sohn had predicted that a large number of disputes would inevitably arise under it since many of its provisions were "very complicated, ... unclear, ... [and] contradictory...." 154 During the 1974 Caracas Session of UNCLOS III, Ambassador Galindo Pohl of El Salvador summarised four main goals of having dispute settlement mechanisms in the Convention. ${ }^{155}$ In the first place, it was believed that effective dispute settlement would preserve the equality of states and prevent the use of political, economic and military might in the dispute situations; secondly dispute settlement would ensure the greatest possible uniformity in the interpretation of the Convention; thirdly, exceptions to compulsory dispute settlement procedures would need to be determined carefully in view of the advantages of compulsory dispute settlement; and fourthly, the incorporation of dispute settlement provisions into the body of the Convention was desirable as against having it annexed as an optional protocol. $^{156}$

Sohn has pointed out that in dispute situations, deadlocks would result from states claiming that their interpretation of the law should prevail over that

\footnotetext{
${ }^{152}$ On the role of ITLOS in protecting the freedom of navigation, see Ivan A "The International Tribunal for the Law of the Sea and its Potential for Resolving Navigational Disputes" in Donald R Rothwell and Sam Bateman (eds) Navigational Rights and Freedoms and the New Law of the Sea (Kluwer Law International, The Hague, 2000) 263.

${ }^{153}$ John R Stevenson and Bernard H Oxman "The Third United Nations Conference on the Law of the Sea: The 1975 Geneva Session" (1975) 69 AJIL 763, 796.

${ }^{154}$ Louis B Sohn "UN Conference on the Law of the Sea" (1978) 12 (1) Intl Law 51, 52.

${ }^{155}$ A O Adede "Prolegomena to the Disputes Settlement Part of the Law of the Sea Convention" (1977) 10 (2) NYU J Intl L \& Pol 253, 255 - 256 ["Prolegomena to the Disputes Settlement Part"].

156 "Prolegomena to the Disputes Settlement Part", above n 155, 256.
} 
of the other - a tricky situation complicated by the principle of sovereign equality. ${ }^{157}$ This is in fact what was beginning to look like a global phenomenon with groups of states unilaterally claiming wider areas of the oceans under national jurisdiction, hence giving rise to global tensions from such "creeping jurisdiction." 158 It was felt that the key to break such deadlocks arguably lay in pursuing dispute settlement options before international tribunals for equitable solutions. ${ }^{159}$

Having discussed the basis for the incorporation of the dispute settlement provisions in the LOSC, the following paragraphs will seek the links between oceans governance, law and dispute settlement.

International law and legal arrangements such as dispute settlement mechanisms provide the formal base of international regimes such as global oceans governance. ${ }^{160}$ Lee Kimball has argued: ${ }^{161}$

\begin{abstract}
International ocean law establishes the basis for pursuing sustainable ocean development. A formal legal agreement sets down what each nation may expect of the other; it provides continuity and avoids ad hoc or arbitrary action...It may be more useful to consider them as management tools: they set out the "how-tos" when it comes to implementing international commitments.
\end{abstract}

A number of commentators have briefly alluded to the place that that law and dispute settlement have in oceans governance. ${ }^{162}$ The generally identified areas of contribution in this regard are: (i) enforcement and implementation of the LOSC, ${ }^{163}$ (ii) the logical pursuit of the notion of the common heritage of

\footnotetext{
157 "The Importance of the Peaceful Settlement of Disputes Provisions", above n 150, 266.

${ }^{158}$ Elliot L Richardson "Historical Evolution of the United Nations Convention on the Law of the Sea" (1995) 7 Geo Intl Envtl L Rev 639, 640. See generally M Dahmani The Fisheries Regime of the Exclusive Economic Zone (Martinus Nijhoff Publishers, Dordrecht, 1987) 14 - 29; Winston Conrad Extavour The Exclusive Economic Zone: A Study of the Evolution and Progressive Dvelopment of the International Law of the Sea (Sijthoff, Leiden, 1979); Robert W Smith Exclusive Economic Zone Claims: An Analysis and Primary Documents (Martinus Nijhhoff Publishers, Dordrecht, 1986) $3-17$.

159 "The Importance of the Peaceful Settlement of Disputes Provisions", above n 150, 266.

${ }^{160}$ See International Law and Ocean Use Management, above n 77, 3.

161 International Ocean Governance: Using International Law and Organizations to Manage Marine Resources Sustainably, above n 39, 45.

${ }^{162}$ For a visionary structure of oceans governance in the twenty first century, see Elisabeth Mann Borgese "Pacem in Maribus XIX - Background Paper" in Peter Bautista Payoyo (ed) Ocean Governance: Sustainable Development of the Seas (United Nations University Press, Tokyo, 1994) 350, 354.

${ }^{163}$ Pureza, above n 39, 75; Abdul G Koroma "Implementation of the Law of the Sea Convention Through Its Institutions: An Overview" in Davor Vidas and Willy Østreng (eds) Order for the Oceans at the Turn of the Century (Kluwer Law International, The Hague, 1999) 57; Herbert and Shaw, above n 1, 211; Thomas A Mensah "The International Tribunal for the Law of the Sea and
} 
mankind and the maintenance of its integrity, ${ }^{164}$ (iii) application and unification of substantive legal provisions, ${ }^{165}$ and (iv) providing protection from abuse. ${ }^{166}$

The actors who play a role in any area of governance are both diverse in number as well as kind. ${ }^{167}$ Arguably, the participatory gap in global governance is often bridged by involving actors from diverse sectors and levels in the policy making process. ${ }^{168}$ The case of oceans governance is no exception to this observed phenomenon. A wide range of actors and institutions could claim their contribution to oceans governance on national, regional, and global levels. Dispute settlement bodies as institutions in oceans governance, hold the potential to influence oceans governance across all levels - international, regional and national. Miles has asserted that at least at the global level, the dispute settlement procedures of the LOSC constitute one of the "crucial elements of ocean governance." 169

The contribution that dispute settlement mechanisms under the Convention could have on oceans governance could range from small to large, and could cut across various levels. For example, a dispute between two neighbouring coastal states regarding the sustainable harvest of straddling fish stocks ${ }^{170}$ in their EEZs could be settled by ITLOS. ${ }^{171}$ A clarification of the law by ITLOS as well as the emergence of equitable principles for the joint development and exploitation of straddling fish stocks may accompany such

the Protection and Preservation of the Marine Environment" (1999) 8 (1) RECIEL 1 ["ITLOS and the Protection and Preservation of the Marine Environment - 1999"].

${ }^{164}$ Jan van Ettinger, Alexander King and Peter Payoyo "Ocean Governance and the Global Picture" in Peter Bautista Payoyo (ed) Ocean Governance: Sustainable Development of the Seas (United Nations University Press, Tokyo, 1994) 247, 252; Louis B Sohn "Settlement of Law of the Sea Disputes" (1995) 10 (2) IJMCL 205, 205.

${ }^{165}$ Edward L Miles "The Concept of Ocean Governance: Evolution Toward the 21st Century and the Principle of Sustainable Ocean Use" (1999) 27 Coastal Management 1, 5 ["The Concept of Ocean Governance"].

${ }^{166}$ Zeller, above $\mathrm{n} 83,13$.

${ }^{167}$ Our Global Neighbourhood, above n 51, 3.

${ }^{168}$ Wolfgang H Reinicke and others Critical Choices: The United Nations, Networks, and the Future of Global Governance (International Development Research Centre, Ottawa, 2000) 114.

${ }^{169}$ “The Concept of Ocean Governance", above n 165, 2.

${ }^{170}$ For an explanatory diagrammatic representation of such sharing of straddling stocks between coastal states and accompanying discussion, see Serge M Garcia and Moritaka Hayashi "Division of the Oceans and Ecosystem Management: A Contrastive Spatial Evolution of Marine Fisheries Governance" (2000) 43 Ocean \& Coastal Management 445, 452.

${ }^{171}$ Fish stocks completely within a State's jurisdiction do not give rise to international disputes. However, since a substantial part of the world's fish stocks are shared among states either in the EEZs or high seas, the chances of interstate distributional disputes are quite high. Alf Hakon Hoel and Ingrid Kvalvik "The Allocation of Scarce Natural Resources: The Case of Fisheries" Marine Policy (Article in Press) 8. 
settlement. Therefore key elements of the judgment may help other groups of states in other parts of the world facing similar legal-management issues to settle their differences. This may also influence institutions such as Regional Fisheries Management Organisations (RFMO) to develop strategies for similar fisheries management on a regional scale. It merits mention in this context that some highly distinguished commentators on oceans governance issues have argued that provisions for the effective settlement of disputes are an integral part of the governance of coastal and marine spaces. ${ }^{172}$ They have argued that oceans governance has at least four functions: ${ }^{173}$

\begin{abstract}
[A]llocation within society and among government organizations of rights of use, ownership, and stewardship to marine resources; regulation of these rights of use, ownership, and stewardship; monitoring and enforcement of these regulations by the appropriate authorities; [and] provision of effective means to prevent and adjudicate disputes.
\end{abstract}

As is evident from the above lines, oceans governance involves the effective settlement of disputes, and by corollary the importance of the role of dispute settlement mechanisms in oceans governance becomes apparent. Nichols has also argued that good oceans governance is about having "the inclusive institutional structures needed to prevent and adjudicate disputes." ${ }^{174}$ Similarly, it has been asserted elsewhere that one of the basic principles of oceans governance is the maintenance of "substantive ocean governance laws as the foundation for enhanced policy coordination, and conflict resolution mechanism." ${ }^{175}$ Though the arguments were generally advanced in a national perspective, it is argued that they are also applicable in the international level.

\footnotetext{
${ }^{172}$ Sue Nichols, David Monahan and Michael D Sutherland "Good Governance of Canada's Offshore and Coastal Zone: Towards and understanding of the Maritime Boundary Issues" (2000) $54 \quad$ (4) Geomatica, 415. Also available at $<$ http://gge.unb.ca/Research/OceanGov/documents/geomatica.pdf $>$ (last accessed 14 November 2005) 4.

${ }^{173}$ Nichols, Monahan and Sutherland, above n 172, 4.

${ }^{174}$ Sue Nichols "It's Our Ocean: How Well Will We Govern it?" in Offshore Issues Consultation Workshop, Association of Canada Lands Surveyors (Halifax, 2001), available at $<$ http://gge.unb.ca/Research/OceanGov/documents/LUNCH.PPT> (last accessed 14 November 2005).

${ }^{175}$ General Public Comment from the National Ocean Industries Association and others to the United States Commission on Ocean Policy (2002), available at $<\mathrm{http}$ //www.oceancommission.gov/publicomment/novgencomment/fry_comment.pdf $>$ (last accessed 15 November 2005) 2.
} 
Thus it is argued that since the LOSC provides a set of robust dispute settlement mechanisms that could be effectively utilised to implement and enforce its provisions, it is argued that the dispute settlement mechanisms have an important part to play in oceans governance. This potential for contribution becomes more pronounced in the light of the fact that the dispute settlement provisions in the Convention may be invoked not only for tackling disputes arising out of the interpretation and application of the Convention itself but also related agreements. ${ }^{176}$ For example, Philippe Gautier has catalogued a nonexhaustive list of seven international agreements that contain provisions stipulating disputes arising out of the interpretation or application of these agreements would be referred to ITLOS. ${ }^{177}$

International oceans governance efforts are not merely confined at the international level, and go a long way in influencing oceans governance at national and local levels. Principles and strategies developed on international and regional planes could find expression in national laws and policies ${ }^{178}$ for oceans governance in several different ways. ${ }^{179}$ Depending upon the nature of a case that is settled under the dispute settlement provisions under Part XV of the

\footnotetext{
${ }^{176}$ LOSC, art 288(2). See Thomas A Mensah "The Place of the International Tribunal for the Law of the Sea in the International System for the Peaceful Settlement of Disputes" in P Chandrasekhara Rao and Rahmatullah Khan (eds) International Tribunal for the Law of the Sea: Law and Practice (Kluwer Law International, The Hague, 2001) 21, 29.

177 Philippe Gautier "The International Tribunal for the Law of the Sea: Activities in 2003" (2004) 3 Chinese J Intl L 241, 251 - 252. The agreements mentioned in footnote 27 of the article are: (i) 1996 Protocol to the Convention on the Prevention of Marine Pollution by Dumping of Wastes and Other Matter, 1972, (ii) Agreement for the Implementation of the Provisions of the United Nations Convention on the Law of the Sea of 10 December 1982 relating to the Conservation and Management of Straddling Fish Stocks and Highly Migratory Fish Stocks, (iii) Agreement to Promote Compliance with International Conservation and Management Measures by Fishing Vessels on the High Seas, (iv) Agreement for the Conservation of Fishery Resources in the High Seas of the South - East Pacific, (v) Convention on the Protection of the Underwater Cultural Heritage, (vi) Convention on the Conservation and Management of Highly Migratory Fish Stocks in the Western and Central Pacific Ocean, and (vii) Convention on the Conservation and Management of Fishery Resources in the South - East Atlantic Ocean.

${ }^{178}$ Edgar Gold "From Process to Reality: Adopting Domestic Legislation for the Implementation of the Law of the Sea Convention" in Davor Vidas and Willy Østreng (eds) Order for the Oceans at the Turn of the Century (Kluwer Law International, The Hague, 1999) 375.

${ }^{179}$ Robert W Knecht "A Perspective on Recent Developments That Could Affect the Nature of Ocean Governance Regimes" in Thomas A Mensah (ed) Ocean Governance: Strategies and Approaches for the 21st Century (The Law of the Sea Institute, University of Hawaii, Honolulu, 1994) 177, 188. See Oran R Young "Institutional Interplay: The Environmental Consequences of Cross-Scale Interactions" in Elinor Ostrom and others (eds) The Drama of the Commons (National Academy Press, Washington DC, 2002) 263. Young demonstrates the vertical and horizontal linkages between institutions across the national, regional and international levels in marine resource regimes. See generally Nicola Kieves "Crisis at Sea: Strengthening Government Regulation to Save Marine Fisheries” (2005) 89 Minn L Rev 1876.
} 
Convention, ${ }^{180}$ emergent decisions, advice, suggestions or findings could shape oceans governance on national, ${ }^{181}$ regional or international levels. Over a period of time, as the law of the sea continues to be in force and states parties abide by it, "the body of law developed through arbitration and adjudication in [various] matters may be very significant in filling in the details of how the oceans may be used." 182

It is argued that even the non-compulsory general provisions for dispute settlement under the Convention have a role to play in oceans governance. The popular belief is that the dispute settlement provisions under Part XV of the Convention have merely expanded the role for third-party dispute settlement in maritime disputes. ${ }^{183}$ It is to be remembered that the compulsory third-party dispute settlement procedures under Section 2 of Part XV can only be used after parties have been unable to settle their dispute under the provisions of Section 1. ${ }^{184}$ Article 280 of the Convention gives full freedom to the Parties to a dispute to settle it in any peaceful manner of their choosing. ${ }^{185}$ Not only this, Article 283 of the Convention also encourages disputant states to enter into negotiations under a general obligation to exchange views. ${ }^{186}$ It is true that the first and natural tendency of states is to settle their disputes through negotiated agreements. ${ }^{187}$ However, it is argued that having the duty to exchange views and to negotiate, codified under the dispute settlement provisions of the LOSC goes a long way in reinforcing the value of informal dispute settlement modes in ocean disputes. Encouraging disputant states to settle their disputes in any peaceful manner of their choice considerably rules out the potential for disputes to escalate into breaches of peace, and therefore leads to better oceans governance.

\footnotetext{
${ }^{180}$ See part I of chapter 3 of present thesis for a summary of the main dispute settlement provisions of the LOSC.

${ }^{181}$ See generally Anthony Mason "International Law as a Source of Domestic Law" in Brian R Opeskin and Donald R Rothwell (eds) International Law and Australian Federalism (Melbourne University Press, Carlton South, Victoria, 1997) 210 and Ivan A Shearer "The Relationship Between International Law and Domestic Law" in Brian R Opeskin and Donald R Rothwell (eds) International Law and Australian Federalism (Melbourne University Press, Carlton South, Victoria, 1997) 34.

${ }^{182}$ International Law and Ocean Use Management, above n 77, 238

${ }^{183}$ McDorman and Chircop, above n 146, 353.

${ }^{184}$ LOSC, art 286.

${ }^{185}$ LOSC, art 280.

${ }^{186}$ LOSC, art 283(1).

${ }^{187}$ McDorman and Chircop, above n 146, 352.
} 
The environmental focus in the governance of the oceans is a fairly new development in the international legal system. ${ }^{188}$ As was argued previously in part III, although the use of binding dispute settlement procedures in environmental disputes is limited, the very presence of dispute settlement mechanisms, binding or non-binding, plays an important part in environmental governance. Likewise, the importance of authoritative and binding dispute settlement, particularly within the environmental framework of oceans governance can be stressed. The dispute settlement mechanisms have the potential to produce substantive outcomes in oceans governance. Gwenaele Rashbrooke has argued that from the perspective of international environmental law, the dispute settlement mechanisms of the LOSC are of considerable merit. ${ }^{189}$ They provide an option to enforce the environmental obligations under the Convention through compulsory dispute settlement procedures as against the soft law obligations generally present in environmental agreements. ${ }^{190}$ Without a binding and authoritative dispute settlement system, irresponsible actions by one nation could undo the efforts of other nations towards good environmental oceans governance. ${ }^{191}$ Thomas Mensah has argued, that as an integral part of the dispute settlement system of the Convention, ITLOS can contribute to marine environmental protection and preservation by settling disputes centring on environmental protection between states. ${ }^{192}$ Mensah has also stressed that the Chamber for Marine Environment Disputes at the Tribunal can help states settle their disputes in a "user-friendly" manner. ${ }^{193}$

\footnotetext{
${ }^{188}$ Douglas M Johnston "The Environmental Law of the Sea: Historical Development" in Douglas M Johnston (ed) The Environmental Law of the Sea (IUCN Environmental Policy and Law Paper No 18, IUCN, Gland, Switzerland, 1981) 17, 20. See also A R Carnegie "The Challenge of Environmental Law to the Montego Bay Convention" (1995) 25/6 Envtl Poly \& L 302.

${ }^{189}$ Gwenaele Rashbrooke "The International Tribunal for the Law of the Sea: A Forum for the Development of Principles of International Environmental Law?" (2004) 19 (4) IJMCL 515, 516. See also Donald R Rothwell "Conflict Resolution and the Law of the Sea: Reconciling Interaction between the LOS Convention and Environmental Instruments" in Alexander Kiss, Dinah Shelton and Kanami Ishibashi (eds) Economic Globalization and Compliance with International Environmental Agreements (Kluwer Law International, The Hague, 2003) 255.

${ }^{190}$ Gwenaele Rashbrooke, above n 189, 516.

${ }^{191}$ See Palmer, above 132, 283.

192 Thomas A Mensah "The International Tribunal and the Protection and Preservation of the Marine Environment" (1998) 28/5 Environmental Policy \& Law 216.

193 "ITLOS and the Protection and Preservation of the Marine Environment - 1999", above n $163,4-5$.
} 
It has been convincingly asserted elsewhere ${ }^{194}$ that the foundation for effective oceans governance lies in the provisions of the LOSC and its implementing agreements - the Agreement Relating to the Implementation of Part XI of the United Nations Convention on the Law of the Sea of 10 December 1982, ${ }^{195}$ and the Agreement for the Implementation of the Provisions of the United Nations Convention on the Law of the Sea of 10 December 1982 Relating to the Conservation and Management of Straddling Fish Stocks and Highly Migratory Fish Stocks (Fish Stocks Agreement). ${ }^{196}$ IWCO also gave credit to other legal arrangements and mechanisms that have been contributing to effective oceans governance - such as the Agenda 21, and efforts on climate change, biodiversity and land-based sources of marine pollution on a global scale along with other agreements concluded on regional and sub-regional levels. ${ }^{197}$ It is not surprising, therefore, that experts have argued that efforts to build a more effective system of oceans governance must begin with the implementation of the LOSC and many other legal instruments concerning ocean issues. ${ }^{198}$ Indeed, the view that the major problem with oceans governance today is not so much with respect to the legal framework at the international level, but more with regard to the implementation of the provisions of the Convention in national laws has merit. ${ }^{199}$

\footnotetext{
${ }^{194}$ Independent World Commission on the Oceans The Ocean Our Future: The Report of the Independent World Commission on the Oceans (Cambridge University Press, Cambridge, 1998) 21 [The Ocean Our Future].

${ }_{195}$ Agreement Relating to the Implementation of Part XI of the United Nations Convention on the Law of the Sea of 10 December 1982 (28 July 1994) 1836 UNTS 3.

${ }^{196}$ Agreement for the Implementation of the Provisions of the United Nations Convention on the Law of the Sea of 10 December 1982 Relating to the Conservation and Management of Straddling Fish Stocks and Highly Migratory Fish Stocks (4 August 1995) 2167 UNTS 3 [Fish Stocks Agreement]. For a review of this Agreement, see Moritaka Hayashi "The 1995 UN Fish Stocks Agreement and the Law of the Sea" in Davor Vidas and Willy Østreng (eds) Order for the Oceans at the Turn of the Century (Kluwer Law International, The Hague, 1999) 37.

${ }^{197}$ The Ocean Our Future, above n 194, 21.

${ }^{198}$ The Ocean Our Future, above n 194, 22. See also See Greenpeace Freedom for the Seas, for Now \& for the Future: Greenpeace Proposals to Revolutionise High Seas Oceans Governance (Greenpeace International, Amsterdam, 2005), available at $<\mathrm{http}: / /$ www.greenpeace.org/raw/content/international/press/reports/freedom-for-seas.pdf $>$ (last accessed 15 November 2005).

${ }^{199}$ Satya N Nandan "Multilateral Oceans Governance and the International Seabed Authority" in International Governance And Institutions: What Significance For International Law? Proceedings of the Eleventh Annual Conference of the Australian and New Zealand Society of International Law (Wellington, 2003) 300, 305 ["Multilateral Oceans Governance and the International Seabed Authority"]. On the various levels of implementation of international regimes, see Edward L Miles "Implementation of International Regimes: A Typology" in Davor Vidas and Willy Østreng (eds) Order for the Oceans at the Turn of the Century (Kluwer Law International, The Hague, 1999) 327.
} 
There is no denying the fact that law and dispute settlement plays a vital role in maintaining peace and order in society. Similarly, it can be asserted that international law plays a comparable role in global governance. ${ }^{200}$ The fact that states have been creating standing international courts and tribunals since the $20^{\text {th }}$ century and their number has dramatically increased of late, ${ }^{201}$ demonstrates relevance for international dispute settlement in today's world. ${ }^{202}$

Dispute settlement can also have a positive impact in specific sectors within a wider plane of oceans governance. For instance, Howard Schiffman argues that unilateral actions to enforce compliance ${ }^{203}$ with International Whaling Commission's (IWC) regulations had, in the past, proved to be unworkable. $^{204}$ Overall, he concludes that the best available opportunity to address problems in this regard is through the dispute settlement procedures under the LOSC. ${ }^{205}$ This is because, he argues, the comprehensive nature of the LOSC nearly guarantees that actions on the part of states that undermine IWC regulations would come under its purview. ${ }^{206}$ Schiffman submits that it would be easy for an adjudicative body under the LOSC dispute settlement arrangement to interpret the LOSC and give substantive effect to policies designed to protect whales. $^{207}$

In the following paragraphs, some of the ways in which dispute settlement could positively influence oceans governance under its "public

\footnotetext{
200 Rahmatullah Khan "The Thickening Web of International Law" in Issues in Global Governance: Papers Written for the Commission on Global Governance (Kluwer Law International, London, 1995) 249, 255. Contrast Galina Shinkaretskaya "The Present and Future Role of International Adjudication as a Means for Peacefully Settling Disputes” (1989) 29 (1\&2) Indian J Intl L 87, 88.

201 Jonathan I Charney "The Impact on the International Legal System of the Growth of International Courts and Tribunals" (1999) 31 NYUJ Intl L \& Pol 697, 697 - 698.

${ }^{202}$ See Louis B Sohn “The Future of Dispute Resolution” in Douglas M Johnston and Ronald St J Macdonald (eds) The Structure and Process of International Law: Essays in Legal Philosophy, Doctrine and Theory (Martinus Nijhoff Publishers, Boston, 1983) 1121, 1121 ["Future of Dispute Settlement"].

${ }^{203}$ For a good account of some recent developments towards ensuring compliance within the IWC, see Alexander Gillespie "The Search for a New Compliance Mechanism Within the International Whaling Commission" (2003) 34 ODIL 349.

${ }^{204}$ Howard Scott Schiffman "The Protection of Whales in International Law: A Perspective for the Next Century" (1996) 22 Brook J Intl L 303, 359 ["The Protection of Whales in International Law"]. One of the structural weaknesses of the IWC in not having dispute settlement mechanisms has been pointed out in more recent work. See Cinnamon Pinon Carlarne "Saving The Whales In The New Millennium: International Institutions, Recent Developments And The Future Of International Whaling Policies" (2005) 24 Va Envtl LJ 1, 46.

205 "The Protection of Whales in International Law", above n 204, 359.

206 "The Protection of Whales in International Law", above n 204, 344.

207 "The Protection of Whales in International Law", above n 204, 348.
} 
functions" are discussed individually under eight sub-divisions. However, such categorisation and discussion of the functions of dispute settlement mechanisms of the LOSC is not claimed to be an exhaustive one.

\section{A Regulate and Allocate Resources}

The enforcement of regimes, environmental or otherwise, such as those established by the LOSC, often gives rise to disputes of many types; be it on grounds of non-compliance on the part of a state party with established norms or of unilateral action by a country based upon its independent view of the law. ${ }^{208}$

The fundamental nature of the oceans in their vastness and diversity, accompanied by the many benefits that humans derive from them, signify the potential for many disputes, and hence a role for dispute settlement. The oceans represent an arena of conflicting uses ${ }^{209}$ and interests that will only increase in magnitude and extent with the passage of time. ${ }^{210}$ Since a significant portion of ocean uses are extractive in nature, the regulatory task in oceans governance must concentrate on sustainability as well as the allocation of available resources in an agreed-upon manner. Under such circumstances, utilising the compulsory dispute settlement mechanisms under the LOSC could perhaps lead to answers that are not available otherwise. At a time when the negotiations for the LOSC were underway, Arvid Pardo had stressed that dispute settlement systems were essential in the new ocean regime along with other international institutions, to play an essential regulatory and protective role. ${ }^{211}$

It is argued here that international litigation through adjudication or arbitration under Part XV could generally influence regulation and allocation under the law of the sea. There has been a considerable volume of literature that

\footnotetext{
208 M J Peterson "International Organizations and the Implementation of Environmental Regimes" in Oran R Young (ed) Global Governance: Drawing Insights from the Environmental Experience (The MIT Press, Cambridge (Mass), 2000) 115, 124.

${ }^{209}$ See Olav Schram Stokke "Governance of High Seas Fisheries: The Role of Regime Linkages" in Davor Vidas and Willy Østreng (eds) Order for the Oceans at the Turn of the Century (Kluwer Law International, The Hague, 1999) 157, 162.

${ }^{210}$ See The Ocean Our Future, above n 194, 140.

211 Arvid Pardo "New Institutions for Ocean Space" in Elisabeth Mann Borgese and David Krieger (eds) The Tides of Change: Peace, Pollution, and Potential of the Oceans (Mason/ Charter, New York, 1975) 324, 326.
} 
has discussed the phenomenon of "regulation through litigation" 212 in a variety of fields, and their merits and demerits. ${ }^{213}$ With no intention to reopen the debate $^{214}$ on "regulation through litigation," in perspective of the law of the sea, the author envisions a similar role that dispute settlement under the LOSC could have on regulation. This could be particularly possible when deep seabed mining turns commercial, and private entities engaged in seabed mining, being more open to the prospect of adjudication than states, ${ }^{215}$ bring lawsuits. The motives behind such lawsuits could be diverse and directed, for example to change the defendant's behaviour, ${ }^{216}$ or to plug regulatory loopholes. Dispute settlement procedures could aid in regulation by providing interpretation of existing norms, and in development of new norms that reinforce regulation and the rule of law.

It is also submitted that a shift in the basic conditions of the oceans, characterised by a growing scarcity of resources and increasing conflicts, ${ }^{217}$ has led to an increasing potential for dispute settlement mechanisms to find a greater role in oceans governance. The oceans have been aptly described as one of our last resources ${ }^{218}$ and the last frontier. ${ }^{219}$ The level of available resources, living and non-living, that are exploited from the sea are gradually dwindling. The oceans have witnessed people fight over its fish resources time and again in various parts of the world. ${ }^{220}$ Non-living resources have not been spared from

212 The coinage of this expression, first used with respect to tort law has been credited to Robert B Reich. He says, "[th] e era of big government may be over, but the era of regulation through litigation has just begun." Robert B Reich "Regulation is Out, Litigation is In" (February 1999) The American Prospect Online, available at $<$ http://www.prospect.org/webfeatures/1999/02/reich-r-02-11.html > (last accessed 11 November 2005).

${ }^{213}$ See generally W Kip Viscusi (ed) Regulation Through Litigation (AEI-Brookings Joint Center for Regulatory Studies, Washington DC, 2002). This volume contains articles discussing the regulatory nature of litigation in diverse areas and industries such as tobacco, guns, breast implants, lead-based paint, and medical malpractice.

${ }^{214}$ See generally Linda A Willett "Litigation as an Alternative to Regulation: Problems Created by Follow-on Lawsuits with Multiple Outcomes" (2005) 18 Geo J Legal Ethics 1477; Edward T Schroeder "A Tort by Any Other Name? In Search of the Distinction Between Regulation Through Litigation and Conventional Tort Law" (2005) 83 Tex L Rev 897.

${ }^{215}$ Andrew Serdy "The Paradoxical Success of UNCLOS Part XV: A Half-Hearted Reply to Rosemary Rayfuse" (2005) 36 VUWLR 713, 714.

216 See Kenneth A Abraham "The Insurance Effects of regulation by Litigation" in W Kip Viscusi (ed) Regulation Through Litigation (AEI-Brookings Joint Center for Regulatory Studies, Washington DC, 2002) 212, 232.

217 The Ocean Our Future, above n 194, 26.

${ }^{218}$ Wesley Marx The Oceans, Our Last Resource (Sierra Club Books, San Francisco, 1981).

${ }^{219}$ Lord Ritchie-Calder "In Quiet Enjoyment" in Elisabeth Mann Borgese (ed) Pacem in Maribus (Dodd, Mead \& Company, New York, 1972) 260, 264.

${ }^{220}$ Fisheries Jurisdiction (United Kingdom v Iceland) [1974] ICJ Rep 3; Fisheries Jurisdiction (Spain v Canada) [1995] ICJ Rep 87, Southern Bluefin Tuna Cases (New Zealand v Japan; 
disputes either, and nations have clashed with each other in the past over increasing their control over mineral resources found on their continental shelves. ${ }^{221}$ As resource levels hit all time lows in some areas and disappear altogether in others, ${ }^{222}$ the chances of countries entering into deeper conflicts and 'resource wars' increase further.

Under such dire circumstances, the dispute settlement system of the LOSC has the potential to save the order of the day, and help states to find ways to share and jointly develop resources - allocating resources, in a manner of speaking. This is entirely possible given the fact that most of the provisions of the LOSC are rules concerned with the fair allocation of ocean resources. ${ }^{223}$ As one commentator has written, Part XV could be well utilised to settle disputes about allocation - be it about "... fish stocks or rights to or over land or sea...."224 Since the dispute settlement mechanisms are designed to help in the application and interpretation of the LOSC, in the event of a dispute about ocean resources, they may aid in their just allocation.

Commentators have observed that the law of the sea has generated many disputes, ${ }^{225}$ a significant number of which revolved around resources. Boyle points out to 23 ocean related disputes that have been subjected to various dispute settlement processes since $1945 .{ }^{226}$ He further notes that: ${ }^{227}$

\footnotetext{
Australia $v$ Japan) (Provisional Measures) [1999] <http://www.itlos.org/> (last accessed 1 December 2005).

${ }^{221}$ North Sea Continental Shelf (Federal Republic of Germany/Denmark) [1967] ICJ Rep 3; North Sea Continental Shelf (Federal Republic of Germany/Netherlands) [1967] ICJ Rep 6.

${ }^{222}$ For example the state of marine fisheries in many parts of the world has been said to be in a state of crisis, see Harry N Scheiber "Ocean Governance and the Marine Fisheries Crisis: Two Decades of Innovation - and Frustration" (2001) 20 Va Envtl L J 119.

${ }^{223}$ Steve Rayner "Mapping Institutional Diversity for Implementing the Lisbon Principles" (1999) 31 Ecological Economics 259, 266.

${ }^{224}$ Serdy, above $\mathrm{n} 215,720$.

${ }^{225}$ Alan Boyle "Problems of Compulsory Jurisdiction and the Settlement of Disputes Relating to Straddling Fish Stocks" in Olav Schram Stokke (ed) Governing High Seas Fisheries: The Interplay of Regional Regimes (Oxford University Press, Oxford, 2001) 91, 91 ["Problems of Compulsory Jurisdiction and the Settlement of Disputes Relating to Straddling Fish Stocks"]; Alexander Yankov "Current Fisheries Disputes and the International Tribunal for the Law of the Sea" in M H Nordquist and J N Moore (eds) Current Marine Environmental Issues and the International Tribunal for the Law of the Sea (Kluwer Law International, The Hague, 2001) 223, 223.

226 "Problems of Compulsory Jurisdiction and the Settlement of Disputes Relating to Straddling Fish Stocks", above n 225, 91.

227 "Problems of Compulsory Jurisdiction and the Settlement of Disputes Relating to Straddling Fish Stocks", above n 225, 91.
} 
Nine of these twenty-three disputes were principally about fish stocks; four were disputes over fishing rights between coastal and distant water fishing states; and a further four dealt with maritime boundaries where fisheries were the principal economic interest at stake.

As is evident, fisheries and fishery related issues have been the subjects of many disputes over the years. ${ }^{228}$ In fact, on the linkages between oceans governance and dispute settlement, Richard Silk has argued that as the demand for fish increases in the face of ever-decreasing supply, the number and frequency of disputes are bound to increase. ${ }^{229}$ He further makes a strong point for the role of dispute settlement in fisheries governance, especially those that are binding and compulsory in nature. ${ }^{230}$ He argues: $:^{231}$

\begin{abstract}
[B]ecause history has demonstrated that most contemporary fisheries disputes are the result of stressed or collapsed fisheries, and because fisheries continue to decline, nonbinding dispute resolution methods are necessarily bound for failure because the result is a zero-sum gain. [...] Nearly all dispute resolution techniques generally are used as tools in the context of voluntary settlements. Thus, they oftentimes serve as the foundation from which subsequent decisions are made. Clearly, then, the binding nature and enforcement of a resolved dispute will have a significant effect on subsequent disputes over similar or related issues.
\end{abstract}

Silk however concedes that no amount of dispute settlement procedures would be able to settle fisheries disputes if the world were to face a situation where there are hardly any fish left to fight over. ${ }^{232}$ Further, the curious result of a zero-sum gain makes losers out of winners in dispute resolution procedures concentrating solely on resource allocation, as by "winning" disputants often hasten the collapse of the fishery. ${ }^{233}$ Though Silk's contention is not completely without merit, hinting at a potential for dispute settlement to undermine good oceans governance, it is argued that dispute settlement procedures would only fail to settle fisheries disputes if the underlying rules applied by the adjudicative body are ineffective. Besides, the world is much more conscious of the oceans'

\footnotetext{
${ }^{228}$ Alexander Yankov "Irregularities in Fishing Activities and the Role of the International Tribunal for the Law of the Sea" in Nisuke Endo and others (eds) Liber Amicorum Judge Shigeru Oda (vol 1, Kluwer Law International, The Hague, 2002) 773, 773.

${ }^{229}$ Richard J Silk Jr "Nonbinding Dispute Resolution Processes in Fisheries Conflicts: Fish Out of Water?" (2001) Ohio St J on Disp Resol 791, 792. See also Christopher C Joyner "Compliance and Enforcement in New International Fisheries Law" (1998) 12 Temp Intl \& Comp L J 271, 299.

${ }^{230}$ Silk, above n 229, 795 .

${ }^{231}$ Silk, above n 229,795 .

${ }^{232}$ Silk, above n $229,816$.

${ }^{233}$ Silk, above n 229, 795 and 817.
} 
state and needs than it was a century ago. Going by present marine conservation and protection efforts, it does not seem likely that the oceans will be emptied of its fishes in the foreseeable future. It has also been hoped that "[v]iable dispute settlement may reduce the likelihood of future clashes over fisheries" 234 and improve the prospects of good oceans governance.

Likewise, others have argued that one of the governance challenges faced in fisheries management happens to be in the "capability to resolve conflicts amongst competing users." ${ }^{235}$ Similarly, Stokke and Coffey have asserted that compulsory dispute settlement mechanisms are important drivers of institutional interaction and linkages between different regimes of fisheries governance. ${ }^{236}$ Here again the potential for dispute settlement in oceans governance is apparent.

As an 'implementing agreement' of the LOSC, the Fish Stocks Agreement seeks to govern straddling and highly migratory fish stocks in the high seas, beyond the areas of national jurisdiction. ${ }^{237}$ The value of dispute settlement in the Fish Stocks Agreement can be gauged from Satya Nandan's description of the Fish Stocks Agreement as being built on three essential pillars, one of which is its provisions for the peaceful settlement of disputes. ${ }^{238}$ Article 30 of the Fish Stocks Agreement provides that Part XV of the LOSC applies mutatis mutandis to any dispute concerning its interpretation or application, irrespective of whether the parties to such disputes are parties to the LOSC. ${ }^{239}$ Therefore, a state that is not a party to the LOSC but is a party to the Fish Stocks Agreement can avail of the dispute settlement mechanisms of the LOSC if

\footnotetext{
${ }^{234}$ Alan Bracegirdle "New Zealand v Japan, Australia v Japan (Southern Bluefin Tuna Cases) International Tribunal for the Law of the Sea, 27 August 1999) [1995] NZLJ 375, 375.

${ }^{235}$ Henrik Gislason and others "Symposium Overview: Incorporating Ecosystem Objectives Within Fisheries Management" (2000) 57 ICES Journal of Marine Science 468, 474.

${ }^{236}$ Olav Schram Stokke and Clare Coffey "Institutional Interaction in the High Seas Fisheries Management: An Inventory" in Sebastian Oberthür (co-ordinator) Institutional Interaction: How to Prevent Conflicts and Enhance Synergies Between International and EU Environmental Institutions (Project Deliverable No D8, Ecologic - Institute for International and European Environmental Policy Berlin, 2001) 21, available at $<$ http://www.ecologic.de/ $>$ (last accessed 20 November 2005).

${ }^{237}$ Fish Stocks Agreement, above n 196, art 3.

${ }^{238}$ Satya N Nandan "Current Fisheries Governance" in Conference on the Governance of High Seas Fisheries and the UN Fish Agreement - Moving From Words to Action (St. John's, Newfoundland and Labrador, 2005) 1 available at <http://www.dfo-mpo.gc.ca/fgccgp/documents/presentations/nandan_e.pdf $>$ (last accessed 20 November 2005). See also Michale W Lodge and Satya N Nandan "Some Suggestions Towards Better Implementation of the United Nations Agreement on Straddling Fish Stocks and Highly Migratory Fish Stocks of 1995” (2005) 20 (2-3) IJMCL 345, 351 - 352.

239 "Problems of Compulsory Jurisdiction and the Settlement of Disputes Relating to Straddling Fish Stocks", above n 225, 109.
} 
required. It is submitted that in so expanding the accessibility of the dispute settlement machinery of the LOSC, the Fish Stocks Agreement has increased its potential to contribute to oceans governance.

Therefore, the LOSC dispute settlement mechanisms have plenty of potential to contribute to oceans governance through regulation and resource allocation. This is mainly because of the very nature of the oceans and the many extractive activities that humans carry out in them. Such activities can often lead to disputes where the dispute settlement mechanisms could be invoked, and they in turn could by their findings and decisions play a role in oceans governance.

\section{B Maritime Boundary Delimitation}

The role played by maritime boundary delimitation in the oceans governance process has been emphasised as well as questioned. One school of thought holds that delimiting maritime boundaries actually improves oceans governance since just as in the terrestrial sense, "good fences make good neighbours," 240 in the marine world "good boundaries make good neighbours." 241 Some others opine that delimitation of maritime boundaries is unnecessary where co-management of resources is a better option. ${ }^{242}$ Giving credence to both views, it is submitted that in the event of a dispute, dispute settlement mechanisms can be effective in maritime boundary delimitation, ${ }^{243}$ and therefore contribute to oceans governance. ICJ has a hallowed history in international maritime boundary delimitation, ${ }^{244}$ and has effectively settled

\footnotetext{
${ }^{240}$ Robert Frost "Mending Wall" in Edward Connery Lathem (ed) The Poetry of Robert Frost: The Collected Poems, Complete and Unabridged (Henry Holt \& Company, New York, 1969) 33.

${ }^{241}$ Sam Ng'ang'a and others "Toward a Multidimensional Marine Cadastre in Support of Good Ocean Governance" in International Conference on Spatial Information for Sustainable Development (Nairobi, 2001), available at $<$ http://www.fig.net/pub/proceedings/nairobi/nganganichols-sutherland-cockburn-TS12-3.pdf $>$ (last accessed 26 October 2005) 7.

${ }^{242} \mathrm{Ng}$ 'ang'a and others, above n 241, 7.

${ }^{243}$ See Francisco Orrego Vicuña "The Role of the International Court of Justice and Other Tribunals in the Development of the Law of Maritime Delimitation" in Alfred H A Soons (ed) Implementation of the Law of the Sea Convention through International Institutions (Law of the Sea Institute, University of Hawaii, Honolulu, 1990) 601.

${ }^{244}$ See Robin R Churchill "The Role of the International Court of Justice in Maritime Boundary Delimitation" in Alex G Oude Elferink and Donald R Rothwell Oceans Management in the 21st Century: Institutional Frameworks and Responses (Martinus Nijhoff Publishers, Leiden, 2004) 125 .
} 
maritime boundary disputes faced with key issues ranging from territorial sovereignty $^{245}$ to co-management of fishery resources. ${ }^{246}$

Sutherland and Nichols have briefly explored the connections between maritime boundary delimitation and oceans governance. ${ }^{247}$ Sutherland and Nichols have stressed the importance of the availability of accurate information in the maritime boundary delimitation process, which in turn is an important element of oceans governance. ${ }^{248}$ It is argued that maritime boundary delimitation is integral to oceans governance as "uncertain jurisdiction, undefined and ambiguous boundaries, as well as the possibility of increasing conflicts between customary, public and private interests," 249 are impediments in the path of good oceans governance. Having internationally recognised maritime boundaries in place are an important step to ensuring that many challenges of oceans governance are capable of better management. ${ }^{250}$ Churchill and Ulfstein have noted that the potential for conflict and friction among riparian states is always high, and without agreed maritime boundaries, oceans governance, particularly with regard to resource management becomes more difficult. ${ }^{251}$

The connection between maritime boundary delimitation and dispute settlement has become profoundly clear in the large number of maritime boundary disputes that the world has seen in the last century. ${ }^{252}$ The uncertainties in the maritime boundaries between countries have often been the cause of

\footnotetext{
245 Case Concerning Maritime Delimitation and Territorial Questions between Qatar and Bahrain (Qatar v Bahrain) (Merits) [2001] ICJ Rep 40.

${ }^{246}$ Case Concerning Delimitation of the Maritime Boundary in the Gulf of Maine Area (Canada $v$ United States of America) (Merits) [1984] ICJ Rep 246. For more references to ICJ's maritime boundary delimitation cases, see Barbara Kwaitkowska Decisions of the World Court Relevant to the UN Convention on the Law of the Sea - A Reference Guide (Kluwer Law International, The Hague, 2002) 193.

247 Michael Sutherland and Susan Nichols "Maritime Boundary Delimitation for Ocean Governance" in FIG Technical Program Proceedings, XXII FIG International Congress (Washington DC, 2002) ["Maritime Boundary Delimitation for Ocean Governance"].

248 "Maritime Boundary Delimitation for Ocean Governance", above n 247, 9.

249 "Maritime Boundary Delimitation for Ocean Governance", above n 247, 7.

${ }^{250}$ See Sue Nichols and David Monahan "Fuzzy Boundaries in a Sea of Uncertainty" in The Coastal Cadastre - Onland, Offshore, Proceedings of the New Zealand Institute of Surveyors Annual Meeting (Bay of Islands, New Zealand, 1999) 33.

${ }^{251}$ Robin Churchill and Geir Ulfstein Marine Management in Disputed Areas: The Case of the Barents Sea (Routledge, London, 1992) 1.

${ }^{252}$ For a bibliography on maritime boundary delimitation along with annotations, see Ted L McDorman, Kenneth P Beauchamp, Douglas M Johnston Maritime Boundary Delimitation: An Annotated Bibliography (LexingtonBooks, Lexington (Mass), 1983).
} 
disputes. ${ }^{253}$ Maritime boundary disputes have become a common feature in international relations with rapid strides in science and technology, which have increased accessibility to oceanic resources. ${ }^{254}$ As science ${ }^{255}$ and technology opens up more areas of ocean space previously undiscovered by humans, the potential for disputes increases in the absence of clearly delimited maritime boundaries. Clive Schofield argues that maritime boundaries provide clarity and certainty and enhance maritime security besides facilitating sustainable management and ocean resource preservation. ${ }^{256}$ Schofield also estimates that out of a total of 427 potential maritime boundaries, only 168, or 39 per cent, have been formally agreed. ${ }^{257}$

However, the role of third-party dispute settlement mechanisms in maritime boundary delimitation has been quite limited in the history of maritime boundary settlement. An excellent work of authority and repute in the area of maritime boundaries, published in the last decade recorded up to 135 maritime boundary settlements out of which only nine resulted from the use of formal dispute settlement procedures. ${ }^{258}$ However, a recent publication dedicated to maritime boundary disputes settled by third-party dispute settlement lists 13

\footnotetext{
${ }^{253}$ Alexander Yankov "The International Tribunal for the Law of the Sea and the Comprehensive Dispute Settlement System of the Law of the Sea" in P Chandrasekhara Rao and Rahmatullah Khan (eds) International Tribunal for the Law of the Sea: Law and Practice (Kluwer Law International, The Hague, 2001) 33, 40 ["The International Tribunal for the Law of the Sea and the Comprehensive Dispute Settlement System of the Law of the Sea"].

254 "The International Tribunal for the Law of the Sea and the Comprehensive Dispute Settlement System of the Law of the Sea", above $n$ 253, 40.

${ }^{255}$ For a perspective on how science shapes the path of oceans governance, see Donald F Boesch "The Role of Science in Ocean Governance" (1999) 31 Ecological Economics 189.

${ }^{256}$ Clive Schofield "Cooperative Mechanisms and Maritime Security in Areas of Overlapping Claims to Maritime Jurisdiction" in Peter Cozens and Joanna Mossop (eds) Capacity Building for Maritime Security Cooperation in the Asia-Pacific (Centre for Strategic Studies, Wellington, 2005) 99, $101-102$.

${ }^{257}$ Schofield, above n 256, 100.

${ }^{258}$ See Jonathan I Charney and Lewis M Alexander (eds) International Maritime Boundaries (vol 1, Martinus Nijhoff Publishers, Dordrecht, 1993); Jonathan I Charney and Lewis M Alexander (eds) International Maritime Boundaries (vol 2, Martinus Nijhoff Publishers, Dordrecht, 1993). For more recent volumes, see Jonathan I Charney and Lewis M Alexander (eds) International Maritime Boundaries (vol 3, Martinus Nijhoff Publishers, Dordrecht, 1998); Jonathan I Charney and Robert W Smith (eds) International Maritime Boundaries (vol 4, Martinus Nijhoff Publishers, Dordrecht, 2002); David A Colson and Robert W Smith (eds) International Maritime Boundaries (vol 5, Martinus Nijhoff Publishers, Leiden, 2005); John Robert Victor and Clive Schofield The Maritime Political Boundaries of the World (Martinus Nijhoff Publishers, Leiden, 2005). For a detailed study in maritime boundaries and the debates and negotiations in UNCLOS III on maritime boundary issues, see S P Jagota Maritime Boundary (Martinus Nijhoff Publishers, Dordrecht, 1985).
} 
cases. $^{259}$ The recent Case Concerning the Maritime Delimitation and Territorial Questions Between Qatar and Bahrain ${ }^{260}$ deserves mention in this regard. Here, ICJ played a very important role not merely indicating the applicable principles and rules for delimitation, but drawing a single and concrete line of delimitation in the waters between the two countries. ${ }^{261}$

Notwithstanding the disproportionate number of maritime boundary settlements achieved by litigation and negotiation, ${ }^{262}$ Keith Highet gives international courts and tribunals credit by arguing: ${ }^{263}$

...that the very existence of judicial or arbitral decisions will assist States in arriving at settlements, by disenchanting them of excessive claims positions dearly held and persuading them that they can do probably no better by going outside their own will to a third-part decision-maker such as the Court or another tribunal.

Highet anticipates that the overall effect of Part XV of the Convention would lead to states settling their maritime boundary disputes without recourse to either the ICJ or ITLOS. ${ }^{264}$ Nevertheless, he believes that the Annex VIII

\footnotetext{
${ }^{259}$ Robert Kolb Case Law on Equitable Maritime Delimitation (Martinus Nijhoff Publishers, The Hague, 2003). The 13 cases are the: Grisbadarna Case (Norway v Sweden); North Sea Continental Shelf Cases (Federal Republic of Germany v Denmark, and Federal Republic of Germany v Netherlands); Case Concerning the Delimitation of the Continental Shelf between the United Kingdom and France (United Kingdom of Great Britain and Northern Ireland $v$ French Republic); Boundary Dispute between Dubai and Sharjah (Emirate of Dubai v Emirate of Sharjah); Continental Shelf Case (Tunisia/ Libya); Case Concerning the Delimitation of the Maritime Boundary in the Area of the Gulf of Maine (Canada/ United States of America); Case of the Delimitation of the Maritime Boundary between Guinea and Guinea-Bissau (Republic of Guinea v Republic of Guinea-Bissau); Case Concerning the Continental Shelf (Libya/ Malta); Case of the Maritime Boundary Delimitation between Guinea-Bissau and Senegal (Republic of Guinea-Bissau v Republic of Senegal); Case Concerning the Delimitation of Maritime Spaces between Canada and France (St. Pierre and Miquelon) (Canada v France); Case Concerning the Maritime Delimitation in the Area between Greenland and Jan Mayen (Denmark v Norway); Case of the Maritime Boundary Delimitation between Eritrea and Yemen (Eritrea v Republic of Yemen); Case Concerning the Maritime Delimitation and Territorial Questions between Qatar and Bahrain (Qatar v Bahrain).

${ }^{260}$ Case Concerning the Maritime Delimitation and Territorial Questions between Qatar and Bahrain (Qatar v Bahrain) [2001] ICJ Rep 40.

${ }^{261}$ Kolb, above n 259, 534

${ }^{262}$ For a good case study on the success of bilateral negotiations in maritime boundary delimitation, see Stuart Kaye "Negotiation and Dispute Resolution: A Case Study in International Boundary Making - The Australia-Indonesia Boundary" in Alex G Oude Elferink and Donald R Rothwell (eds) Ocean Management in the $21^{\text {st }}$ Century: Institutional Frameworks and Responses (Martinus Nijhoff Publishers, Leiden, 2004) 143.

${ }^{263}$ Keith Highet "Maritime Boundary Disputes and Settlement" in Mochtar Kusuma Atmadja, Thomas A Mensah and Bernard H Oxman (eds) Sustainable Development and Preservation of the Oceans: The Challenges of UNCLOS and Agenda 21 (The Law of the Sea Institute, University of Hawaii, Honolulu, 1997) 745, 746. See also Jonathan I Charney "Progress in International Maritime Boundary Delimitation Law" (1994) 88 AJIL 227, 227.

${ }^{264}$ Highet, above n 263, 765 .
} 
tribunals under the Convention with their panels of maritime experts would serve as the technical equivalent of the Permanent Court of Arbitration (PCA) and help in the settlement of future maritime boundary disputes. The author finds much merit in Highet's prediction and hopes that states would find the arrangements under Part XV attractive in settling their maritime boundary disputes when negotiations fail. This would afford the dispute settlement mechanisms opportunities to contribute to oceans governance. It needs to be pointed out here, that under Article 298(1)(a) of the Convention, states parties have the option to exclude certain maritime boundary disputes from the operation of compulsory dispute settlement procedures. ${ }^{265}$ However, sea boundary delimitation disputes are subject to compulsory conciliation under the Convention, and this reflects the importance of the need to finally settle maritime disputes. ${ }^{266}$ It needs to be noted that voluntary conciliation has not been in popular usage between disputing states. $^{267}$

Johnston argues that there are three main actors in ocean boundary making - bureaucracy, diplomacy and adjudication. ${ }^{268}$ He perceives a quasidiplomatic role for adjudicatory processes in ocean boundary making, least dominated by government officials. ${ }^{269}$ The importance of other forms of intermediation such as mediation and conciliation is also pointed out. ${ }^{270}$ The LOSC dispute settlement provisions make it possible for states to utilise any of the tools for maritime boundary delimitation as identified above. The potential role of dispute settlement provisions in oceans governance, particularly in

\footnotetext{
${ }^{265}$ For a detailed discussion, see Natalie Klein Dispute Settlement in the UN Convention on the Law of the Sea (Cambridge University Press, Cambridge, 2005), 227 - 279.

${ }^{266}$ Anne Sheehan "Dispute Settlement under UNCLOS: The Exclusion of Maritime Delimitation Disputes" (2005) 24 UQLJ 165, 181. See also Erro J Manner "Settlement of Sea-boundary Delimitation Disputes According to the Provisions of the 1982 Law of the Sea Convention" in Jerzy Makarczyk (ed) Essays in International Law in Honour of Judge Manfred Lachs (Maritnus Nijhoff Publisers, The Hague, 1984) 625. For a historical account of some of the difficulties faced in negotiating the procedures governing maritme boundary disputes during UNCLOS III, see Paul C Irwin "Settlement of Maritme Boundary Disputes: An Analysis of the Law of the Sea Negotiations" (1980) 8 (2) ODIL 105.

${ }^{267}$ Ted L McDorman "Ocean Dispute Settlement in the Baltic Sea" in Renate Platzöder and Philomene Verlaan (eds) The Baltic Sea: New Developments in National Policies and International Co-operation (Martinus Nijhoff Publishers, The Hague, 1996) 189, 197.

${ }^{268}$ Douglas M Johnston The Theory and History of Ocean Boundary-Making (McGill-Queen's University Press, Kingston, 1988), 30 [The Theory and History of Ocean Boundary-Making].

${ }^{269}$ The Theory and History of Ocean Boundary-Making, above n 268, 27 and 30.

${ }^{270}$ The Theory and History of Ocean Boundary-Making, above n 268, 28.
} 
maritime boundary delimitation has been enlarged with the establishment of ITLOS as a permanent international tribunal specialising in ocean affairs. ${ }^{271}$

It is submitted that even outside the jurisdictional limits of ICJ and ITLOS, the other dispute settlement mechanisms under the LOSC will have a role to play in maritime boundary delimitation. Since ocean boundary making is a significant factor influencing oceans governance, it is concluded that dispute settlement provisions will contribute to oceans governance.

\section{Strengthening Regimes and Institutions}

There are many institutions existing on international, regional and national levels that are involved in dealing with marine issues governed by the Convention as well as other multilateral agreements. The Convention is "an appropriate legal and institutional framework for global oceans governance", 272 and "presupposes a highly institutionalised world, and its terms encourage the development of international institutions." 273 Assuming that the dispute settlement mechanisms of the LOSC have a central role to play in the institutional structure of oceans governance, it could be said that they have "an important role in designing, maintaining and enforcing the different rights and responsibilities necessary for other institutions to effectively function.",274

The Convention created three new permanent institutions - ITLOS, the Commission on the Limits of the Continental Shelf (CLCS), and the International Seabed Authority (ISA) to assist in the resolution of disputes and to give effect to its provisions. ${ }^{275}$ A number of other "ad hoc institutions" were also created by

\footnotetext{
${ }^{271}$ See Judge Dolliver Nelson, President of ITLOS (Para 14, Statement on the Report of the Tribunal at the Fifteenth Meeting of States Parties to the Convention on the Law of the Sea, New York, 16 June 2005) <http://www.itlos.org/> (last accessed 14 September 2005).

272 Alexander Yankov and Mario Ruivo "An Ocean Assembly" in Peter Bautista Payoyo (ed) Ocean Governance: Sustainable Development of the Seas (United Nations University Press, Tokyo, 1994) 330, 335.

${ }^{273}$ Tullio Treves "The Law of the Sea Convention Ten Years After Entry Into Force: Positive Developments and Reasons for Concerns" in David D Caron and Harry N Scheiber (eds) Bringing New Law to Ocean Waters (Martinus Nijhoff Publishers, Leiden, 2004) 349, 350.

${ }^{274}$ Klaus Decker, Caroline Sage and Milena Stefanova "Law or Justice: Building Equitable Legal Institutions" (2005) The World Bank Working Paper, Report No 33653, 2.

${ }^{275}$ Donald R Rothwell "Building on the Strengths and Addressing the Challenges: The Role of Law of the Sea Institutions" (2004) 35 ODIL 131, 132 ["Building on the Strengths and Addressing the Challenges"]; David Anderson "The International Tribunal for the Law of the Sea" in Malcolm Evans (ed) Remedies in International Law: The Institutional Dilemma (Hart Publishing, Oxford, 1998) 71, 71 .
} 
the Convention for specialised purposes, such as the Annex VII Arbitral Tribunals, and States Parties to the Law of the Sea (SPLOS). ${ }^{276}$ It can be argued that dispute settlement mechanisms can considerably strengthen the position of ISA. ISA may get involved in various marine environmental disputes, since it is a party to exploration and exploitation contracts with mining operators and contractors. ${ }^{277}$ ISA can issue orders to prevent serious harm to the marine environment arising from activities in the Area, ${ }^{278}$ and disapprove areas for exploitation where a significant risk of harm to the environment exists. ${ }^{279}$ However, such decisions are subject to challenge especially under Article 187(c)(ii), whereby the Seabed Disputes Chamber (SDC) of ITLOS may be called upon to adjudicate the dispute. ${ }^{280}$ In such cases, if SDC finds the ISA's decisions reasonable and justified, it could uphold such environmental decisions, and in the process augment marine environmental protection as well as strengthen ISA's stance.

Gold and Petrie have produced an impressive list of international maritime organisations and institutions that are inter-governmental or nongovernmental in nature. ${ }^{281}$ These institutions and organisations cover a wide range of ocean issues. The main types of institutions with related areas of interest as classified by Gold and Petrie into nine broad sectors, are - scientific and technical; economic, political and professional; maritime transport and communication; living resources of the oceans; non-living resources of the oceans; protection of the marine environment; maritime education, research and training; those involved in strategic studies; and other organisations. ${ }^{282}$ Such international organisations operating in the maritime area are often involved in disseminating information, providing support (administrative, logistic or

\footnotetext{
276 "Building on the Strengths and Addressing the Challenges", above n 275, 132.

277 Tullio Treves "The Role of Dispute Settlement Mechanisms in the Protection of the Marine Environment in Cases Concerning Economic Activities in the Sea and Seabed" in The International Bureau of the Permanent Court of Arbitration (ed) International Investments and Protection of the Environment (Kluwer Law International, Boston, 2001) 97, 107 ["The Role of Dispute Settlement Mechanisms in the Protection of the Marine Environment in Cases Concerning Economic Activities in the Sea and Seabed"].

${ }^{278}$ LOSC, art 162(2)(w).

${ }^{279}$ LOSC, art 162(2)(x).

280 "The Role of Dispute Settlement Mechanisms in the Protection of the Marine Environment in Cases Concerning Economic Activities in the Sea and Seabed", above n 277, 107.

${ }^{281}$ Edgar Gold and Christopher Petrie "International Maritime Organizations and Institutions" in Edgar Gold (ed) Maritime Affairs: A World Handbook (2 ed, Longman Group UK Limited, Harlow, Essex, 1991) 36.

${ }^{282}$ Gold and Petrie, above n 281, 36 - 73.
} 
otherwise) and advice in research programs and assessing problems, giving scientific and technical expertise, besides being involved in the rule and policy making process within their own domain of expertise. ${ }^{283}$ Kimball has argued that the legal and intellectual constructs are available, but they need to be bolstered by a good institutional structure spread across global, regional and national levels to meet the current challenges of oceans governance. ${ }^{284}$

Dispute settlement mechanisms under the LOSC could help strengthen some of the above institutions, under suitable circumstances. For example, the role and value of the UN inter-agency expert group, Group of Experts on the Scientific Aspects of Marine Environmental Protection (GESAMP) could be highlighted under dispute settlement procedures under the LOSC. GESAMP is involved inter alia in producing periodic "state of the marine environment" assessment reports. ${ }^{285}$ The assessments, which are primarily designed to inform parties negotiating agreements on dumping, maritime transport of hazardous substances and discharges from ships, could be authoritatively referred to in the dispute settlement process under the LOSC where applicable. Similarly, the recommendations of the International Atomic Energy Agency on safe transport, handling or the suitability of disposal of radioactive wastes at sea could be upheld in a relevant dispute by a dispute settlement body having jurisdiction under the LOSC.

Alex Elferink in addressing the relationship between CLCS and the LOSC dispute settlement mechanisms has convincingly argued that dispute settlement may complement CLCS. ${ }^{286} \mathrm{He}$ asserts that the dispute settlement mechanisms "may have the possibility to clarify the legal framework in which the CLCS has to function." 287 There are divergent views on whether a state's fixing of the outer limit of the continental shelf under Article 76 of the

\footnotetext{
${ }^{283}$ See Edward Miles "On the Role of International Organizations in the New Ocean Regime" in Choon-ho Park (ed) The Law of the Sea in the 1980s (Law of the Sea Institute, University of Hawaii, Honolulu, 1983) 383.

${ }^{284}$ Lee A Kimball "Whither International Institutional Arrangements to Support Ocean Law" (1997) 36 Colum J Transnatl L 307, 307.

${ }^{285}$ GESAMP is jointly funded by the UN, UNEP, FAO, UNESCO/ IOC, WHO, WMO, IMO, and IAEA. For the reports and studies prepared by GESAMP, see $<$ http://gesamp.imo.org/publicat.htm> (last accessed 11 November 2005).

${ }^{286}$ Alex G Oude Elferink "The Continental Shelf Beyond 200 Nautical Miles: The Relationship Between the CLCS and Third Part Dispute Settlement" in Alex G Oude Elferink and Donald R Rothwell (eds) Oceans Management in the 21st Century: Institutional Frameworks and Responses (Martinus Nijhoff Publishers, Leiden, 2004) 107, 121 - 123.

${ }^{287}$ Elferink, above n 286, 123.
} 
Convention is subject to challenge by other states before the dispute settlement mechanisms of the Convention. ${ }^{288}$ Outside such debate, Elferink argues that a court or tribunal can make findings that are of consequence to the procedure involving the CLCS. ${ }^{289}$ For example, a judgment may conclude that an outer limit line is not finally binding on a certain state, since it has not been established in accordance with Article 76 of the Convention. ${ }^{290}$

Provisions have been included in the Convention to involve existing international institutions and organisations in the dispute settlement process through some innovative arrangements and procedures. ${ }^{291}$ Significant roles have been assigned to a few institutions in the functioning of the special arbitration procedure laid down under Annex VIII of the Convention. ${ }^{292}$ The responsibility for the establishment and management of the list of experts for such Special Arbitral Tribunals has been assigned to the Food and Agriculture Organisation (FAO) (fisheries), UNEP (protection and preservation of the marine environment), Intergovernmental Oceanographic Commission (marine scientific research), and International Maritime Organization (navigation and prevention of pollution from vessels and by dumping). ${ }^{293}$ This is the first time that these organisations have been involved in the dispute settlement process, ${ }^{294}$ and it is argued that by according such responsibility to these institutions, the dispute settlement procedures go a long way in strengthening them. Such involvement in the dispute settlement process arguably bolsters the credibility of these institutions and strengthens their authority in their respective field of expertise.

To date, an Annex VIII tribunal has not been utilised. It is hoped that when a request for its establishment is actually made, the outcome of dispute settlement in any of the identified areas would have a significant impact on

\footnotetext{
${ }^{288}$ See Ted L McDorman "The Role of the Commission on the Limits of the Continental Shelf: A Technical Body in a Political World" (2002) 17 IJMCL 301, 317 - 318; Edward Duncan Brown Sea-Bed Energy and Minerals: The International Legal Regime (vol 1, The Continental Shelf, Martinus Nijhoff Publishers, Dordrecht, 1992) 32.

${ }^{289}$ Elferink, above n 286, 121.

${ }^{290}$ Elferink, above n 286, 121.

291 Thomas A Mensah "The Competent International Organizations: Internal and External Changes" in Peter Bautista Payoyo (ed) Ocean Governance: Sustainable Development of the Seas (United Nations University Press, Tokyo, 1994) 278, 280 ["The Competent International Organizations: Internal and External Changes"].

292 "The Competent International Organizations: Internal and External Changes", above n 291, 280.

${ }^{293}$ LOSC, art 2(2) Annex VIII.

${ }^{294}$ The Oceanic Circle: Governing the Seas as a Global Resource, above n 3, 117.
} 
oceans governance. Such a suggestion is fair because the involvement of scientific experts in the dispute settlement process would lead to a justifiable treatment of technical issues in ocean disputes involving the four broad issue areas - fisheries, protection of the marine environment, marine scientific research, and prevention of pollution.

The dispute settlement provisions under the Convention strengthen regimes such as the one on marine environmental protection. The very fact that disputes concerning the interpretation or application of provisions on marine environmental protection can be submitted to one of the dispute settlement bodies under Article 287 goes a long way in strengthening the regime. ${ }^{295}$ It is interesting to note in this regard, that there are no limitations on the application of compulsory and binding dispute settlement procedures to disputes concerning the protection and preservation of the marine environment. ${ }^{296}$ Since institutions and international bodies are often involved in some decision making process of some sort or the other, dispute settlement bodies may also have opportunities to review their decisions. ${ }^{297}$ These are some of the possible ways in which the dispute settlement mechanisms could strengthen regimes and institutions both under and outside the LOSC.

\section{Interpreting and Clarifying the Law and Developing Rules}

A court must be trusted to do what it does best - interpret the law. Since a legal system cannot settle all social issues simply by means of substantive rules, dispute settlement procedures are necessary to interpret and enforce those rules when previously unanswered questions arise. ${ }^{298}$ They must clarify the law,

\footnotetext{
${ }^{295}$ See Tullio Treves "Dispute-Settlement Clauses in the Law of the Sea Convention and Their Impact on the Protection of the Marine Environment: Some Observations" (1999) 8 (1) RECIEL 6,6 .

${ }^{296}$ Lee A Kimball "The United Nations Convention on the Law of the Sea: A Framework for Marine Conservation" in IUCN The Law of the Sea: Priorities and Responsibilities in Implementing the Convention (IUCN, Gland, Switzerland, 1995) 1, 28.

${ }^{297}$ See generally, Kaiyan Homi Kaikobad The International Court of Justice and Judicial Review: A Study of the Court's Powers with Respect to Judgments of the ILO and UN Administrative Tribunals (Kluwer Law International, The Hague, 2000).

${ }^{298}$ Mary Ellen O'Connell "Introduction" in Mary Ellen O'Connell (ed) International Dispute Settlement (Dartmouth Publishing Company, Hants, England, 2003) xxvi.
} 
eliminate ambiguities and give guidance for future behaviour of states parties. ${ }^{299}$ As Budislav Vukas puts it succinctly, "the crux of [their] role is to resolve the dispute between the parties on the basis of a correct interpretation of the applicable legal rules." ${ }^{\prime 300}$ Generally speaking, an international tribunal will be mostly involved in interpreting the law in its dispositive role where it is actually involved in resolving disputes. Functioning within the ambit of this role, a tribunal may be charged primarily with the development of rules, or simply ironing out legal disputes about ocean space. These sub-functions will be briefly discussed in the following paragraphs.

Arguing for a new integrated system of oceans governance, Jackson Davis asserts that effective global oceans governance demands countries to surrender some element of their traditional sovereignty to international organisations. ${ }^{301}$ It is submitted here that, if countries are willing to relinquish such small measures of sovereignty, and bring unresolved questions from grey areas of the law before international tribunals, the resulting clarification of the law could have a positive impact upon global oceans governance. On the same issue of sovereignty, one of the most distinguished writers on oceans governance, Elisabeth Borgese has commented that the dispute settlement provisions of the Convention signify one of its positive aspects. ${ }^{302}$ She suggested that the dispute settlement under the Convention does not merely limit state sovereignty, but "transforms, and transcends" $" 303$ it.

This of course is not to ask for a legislative or law-making function to be accorded to international tribunals but to enable them to interpret the law and develop or modify existing rules in the context of changed circumstances since their original creation. Such changed circumstances could result from factors like technological development leading to advanced exploitation of the oceans or

\footnotetext{
${ }^{299}$ See generally Louis B Sohn "Peaceful Settlement of Disputes" in Mark W Janis (ed) International Courts for the Twenty-First Century (Martinus Nijhoff Publishers, Dordrecht, 1992) 3, 3- 5 ["Peaceful Settlement of Disputes"].

300 "Possible Role of the International Tribunal for the Law of the Sea in Interpretation and Progressive Development of the Law of the Sea", above n 23, 97.

${ }^{301}$ W Jackson Davis "The Need for a New Global Ocean Governance System" in Jon M Van Dyke, Durwood Zaelke and Grant Hewison (eds) Freedom for the Seas in the 21st Century: Ocean Governance and Environmental Harmony (Island Press, Washington DC, 1993) 147, 166.

${ }^{302}$ Elisabeth Mann Borgese "Global Civil Society: Lessons from Ocean Governance" (1999) 31 Futures 983, 985 ["Global Civil Society: Lessons from Ocean Governance"].

303 "Global Civil Society: Lessons from Ocean Governance", above n 302, 985 (emphasis in original).
} 
alterations in the basic marine environment. ${ }^{304}$ The development of rules and norms can lead to a clarification in the law, the observance of which would lead to better oceans governance. In this regard, it is worthwhile to note that international dispute settlement involves "more than the simple application of facts to law [and extends to] the elaboration of norms, thereby filling gaps in the law.",305

Tim Stephens has stressed the importance of judicial decisions in environmental oceans governance: $:^{306}$

The jurisprudence of respected international courts may greatly assist in the development of the normative order. Judicial analysis and exposition is crucial in areas such as international environmental law which is still in a formative stage of development.

Another commentator has asserted that the international judicial bodies "have the authority to establish new principles, as well as clarify the legitimacy of rules of customary international law and peremptory ... norms. ${ }^{, 307}$ It can be argued that one of the commonly acknowledged public functions of international dispute settlement could be perceived in the role of standing international tribunals such as ICJ and ITLOS in the development of the law of the sea. ${ }^{308}$ Robert Jennings, the former President of ICJ has referred to this law development function of ICJ to be its "seminal function", and especially crucial in the field of international environmental law. ${ }^{309}$ The role of international

\footnotetext{
${ }^{304}$ See Colin B Picker "A View from 40,000 Feet: International Law and the Invisible Hand of Technology" (2001) 23 Cardozo L Rev 149, 165 - 170. Picker describes inter alia, the impact of technology on the law of the sea generally and the international law of fisheries.

${ }^{305}$ Craik, above n 140, 577.

${ }^{306}$ Tim Stephens “A Paper Umbrella Which Dissolves in the Rain? Implications of the Southern Bluefin Tuna Case for the Compulsory Resolution of Disputes Concerning the Marine Environment under the 1982 LOS Convention" (2001) 6 APJEL 297, 304.

307 Dionysia - Theodora Avgerinopoulou "The Role of the International Judiciary in the Settlement of Environmental Disputes and Alternative Proposals for Strengthening International Environmental Adjudication" in Global Environmental Governance: The Post-Johannesburg Agenda (Yale Centre for Environmental Law and Policy, New Haven, 2003) 4, available at $<$ http://www.yale.edu/gegdialogue/docs/dialogue/oct03/papers/Avgerinopoulou.pdf $>\quad$ (last accessed 6 December 2005).

${ }^{308}$ Craik, above n 140, 563.

309 Robert Jennings "Need for Environmental Court?" (1992) 22 Envtl Poly \& L 312, 313. See generally Stephen M Schwebel "The Contribution of the International Court of Justice to the Development of International Law" in Wybo P Heere (ed) International Law and The Hague's 750th Anniversary (TMC Asser Press, The Hague, 1999) 405; Hugh Thirlway "The Proliferation of the International Judicial Organs and the Formation of International Law" in Wybo P Heere (ed) International Law and The Hague's 750th Anniversary (TMC Asser Press, The Hague, 1999) 433.
} 
dispute settlement bodies in the development of the law of the sea has been elaborately asserted in the past. ${ }^{310}$ Queneudec has argued that the main ways in which international jurisprudence has shaped the development of the law of the sea are through: "the delimitation of territorial and internal waters; the coastal state's jurisdiction beyond the territorial sea; the rights of navigation; the jurisdiction over shipping; the delimitation of maritime boundaries between States."311 Though Queneudec's arguments were based on the developments prior to the creation of the LOSC, it can be argued that the dispute settlement machinery under the Convention can go a long way in clarifying the law, given the many ambiguities in the LOSC. ${ }^{312}$

The role of dispute settlement in interpreting the law and developing rules becomes pertinent in light of the fact that all agreements including the LOSC need to be interpreted, applied to specific fact situations and elaborated to remove ambiguities and address newly emergent issues. ${ }^{313}$ Legal dispute settlement institutions can help in oceans governance by tackling problems arising out the application and gradual evolution of the LOSC in situations that were difficult to anticipate at the time of drafting. ${ }^{314}$

\section{E $\quad$ Facilitating Co-operation}

The Convention recognises that without international co-operation, especially in the areas of fisheries and environmental protection, the benefits guaranteed to states parties cannot be achieved. ${ }^{315}$ Human boundaries do not

\footnotetext{
310 See Jean-Pierre Queneudec "The Role of the International Court of Justice and Other Tribunals in the Development of the Law of the Sea" in Alfred H A Soons (ed) Implementation of the Law of the Sea Convention through International Institutions (Law of the Sea Institute, University of Hawaii, Honolulu, 1990) 574.

${ }^{311}$ Queneudec, above n 310, 576 - 584.

312 See Queneudec, above n 310, 592.

${ }^{313}$ Abbott and Snidal, above n 135, 430.

${ }^{314}$ Abbott and Snidal, above n 135, 430 and 434.

315 For example, art 118 and 197 deal with co-operation of states in the conservation and management of living resources, and co-operation on a global or regional basis for the protection and reservation of the marine environment, respectively. See also Nienke van der Burgt "The 1982 United Nations Convention on the Law of the Sea and its Dispute Settlement Procedure" (2005) 6 (1) Griffin's View 18, 34; Yves L Fortier "From Confrontation to Cooperation on the High Seas: Recent Developments in International Law Concerning the Conservation of Marine Resources" in Nisuke Endo and others (eds) Liber Amicorum Judge Shigeru Oda (vol 2, Kluwer Law International, The Hague, 2002) 1377.
} 
reflect the transboundary nature of international marine issues such as fisheries and pollution. Highly migratory and straddling fish stocks and pollutants that spread across vast tracts of ocean without respect to ocean zones need to be managed or dealt with on the anvil of international co-operation aiming for an integrated approach to oceans governance. ${ }^{316}$

Co-operation is one of the cornerstones of most governance regimes around the world, and occupies a prominent position in global oceans governance. Take for example the governance of the international shipping industry as a part of the bigger picture of global oceans governance. Zacher and Sutton have argued that the success of most international regimes such as that of shipping is grounded in international co-operation inspired by states' mutual interests as against the dictate of powerful nations. ${ }^{317}$

Richard Bilder has supported and advanced the view that the dispute settlement system in the LOSC was designed to gradually build on the confidence of the states parties to it. ${ }^{318}$ A few unresolved issues between states, arguably of little significance cannot do much to undermine the cause of good oceans governance, but an accumulation of such issues eventually could lead to a reduction in mutual trust between nations and affect compliance functions. ${ }^{319}$

In the process of facilitating co-operation between disputant states, ${ }^{320}$ the dispute settlement mechanisms under the LOSC could also help foster friendly relations between them. John Jackson has argued that the ability of a dispute settlement procedure to assist in the friendly relations between states is an important benchmark for the evaluation of the performance of dispute settlement mechanisms. ${ }^{321}$

In this regard, it needs to be pointed out that the LOSC dispute settlement mechanisms range from formal dispute settlement options before permanent

\footnotetext{
${ }^{316}$ On the need for an integrated approach to oceans governance, see "Zonal and Integrated Management Approaches to Ocean Governance, above n 39.

${ }^{317}$ Mark W Zacher and Brent A Sutton Governing Global Networks: International Regimes for Transportation and Communications (Cambridge University Press, Cambridge, 1996) 36.

${ }^{318}$ Richard Bilder "Commentary" in Thomas A Mensah (ed) Ocean Governance: Strategies and Approaches for the $21^{\text {st }}$ Century (The Law of the Sea Institute, University of Hawaii, Honolulu, 1994) 256, 258.

${ }^{319}$ Peterson, above n 208, 124 .

${ }^{320}$ For a discourse on the co-operational duties in international dispute settlement, see Anne Peters "International Dispute Settlement: A Network of Cooperational Duties" (2003) 14 (1) EJIL 1.

${ }^{321}$ John H Jackson "GATT as an Instrument for the Settlement of Trade Disputes" (1967) 61 Am Socy Intl L Proc 144, 153.
} 
forums such as ITLOS and ICJ to less formal Annex VII Arbitral Tribunals and Conciliation Commissions. ${ }^{322}$ The dispute settlement provisions allow great flexibility to state parties in the way in which they choose to settle their disputes, as long as the means are peaceful. ${ }^{323}$ With such freedom given to states in resolving their disputes, and in providing for such a wide range of dispute settlement options, the dispute settlement provisions of the LOSC have paved the way for developing friendly relations between states. It is argued that in assisting nations develop friendly relations the dispute settlement mechanisms of the LOSC can advance the cause of good oceans governance.

\section{F Reducing Tensions, Ironing Out Problems, Maintaining Peace and Security}

The LOSC dispute settlement mechanisms in their traditional role of peacefully settling disputes between states also make a major contribution to oceans governance. Craik has suggested that the insistence in the Charter of the $\mathrm{UN}$ on the peaceful settlement of disputes can be interpreted as a public function of dispute settlement in the maintenance of peace in the world. ${ }^{324}$

The shared cost of maintaining a standing international tribunal such as ITLOS as an important tool for oceans governance is certainly far below the cost that could accrue to a nation from a single day of war developed from an ocean related dispute. The dispute settlement provisions of the Convention having been created to ensure that world peace is not disturbed by an escalation of an ocean dispute play a significant role in oceans governance. ${ }^{325}$ Confidence in impartial, efficient and cost effective dispute settlement mechanisms can help states settle their differences "with minimum disruption and without unnecessary loss of time and resources." 326 Sohn has argued that recourse to formal dispute settlement options could also help countries avoid political costs that are incurred on

\footnotetext{
${ }^{322}$ LOSC, arts 284 and 287.

${ }^{323}$ LOSC, arts 279 and 280.

${ }^{324}$ Craik, above n 140, 563.

${ }^{325}$ See Sohn "The Role of Dispute Settlement in Ocean Governance", above n 31, 245.

${ }^{326}$ Thomas A Mensah "The Role of Peaceful Dispute Settlement in Contemporary Ocean Policy and Law" in Davor Vidas and Willy Østreng Order for the Oceans at the Turn of the Century (Kluwer Law International, The Hague, 1999) 81, 82.
} 
account of a confrontation arising from a dispute. ${ }^{327}$ Quite understandably, states would be more willing to end a confrontation on being dictated by the decision of a disinterested tribunal rather than brute force. ${ }^{328}$

It is submitted that dispute settlement has an important facilitative role to play in the peaceful settlement of disputes. International third-party adjudication, for example could be used "to fully resolve a dispute; to clarify legal principles that will assist countries in negotiating a resolution; or to deal with one aspect of a much larger dispute." 329 Adjudication can take on a facilitative role in pronouncing a decision that would assist the disputants in reaching a negotiated solution or a dispositive role, which would see it actually resolving the dispute. $^{330}$ Similarly, non-adjudicatory processes such as mediation and conciliation that are equally encouraged under the LOSC dispute settlement provisions, "involve the assignment of explicitly facilitative roles contemplating the need for future negotiations between the parties."331

A decision by an international tribunal operating under Part XV of the Convention could do more than iron out problems between or among the main parties involved in the dispute. An international decision on ocean law, as Sohn suggests, could settle many future problems as states not directly involved in a case would possibly follow the tribunal's decision in similar situations and could avoid defending themselves before the tribunal. ${ }^{332}$ Borgese has similarly asserted that on a regional scale, the settlement of disputes could make an important contribution to maintaining security by utilising Part XV of the Convention, particularly Annexes VII and VIII. ${ }^{333}$

There is another significant way in which the LOSC dispute settlement mechanisms help maintain world peace, though without actually playing an active part in the process. J G Merrills, a distinguished authority on international

\footnotetext{
327 "The Importance of the Peaceful Settlement of Disputes Provisions", above n 150, 275.

328 "The Importance of the Peaceful Settlement of Disputes Provisions", above n 150, 275.

329 Ted L McDorman "The Search for Resolution of the Canada - France Ocean Dispute Adjacent to St. Pierre and Miquelon" (1994) 17 (1) Dal L J 35, 53.

${ }^{330}$ The Theory and History of Ocean Boundary-Making, above n 268, 29, 237 - 238; Ted L McDorman "The Dispute Settlement Regime of the Straddling and Highly Migratory Fish Stocks Convention" (1997) 35 Can YIL 57, 62; Peter Örebech, Ketill Sigurjonsson and Ted McDorman "The 1995 United Nations Straddling and Highly Migratory Fish Stocks Agreement: Management, Enforcement and Dispute Settlement” (1998) 13 (2) IJMCL 119, 133.

${ }^{331}$ The Theory and History of Ocean Boundary-Making, above n 268, 30.

332 "The Importance of the Peaceful Settlement of Disputes Provisions", above n 150, 275.

${ }^{333}$ The Oceanic Circle: Governing the Seas as a Global Resource, above n 3, 160.
} 
dispute settlement has commented that the knowledge of their sheer existence and their potential to be involved in ocean dispute resolution "discourages unreasonableness and so acts as a means of dispute avoidance" 334 among states. ${ }^{335}$ In this regard, is meaningful to quote Ian Sinclair's comments on the dispute settlement provisions of the Vienna Convention on the Law of Treaties: ${ }^{336}$

\begin{abstract}
[T]he chief value of the automatic procedures for settlement of disputes ... lies not in their precise content but in their mere existence. Paradoxically, the less they are utilised the more effective they will be.... What is important - what is indeed crucial - is that there should always be in the background, as a necessary check upon the making of unjustified claims, or upon the denial of justified claims, automatically available procedures for the settlement of disputes.
\end{abstract}

Summing up, it is seen that the objective decisions of Part XV dispute settlement tribunals can have far-reaching effects in reducing tensions between states, and ironing out specific problems in oceans space. Even their very presence and availability can lead to dispute avoidance and hence help preserve peace in the world.

\title{
G Ensuring Compliance with, and Enforcement of, International Law
}

The former Minister of Foreign Affairs and Trade of New Zealand, Hon Phil Goff has stressed the importance of effective dispute settlement and the role of specialist judicial bodies in international governance as enforcement mechanisms that "give teeth to...international commitments." $337 \mathrm{He}$ has called international dispute settlement mechanisms as one of the "fundamental aspects underpinning international legal order" ${ }^{338}$ that help peacefully redress inter-state grievances. The above comments are equally applicable to the LOSC dispute

\footnotetext{
${ }^{334}$ J G Merrills International Dispute Settlement (3 ed, Cambridge University Press, New York, 1998) 173 [International Dispute Settlement].

${ }^{335}$ See "Building on the Strengths and Addressing the Challenges", above n 275, 148.

${ }^{336}$ Ian Sinclair The Vienna Convention on the Law of Treaties (2 ed, Manchester University Press, Manchester, 1984) 235.

${ }^{337}$ Hon Phil Goff "International Institutions and Governance: A New Zealand Perspective" in International Governance And Institutions: What Significance For International Law? Proceedings of the Eleventh Annual Conference of the Australian and New Zealand Society of International Law (Wellington, 2003) 1, 4.

${ }^{338}$ Goff, above n 337,1 .
} 
settlement provisions that are designed not just to serve states but even international organisations and private entities in certain circumstances.

On the broader spectrum of global environmental governance, it has been said that dispute settlement has a key role to play through vehicles such as public interest litigation to defend environmental rights and to clarify and enforce laws. ${ }^{339}$ It has been long established that the environmental governance regimes of the world are scattered and fragmented leaving large jurisdictional gaps that make way for great environmental damage. ${ }^{340}$ Scholars who have advocated for the creation of a centralised "global environment organisation" or a "global environmental mechanism" have envisioned the presence of a dispute settlement mechanism with the ability to settle disputes within environmental agreements and vis-à-vis other global governance regimes. ${ }^{341}$ Just as the inclusion of dispute settlement mechanisms in environmental governance regimes can be seen to be an obvious strength, weakness in such regimes is manifest by their absence. In a regional context it has been shown that the lack of a dispute resolution mechanism within the Association of Southeast Asian Nations has been a key limitation and barrier to its effective environmental governance. ${ }^{342}$

It can be argued that the dispute settlement provisions of the LOSC could help states significantly reduce their transaction costs by providing a reliable option against the prospect of renegotiation, persuasion or coercion. ${ }^{343}$ Not only could the dispute settlement provisions aid in the enforcement of the law of the sea at low political cost but would also sublimate political conflicts into legal

\footnotetext{
339 Barbara Gemmill and Abimbola Bamidele-Izu "The Role of NGO's and Civil Society in Global Environmental Governance" in Daniel C Esty and Maria H Ivanova (eds) Global Environmental Governance: Options \& Opportunities (Yale School of Forestry \& Environmental Studies, New Haven, 2002) 77, 95.

${ }^{340}$ The Ocean Our Future, above n 194, 139; Institute on Governance "Uncharted Waters: The Need for Integrated Oceans Governance" (April 2005) News, News, News $<$ http://www.iog.ca/news/apr2005.pdf $>$ (last accessed 19 October 2005). See also Lennox Hinds "Oceans Governance and the Implementation Gap" (2003) 27 Marine Policy 349.

341 Daniel C Esty and Maria H Ivanova "Revitalizing Global Environmental Governance: A Function-Driven Approach" in Daniel C Esty and Maria H Ivanova (eds) Global Environmental Governance: Options \& Opportunities (Yale School of Forestry \& Environmental Studies, New Haven, 2002) 181. See also See Palmer, above 132, $282-283$.

${ }^{342}$ Kheng Lian Koh and Nicholas A Robinson "Regional Environmental Governance: Examining the Association of Southeast Asian Nations (ASEAN) Model" in Daniel C Esty and Maria H Ivanova (eds) Global Environmental Governance: Options \& Opportunities (Yale School of Forestry \& Environmental Studies, New Haven, 2002) 101, 110 - 117. It has been argued that despite a medley of policies on sustainable development, resolutions, plans of action and programs, implementation of ASEAN agreements is often impeded when dispute resolution becomes a challenge.

${ }^{343}$ See Abbott and Snidal, above n 135, 431.
} 
arguments and finally lead to their resolution. ${ }^{344}$ The value of the dispute settlement mechanisms of the Convention in the elaboration, application and enforcement of international law of the sea had been recognised early on as Part XV began to take shape. ${ }^{345}$ In this regard, Riphagen, one of the leading delegates at UNCLOS III had described the dispute settlement options as "mechanisms of supervision" $" 346$ of the law of the sea.

In terms of general global environmental governance, it has been argued that self-enforcing treaties such as the LOSC with its dispute settlement provisions are effective ways of managing global commons such as the oceans. ${ }^{347}$ In a seminal paper in 1968, Garrett Hardin argued that human users of the commons are caught in an inevitable process leading them to destroy the resources they depend on, and that mutual coercion is the best means to avoid the dangers resulting from this process. ${ }^{348}$ It can be argued that such coercion on the international level could come from the decisions of dispute settlement bodies, to which disputes on common pool resources would be submitted with due state consent. The importance of effective dispute settlement mechanisms has been stressed in identifying some of the measures required to address the present shortcomings in international environmental governance ${ }^{349}$ and fisheries governance. ${ }^{350}$

Again, it has been argued that resource management of the global commons requires "unanimous agreement as a collective-choice rule" that is

\footnotetext{
${ }^{344}$ See Abbott and Snidal, above n 135, 431.

${ }^{345}$ See "The Role of Dispute Settlement in Ocean Governance", above n 31, 235 - 236.

${ }^{346}$ W Riphagen "Mechanisms of Supervision in the Future Law of the Sea" in Frits Kalshoven, Pieter Jan Kuyper and Johan G Lammers (eds) Essays on the Development of the International Legal Order (Sijthoff \& Noordhoff, Alphen aan den Rijn (The Netherlands), 1980) 115, 115.

${ }^{347}$ Lincoln P Bloomfield "Enforcing Rules in the International Community: Governing the Ungovernable?" in Issues in Global Governance: Papers Written for the Commission on Global Governance (Kluwer Law International, London, 1995) 219, 240 - 241.

${ }^{348}$ Garrett Hardin "The Tragedy of the Commons" (1968) 162 Science 1243. For a collection of other essays that express a similar point of view, see Garrett Hardin and John Baden (eds) Managing the Commons (W H Freeman, San Francisco, 1977). Later in 1998, Hardin modified his argument slightly by qualifying the noun "commons" with the adjective "unmanaged" and asserted that the unmanaged commons, as against the managed commons are destined to ruin. See Garrett Hardin "Extensions of 'The Tragedy of the Commons" " (1998) 280 Science 682.

${ }_{349}$ Philippe Roch and Franz Xaver Parrez "International Environmental Governance: The Strive Towards a Comprehensive, Coherent, Effective and Efficient International Environmental Regime" (2005) 16 Colo J Intl Envtl L \& Poly 1, 21.

350 See Rosemary Gail Rayfuse Non-Flag State Enforcement in the High Seas Fisheries (Maritinus Nijhoff Publishers, Leiden, 2004) 366 [Non-Flag State Enforcement in the High Seas Fisheries].
} 
basically achieved through "voluntary assent to negotiated treaties." 351 Also, the need to have conflict resolution mechanisms as a part of the adaptive governance of complex systems such as the oceans has also been stressed. ${ }^{352}$

William Davey has argued that one of the chief functions of a dispute settlement system is to stop the violation in the case of an alleged rule violation and compel compliance. ${ }^{353}$ The LOSC embodies a vast corpus of laws and rules in its 320 Articles and nine annexes that states parties must abide by. With every chance for a violation anticipated by the framers of the LOSC, the dispute settlement provisions in it were designed to ensure that the differences that could arise between parties as a result of violations or more generally with the interpretation and application of the Convention could be settled in a peaceful manner. ${ }^{354}$ Of course, there are quite a few exclusions built into the Convention that limit the scope of compulsory dispute settlement. ${ }^{355}$

States ratifying the LOSC are required to ensure that their domestic laws are attuned to the provisions of the LOSC. ${ }^{356}$ However, there is every chance that a state ratifying the LOSC interprets its provisions in a certain way that is not intended in the Convention, and formulates its municipal law in a way that it comes into conflict with the international law. Such nature of conflict has been rightly deemed as a major obstacle in oceans governance. ${ }^{357}$ Dispute settlement provisions of the LOSC can be effective in this regard, and could point out any areas of conflict between domestic laws and the established international law of the sea. It can be hoped that following such international exposure of inconsistency of domestic laws with the provisions of the LOSC, the state complained against would bring its laws in conformity with the Convention's provisions. It can even be expected that other states with similar domestic laws

\footnotetext{
351 Elinor Ostrom and others "Revisiting the Commons: Local Lessons, Global Challenges" (1999) 284 Science 278.

352 Thomas Dietz, Elinor Ostrom and Paul C Stern "The Struggle to Govern the Commons" (2003) 302 Science 1907, 1909. See also Paul C Stern and others "Knowledge and Questions After 15 Years of Research" in Elinor Ostrom and Others (eds) The Drama of the Commons (National Academy Press, Washington DC, 2002) 445, 471.

${ }^{353}$ William Davey "Dispute Settlement in GATT" (1987) 11 Fordham Intl L J 51, 67 - 68.

354 See Thomas A Mensah "The Dispute Settlement Regime of the 1982 United Nations Convention on the Law of the Sea" (1998) 2 Max Planck Yrbk UN L 307, 307 - 308.

${ }^{355}$ LOSC, arts 297 - 299. For a detailed discussion, see Klein, above n 265, 125 - 315.

${ }^{356}$ Ocean Governance and the United Nations, above n 20, 33.

${ }^{357}$ Ocean Governance and the United Nations, above n 20, 33.
} 
not in harmony with the Convention would be urged to carry out amendments to bring them in line with the LOSC's provisions.

\section{H Management of Multiple Ocean Use Conflicts}

The LOSC was drafted and negotiated with a clear understanding of the wide range of uses for which the oceans could be utilised as well as an anticipation that the list of ocean uses would only increase over time. ${ }^{358}$ Broadly speaking, the main uses that the sea finds in human life today include the following. ${ }^{359}$

- $\quad$ Fishing

- $\quad$ Surface navigation

- Underwater navigation

- Waste disposal and transportation

- $\quad$ Recreational uses

- $\quad$ Military uses

- $\quad$ Offshore port facilities

- Offshore petroleum and natural gas establishments

- $\quad$ Submarine pipelines and cables

- Construction and operation of artificial islands, structures, platforms and installations

- $\quad$ Overflight

- $\quad$ Marine scientific research

- Archaeological research

- $\quad$ Seabed mining

- Exploitation of the nonliving resources of the water column

- $\quad$ Energy generation from water, winds, currents

- $\quad$ Undersea tunnelling

- $\quad$ Broadcasting

${ }^{358}$ International Law and Ocean Use Management, above n 77, 239.

${ }^{359}$ International Law and Ocean Use Management, above n 77, 239. 
In the historical perspective, ocean uses were relatively few and uncomplicated but since the end of the Second World War, rapid developments in technology and population growth have led to increasing pressure on the oceans. ${ }^{360}$ These pressures have been exerted through the traditional uses of seas as well as the newly emergent ones. Oceans governance through the history of humankind has witnessed a plethora of change and has been marked by varying importance being assigned to new and existing issues and imperatives. Oceans governance has come a long way since the time when navigation was the focus of the law of the sea, to a time of resource allocation and exploitation of oceanic wealth, and finally to a time of maritime security and threats to it. ${ }^{361}$ These threats have come to include a wide variety of different phenomena such as terrorism, military threats, drug trafficking, illegal immigration, natural or human induced catastrophes as well as conflicts over marine spaces or resources. ${ }^{362}$

UNCLOS III strove hard to accommodate many such emerging imperatives along with the existing ones, identifying ongoing and potential conflicts. ${ }^{363}$ It was clearly envisaged during UNCLOS III that the multiplicity of ocean usage would only grow with time and legal provisions had to be made to accommodate present and future uses as far as possible. ${ }^{364}$ In light of the actual

\footnotetext{
${ }^{360}$ Ross Eckert "Ocean Enclosures: A Better Way to Manage Marine Resources" in Robert L Friedheim (ed) Managing Ocean Resources: A Primer (Westview Press, Boulder, Colorado, 1979) 91,92 .

${ }^{361}$ For some interesting observations on the change in international focus from economic to security issues in oceans governance, see Suarez de Vivero and Rodriguez, above n 87.

${ }^{362}$ Suarez de Vivero and Rodriguez, above n 87, 187.

${ }^{363}$ For a comprehensive study in this regard, see Geir Ulfstein "The Conflict Between Petroleum Production, Navigation and Fisheries in International Law" (1988) 19 ODIL 229. See also, Ian Townsend Gault "The Impact of Offshore Petroleum Regimes on Other Sea Users: The North Sea and North America" in Douglas M Johnston and Norman G Letalik (eds) in The Law of the Sea and Ocean Industry: New Opportunities and Restraints (Law of the Sea Institute, University of Hawaii, Honolulu, 1983) 420; John Norton Garrett "Hydrocarbons on the Continental Margins: Some of the Issues Addressed in the UNCLOS III Negotiations" in Douglas M Johnston and Norman G Letalik (eds) in The Law of the Sea and Ocean Industry: New Opportunities and Restraints (Law of the Sea Institute, University of Hawaii, Honolulu, 1983) 411. For a perspective on the conflicts between the submarine cable industry and other marine industries, especially the fishing industry, see Scott Coffen-Smout and Glen J Herbert "Submarine Cables: A Challenge for Ocean Management" (2000) 24 Marine Policy 441.

${ }^{364}$ For some interesting discussions on multiple use oceans governance at the time of the Conference, see Timothy M Hennessey "Multiple Uses of International Marine Resources: Theoretical Considerations" in Douglas M Johnston and Norman G Letalik (eds) in The Law of the Sea and Ocean Industry: New Opportunities and Restraints (Law of the Sea Institute, University of Hawaii, Honolulu, 1983) 34; Tullio Treves "Accommodation of Multiple Uses of the Sea in International Law, With Special Reference to the Mediterranean" in Douglas M Johnston and Norman G Letalik (eds) in The Law of the Sea and Ocean Industry: New Opportunities and Restraints (Law of the Sea Institute, University of Hawaii, Honolulu, 1983) 51; Alastair D Couper and H D Smith "The North Sea: Bases for Management and Planning in a
} 
and potential development of conflict situations often arising from the closely related nature of the oceans and overlapping multiplicity of oceans usage, the LOSC has stressed the need for states to respect the rights of other states while exercising their own rights. ${ }^{365}$ With a necessity felt to ensure the accommodation of all needs, amplified by the inherent ambiguity in various parts of the Convention, the dispute settlement provisions were incorporated. ${ }^{366}$ It was hoped that dispute settlement mechanisms, together with state practice, would help define priorities in ocean uses and clarify the Convention's stipulations in particular circumstances. $^{367}$

It is submitted that the dispute settlement machinery under the LOSC can have an important role to play in multiple ocean use conflicts. The nature of disputes emerging from the conflicting uses and interests in the oceans often precludes political consensus that is desirable for bold exercises in institutional innovation. ${ }^{368}$ Under circumstances where states find themselves facing a deadlock over multiple ocean use management, dispute settlement forums that exist or that may be created under the LOSC, can help find objective solutions to seemingly non-negotiable conflicts based on legal and equitable criteria.

\section{CONCLUSIONS}

This chapter began with an enquiry into the definitions of governance in part I and found a wide disparity in the available definitions that are not easy to reconcile. There is no straightforward definition of governance, though there are common features that the definitions embrace. These are: (i) robust institutions for common good, (ii) rules, policies, processes and powers, (iii) effective implementation, enforcement, exercise and problem solving (iv) stability and performance and (v) good decision making in consideration of diverse interests.

Part II enquired into the definitions of oceans governance to understand the nature and scope of oceans governance. It was found that oceans governance

\footnotetext{
Multi-State Sea Region" in Douglas M Johnston and Norman G Letalik (eds) in The Law of the Sea and Ocean Industry: New Opportunities and Restraints (Law of the Sea Institute, University of Hawaii, Honolulu, 1983) 63.

${ }^{365}$ See, for instance, LOSC arts 56(2) and 78(2).

${ }^{366}$ International Law and Ocean Use Management, above n 77, 240.

${ }^{367}$ International Law and Ocean Use Management, above n 77, 240.

${ }^{368}$ The Ocean Our Future, above n 194, 140.
} 
refers to processes as well as outcomes directed at regulating various human actions with respect to the oceans. The common features between governance in general and oceans governance were that both required norms and rules, accommodating diverse issues and robust institutions operating at various levels. Part III sought to establish the various links between governance, law and dispute settlement. It was shown that laws are an integral part of governance, although opinions were divided on the role of dispute settlement in governance, particularly formal procedures. Part IV was an enquiry into the possible connections between oceans governance, law and dispute settlement. Just like the links between governance, law and dispute settlement as seen in part III, this part revealed consensus among scholars and experts about the roles of law and dispute settlement in oceans governance. It is found that there exists considerable potential for dispute settlement mechanism under the LOSC to contribute to oceans governance, and this was analysed under eight individual heads. 


\section{CHAPTER 3}

\section{INVOKING THE DISPUTE SETTLEMENT PROCEDURES}

The present chapter summarises the dispute settlement provisions in the Convention, and demonstrates the extent to which they have been utilised so far. This is necessary in the overall scheme of the thesis, in order to analyse the actual role that dispute settlement has played in oceans governance to date. The object of this chapter is to bring out the elements of the available jurisprudence that have contributed most to oceans governance so far. This chapter provides the background for chapter 5, where the potential and actual roles of dispute settlement in oceans governance are tallied together.

Part I of the chapter argues about the merits of having dispute settlement provisions in the Convention, and is followed by an outline of the dispute settlement provisions. Section A of part II analyses the prompt release cases before ITLOS to date, and finds that bonds (the most debatable issue in prompt release proceedings) ${ }^{369}$ sought by detaining states have been "discounted" considerably in every case. This feature is seen as a disturbing development in the Tribunal's jurisprudence with severe repercussions extending to various areas in oceans governance. The following subsections bring out some other issues emerging from or connected to the Tribunal's prompt release jurisprudence that have a beneficial or detrimental influence on oceans governance.

Part II of this chapter screens the interim relief provided under provisional measures cases at ITLOS, and the developments that follow in the final settlement of the disputes. This part reveals a largely beneficial role that dispute settlement has played in oceans governance. Part III describes the disputes that are pending for settlement under the Convention. Part IV of the chapter briefly acknowledges the constructive effect of the expeditious handling of disputes by ITLOS.

In conclusion, it is found that though there are certain issues in the jurisprudence that go against the cause of good oceans governance, the overall

\footnotetext{
${ }^{369}$ Yoshifumi Tanaka "Prompt Release in the United Nations Convention on the Law of the Sea: Some Reflections on the ITLOS Jurisprudence" (2004) 51 (2) NILR 237, 239.
} 
influence of dispute settlement on oceans governance has been beneficial. It is hoped that the future will see more beneficial impacts on oceans governance from dispute settlement.

\section{INTRODUCTION TO THE DISPUTE SETTLEMENT PROVISIONS IN THE CONVENTION}

UNCLOS III had as its basic objective the adoption of a comprehensive Law of the Sea Convention. ${ }^{370}$ It was therefore the intention of the negotiators and the drafters of the LOSC to establish a "constitution" 371 for the oceans that would find universal acceptance. The LOSC, besides providing for a legal regime for manifold uses and aspects of the oceans, also contains one of the longest and most intricate dispute settlement provisions ever drafted. ${ }^{372}$ Some of the main concerns felt during UNCLOS III for having dispute settlement procedures in the LOSC, have been discussed in chapter 2. Like many of the provisions in the Convention, the negotiations on the dispute settlement part took place in informal meetings rather than in open debates with formal records, and

\footnotetext{
${ }^{370}$ A O Adede "Settlement of Disputes Arising under the Law of the Sea Convention" (1975) 69 AJIL 798, 798. [Settlement of Disputes under the Law of the Sea].

371 The LOSC has been described as the 'constitution for the oceans' by Tommy B Koh, reproduced in United Nations Law of the Sea: Official Text of the UNCLOS (St Martin's Press, London, 1983) xxxiii.

${ }^{372}$ Cesare P R Romano "The Settlement of Disputes under the 1982 Law of the Sea Convention: How Entangled Can We Get?" (2004) 103 (1) J Intl L \& Diplo 84, 87 [“The Settlement of Disputes under LOSC - How Entangled Can We Get?']. For various perspectives on the dispute settlement provisions of the Convention, see W Riphagen "Dispute Settlement in the 1982 United Nations Convention on the Law of the Sea" in Christos L Rozakis and Constantine A Stephanou The New Law of the Sea (North-Holland Publishing Company, Amsterdam, 1983) 281; Günther Jaenicke "Dispute Settlement under the Convention on the Law of the Sea" (1983) 43 (4) ZaöRV 813; Elliot L Richardson "Dispute Settlement under the Convention on the Law of the Sea: A Flexible and Comprehensive Extension of the Rule of the Law to Ocean Space" in Thomas Buergenthal (ed) Contemporary Issues in International Law - Essays in Honor of Louis B Sohn (N P Engel, Kehl, 1984) 149; Yogesh K Tyagi "The System of Settlement of Disputes Under the Law of the Sea Convention: An Overview" 25 (2) Indian J Intl L 191; Gerhard Erasmus "Dispute Settlement in the Law of the Sea" (1986) Acta Juridica 15; Mahdi El-Baghdadi "The Binding Nature of the Disputes Settlement Procedure in the Third U.N. Convention on the Law of the Sea: The International Seabed Authority" (1990/1991) 6 J Min L \& Poly 173; Thomas A Clingan Jr "Dispute Settlement" in The Law of the Sea: Ocean Law and Policy (Austin \& Winfield Publishers, Lanham (Maryland), 1994) 517; John E Noyes "The Third-Party Dispute Settlement Provisions of the 1982 United Nations Convention on the Law of the Sea: Implications for States Parties and for Nonparties" in M H Nordquist and J N Moore (eds) Entry into Force of the Law of the Sea Convention (Martinus Nijhoff Publishers, The Hague, 1995) 213; Robin Rolf Churchill and Alan Vaughan Lowe The Law of the Sea (Manchester University Press, New York, 1999) 447; Jon M Van Dyke "Louis B Sohn and the Settlement of Ocean Disputes" (2000) 33 Geo Wash Intl L Rev 31.
} 
therefore strictly speaking travaux préparatoires of the LOSC do not exist. ${ }^{373}$ However, some of the delegates who participated in UNCLOS III have traced the major developments in the negotiations, and drafts of the dispute settlement provisions in academic writing. ${ }^{374}$

This part is divided into 2 sections. Section A argues in support of the merits of including dispute settlement provisions in the LOSC, and section B gives a brief account of the core dispute settlement provisions.

\section{A The Importance of Incorporating Dispute Settlement Provisions into the Convention}

The compulsory dispute settlement provisions under the Convention have been called "a central component of the package deal" 375 that emerged from UNCLOS III. It is argued that the position of the dispute settlement provisions of the LOSC has been strengthened by their incorporation into the LOSC itself as opposed to an attachment as an optional protocol. Such a decision that made it a

\footnotetext{
373 "Prolegomena to the Disputes Settlement Part", above n 155, 253.

${ }^{374}$ See Shabtai Rosenne and Louis B Sohn (eds) United Nations Convention on the Law of the Sea 1982: A Commentary (vol 5, Martinus Nijhoff Publishers, Dordrecht, 1989) [Virginia Commentary]; William T Burke, Richard Legatski, William W Woodhead National and International Law Enforcement in the Ocean (University of Washington Press, Seattle, 1975) 134 - 136; P D Oelofsen "Some Comments on the Proposed Procedures for Dispute Settlement under a New Law of the Sea Convention" (1976) 2 SAYIL 192; Jonathan A Walz and Douglas Campbell III in David L Larson (ed) Major Issues of the Law of the Sea (University of New Hampshire, (Durham) New Hampshire, 1976) 175; John King Gamble Jr "The Law of the Sea Conference: Dispute Settlement in Perspective" (1976) 9 Vand J Transnatl L 323; A O Adede "Law of the Sea: The Scope of the Third-Party, Compulsory Procedures for Settlement of Disputes" (1977) 71 AJIL 305; Shabtai Rosenne "The Settlement of Disputes in the New Law of the Sea" (1978) 11-12 Revue Iranienne Des Relations Internationales 401; J Peter A Bernhardt "Compulsory Dispute Settlement in the Law of the Sea Negotiations: A Reassessment" (1978) 19 Va J Intl L 69; A O Adede "Law of the Sea - The Integration of the System of Settlement of Disputes under the Draft Convention as a Whole" (1978) 72 AJIL 84; Shabtai Rosenne "Settlement of Fisheries Disputes in the Exclusive Economic Zone" (1979) 73 AJIL 89; A O Adede "Toward the Formulation of the Rule of Delimitation of Sea Boundaries Between States with Adjacent or Opposite Coasts" (1979) 19 (2) Va J Intl L 207; Wm H Haubert II "Toward Peaceful Settlement of Ocean Space Disputes: A Working Paper" (1974) 11 San Diego L Rev 733; A O Adede "Streamlining the System for Settlement of Disputes under the Law of the Sea Convention" (1980) 1 Pace L Rev 15; George Pierce "Dispute Settlement Mechanisms in the Draft Convention on the Law of the Sea" (1981) 10 Denv J Intl L \& Poly 331.

${ }^{375}$ Ivan Shearer "Oceans Management Challenges for the Law of the Sea in the First Decade of the 21 st Century" in Alex G Oude Elferink and Donald R Rothwell (eds) Oceans Management in the 21st Century: Institutional Frameworks and Responses (Martinus Nijhoff Publishers, Leiden, 2004) $1,14$.
} 
part and parcel of the whole LOSC has been called a "major development", ${ }^{376}$ a "unique aspect" 377 and "a big step forward in the development of international law." ${ }^{378}$ Few authors have however explored this issue in depth. It is arguable that its effect would not have had as much merit had they been annexed to the LOSC as an optional protocol. ${ }^{379}$ During UNCLOS III, some states had decried the establishment of a regime for binding third party dispute settlement. ${ }^{380}$ The alternative option suggested by this group was to have dispute settlement provisions not as a part of the LOSC but to have the same annexed to it like an optional protocol. ${ }^{381}$ Nonetheless, the majority felt that not having the dispute settlement provisions as an integral part of the LOSC could weaken it and jeopardise its ratification and acceptance worldwide. ${ }^{382}$

This decision arguably owes its making to the failure of the dispute settlement provisions of the 1958 Geneva Conventions on the law of the sea. The 1958 Geneva Conventions provided for dispute settlement provisions in an optional protocol rather than as a part within the substantive body of laws. ${ }^{383}$ The 1958 Geneva Conventions brought about the law of the sea of that time in the form of four treaties. ${ }^{384}$ The Convention on Fishing and the Conservation of the Living Resources of the High Seas (Fishing Convention) had its own inbuilt dispute settlement provisions. ${ }^{385}$ But the Optional Protocol of Signature concerning the Compulsory Settlement of Disputes (Optional Protocol) was to

\footnotetext{
${ }^{376}$ A O Adede "The Basic Structure of the Disputes Settlement Part of the Law of the Sea Convention" (1982) $11(1 / 2)$ ODIL 125, 127.

377 John Warren Kindt "Dispute Settlement in International Environmental Issues: The Model provided by the 1982 Convention on the Law of the Sea" (1989) 22 Vand J Transnatl L 1097, 1099.

${ }^{378}$ Ocean Governance and the United Nations, above n 20, 32. See also Elisabeth Mann Borgese "The Process of Creating an Ocean Regime to Protect the Ocean's Resources" in Jon M Van Dyke, Durwood Zaelke and Grant Hewison (eds) Freedom for the Seas in the 21st Century: Ocean Governance and Environmental Harmony (Island Press, Washington DC, 1993) 23.

${ }^{379}$ See Louis B Sohn "Peaceful Settlement of Disputes in Ocean Conflicts: Does UNCLOS III Point the Way?" (1983) 46 Law \& Contemp Probs 195, 195.

${ }^{380}$ Virginia Commentary, above n 374, 43.

${ }^{381}$ See Virginia Commentary, above n 374, 43.

${ }^{382}$ Louis B Sohn "Settlement of Disputes Arising Out of the Law of the Sea Convention" (1975) 12 San Diego L Rev 495, 516.

${ }^{383}$ See Optional Protocol of Signature Concerning the Compulsory Settlement of Disputes (29 April 1958) 450 UNTS 169 [Optional Protocol].

${ }^{384}$ The four Treaties were: Convention on the Territorial Sea and the Contiguous Zone (29 April 1958) 516 UNTS 205; Convention on the High Seas (29 April 1958) 440 UNTS 11; Convention on Fishing and Conservation of the Living Resources of the High Seas (29 April 1958) 559 UNTS 285 [Fishing Convention]; Convention on the Continental Shelf (29 April 1958) 499 UNTS 311. For a commentary, see Arthur H Dean "The Geneva Conference on the Law of the Sea: What Was Accomplished" (1958) 52 AJIL 607.

${ }^{385}$ Fishing Convention, above n 384, art 9.
} 
govern dispute settlement under the other three Conventions. ${ }^{386}$ It is noteworthy that to date no dispute has been referred under the Optional Protocol or the Fishing Convention. ${ }^{387}$

Out of a total of 44 states that had originally signed the Optional Protocol, only 37 states actually followed it up with ratifications, definitive signatures or successions. ${ }^{388}$ Countries such as the United States, Canada and China, which had initially signed the Optional Protocol, refrained from finally ratifying and accepting it. ${ }^{389}$ Moreover, out of an average number of 52 states $^{390}$ that became parties to the other four conventions, the Optional Protocol had only 37 parties. Industrialised countries like Japan and Russia, which had actively participated in the other 1958 Geneva Conventions, chose not to get involved with the Optional Protocol at all. ${ }^{391}$ Taking all this into account, it would be fair to say that the dispute settlement provisions as an optional protocol of signature to the law of the sea had failed. Therefore, the delegates at UNCLOS III decided to keep the dispute settlement provisions integrated within the LOSC itself.

The dispute settlement provisions of the Convention may not be perfect, but are arguably the best that could be attained, given the many political forces that governed UNCLOS III. ${ }^{392}$ These provisions are available so as to protect the respective rights of parties, and to provide an expeditious and effective settlement in case a dispute is referred to them.

\footnotetext{
386 Optional Protocol, above n 383, art II.

387 Alan E Boyle "UNCLOS, the Marine Environment and the Settlement of Disputes" in Hendrik Ringbom (ed) Competing Norms in the Law of Marine Environmental Protection Focus on Ship Safety and Pollution Prevention (Kluwer Law International, London, 1997) 241, 244 (footnote 10).

388 The Optional Protocol received 14 Signatures, and seven states that had placed their Signatures, failed to Ratify, Definitively Sign or Succeed to it. See Multilateral Treaties Deposited with the Secretary-General, <http://untreaty.un.org/> (last accessed 2 December 2004). ${ }^{389}$ See Multilateral Treaties Deposited with the Secretary-General, above n 388.

390 The Convention on the Territorial Sea and the Contiguous Zone had 51 states parties; the Convention on the High Seas had 62 states parties; the Convention on Fishing and Conservation of the Living Resources of the High Seas had 37 states parties and the Convention on the Continental Shelf had 57 states parties. See Multilateral Treaties Deposited with the SecretaryGeneral, above n 388 .

391 The Russian Federation ratified the Convention on the Territorial Sea and the Contiguous Zone, the Convention on the High Seas and the Convention on the Continental Shelf. Japan had formally acceded to the Convention on the Territorial Sea and the Contiguous Zone and the Convention on the High Seas. See Multilateral Treaties Deposited with the Secretary-General, above n 388 .

${ }^{392}$ Shirley V Scott "The Contribution of the LOS Convention Organizations to its Harmonious Implementation" in Alex G Oude Elferink and Donald R Rothwell (eds) Oceans Management in the 21st Century: Institutional Frameworks and Responses (Martinus Nijhoff Publishers, Leiden, 2004) 313.
} 
The core dispute settlement provisions in the LOSC are laid down in Part $\mathrm{XV}$, and are divided into three Sections - (i) General Provisions, (ii) Compulsory Procedures Entailing Binding Decisions, and (iii) Limitations and Exceptions to Applicability to Section 2. The dispute settlement provisions of the LOSC are also found in its Annexes V - VIII, and other dispute settlement provisions remain scattered in the LOSC and its Annexes of which Section 5 of Part XI, dealing with dispute settlement with respect to activities in the Area, ${ }^{393}$ deserve mention. ${ }^{394}$ However, the present part is confined to looking at Part XV alone, primarily because it comprises the "backbone" 395 of the Convention's dispute settlement machinery, and more generally on account of constraints of space within the scope of this thesis.

\section{$1 \quad$ General provisions}

Two basic principles of dispute settlement can be identified from the provision in Section 1. First, states parties are obliged to settle disputes by peaceful means. This obligation becomes clear from an analysis of Articles 279, 283 and 285. Secondly, states parties have been granted high degree of flexibility in choosing the means to settle their disputes. This theme can be identified from an analysis of Articles 280, 281, 282 and 284.

Article 279 stipulates that the basic obligation of states parties is to settle all disputes that concern the interpretation or application of the LOSC by peaceful means. ${ }^{396}$ Article 283 obliges states parties to a dispute to initiate and maintain an effective system for exchange of views and talks with regard to the settlement of disputes. ${ }^{397}$ Article 285 provides that entities other than states are

\footnotetext{
${ }^{393}$ For a discussion, see Louis B Sohn "Settlement of International Disputes Relating to Deep Sea-Bed Mining" in Festschrift für Rudolf Bindschedler Zum 65 Geburtstag am 8 Juli 1980 (Stämpfli \& Cie, Bern, 1980) 443, 446.

394 "Possible Role of the International Tribunal for the Law of the Sea in Interpretation and Progressive Development of the Law of the Sea", above n 23, 95.

395 "Possible Role of the International Tribunal for the Law of the Sea in Interpretation and Progressive Development of the Law of the Sea", above n 23, 95.

${ }^{396}$ LOSC, art 279.

${ }^{397}$ LOSC, art 283.
} 
free to have recourse to the provisions under this Section to peacefully settle their disputes arising pursuant to Section 5 of Part XI. ${ }^{398}$

Under the second theme of flexibility as identified in Section 1, states parties are free to choose the mode they may adopt in settling a dispute as long as the means are peaceful. Article 280 stipulates that states parties may at any time mutually agree to refrain from using the dispute settlement provisions of the LOSC and settle a dispute between them by any peaceful means of their choice. ${ }^{399}$ Under Article 281, if the parties agree to settle a dispute by any peaceful means of their choosing, the procedures under Part XV can only be invoked if no settlement is reached, and the agreement between them excludes no further procedure. ${ }^{400}$ Further, if the parties have agreed on a time limit, Part XV procedures can be utilised only on the expiry of the time limit. ${ }^{401}$

Article 282 provides for a situation where disputant states parties are also signatories to an agreement of a general, regional or bilateral nature. ${ }^{402}$ If under such agreement they have bound themselves to use a dispute settlement procedure that would entail a binding decision, such a procedure would have precedence over those in Part XV of the LOSC. ${ }^{403}$ As will be seen later in this chapter, it is this provision that proved to be a hurdle for the jurisdiction of an Annex VII arbitral tribunal in the Southern Bluefin Tuna Case - Australia and New Zealand v Japan. ${ }^{404}$

Article 284 provides that any party to the dispute may invite the other to submit the dispute to conciliation. ${ }^{405}$ However, if the other party rejects the invitation or abstains from accepting it by its inaction, the process fails. ${ }^{406}$ In a case where the invitation is accepted, it is again left to the parties to choose the procedure to be adopted for the conciliation either under Annex V, section 1, or another conciliation procedure. ${ }^{407}$ Again, if the parties are unable to reach an agreement with regard to the procedure, the process is terminated midway and

\footnotetext{
${ }^{398}$ LOSC, art 285.

${ }^{399}$ LOSC, art 280.

${ }^{400}$ LOSC, art 281(1).

${ }^{401}$ LOSC, art 281(2).

${ }^{402}$ LOSC, art 282.

${ }^{403}$ LOSC, art 282.

${ }^{404}$ See part III D of the present chapter.

${ }^{405}$ LOSC, art 284(1).

${ }^{406}$ LOSC, art 284(3).

${ }^{407}$ LOSC, art 284(1) and (2).
} 
parties are free to initiate the compulsory procedures entailing binding decisions under Part XV, Section 2 of the LOSC, after an exchange of views. ${ }^{408}$

\section{Compulsory procedures}

Section 2 contains provisions for compulsory procedures for dispute settlement leading to binding decisions.

Article 286 provides that, subject to the provisions laid down under Section 3, compulsory procedures under Section 2 can be initiated only where no settlement has been achieved by recourse to Section 1 procedures. ${ }^{409}$ Article 287 lays down the choice of procedure, which is available to disputant parties for settling their disputes. ${ }^{410}$ At the time of signing, ratifying or acceding to the LOSC, or any time thereafter, states have the option of choosing by means of a declaration, one or more of the forums available for settling their disputes. ${ }^{411}$ Scholars have viewed such choice of procedures differently, and their opinions range from positive support for the "smorgasbord approach" criticism for the "cafeteria' approach.", ITLOS, (ii) ICJ, (iii) an arbitral tribunal, ${ }^{414}$ and (iv) a special arbitral tribunal. ${ }^{415}$ The residual jurisdiction is vested on the arbitration procedures under Annex VII in cases where a state party is not covered by a declaration in force with regard to its choice of procedure, ${ }^{416}$ and where both parties have not selected the same procedure. $^{417}$

Article 288 gives jurisdiction to the forums under Article 287 over all disputes relating to the interpretation or application of the LOSC submitted to

\footnotetext{
${ }^{408}$ LOSC, arts 283(2) and 284(3).

${ }^{409}$ LOSC, art 286.

${ }^{410}$ LOSC, art 287(1).

${ }^{411}$ LOSC, art 287(1).

412 Jonathan I Charney "The Implications of Expanding International Dispute Settlement Systems: The 1982 Convention on the Law of the Sea" (1996) 90 AJIL 69, 71.

413 Alan E Boyle "Dispute Settlement and the Law of the Sea Convention: Problems of Fragmentation and Jurisdiction" (1997) 46 ICLQ 37, 40.

${ }^{414}$ LOSC, Annex VII.

${ }^{415}$ LOSC, Annex VIII and art 287(1) See generally Budislav Vukas "Main Features of Courts and Tribunals Dealing with Law of the Sea Cases" in M H Nordquist and J N Moore (eds) Current Marine Environmental Issues and the International Tribunal for the Law of the Sea (Kluwer Law International, The Hague, 2001) 217.

${ }^{416}$ LOSC, art 287(3).

${ }^{417}$ LOSC, art 287(5).
} 
them under Part XV. ${ }^{418}$ The jurisdiction of any court or tribunal also extends to any dispute emanating from any international agreement related to the purposes of the LOSC. ${ }^{419}$ SDC of ITLOS or any other arbitral tribunal referred to in Part XI Section 5 of the LOSC would have jurisdiction over disputes in accordance with the procedure specified therein. ${ }^{420}$ Should there be any challenge as to the jurisdiction of a court or tribunal, it is completely within the competence of the forum in question to decide conclusively on the validity of such jurisdiction. ${ }^{421}$

Article 289 lays down that a court or tribunal having jurisdiction in a dispute involving scientific or technical issues may at the request of a party or on its own accord choose at least two scientific or technical experts to guide it. ${ }^{422}$ Experts should preferably be chosen from a list prepared in accordance with Article 2 of Annex VIII, and would not have the right to vote in the adjudicative process. $^{423}$

Under Article 290, a court or a tribunal to which a dispute has been submitted may prescribe appropriate provisional measures pending its final decision. ${ }^{424}$ The provisional measures may be revoked or modified when the conditions that led to their prescription no longer subsist. ${ }^{425}$ The provisional measures may be prescribed, modified or revoked only at the request of a party to the dispute, and after the parties to the dispute have been given an opportunity of being heard. ${ }^{426}$ The other provisions on provisional measures, and the jurisprudence under it so far shall be discussed in part III of this chapter.

Article 292 provides that a petition for the prompt release of a vessel or its crew may be brought before any court or tribunal mentioned in Article 287 (1). ${ }^{427}$ Such petition could be brought on the ground that the authorities of the detaining state have acted in contravention of the provisions of the LOSC in not

\footnotetext{
${ }^{418}$ LOSC, 288(1).

${ }^{419}$ LOSC, art 288(2).

${ }^{420}$ LOSC, art 288(3).

${ }^{421}$ LOSC, art 288(4).

${ }^{422}$ LOSC, art 289.

${ }^{423}$ LOSC, art 289.

${ }^{424}$ LOSC, art 290(1).

${ }^{425}$ LOSC, art 290(2).

${ }^{426}$ LOSC, art 290(3).

${ }^{427}$ LOSC, art 292(1).
} 
releasing the vessel or its crew upon posting of a reasonable bond ${ }^{428}$ or other financial security. ${ }^{429}$ In case the parties fail to agree upon a forum within 10 days from the time of detention, the question may be posed before the forum chosen by the detaining state under Article 287 or finally to ITLOS. ${ }^{430}$ Such an application for prompt release may also be made by or on behalf of the flag state of the vessel. ${ }^{431}$ The court or tribunal is only required to deal with the question of release without going into the merits of any case that might be pending before a domestic forum of the detaining state involving the same issue. ${ }^{432}$ A further discussion on the provisions of Article 292 and the disputes that have been invoked under it follows in part II of this chapter.

Article 293 provides that the provisions of the LOSC as well as other rules of international law not incompatible with the provisions of the LOSC would need to be applied by a court or tribunal under Part XV ${ }^{433}$ A court or a tribunal is also empowered to decide a case in accordance with what is just and good, provided the parties to the dispute agree. ${ }^{434}$

Article 294 provides that a court or a tribunal to which a dispute under Article 297 is submitted shall examine whether the claim represents an abuse of the legal process or whether it is prima facie well founded. ${ }^{435}$ On receipt of the application, it is the duty of the court or tribunal to notify the other party or parties to the application so received, and designate a reasonable time limit within which the parties to the dispute may request it to make a determination on the nature of the case. ${ }^{436}$ Parties to the dispute have been guaranteed their right to make preliminary objections in accordance with the applicable rules of procedure. $^{437}$

\footnotetext{
${ }^{428}$ For a discussion, see D J Devine "Relevant Factors in Establishing a Reasonable Bond for Prompt Release of a Vessel under Article 292 (1) of the United Nations Convention on the Law of the Sea 1982" (2002) 27 SAYIL 140.

${ }^{429}$ LOSC, art 292(1).

${ }^{430}$ LOSC, art 292(1).

${ }^{431}$ LOSC, art 292(2).

${ }^{432}$ LOSC, art 292(3).

${ }^{433}$ LOSC, art 293(1).

${ }^{434}$ LOSC, art 293(2).

${ }^{435}$ LOSC, art 294(1). For a discussion, see Tullio Treves "Preliminary Proceedings in the Settlement of Disputes under the United Nations Law of the Sea Convention: Some Observations" in Nisuke Endo and others (eds) Liber Amicorum Judge Shigeru Oda (vol 1, Kluwer Law International, The Hague, 2002) 749, 753.

${ }^{436}$ LOSC, art 294(2).

${ }^{437}$ LOSC, art 294(3).
} 
Article 295 provides that local remedies must be exhausted where required by international law, for disputes submitted under Part XV. ${ }^{438}$ Finally, Article 296 stipulates that the decision of a court or tribunal having jurisdiction over disputes covered under Section 2 of Part XV are final, and must be complied with by all the parties to the dispute. ${ }^{439}$ Further, any such decision would only extend to and bind the parties to the case, and only with respect to that particular dispute in which it has been rendered. ${ }^{440}$

\section{$3 \quad$ Limitations and exceptions}

Section 3 of Part XV contains provisions that limit the applicability of and provide exceptions to the operation of compulsory dispute settlement procedures.

Article 297 lays down some automatic limitations to the procedures under Section 2, and refers to disputes involving three specific areas - (i) coastal state sovereignty and jurisdiction, ${ }^{441}$ (ii) marine scientific research, ${ }^{442}$ and (iii) fisheries. $^{443}$ The provisions dealing with disputes about marine scientific research and fisheries have a similar approach, and most of such disputes continue to be covered within the scope of Section 2 leaving only a few specific disputes to be excluded. ${ }^{444}$ These provisions have been called "relatively straightforward" 445 since they begin with a statement of the general rule that such disputes would be settled according to the provisions of Section 2, followed by a mention of the right of a coastal state to exclude certain specific disputes from compulsory dispute settlement procedures. ${ }^{446}$

However, it seems that most of disputes involving coastal state sovereign rights and jurisdiction have been removed from the reach of the compulsory procedures for settling disputes. Only a few kinds of disputes would be subjected

\footnotetext{
${ }^{438}$ LOSC, art 295.

${ }^{439}$ LOSC, art 296(1).

${ }^{440}$ LOSC, art 296(2).

${ }^{441}$ LOSC, art 297(1).

${ }^{442}$ LOSC, art 297(2).

${ }^{443}$ LOSC, art 297(3).

${ }^{444}$ LOSC, art 297(2) and (3).

${ }^{445}$ E D Brown "Dispute Settlement and the Law of the Sea: the UN Convention Regime" (1997)

21 (1) Marine Policy 17, 21 ["Dispute Settlement and the Law of the Sea: The UN Convention Regime"].

446 "Dispute Settlement and the Law of the Sea: The UN Convention Regime", above n 445, 21.
} 
to the procedures under Section $2 .{ }^{447}$ Such disputes are those relating to acts of coastal states in contravention of the freedoms of navigation, over flight, laying of submarine cables and pipelines, and any of the other internationally lawful uses of the sea as provided under Article $58 .{ }^{448}$ Similarly, in cases of contravention of the above-mentioned freedoms by a state exercising them, Section 2 procedures would be attracted. ${ }^{449}$ Cases involving an allegation that a coastal state has contravened certain international rules and standards involving the protection and preservation of the marine environment are also subject to compulsory dispute settlement procedures. ${ }^{450}$

Coastal states are not obliged to accept submission to compulsory dispute settlement procedures in all matters relating to marine scientific research. ${ }^{451}$ Two classes of disputes are specifically excluded - (i) in the exercise of its rights or discretion under Article 246, ${ }^{452}$ and (ii) its decision to order cessation of marine scientific research in accordance with Article 253. ${ }^{453}$ However, disputes relating to the above-mentioned classes shall be submitted to conciliation under Annex V, Section 2, although the conciliation commission shall not call in question the rights of the coastal state under Article 246(5) and (6). ${ }^{454}$

Similarly, fisheries related disputes are subject to compulsory dispute settlement procedures except in the following cases - exercise of coastal states sovereign rights in the EEZ, coastal state discretion in determining the allowable catch, its harvesting capacity, the allocation of surpluses to other states and the terms and conditions established in its conservation and management laws and regulations. ${ }^{455}$ These disputes can be submitted to conciliation under Annex V, Section 2 in three situations - (i) the failure of a coastal state to comply with its obligations of conservation and maintenance of living resources in the EEZ, ${ }^{456}$ (ii) the arbitrary refusal of a coastal state to determine the allowable catch, and its capacity to harvest living marine resources that another state is interested in

\footnotetext{
${ }^{447}$ LOSC, art 297(1).

${ }^{448}$ LOSC, art 297(1)(a).

${ }^{449}$ LOSC, art 297(1)(b).

${ }^{450}$ LOSC, art 297(1)(c).

${ }^{451}$ LOSC, art 297(2).

${ }^{452}$ LOSC, art 297(2)(a)(i).

${ }^{453}$ LOSC, art 297(2)(a) (ii).

${ }^{454}$ LOSC, art 297(2)(b).

${ }^{455}$ LOSC, art 297(3)(a).

${ }^{456}$ LOSC, art 297(3)(b)(i).
} 
exploiting, ${ }^{457}$ and (iii) the arbitrary refusal of a coastal state to allocate declared surpluses under Articles 62, 69 and 70, and terms and conditions established by it. $^{458}$

Under Article 298, states have the option of excluding by a declaration in writing any of the compulsory dispute settlement procedures with respect to certain specified disputes. These are - (i) disputes relating to sea boundaries, historic bays or titles ${ }^{459}$ (ii) disputes concerning military activities and law enforcement activities concerning marine scientific research or fisheries in the EEZ, ${ }^{460}$ and (iii) disputes in respect of which the Security Council of the UN is exercising functions assigned to it by the Charter of the UN. ${ }^{461}$

However, a state that has excluded disputes relating to sea boundaries, historic bays or titles from Section 2 procedures would have to accept submission to conciliation under Annex V, Section 2 at the request of any party to the dispute. $^{462}$ Such submission to conciliation would be necessary only where such dispute arises after the entry into force of the LOSC, and no agreement has been reached between the parties within a reasonable period of time with regard to the dispute. ${ }^{463}$ Further, any case that involves the concurrent consideration of any unsettled dispute involving sovereignty, and other rights over insular or land territory is excluded from submission to conciliation. ${ }^{464}$ After the conciliation commission presents its report that states the reasons on which it is based, parties are required to negotiate an agreement on the basis of such report. ${ }^{465}$ If these negotiations do not result in an agreement, the parties may mutually decide to submit the issue to a procedure under Section 2, unless they otherwise agree. ${ }^{466}$

Article 299 provides that a dispute that is automatically excluded under Article 297, or has been excluded by declaration under Article 298, may nevertheless be submitted to compulsory dispute settlement by agreement of the

\footnotetext{
${ }^{457}$ LOSC, art 297(3)(b)(ii).

${ }^{458}$ LOSC, art 297(3)(b)(iii).

${ }^{459}$ LOSC, art 298(1)(a).

${ }^{460}$ LOSC, art 298(1)(b).

${ }^{461}$ LOSC, art 298(1)(c). For a drafting history of the military activities exception, see Mark W Janis "Dispute Settlement in the Law of the Sea Convention: The Military Activities Exception" (1977) 4 (1) ODIL 51.

${ }^{462}$ LOSC, art 298(1)(a)(i).

${ }^{463}$ LOSC, art 298 (1)(a)(i).

${ }^{464}$ LOSC, art 298 (1)(a)(i).

${ }^{465}$ LOSC, art 298 (1)(a)(ii).

${ }^{466}$ LOSC, art 298 (1)(a)(ii).
} 
parties to the dispute. ${ }^{467}$ Further, it reinforces the right of disputant states to settle the dispute amicably by any means of their choice. ${ }^{468}$

\section{PROMPT RELEASE CASES}

Article 292 of the LOSC, dealing with disputes regarding the prompt release of vessels and crews, was welcomed as a new and innovative provision in the international law of the sea. ${ }^{469}$ Its provisions and procedures are novel and the Article itself does not have any antecedents in treaties prior to the LOSC. ${ }^{470}$

The Convention gives broad sovereign powers to coastal states for exploring, exploiting, conserving and managing their EEZs ${ }^{471}$ as well as for the protection and preservation of the marine environment. ${ }^{472}$ Coastal states are authorised to enact laws with regard to their EEZs and control foreign access to the resources found there. ${ }^{473}$ For the protection of national interests, coastal states are empowered to board, inspect, arrest and institute judicial proceedings against vessels and crews to enforce their laws and regulations in the EEZ. ${ }^{474}$ Similarly, a coastal state may detain vessels or institute proceedings against them for violating applicable international rules and standards for combating pollution, which have been codified in its own laws. ${ }^{475}$ The common element under Articles 73 and 220 is that of enforcement in accordance with coastal state's domestic laws and regulations. ${ }^{476}$

\footnotetext{
${ }^{467}$ LOSC, art 299(1).

${ }^{468}$ LOSC, art 299(2).

${ }^{469}$ For a detailed discussion on the prompt release of vessels and crews before ITLOS, see AnneKatrin Escher "Release of Vessels and Crews before the International Tribunal for the Law of the Sea" Part 1 and 2 (2004) 3 (2) LPICT 205.

${ }^{470}$ David H Anderson "Investigation, Detention and Release of Foreign Vessels under the UN Convention on the Law of the Sea of 1982 and other International Agreements" (1996) 11 (2) IJMCL 165, 167. For in-depth analysis of the provisions on prompt release in the Convention and the Rules of the Tribunal, see Tullio Treves "The Proceedings Concerning Prompt Release of Vessels and Crews before the International Tribunal for the Law of the Sea" (1996) 11 (2) IJMCL 179; Rainer Lagoni "The Prompt Release of Vessels and Crews before the International Tribunal for the Law of the Sea: A Preparatory Report" (1996) 11 (2) IJMCL 147; Florian H Th Wegelein "The Rules of the Tribunal in the Light of Prompt Release" (1999) 30 ODIL 255.

${ }^{471}$ LOSC, Part V. See generally B Kwiatkowska The 200 Mile EEZ in the New Law of the Sea (Dordrecht, Martinus Nijhoff Publishers, 1989) and D Attard The Exclusive Economic Zone (Oxford University Press, Oxford, 1987).

${ }^{472}$ LOSC, Part XII.

${ }^{473}$ LOSC, arts 56, 57, 61 and 62.

${ }^{474}$ LOSC, art 73(1).

${ }^{475}$ LOSC, art 220(6).

${ }^{476}$ For discussions on coastal state enforcement in maritime zones, see Anne Bardin "Coastal State Jurisdiction over Foreign Vessels" (2002) 14 Pace Intl L Rev 27; Doris Konig "The
} 
This state prerogative can be subject to challenge by or on behalf of flag states $^{477}$ of detained vessels as to its reasonableness under Article 292. Article 292 is so designed that detained ships and their crews may be released without the infliction of "deleterious effects on the owner of the vessel and also on international commercial transactions." 478 Provisions on vessel release, such as those found under Article 292 are important as they accommodate economic, humanitarian, safety and environmental concerns. ${ }^{479}$ Since such international provisions provide interim relief and contemplate enforcement proceedings against the vessel and its crew in the courts of the detaining states, the purpose of the bond is to protect against failure to appear and pay the penalty imposed by the detaining state. ${ }^{480}$ Similarly, from the flag states' point of view, the bond serves to enable the vessel and its crew to return to their commercial profitmaking activities. ${ }^{481}$ Clearly, the aim of the provisions such as Articles 73 and 292 of the LOSC is to balance the diverse interests of coastal and flag states ${ }^{482}$ a balance that needs to be preserved in dispute settlement procedures. ${ }^{483}$

This section has been divided into four sub-sections dealing with various aspects of the prompt release jurisprudence that has developed to date. These areas have been chosen to highlight some of the key impacts of the prompt release jurisprudence on oceans governance. They are dealt with in the following

Enforcement of the International Law of the Sea by Coastal and Port States" (2002) 62 (1-2) ZaöRV 1; David Anderson "The Regulation of Fishing and Related Activities in Exclusive Economic Zones" in Erik Franckx and Philippe Gautier (eds) La Zone Économique Exclusive Et La Convention Des Nations Unies Sur Le Droit De La Mer, 1982-2000: Un Premier Bilan De La Pratique Des Etats = The Exclusive Economic Zone And The United Nations Convention On The Law Of The Sea, 1982-2000: A Preliminary Assessment Of State Practice (Bruylant, Brussels, 2003) 31; Martin Tsamenyi and Kwame Mfodwo "Enforcing Fisheries Jurisdiction in the EEZ: Some Legal and Policy Considerations" in Doug MacKinnon and Dick Sherwood (eds) Policing Australia's Offshore Zones: Problems and Prospects (Centre for Maritime Policy, University of Wollongong, Wollongong, 1997) 254.

${ }^{477}$ LOSC, art 279(2).

478 The "Juno Trader" Case, (Saint Vincent and the Grenadines v Guinea-Bissau) (Prompt Release) [2004] <http://www.itlos.org/> (last accessed 1 December 2005) para 4, Judge Rao's Separate Opinion.

${ }^{479}$ Bernard H Oxman "Observations on Vessel Release under the United Nations Convention on the Law of the Sea" (1996) 11 (2) IJMCL 201, 203 ["Observations on Vessel Release"].

480 "Observations on Vessel Release", above n 479, 205.

481 The "Camouco" Case, (Panama v France) (Prompt Release) [2000] <http://www.itlos.org/> (last accessed 1 December 2005) para 5 Judge Treves dissenting.

${ }_{482}$ The "Monte Confurco" Case (Seychelles V France) (Prompt Release) [2000] $<$ http://www.itlos.org/> (last accessed 1 December 2005) para 70, Judgment of the majority [The “Monte Confurco" Judgment].

483 Oscar Schachter "Concepts and Realities in the New Law of the Sea" in Giulio Pontecorvo (ed) The New Order of the Oceans: The Advent of a Managed Environment (Columbia University Press, New York, 1986) 29, 45. 
order - discounting of bonds, uncertainty among coastal states, proceeds of the catch in the reasonableness of bond, and Illegal Unreported and Unregulated (IUU) fishing ${ }^{484}$ and prompt release procedures.

\section{A “Discounting” of Bonds}

In line with the objective of balancing the interests of fishing states and coastal states, the LOSC gave ITLOS a key role to play in resolving disputes between these two groups over alleged illegal fishing. ${ }^{485}$ In the event a coastal state arrests a foreign vessel for the infraction of its laws, domestic proceedings lead to the determination of a bond to allow the release of the vessel and crew. Only when the coastal state refuses to release the vessel and crew on the posting of a reasonable bond, or asks for a bond that the flag state considers unreasonable, that prompt release proceedings can be triggered under the Convention. ${ }^{486}$ Under the unique compulsory jurisdiction that ITLOS enjoys with regard to prompt release cases, an emerging issue of "discounting" of bonds is noteworthy.

In all but one of the prompt release cases disputed before ITLOS, the detaining states had asserted their claim over certain security or bond as preconditions for the release of arrested vessels and crews. ${ }^{487}$ In turn, the flag states involved had maintained that the amount or form of the bond sought was unreasonable. ITLOS has been noted for its practice of overturning as "unreasonable", the decisions of coastal states regarding conditions for release of

\footnotetext{
${ }^{484}$ For an explanation on the origins of the term IUU fishing, see William Edeson "The International Plan of Action on Illegal Unreported and Unregulated Fishing: The Legal Context of a Non-Legally Binding Instrument" (2001) 16 (4) IJMCL 603, 605. For a discussion on the present nature of IUU fishing, see Marcus Haward "IUU Fishing: Contemporary Practice" in Alex G Oude Elferink and Donald R Rothwell (eds) Oceans Management in the 21st Century: Institutional Frameworks and Responses (Martinus Nijhoff Publishers, Leiden, 2004) 87.

${ }^{485}$ Donald R Rothwell and Tim Stephens "Illegal Southern Ocean Fishing and Prompt Release: Balancing Coastal and Flag State Rights and Interests" (2004) 53 ICLQ 171, 171 - 172 ["Illegal Southern Ocean Fishing and Prompt Release"]. See generally Rüdiger Wolfrum "The Role of the International Tribunal for the Law of the Sea" in Myron H Nordquist and John Norton Moore (eds) Current Fisheries Issues and the Food and Agriculture Organization of the United Nations (Martinus Nijhoff Publishers, The Hague, 2000) 369 - 385.

${ }^{486}$ LOSC, art 292(1).

${ }^{487}$ There was no bond or other financial security requested by Guinea and none offered either by Saint Vincent and the Grenadines in the " $M / V$ Saiga" Case. The "M/V Saiga" Case (Saint Vincent and the Grenadines v Guinea) (Prompt Release) [1997]<http://www.itlos.org/> (last accessed 1 December 2005) para 31 Judgment of the majority [The $M / V$ "Saiga” Judgment].
} 
vessels and crews. ${ }^{488}$ It can be argued that such practice of "discounting" bonds is disturbing the balance of interests between coastal states and flag states that the negotiators at UNCLOS III strove hard to achieve. The Tribunal has been accused of giving insufficient consideration to the basic conservationist objectives as laid down in the Convention, by narrowly interpreting key enforcement and dispute settlement provisions contained in it. ${ }^{489}$ It can also be seen that some of the obvious consequences resulting from this practice have the potential to defeat the cause of good oceans governance. It can also be argued that the Tribunal's inability to lay down clear and consistent criteria for the determination of a reasonable bond increases uncertainty and the chances of conflict. None of the above consequences augur well for good oceans governance.

Of all prompt release applications heard so far, five directly involved fishing ${ }^{490}$ and one related to bunkering ${ }^{491}$ as an activity "ancillary to fishing". 492 Here, it warrants recall that prompt release applications under Article 292 seek relief in the nature of interim or interlocutory orders. The court or tribunal faced with such an application is required to deal only with the question of release without prejudice to the merits of any case before the domestic forums of the coastal state. ${ }^{493}$ Nonetheless, for the sake of properly ascertaining the reasonableness of a bond or financial security, a court or tribunal could examine the facts and circumstances of the case, since "[r]easonableness cannot be determined in isolation from facts". ${ }^{494}$ Therefore, given the basic facts and without going into the intricacies of individual cases, it is worthwhile to engage in a comparative study of bonds that detaining states have sought and which have been turned down as "unreasonable" by ITLOS. It is also interesting to see what bond amounts ITLOS prescribed as reasonable, and comparing that figure with

\footnotetext{
${ }^{488}$ Andrew Serdy and Michael Bliss "Prompt Release of Fishing Vessels: State Practice in the Light of the Cases before the International Tribunal for the Law of the Sea" in Alex G Oude Elferink and Donald R Rothwell (eds) Ocean Management in the $21^{\text {st }}$ Century: Institutional Frameworks and Responses (Martinus Nijhoff Publishers, Leiden, 2004) 273, 273.

489 Adrienne J Oppenheim "The Plight of the Patagonian Toothfish: Lessons from the Volga Case” (2004) 30 Brook J Int'l L 293, 295.

${ }^{490}$ Camouco, Monte Confurco, Grand Prince, Volga and Juno Trader

491 The $M / V$ "Saiga" was alleged to have been serving as bunkering vessel illegally supplying fuel and oil to fishing vessels and other vessels off the coast of Guinea at the time of its arrest. The $M / V$ "Saiga” Judgment, above n 487, para 28.

${ }^{492}$ The $M / V$ "Saiga” Judgment, above 487, para 64.

${ }^{493}$ LOSC, art 292(3).

${ }^{494}$ The “Monte Confurco" Judgment, above n 482, para 74.
} 
what the detaining state had sought in the first place. Such a comparison may be found tabulated under TABLE - I. 
TABLE - I PROMPT RELEASE CASES AT ITLOS AND BONDS PRESCRIBED

\begin{tabular}{|c|c|c|c|c|c|c|c|c|c|c|c|}
\hline $\begin{array}{l}\text { S1. } \\
\text { No. }\end{array}$ & $\begin{array}{c}\text { Name of } \\
\text { Case }\end{array}$ & Applicant & Respondent & $\begin{array}{c}\text { Date } \\
\text { Arrested }\end{array}$ & $\begin{array}{c}\text { Date of } \\
\text { Application }\end{array}$ & $\begin{array}{c}\text { Date of } \\
\text { Judgment }\end{array}$ & $\begin{array}{c}\text { Bond } \\
\text { sought by } \\
\text { Respondent } \\
\text { (A) }\end{array}$ & $\begin{array}{l}\text { Bond } \\
\text { offered by } \\
\text { Applicant }\end{array}$ & $\begin{array}{c}\text { Bond } \\
\text { prescribed } \\
\text { by ITLOS } \\
\text { (B) }\end{array}$ & $\begin{array}{l}\text { Reduction } \\
\text { in amount } \\
\text { of Bond } \\
\mathrm{A}-\mathrm{B}=\mathrm{C}\end{array}$ & $\begin{array}{c}\text { Percentage } \\
\text { of Bond } \\
\text { Reduction } \\
\mathrm{C} / \mathrm{A}=\mathrm{D} \%\end{array}$ \\
\hline 1. & $\begin{array}{l}\text { The } \\
\text { "M/V } \\
\text { Saiga" } \\
\text { Case }\end{array}$ & $\begin{array}{l}\text { Saint } \\
\text { Vincent } \\
\text { and the } \\
\text { Grenadines }\end{array}$ & Guinea & $28 / 10 / 1997$ & $13 / 11 / 1997$ & $04 / 12 / 1997$ & - & - & $\begin{array}{l}\text { US \$ } \\
400,000+ \\
\text { Gasoil } \\
\text { discharged }\end{array}$ & - & - \\
\hline 2. & $\begin{array}{l}\text { The } \\
\text { "Camouco" } \\
\text { Case }\end{array}$ & Panama & France & $28 / 09 / 1999$ & $17 / 01 / 2000$ & $07 / 02 / 2000$ & $\begin{array}{l}\text { FF } \\
20,000,000\end{array}$ & $\begin{array}{l}\text { FF } \\
950,000\end{array}$ & $\begin{array}{l}\text { FF } \\
8,000,000\end{array}$ & $\begin{array}{l}\text { FF } \\
12,000,000\end{array}$ & $60 \%$ \\
\hline 3. & $\begin{array}{l}\text { The } \\
\text { "Monte } \\
\text { Confurco" } \\
\text { Case }\end{array}$ & Seychelles & France & $08 / 11 / 2000$ & $27 / 11 / 2000$ & $18 / 12 / 2000$ & $\begin{array}{l}\text { FF } \\
56,400,000\end{array}$ & $\begin{array}{l}\mathrm{FF} \\
2,200,000\end{array}$ & $\begin{array}{l}\text { FF } \\
18,000,000\end{array}$ & $\begin{array}{l}\mathrm{FF} \\
38,400,000\end{array}$ & $68.09 \%$ \\
\hline 4. & $\begin{array}{l}\text { The } \\
\text { "Volga" } \\
\text { Case }\end{array}$ & Russia & Australia & $07 / 02 / 2002$ & $02 / 12 / 2002$ & $23 / 12 / 2002$ & $\begin{array}{l}\text { AU \$ } \\
3,332,500\end{array}$ & $\begin{array}{l}\text { AU \$ } \\
500,000\end{array}$ & $\begin{array}{l}\text { AU \$ } \\
1,920,000\end{array}$ & $\begin{array}{l}\text { AU \$ } \\
1,412,500\end{array}$ & $42.39 \%$ \\
\hline 5. & $\begin{array}{l}\text { The } \\
\text { "Juno } \\
\text { Trader" } \\
\text { Case }\end{array}$ & $\begin{array}{l}\text { Saint } \\
\text { Vincent } \\
\text { and the } \\
\text { Grenadines }\end{array}$ & $\begin{array}{l}\text { Guinea- } \\
\text { Bissau }\end{array}$ & $26 / 09 / 2004$ & $18 / 11 / 2004$ & $18 / 12 / 2004$ & $\begin{array}{l}\text { No less than } \\
€ 1,227,214\end{array}$ & $\begin{array}{c}- \\
€ 50,000^{*}\end{array}$ & $€ 308,770$ & $€ 918,444$ & $74.84 \%$ \\
\hline
\end{tabular}

* The Shipownwers Protection Agency, acting as the Protection and Indemnity Club of the owners of the Juno Trader had posted the amount with the Government of Guinea-Bissau in return for its release. 
ITLOS has, in all cases before it, deemed as unreasonable the bond amounts sought by the detaining states. ${ }^{495}$ In doing so, ITLOS has also reduced considerably the amount of bond that the arrested flag state vessels were initially required to deposit with the detaining state. Such "discounts" allowed by ITLOS on original bond amounts sought by coastal states have been as high as 74.84 per cent as witnessed in the "Juno Trader" Case. ${ }^{496}$ It had been said that the "Volga" Case marked a "caesura" in this trend and had restored the balance of coastal and flag state rights. ${ }^{497}$ However, the "Juno Trader" Case has allayed any confidence that the 'discounting' of bonds has become an issue of the past.

Having witnessed the varying degrees to which the Tribunal allowed a "discount" on the bond amounts in the prompt release cases before it, it is worthwhile to analyse the process in which it did so. The following paragraphs contain a discussion on the "discounting" of bonds by the Tribunal and the criteria it has relied upon in determining a reasonable bond as seen on a case to case basis. The argument here is that such practice of "discounting" bonds can have a detrimental impact on oceans governance.

As the first case appearing on the Tribunal's docket, the judgment in this case was deemed to be "controversial." ${ }^{498}$ There are many controversial aspects of this judgment, but this discussion shall only focus on those relating to the reasonableness of bonds. ${ }^{499}$

In this case ITLOS relied primarily on its own wisdom for the determination of a bond since Guinea had imposed none, and Saint Vincent and

\footnotetext{
${ }^{495}$ For a detailed discussion on the prompt release cases before the Tribunal up to the "Volga" Case, see Anne-Katrin Escher "Release of Vessels and Crews before the International Tribunal for the Law of the Sea" Part 3 (2004) 3 (3) LPICT 411.

${ }^{496}$ See Table - I Prompt Release Cases at ITLOS and Bonds Prescribed, 87.

${ }^{497}$ Serdy and Bliss, above n 488, 275.

498 Nigel K Meeson "A Prompt but Controversial Decision for Prompt Release: The Saiga" (1998) Lloyd's Maritime \& Commercial Law Quarterly 485. For a summary of the facts of the case, see Shabtai Rosenne "International Tribunal for the Law of the Sea: 1996-97 Survey" (1998) 13 (4) IJMCL 487, 512.

${ }^{499}$ See Vaughan Lowe "The M/V Saiga: The First Case in the International Tribunal for the Law of the Sea" (1999) 48 ICLQ 187; Edward Duncan Brown "The M/V 'Saiga' Case on Prompt Release of Detained Vessels: The First Judgment of the International Tribunal for the Law of the Sea" (1998) 22 (4-5) Marine Policy 307; Eli Lauterpacht "The First Decision of the International Tribunal for the Law of the Sea: The M/V Saiga" in Gerhard Hafner and others (eds) Liber Amicorum Professor Seidl-Hohenveldern - In Honour of His 80th Birthday (Kluwer Law International, The Hague, 1998) 395.
} 
the Grenadines had offered none either. ${ }^{500}$ Since no bond was sought by Guinea for the release of the $M / V$ "Saiga", the question of "discounting" the bond does not arise in this case. However, from the perspective of oceans governance, what needs to be noted in this case are some of the observations the Tribunal made with regard to the determination of the reasonableness of a bond.

ITLOS declared that the "criterion of reasonableness encompasses the amount, the nature and the form of the bond or financial security. The overall balance of the amount, form and nature of the bond or financial security must be reasonable." 501 Sadly, this test proposed by the Tribunal did "not advance matters beyond adding the elements of the form and nature of the security" whereas "[t]he crucial matter [was] its amount."502

ITLOS considered it reasonable to hold the amount of gasoil discharged from the holds of the $M / V$ "Saiga" as part of the security for its release. ${ }^{503}$ Since gasoil happens to be a commodity of commercial value and any attempt to restore the extracted gasoil to the holds of the $M / V$ "Saiga" would be difficult, the Tribunal's ruling to have this gasoil treated as a security by Guinea appears to be justified. The amount of gasoil discharged from the $M / V$ "Saiga" was declared by the Applicant to be $4,941.322$ metric tons ${ }^{504}$ and had a value of approximately $\$$ US $1,000,000 .{ }^{505}$ However, the Tribunal also considered it reasonable to add to this an additional financial security of \$ US 400,000 that Saint Vincent and the Grenadines would need to post with Guinea for the release of the $M / V$ "Saiga". ${ }^{506}$ It is noteworthy that the Tribunal in its judgment gave no indication as to the factors that it considered in ordering the bond. ${ }^{507}$

For a vessel that had a market price of $\$$ US $1,500,000,{ }^{508}$ a bond totalling to \$ US 1,400,000 seems to be quite justified. This appears justified because, in the subsequent cases that appeared on the Tribunal's docket, the Tribunal

\footnotetext{
${ }^{500}$ The $M / V$ “Saiga” Judgment, above n 487.

${ }^{501}$ The $M / V$ "Saiga” Judgment, above $\mathrm{n} 487$, para 82.

502 The "Camouco" Case, (Panama v France) (Prompt Release) [2000] <http://www.itlos.org/> (last accessed 1 December 2005) para 4 Judge Anderson dissenting.

${ }^{503}$ The $M / V$ "Saiga” Judgment, above n 487, para 84.

${ }^{504}$ The $M / V$ "Saiga" Judgment, above n 487, para 83.

${ }^{505}$ The $M / V$ "Saiga" Judgment, above n 487, para 35.

${ }^{506}$ The $M / V$ "Saiga" Judgment, above n 487, para 84.

${ }^{507}$ Bernard Oxman "The 'M/V Saiga' (Saint Vincent and the Grenadines v Guinea) ITLOS Case No 1" (1998) 92 AJIL 278, 281.

508 The vessel was insured for a value of \$ US 1,500,000. The M/V "Saiga" Judgment, above n 487, para 35 .
} 
specified several factors that need to be taken into account in the determination of a bond. One such factor happens to be the value of the vessel and cargo. ${ }^{509}$

However, in the same list of factors that the Tribunal laid down in the later "Camouco" Case, "gravity of the alleged offences" as well as the "penalties imposable under the laws of the detaining State" also featured prominently. Regrettably, in the $M / V$ "Saiga" Case, these factors did not occur to ITLOS in the determination of the bond. Further, according to the author, this judgment of ITLOS was not sufficiently reasoned.

2 The "Camouco" case

The second prompt release case lodged at the Tribunal's Registry and eventually decided, was the "Camouco" Case, filed by Panama against France. ${ }^{510}$ The "Camouco" was a fishing vessel flying the flag of Panama and engaged in longline fishing in the Southern seas around the end of September 1999. ${ }^{511}$ On 28 September 1999, when the "Camouco" was in the EEZ of the Crozet Islands, it was boarded and arrested by the French authorities. ${ }^{512}$ France alleged that the "Camouco" was in breach of certain French fishing laws and had been caught with 7,600 kilograms of Patagonian toothfish on board. ${ }^{513}$ The application for prompt release of the "Camouco" and its Master was brought before the Tribunal on 17 January 2000 and on 7 February 2000 the Tribunal delivered its judgment. ${ }^{514}$

During the proceedings, France requested the Tribunal to declare the application brought by Panama as inadmissible. ${ }^{515}$ In the alternative, it pleaded that the bond be set no lower than 20,000,000 French francs, basing it upon the bond that was determined by the court of first instance at Saint Paul in the Order of 8 October $1999 .^{516}$

\footnotetext{
509 The “Camouco" Case, (Panama v France) (Prompt Release) [2000] < http://www.itlos.org/> (last accessed 1 December 2005) para 67 Judgment of the majority [The "Camouco" Judgment].

${ }^{510}$ The "Camouco" Judgment, above n 509.

${ }^{511}$ The "Camouco" Judgment, above n 509, paras 25 and 27.

512 The "Camouco" Judgment, above n 509, para 28.

${ }^{513}$ The "Camouco" Judgment, above n 509, paras 29 and 33.

${ }^{514}$ The "Camouco" Judgment, above n 509, para 2.

${ }^{515}$ The "Camouco" Judgment, above n 509, para 24.

${ }^{516}$ The "Camouco" Judgment, above n 509, para 36.
} 
In its final submissions, Panama requested the Tribunal to order France to promptly release the "Camouco" and its Master against a reasonable bond of 1,300,000 French francs. ${ }^{517}$ In addition, Panama submitted that the sale price of the fish seized, amounting to 350,000 French francs and sold by the French authorities, be subtracted from the quantum of the bond. ${ }^{518}$ Therefore, Panama was only willing to pay a maximum amount of 950,000 French francs as an additional financial security to account for the total bond it was offering. ${ }^{519}$

While deliberating on the question of the reasonableness of the bond to be prescribed, the Tribunal reiterated some of the observations it had made in $M / V$ "Saiga” Case: ${ }^{520}$

[T] he criterion of reasonableness encompasses the amount, the nature, and the form of the bond or financial security. The overall balance of the amount, form and nature of the bond or financial security must be reasonable.

In addition to the above, the Tribunal also laid down an inclusive list of factors that it considered relevant in the assessment of the reasonableness of bonds or other financial security. According to the Tribunal, the relevant factors include: $:^{521}$

$[T]$ he gravity of the alleged offences, the penalties imposed or imposable under the laws of the detaining State, the value of the detained vessel and of the cargo seized, the amount of the bond imposed by the detaining State and its form.

This was an important development in the emerging jurisprudence of prompt release cases. Since the LOSC provides no definite yardsticks to measure the reasonableness of a bond, it is valuable that the world has the benefit of such necessary yardsticks emerging from judicial pronouncements. Explanations such as the Tribunal's one above play a significant role in understanding the criteria used in the determination of a reasonable bond. However, even this criteria laid down by the Tribunal has not been spared criticism, including that the criteria is "relatively limited and apparently mechanistic." 522

\footnotetext{
517 The “Camouco" Judgment, above n 509, para 24.

${ }^{518}$ The "Camouco" Judgment, above n 509, para 24.

${ }^{519}$ The "Camouco" Judgment, above n 509, para 24.

${ }^{520}$ The "Camouco" Judgment, above n 509, para 66.

${ }^{521}$ The "Camouco" Judgment, above n 509, para 67.

522 Malcolm D Evans "Bonded Reason: The Camouco" (2000) Lloyd's Maritime \& Commercial Law Quarterly 315, 321.
} 
Thereafter the Tribunal announced that it had taken into consideration the nature of the alleged offences as well as the nature of the penalties for the same under French national laws. ${ }^{523}$ ITLOS recorded France's submission that the maximum penalty imposable on the Master of the "Camouco" was 5,000,000 French francs. ${ }^{524}$ France had also submitted before ITLOS that under French law the owner of the "Camouco" could be criminally liable for a fine up to five times that imposed on the Master. ${ }^{525}$ However, the bond amount finally determined by ITLOS does not indicate that the Tribunal placed much weight on the gravity of the alleged offences as indicated by the heavy fines.

ITLOS also acknowledged that the value of the "Camouco" was disputed between the parties although that "alone may not be the controlling factor in the determination of the bond or other financial security." 526 Panama had, during the oral proceedings, offered expert testimony as to the value of the "Camouco" and this value of 3,717,571 French francs was left unchallenged by France. ${ }^{527}$

ITLOS ruled that the bond imposed by the French authorities was not reasonable ${ }^{528}$ though the "chain of reasoning that led it to that conclusion was not explained." 529 The Tribunal then pronounced a bond of 8,000,000 French francs that Panama would need to furnish in order to secure the release of the "Camouco" and its Master from detention. ${ }^{530}$ By doing so, ITLOS reduced the bond sought for the release by 60 per cent - from 20,000,000 French francs as originally sought by France to $8,000,000$ French francs. ${ }^{531}$ Again, the Tribunal failed to provide some indication as to how it arrived at the bond amount it had prescribed, ${ }^{532}$ and appeared "to pluck its figure for a reasonable bond ... out of thin air." ${ }^{, 53}$ Thus it appears that the Tribunal paid little regard, if any, to the fact that France had submitted before it that the maximum amount of fines imposable

\footnotetext{
${ }^{523}$ The "Camouco" Judgment, above n 509, para 24.

${ }^{524}$ The "Camouco" Judgment, above n 509, para 68.

${ }^{525}$ The "Camouco" Judgment, above n 509, para 68.

${ }^{526}$ The "Camouco" Judgment, above n 509, para 69.

${ }^{527}$ The "Camouco" Judgment, above n 509, para 69.

${ }^{528}$ The "Camouco" Judgment, above n 509, para 89.

${ }^{529}$ Vaughan Lowe "International Tribunal for the Law of the Sea: Survey for 2000" (2001) 16 (4) IJMCL 549, 559 ["International Tribunal for the Law of the Sea: Survey for 2000"].

${ }^{530}$ The "Camouco" Judgment, above n 509, para 74.

${ }^{531}$ See TABLE - I of present thesis, 87.

532 D J Devine "Prompt Release of Vessel and Master" (2000) 25 SAYIL 227, 230; Bernard H Oxman and Vincent P Bantz "Prompt Release of Vessels and Crews - Exhaustion of Local Remedies - Lis Pedens - Amount and Form of Reasonable Bond - UN Convention on the Law of the Sea" (2000) 94 AJIL 713.

533 "International Tribunal for the Law of the Sea: Survey for 2000", above n 529, 561.
} 
upon the Master and owners of the "Camouco" under French law could be more than 30,000,000 French francs. ${ }^{534}$ It also appears that the Tribunal did not expend much effort in looking beyond the value of the vessel as testified by the Panamanian expert.

This operative part of the judgment however was not a unanimous one and Judges Kolodkin, Anderson, Vukas, Wolfrum, Treves and Ndiaye voted against it. ${ }^{535}$ In this regard, it is worthwhile bringing out some of the issues that featured in the dissenting opinions of Judges Treves, Wolfrum and Anderson. ${ }^{536}$ This will demonstrate further that the Tribunal's judgment was not entirely justified in discounting the amount of the bond, and there are strong reasons for claiming so.

In his dissenting opinion, Judge Treves declared at the outset that he considered the amount of the bond prescribed as "too low in order to be 'reasonable' within the terms of article 292, paragraph 2, of the Convention." 537 First, he pointed out that the charges levelled against the Master appeared to lead to a plausible conviction and as one of the aims of the bond was to guarantee the payment of fines, it would be reasonable to consider the maximum fine imposable on the Master. ${ }^{538}$ Similarly, he pointed out that criminal liability that could attach to the owners of the vessel and the fines thereto under French law "should not be ignored." 539

Secondly, he opined that it would be reasonable to consider the value of the "Camouco" as not exceeding 5,750,000 French francs, as was previously indicated by the Panamanian interested parties before a French judicial authority. ${ }^{540} \mathrm{He}$ added that it also appeared justified to him that the Panamanian

\footnotetext{
${ }^{534}$ The “Camouco" Judgment, above n 509, para 64.

535 The "Camouco" Judgment, above n 509, para 78.

${ }^{536}$ On the value of dissenting and individual judgments in international courts and tribunals, see Ram Prakash Anand Studies in International Adjudication (Vikas Publications, Delhi, 1969) 191 - 217 [Studies in International Adjudication]. For the nature and extent of dissenting opinions in the cases before ITLOS, see David H Anderson "Deliberations, Judgments, and Separate Opinions in the Practice of the International Tribunal for the Law of the Sea" in M H Nordquist and J N Moore (eds) Current Marine Environmental Issues and the International Tribunal for the Law of the Sea (Kluwer Law International, The Hague, 2001) 63, 69 ["Deliberations, Judgments, and Separate Opinions in the Practice of the International Tribunal for the Law of the Sea"].

537 The "Camouco" Case, (Panama v France) (Prompt Release) [2000] <http://www.itlos.org/> (last accessed 1 December 2005) para 1 Judge Treves dissenting [The "Camouco" - Judge Treves dissenting].

${ }^{538}$ The "Camouco" - Judge Treves dissenting, above n 537, para 7.

${ }^{539}$ The "Camouco" - Judge Treves dissenting, above n 537, para 7.

${ }^{540}$ The "Camouco" - Judge Treves dissenting, above n 537, para 8.
} 
side deposit a higher bond with a view to maintain good relations with France in order to obtain licences to exploit the living resources in the French EEZ. ${ }^{541}$ Overall, it seemed to Judge Treves that the bond fixed by the Tribunal had failed to take into consideration a reasonable value of the "Camouco" and the criminal responsibility of the concerned parties, which could in due time be established. ${ }^{542}$

Judge Wolfrum, in his dissenting opinion, thought that the bond "as determined by the Tribunal [was] too low by far." ${ }^{543}$ He pointed out that in this case the fines that the Master and owners of the "Camouco" were liable to face happened to be significantly higher than the alleged value of the vessel. ${ }^{544} \mathrm{He}$ also criticised the judgment for not revealing whether the amount of the bond determined reflected predominantly the value of the "Camouco" or the fines faced by the parties concerned. ${ }^{545}$ He opined that the judgment had proved to be lacking in an objective analysis of the aims behind the requirement of posting such financial security and therefore bordered on "subjective justice." 546

Judge Anderson argued inter alia in his dissenting opinion that the competent court in Réunion was within its "margin of appreciation" ${ }^{\text {" }} 47$ in fixing the bond amount at 20,000,000 French francs, well below the maximum penalties ranging over 30,000,000 French francs. ${ }^{548} \mathrm{He}$ explained that, for the legitimate purposes of securing the payment of fines that might be imposed and the appearance of the accused at trial, this bond appeared appropriate. ${ }^{549}$ He stressed the point further by reminding the Tribunal that the appeal court had the opportunity to consider this question afresh and, had it found the inferior court in error, could have itself given relief. ${ }^{550}$ Concluding in this regard, he stated "[c]onsidering the facts and applying the terms of the Convention as a whole, it

\footnotetext{
${ }^{541}$ The “Camouco" - Judge Treves dissenting, above n 537, para 8.

${ }^{542}$ The "Camouco" - Judge Treves dissenting, above n 537, para 9.

543 The "Camouco" Case, (Panama v France) (Prompt Release) [2000] < http://www.itlos.org/> (last accessed 1 December 2005) para 16 Judge Wolfrum dissenting [The "Camouco" - Judge Wolfrum dissenting].

${ }^{544}$ The "Camouco" - Judge Wolfrum dissenting, above n 544, para 3.

${ }^{545}$ The "Camouco" - Judge Wolfrum dissenting, above n 544, para 16.

${ }^{546}$ The "Camouco" - Judge Wolfrum dissenting, above n 544, para 3.

547 A concept applied by the European Court of Human Rights in Handyside $v$ The United Kingdom (1976) 24 ECHR (Ser A) 49.

548 The "Camouco" Case, (Panama v France) (Prompt Release) [2000] <http://www.itlos.org/> (last accessed 1 December 2005) para 4 Judge Anderson dissenting [The “Camouco" - Judge Anderson dissenting].

549 The "Camouco" - Judge Anderson dissenting, above n 548, para 4.

${ }^{550}$ The "Camouco" - Judge Anderson dissenting, above n 548, para 4.
} 
has not been established, in my opinion, that the amount lies beyond the range of what is reasonable." $" 551$

Hence it can concluded that the decision of the majority in drastically reducing the bond amount was unacceptable, and could in the long run have unwarranted consequences for oceans governance. Some of these consequences will be analysed in the later sections of this part.

The "Monte Confurco" Case was the third prompt release matter to come before the Tribunal. The application for the prompt release of the "Monte Confurco" and its Master was brought on behalf of Seychelles against France on 27 November 2000. ${ }^{552}$ The "Monte Confurco" was flying the flag of Seychelles while engaged in longline fishing in the Southern seas when on 8 November 2000 French authorities in the EEZ of the Kerguelen Islands boarded it. ${ }^{553}$ An estimated 158 tons of Patagonian toothfish was found on board the "Monte Confurco" that was allegedly caught illegally. ${ }^{554}$

In the proceedings before ITLOS, France claimed that the amount of $56,400,000$ French francs as fixed by the court of first instance at Saint Paul was reasonable for the release of the "Monte Confurco" and its Master. ${ }^{555}$ Seychelles pleaded with the Tribunal to set a bond in the maximum amount of 2,200,200 French francs. ${ }^{556}$ Seychelles also requested the Tribunal to consider the value of the cargo, fishing gear, bait and gasoil amounting to 9,800,000 French francs, to form a part of the guarantee. ${ }^{557}$

In its judgment, the Tribunal indicated that in the assessment of a reasonable bond, the Tribunal would treat the laws of the detaining state and the decisions of its courts as relevant facts. ${ }^{558}$ In the same vein, it opined that the amount of the bond should not be excessive and unrelated to the gravity of the

\footnotetext{
${ }^{551}$ The “Camouco" - Judge Anderson dissenting, above n 548, para 24.

552 The "Monte Confurco" Judgment, above n 482, para 2.

${ }^{553}$ The "Monte Confurco" Judgment, above n 482, paras 27 and 29.

${ }^{554}$ The "Monte Confurco" Judgment, above n 482, para 34.

${ }^{555}$ The "Monte Confurco" Judgment, above n 482, paras 9 and 38.

556 The "Monte Confurco" Judgment, above n 482, para 25.

${ }^{557}$ The "Monte Confurco" Judgment, above n 482, para 26.

${ }^{558}$ The "Monte Confurco" Judgment, above n 482, para 72.
} 
alleged offences. ${ }^{559}$ In this context, the Tribunal has been criticised for sidestepping the question of how a situation needs to be handled where state practice varies from its statutory laws in the enforcement of fisheries laws, particularly on the issue of imprisonment. ${ }^{560}$

The Tribunal recalled its words from the judgment in the "Camouco" Case where it had pointed out a number of factors relevant to the assessment of a bond, including the gravity of the alleged offences, penalties prescribed under the laws of the detaining state, value of the vessel and its cargo and the amount and form of the bond sought by the detaining state. ${ }^{561}$ However the Tribunal clarified that this could by no means be deemed as a complete list of factors. It also mentioned specifically that it did not "intend to lay down rigid rules as to the exact weight to be attached to each of them."562

In the "Monte Confurco" Case, the Tribunal also affirmed that it "considers that the value of the fish and of the fishing gear seized is also to be taken into account as a factor relevant in the assessment of the reasonableness of the bond", ${ }^{563}$ which had to be deducted from the bond to be paid. However, the Tribunal found that the bond of 56,400, 000 French francs as imposed by the French court was not "reasonable" within the meaning of Article 292 of the Convention. ${ }^{564}$ In its judgment of 18 December 2000, the Tribunal ruled by 17 votes to three that the reasonable bond for the release of the "Monte Confurco" and its Master should be a total of 18,000,000 French francs. ${ }^{565}$ The Tribunal held that this bond would be comprised of two parts $-9,000,000$ French francs as the monetary equivalent of 158 tons of fish as already held by the French authorities and 9,000,000 French francs to be posted with France. ${ }^{566}$

Therefore, the Tribunal in prescribing a reasonable bond totalling to $18,000,000$ French francs, reduced the bond of 56,400,000 French francs as

\footnotetext{
${ }^{559}$ The “Monte Confurco” Judgment, above n 482, para 73.

${ }^{560}$ LOSC, art 73(2) prohibits imprisonment and corporal punishment for the infringement of fisheries laws in the EEZ by foreign vessels. See William R Edeson "A Brief Introduction to the Principal Provisions of the International Legal Regime Governing Fisheries in the EEZ" in Syma A Ebbin, Alf Hakon Hoel and Are K Sydnes (eds) A Sea Change: The Exclusive Economic Zone and Governance Institutions for Living Marine Resources (Springer, Dodrecht, 2005) 17, 24.

${ }^{561}$ The "Monte Confurco" Judgment, above n 482, para 76.

${ }^{562}$ The "Monte Confurco" Judgment, above n 482, para 76.

${ }^{563}$ The "Monte Confurco" Judgment, above n 482, para 86.

${ }^{564}$ The "Monte Confurco" Judgment, above n 482, para 89.

${ }^{565}$ The "Monte Confurco" Judgment, above n 482, para 93.

${ }^{566}$ The "Monte Confurco" Judgment, above n 19, para 93.
} 
sought by France by 68.09 per cent. ${ }^{567}$ Compared to the "Camouco" Case, this was an even greater reduction in the amount of the bond that the Tribunal had allowed, from what had been originally sought by France in both cases, as the detaining state. Thus just like the "Camouco" Case, the Tribunal had paid little regard, if any, to the fact that the fines likely to be incurred by the Master of the "Monte Confurco" could be as high as 79,000,000 French francs ${ }^{568}$ if proven guilty of the alleged offences.

The Tribunal was also said to have "second-guessed the French court" and was "in danger of straying into territory that properly belongs to the local court" by opining that not all of the catch could have been taken from the Kerguelen EEZ. ${ }^{569}$ The alleged offences were obviously deemed by France to be of a grave and serious nature as evident from the heavy fines that were imposable on conviction. Perhaps if the Tribunal had taken due consideration of the gravity of the alleged offences and the fines imposable under the laws of the detaining state - both criteria it had spelt out in the "Camouco" and the "Monte Confurco" Cases, it would have found it fitting to prescribe a higher bond as reasonable. This alarming omission on the Tribunal's part stands out all the more in view of some of the recollections and observations made by it in the judgment of the “Monte Confurco" Case: ${ }^{570}$

\begin{abstract}
The Respondent has pointed out that the general context of unlawful fishing in the region should also constitute one of the factors which should be taken into account in assessing the reasonableness of the bond. In its view, this illegal fishing is a threat to the future resources and the measures taken under CCAMLR for the conservation of toothfish. The Respondent states that '[a]mong the circumstances constituting what one might call the 'factual background' of the present case, there is one whose importance is fundamental. That is the general context of unlawful fishing in the region concerned.' The Tribunal takes note of this argument.
\end{abstract}

It appears to the author that the Tribunal took note of the argument but the deficiency in according it the importance it deserved was reflected in its judgment determining a bond of 18,000,000 French francs as reasonable - far below the amount sought by the detaining state.

\footnotetext{
${ }^{567}$ See TABLE - I of present thesis, 87.

${ }^{568}$ The “Monte Confurco" Judgment, above n 482, para 38.

${ }^{569}$ International Tribunal for the Law of the Sea: Survey for 2000", above n 529, 566.

${ }^{570}$ The "Monte Confurco" Judgment, above n 482, para 79 (emphasis added).
} 
In this regard, some of the observations of Judge Anderson recorded in his dissenting opinion to the judgment of the Tribunal are noteworthy. Judge Anderson opined that the French court was correct in its approach in determining a reasonable bond for the release of the "Monte Confurco" and its crew. ${ }^{571} \mathrm{He}$ noted that under French law in the present case, the maximum fine for illegal fishing was directly linked to the amount of illegally caught fish. ${ }^{572} \mathrm{He}$ added that the French court in fixing the bond had exercised discretion normally available worldwide in proceedings for release on bail, and had taken into account half of the 158 tons of fish found on the "Monte Confurco". ${ }^{573} \mathrm{He}$ also mentioned that the domestic court had certain discretion or margin of appreciation in these cases and the French court had fixed the bond well below the amount of the maximum fine. Therefore given this understanding and appreciating the general need to curb illegal fishing in the region, the French court did not exceed its margin in the present case. ${ }^{574}$ In addition, the Judge pointed to the Tribunal's observation in paragraph 73 of its judgment - "[t]he Tribunal is of the view that the amount of the bond should not be excessive and unrelated to the gravity of the alleged offences. ${ }^{\circ 75}$ He then stated that in the present case: ${ }^{576}$

[T] he amount of the bond was directly linked to the charge of illegal fishing in the EEZ and to the fines available to the court in the event of a conviction under the law in force around the Kerguelen Islands.

This dissenting judgment of Judge Anderson reflects a strong criticism of the Tribunal's tendency to reduce substantially the bonds sought by detaining states for the release of detained vessels and crews. Arguing on a different plane, Judge Jesus in his dissenting opinion concluded that the Tribunal had unduly

\footnotetext{
571 See The "Monte Confurco" Case (Seychelles v France) (Prompt Release) [2000] $<$ http://www.itlos.org/> (last accessed 1 December 2005) paras 3 - 5 Judge Anderson dissenting [The "Monte Confurco" - Judge Anderson dissenting].

572 The "Monte Confurco" - Judge Anderson dissenting, above n 571, para 4.

${ }^{573}$ The "Monte Confurco" - Judge Anderson dissenting, above n 571, para 5.

${ }^{574}$ The "Monte Confurco" - Judge Anderson dissenting, above n 571, para 5.

${ }^{575}$ The "Monte Confurco" - Judge Anderson dissenting, above n 571, para 6.

${ }^{576}$ The "Monte Confurco" - Judge Anderson dissenting, above n 571, para 6.
} 
gone into the merits of the case and failed to preserve the balance of interests between the flag state and the coastal state. ${ }^{577}$

The dissenting judgments support the author's argument that in light of coastal states' endeavours to curb illegal fishing, a huge reduction of the bond as sought by France, does not have constructive implications for oceans governance.

\section{The "Volga" case}

The "Volga" Case entered the Tribunal's list of cases as the sixth prompt release matter brought under Article 292 of the Convention. ${ }^{578}$ This application saw Australia responding to the case filed by the Russian Federation before the Tribunal on 2 December 2002. ${ }^{579}$ The "Volga" was a long-line fishing vessel flying the Russian flag and like the "Monte Confurco", was engaged in fishing in the Southern Seas. On 7 February 2002 it was boarded and apprehended by Australian authorities for infringement of the fishery laws in force ${ }^{580}$ in the EEZ of the sub - Antarctic Australian Territory of Heard Island and the McDonald Islands. ${ }^{581}$ Again, as with the "Camouco" and "Monte Confurco", the catch discovered in the holds of the "Volga" comprised of Patagonian toothfish. ${ }^{582}$ Australia claimed that 131.422 tons of Patagonian toothfish had been found on the "Volga" along with 21.494 tons of bait, which were later sold for AU\$

\footnotetext{
577 The "Monte Confurco" Case (Seychelles V France) (Prompt Release) [2000] $<$ http://www.itlos.org/> (last accessed 1 December 2005) para 7 Judge Jesus dissenting [The "Monte Confurco" - Judge Jesus dissenting].

578 The Tribunal did not have occasion to prescribe a reasonable bond in the "Grand Prince" Case and the "Chaisiri Reefer 2" Case that happened to be the fourth and fifth prompt release cases to have entered its docket. In the former, the Tribunal held that it had no jurisdiction to hear the Application and the parties to the dispute withdrew the latter on the ground that they had mutually reached an agreement for the release of the vessel.

579 The "Volga" Case, (Russian Federation v Australia) Case No 11 (Prompt Release) [2002] $<$ http://www.itlos.org/> (last accessed 1 December 2005) Judgment of the majority [The "Volga" Judgment].

${ }^{580}$ For detailed discussions on Australian law enforcement in various maritime zones, see Ivan A Shearer "Enforcement of Laws Against Delinquent Vessels in Australia's Maritime Zones" in Doug MacKinnon and Dick Sherwood (eds) Policing Australia's Offshore Zones: Problems and Prospects (Centre for Maritime Policy, University of Wollongong, Wollongong, 1997) 239; Tim Stephens "Enforcing Australian Fisheries Laws: Testing the Limits of Hot Pursuit in Domestic and International Law" (2004) 15 (1) PLR 12; Rachel Baird "Testing the Waters: Fine Tuning the Provisions of the Fisheries Management Act 1991 (Cth) Applicable to Foreign Fishing Boats" (2004) 32 UWAL Rev 63.

${ }^{581}$ The "Volga" Judgment, above n 579, para 32.

582 See The "Volga" Judgment, above n 579, para 51.
} 
1,932,579.28. ${ }^{583}$ The valuation report prepared by Australia for bonding purposes, valued the "Volga" at US\$ 1,000,000 and the fuel, lubricants, and equipment at a total of AU\$ 147,460. ${ }^{584}$ The three members of the crew aboard the "Volga", all of whom were Spanish nationals, were charged under local applicable laws in the Court of Petty Sessions of Western Australia on 6 March $2002 .^{585}$

In accordance with Article 75(2) of the Rules of the Tribunal, Russia in its final submissions requested the Tribunal inter alia to order Australia to release the "Volga" and its crew for a sum not exceeding AU\$ 500,000. ${ }^{586}$ When the case was pending at the Tribunal, on 21 December 2002, Australia confirmed that the three crew members had been released on bail and had departed Perth, Australia for Madrid. ${ }^{587}$ Under the provisions of the Fisheries Management Act 1991 of Australia, the forfeiture of the Volga and its equipment was entirely possible. ${ }^{588}$ However, aware of such legal provisions, the owner of the "Volga" instituted proceedings in the Court of Australia to prevent inter alia, the forfeiture of the "Volga" and its equipment. ${ }^{589}$ Then the Australian Fisheries Management Authority (AFMA) sought the lodgement of a security of AU\$ 3,332,500 for its release. ${ }^{590}$ AFMA had based the security amount it sought as reasonable on three elements: assessed value of the vessel, fuel, lubricants and fishing equipment (AU\$ 1,920,000), potential fines (AU\$ 412,500) and carriage of a fully functional VMS (Vessel Monitoring System), and observance of Convention on the Conservation of Antarctic Marine Living Resources (CCAMLR) ${ }^{591}$ conservation measures until the conclusion of legal proceedings (AU\$ $1,000,000) .{ }^{592}$

The Tribunal in the course of the proceedings found that it had jurisdiction to deal with the dispute. ${ }^{593}$ Enquiring into the reasonableness of the

\footnotetext{
${ }^{583}$ The "Volga" Judgment, above n 579, para 51.

${ }^{584}$ The "Volga" Judgment, above n 579, para 37.

${ }^{585}$ The "Volga" Judgment, above n 579, para 38.

586 The "Volga" Judgment, above n 579, para 51.

587 The "Volga" Judgment, above n 579, para 49.

${ }^{588}$ See The "Volga" Judgment, above n 579, para 50.

589 The "Volga" Judgment, above n 579, para 52.

${ }^{590}$ The "Volga" Judgment, above n 579, para 53.

${ }^{591}$ Convention on the Conservation of Antarctic Marine Living Resources (1 August 1980) 1329 UNTS 47.

592 The "Volga" Judgment, above n 579, paras 53 and 72.

${ }^{593}$ See The "Volga” Judgment, above n 579, paras 55 - 59.
} 
bond, the Tribunal noted Australia's contention that the bond sought was reasonable in light of the value of the vessel, gravity of the offences, increasing international concern over illegal fishing and the need to secure compliance with its laws and international obligations pending the completion of the domestic proceedings. ${ }^{594}$ Turning to its previous judgments, the Tribunal quoted itself from the "Camouco" Case where it had spelt out a number of factors that it considered relevant in the assessment of a reasonable bond. The Tribunal then recalled its words from the "Monte Confurco" Case where it had confirmed that neither did those factors form an exhaustive list nor did it intend to lay down one. ${ }^{595}$

Embarking on the assessment of whether the bond sought by Australia was reasonable in terms of the Convention, ITLOS recapitulated some of its observations in the "Monte Confurco" Case: ${ }^{596}$

\begin{abstract}
[T]he object of article 292 of the Convention is to reconcile the interest of the flag State to have its vessel and its crew released promptly with the interest of the detaining State to secure appearance in its court of the Master and the payment of penalties.

The balance of interests emerging from articles 73 and 292 of the Convention provides the guiding criterion for the Tribunal in its assessment of the reasonableness of the bond.
\end{abstract}

The Tribunal then added that, in the assessment of the reasonableness of the bond, "due account must be taken of the terms of the bond or security set by the detaining State, having regard to all the circumstances of the particular case." 597

The Tribunal ultimately found that a sum of AU\$ 1,920,000 was reasonable for the release of the Volga, its fuel, lubricants and fishing equipments. ${ }^{598}$ By doing so, the Tribunal reduced the bond amount sought by Australia by AU\$ $1,412,500$, or 42.39 per cent. ${ }^{599}$ The majority of the Tribunal found by 19 votes to two that a bond of the above amount was to be posted with

\footnotetext{
${ }^{594}$ The "Volga” Judgment, above n 579, paras 61.

595 The "Monte Confurco" Judgment, above n 482, para 76 and The "Volga” Judgment, above n 579 , para 64

596 The "Monte Confurco" Judgment, above n 482, paras 71 and 72, and The "Volga" Judgment, above n 579, para 65.

${ }^{597}$ The "Volga" Judgment, above n 579, para 65.

${ }^{598}$ The "Volga" Judgment, above n 579, para 90.

${ }^{599}$ See TABLE - I of present thesis, 87.
} 
Australia, with Judge Anderson and Judge ad hoc Shearer dissenting. ${ }^{600}$ The Tribunal seems to have employed little inventiveness in coming up with the above figure. It had previously expressed its opinion that AU\$ 1,920,000 represented the full value of the vessel, fuel, lubricants and fishing equipment as assessed by Australia and was reasonable in terms of Article 292 of the Convention. ${ }^{601}$ Indeed, AU\$ 1,920,000 simply formed a part of the AU\$ 3,332,500 bond that Australia sought and had accounted for as representing a security to merely cover the assessed value of the vessel, fuel, lubricants and fishing equipment.

The Tribunal has gone on record time and again in deciphering the meaning of "reasonable bond" and has so far come up with a number of factors that it considers relevant in its assessment. Nevertheless, it appears to the author that the bond amount it prescribed in the "Volga" Case does not reflect any consideration that it may have been given to such factors. Take for instance the factor of "the gravity of the alleged offences." In the present case, the Tribunal had engaged in a detailed discussion about the gravity of the alleged offences as clearly stressed by Australia in its pleadings ${ }^{602}$ but "simply appears to have discounted this broader factual matrix through adopting the narrow interpretation" ${ }^{\prime 63}$ of Article 292. However, when one looks at the final figure of the bond as prescribed by ITLOS, one finds no indication of the element of the gravity of the alleged offences to be a part of such bond. As seen above, the bond amount simply reflects the value of the vessel, fuel, lubricant and fishing equipment. The Tribunal also made no effort to explain after pronouncing the bond what portion of it was in consideration of the gravity of the alleged offences, if any.

In the same vein of the gravity of alleged offences, it is worthwhile to discuss an important element of the bond that Australia had sought. As mentioned previously, of the AU\$ 3,332,500 claimed by Australia, AU\$

\footnotetext{
${ }^{600}$ The "Volga" Judgment, above n 579, para 95(5).

${ }^{601}$ The "Volga" Judgment, above n 579, para 73.

${ }^{602}$ See The "Volga" Judgment, above n 579, para 67.

${ }^{603}$ Donald R Rothwell and Tim Stephens "The 'Volga' Case (Russian Federation v Australia): Prompt Release and the Right and Interests of Flag and Coastal States" in Conference Proceedings - Multilateralism and International Ocean - Resources Law (Paper 20031, Law of the Sea Institute, University of California, Berkeley, 2003) IX-8 $<\mathrm{http}: / /$ repositories.cdlib.org/losi/cp/20031/> (last accessed 7 September 2005).
} 
$1,000,000$ featured as a security related to the carriage of a fully operational $\mathrm{VMS}^{604}$ on the "Volga" and observance of CCAMLR conservation measures. ${ }^{605}$ Australia had contended that carriage of the VMS was necessary in order to prevent further illicit fishing once the vessel was released and the Tribunal took note of this argument. ${ }^{606}$

On Australia's repeated submissions, the Tribunal also declared that it had taken note of the gravity of the alleged offences and understood the international concerns about IUU fishing, and appreciated the objectives behind the measures taken by states parties to CCAMLR to deal with the problem. ${ }^{607}$ The Tribunal clarified that it did not consider it appropriate under the ongoing proceedings to consider whether a coastal state was entitled to impose such conditions in its exercise of sovereign rights under the Convention. ${ }^{608}$ It pointed out that under the ongoing proceedings it was only necessary to decide whether the words "bond or security" as mentioned in Article 73(2) could be intended to include such conditions. Treves has submitted that the Tribunal was not altogether "insensitive" to the appeals made to it with respect to the problem of IUU fishing but was "restrained" in its response since it did not consider it possible to go beyond the stance it had taken. ${ }^{609}$ However, the Tribunal's decision that "accorded little weight to the serious problem of IUU fishing",610 has attracted some critical notes from commentators.

Another controversial aspect of the Tribunal's judgment is its rejection of Australia's conditions for the release of the "Volga". Article 73 is concerned

\footnotetext{
${ }^{604}$ For a discussion the importance of VMSs in current oceans governance, see Erik Jaap Molenaar and Martin Tsamenyi "Satellite Based Vessel Monitoring Systems (VMSs) for Fisheries Management - International Legal Aspects and Developments in State Practice" (FAO Legal Paper Online \#7, April 2000) available at $<$ http://www.fao.org/Legal/prs-ol//po7.pdf $>$ (last accessed 20 October 2005).

${ }^{605}$ For a report on some CCAMLR conservation measures including the use of a centralised VMS, see Alan D Hemmings "Managing the Southern Ocean - the 2003 Meeting of the Commission for the Conservation of Antarctic Marine Living Resources" (2004) 1 NZYIL 199.

${ }^{606}$ The "Volga" Judgment, above n 579, para 75.

${ }^{607}$ The "Volga" Judgment, above n 579, para 68.

${ }^{608}$ The "Volga" Judgment, above n 579, para 76.

${ }^{609}$ Tullio Treves "Flags of Convenience Before the Law of the Sea Tribunal" (2004) 6 San Diego Intl L J 179, 183 - 184. ["Flags of Convenience Before the Law of the Sea Tribunal"].

${ }^{610}$ Tim Stephens and Donald R Rothwell "Law of the Sea: An Article 292 Bond Must be Reasonable in Amount in Light of Both the Interest of a Flag State in the Prompt Release of its Fishing Vessel and that of the Coastal State in Securing the Appearance of the Master in Court and the Payment of Fines; It Cannot Include an Amount Guaranteeing Future 'Good Behaviour,' and the Value of the Catch is Irrelevant to its Calculation. The Volga (Russian Federation v Australia) ITLOS No11 (23 December 2002)" (2004) 35 J Mar L \& Com 283, 288 ["Law of the Sea: An Article 292 Bond"].
} 
with the enforcement of laws and regulations of the coastal state and paragraph 2 simply provides that "[a]rrested vessels and their crews shall be promptly released upon the posting of reasonable bond or other security." 611 However, the Tribunal chose to agree with the arguments of Russia in holding that Article 73 (2) of the Convention provided no basis for the imposition of non-pecuniary conditions as components of a bond for the prompt release under Article $290 .{ }^{612}$

The Tribunal reasoned that the expression "bond or other security" in Article 73(2) should be seen in its context and in light of its object and purpose. ${ }^{613}$ However, it was content in simply exploring its "context" to look at other provisions in the Convention that relate to the prompt release of vessels and crews upon the posting of a reasonable bond or security. ${ }^{614}$ Pointing to Articles 292, 220(7), and 226(1)(b), the Tribunal stated that the provisions use expressions such as "bond or other financial security" and "bonding or other appropriate financial security". ${ }^{615}$ The Tribunal also observed that where the Convention envisages the imposition of conditions additional to a bond or other financial security, it expressly states so. ${ }^{616}$ Therefore, the Tribunal concluded that non-financial conditions (good behaviour bond) such as the carriage of a VMS could not be considered as a component of the bond and doing so would defeat the object and purpose of Article 73(2) read with Article 292. ${ }^{617}$

This author respectfully differs from the reasoning of the Tribunal's majority. The Tribunal's reasoning is based upon a narrow interpretation of Article 73(2) that is unwarranted in the present case. There is considerable support in this regard in the dissenting opinion of Judge Anderson whose dissent was concerned with the single issue of the validity of non-financial conditions in bail bonds. ${ }^{618}$ Judge Anderson argued that a plain reading of the words of Article

\footnotetext{
${ }^{611}$ LOSC, art 73(2).

${ }^{612}$ The "Volga" Judgment, above n 579, paras 75 and 77.

${ }^{613}$ The "Volga" Judgment, above n 579, para 77.

${ }^{614}$ The "Volga" Judgment, above n 579, para 77.

${ }^{615}$ The "Volga" Judgment, above n 579, para 77.

${ }^{616}$ The Tribunal pointed to Art 226(1)(c) of the Convention that provides that "the release of the vessel may, wherever it would present an unreasonable threat of damage to the marine environment, be refused or made conditional upon proceeding to the nearest appropriate repair yard". The "Volga" Judgment, above n 579, para 77.

${ }^{617}$ The "Volga" Judgment, above n 579, para 77.

618 The "Volga" Case (Russian Federation $v$ Australia) (Prompt Release) [2002] $<\mathrm{http}$ ://www.itlos.org/> (last accessed 1 December 2005) para 1 Judge Anderson dissenting [The "Volga" - Judge Anderson dissenting].
} 
73 reveals no explicit restriction upon the imposition of non-financial conditions for the release of arrested vessels. ${ }^{619}$

It needs to be noted that where the Convention intends to limit the right of coastal states, it does so in express terms, as in the case of Article 73(3) that explicitly prohibits imprisonment and corporal punishment. ${ }^{620}$ Judge Anderson argued at length on the meaning of the expression "bond" 621 and concluded that, in the context of Article 73(2), its connotation is a legal one and "precisely that of release of an accused person against a bail bond which may, and often does, contain non-pecuniary conditions."

Judge ad hoc Shearer also expressed his strong dissent from the majority judgment of the Tribunal with regard to its dismissal of the so called "good behaviour bond" sought by Australia. ${ }^{623}$ He argued: ${ }^{624}$

\begin{abstract}
The words "bond" and "financial security" should be given a liberal and purposive interpretation in order to enable the Tribunal to take full account of the measures - including those made possible by modern technology - found necessary by many coastal States (and mandated by regional and sub-regional fisheries organizations) to deter by way of judicial and administrative orders the plundering of the living resources of the sea.
\end{abstract}

Australia's well-meaning efforts towards the conservation of marine living resources in its EEZs were arguably defeated by the Tribunal's decision. ${ }^{625}$ The environmental side of oceans governance that the Tribunal could have been a vanguard for in the present case was totally ignored. The environmental conservation purposes of the LOSC "would appear to have been dealt a blow by this aspect of the Tribunal's judgment.",626

However, White and Knight have called the assessment of a bond a mere mechanical exercise and suggested that: ${ }^{627}$

\footnotetext{
${ }^{619}$ The "Volga" - Judge Anderson dissenting, above n 618, para 7.

${ }^{620}$ The "Volga" - Judge Anderson dissenting, above n 618, para 7.

${ }^{621}$ See The "Volga" - Judge Anderson dissenting, above n 618, paras 9 - 12.

${ }^{622}$ The "Volga" - Judge Anderson dissenting, above n 618, para 13.

${ }^{623}$ The "Volga" Case, (Russian Federation V Australia) (Prompt Release) [2002] $<$ http://www.itlos.org/> (last accessed 1 December 2005) para 16 Shearer dissenting [The "Volga" - Shearer dissenting].

${ }^{624}$ The "Volga" - Shearer dissenting, above n 623, para 17.

${ }^{625}$ Ryszard Piotrowicz "The Song of the Volga Boatmen - Please Release Me" (2003) 77 ALJ $160,163$.

${ }^{626}$ Chester Brown "'Reasonableness' in the Law of the Sea: The Prompt Release of the Volga" (2003) 16 LJIL 621, 630.

${ }^{627}$ Michael White and Stephen Knight "ITLOS and the 'Volga' Case: The Russian Federation v Australia" (2003) 17 MLAANZ Journal 39, 51.
} 
[T]he Tribunal is correct in sticking to these mechanical steps and not going down the more emotive path of looking to penalise the vessel and its owners through the posting of a higher bond than is otherwise suitable.

Nevertheless, it needs stressing that no matter how procedural or mechanical a legal provision may be courts and tribunals are not required to interpret the law mechanically but purposefully and meaningfully. ${ }^{628}$

However, having recorded the considerable reduction in the bond amount in this case, it bears remembering that a significant portion of the bond that Australia sought was to the amount of AU\$ 412,500, which was to secure the payment of potential fines imposable on the crew pending the completion of the criminal proceedings in Australia. Since the crew members had subsequently been released on bail as ordered by the Supreme Court of Western Australia during the pendency of the proceedings at ITLOS, the amount of AU\$ 412,500 no longer needed consideration in assessment of a reasonable bond. ${ }^{629}$

In sum, the factor of "penalties imposed or imposable under the laws of the detaining State" did not warrant consideration in the assessment of the reasonableness of the bond. The Tribunal rightly pointed out that since the crew members had been released from detention, it served no practical purpose in setting a bond in that respect. ${ }^{630}$ Some commentators have pointed out that ITLOS did not mention that asking for additional security for the release of crew members over and above security provided for the vessel in question is unreasonable under Article 292. ${ }^{631}$

Overall, the judgment in the "Volga" Case "can be considered a milestone in the development of the jurisprudence of the Tribunal" 632 that has significant impact on oceans governance, not all of which is welcome. No wonder one commentator fears that the ITLOS's decision will: ${ }^{633}$

\footnotetext{
${ }^{628}$ Xenophon J Paparrigopoulos "The Role of Courts in Crisis and Transition Periods: Courts as Image Makers" in Shimon Shetreet (ed) The Role of Courts in Society (Martinus Nijhoff Publishers, Dordrecht, 1988) 68, 69.

${ }^{629}$ See The "Volga” Judgment, above n 579, para 74.

${ }^{630}$ The "Volga" Judgment, above n 579, para 74.

${ }^{631}$ White and Knight, above n 627, 47.

${ }^{632}$ Judge Dolliver Nelson, President ITLOS "The Volga Case" in 2003 Frank Stuart Dethridge Memorial Address, MLAANZ Annual Conference (Brisbane, 2003) reproduced in (2004) 18 MLAANZ Journal 7, 13.

${ }^{633}$ Warwick Gullett "Prompt Release Procedures and the Challenge for Fisheries Law Enforcement: The Judgment of the International Tribunal for the Law of the Sea in the 'Volga' Case (Russian Federation v Australia)" (2003) 31 Fed L Rev 395.
} 
... increase the prospect of owners of detained foreign vessels requesting their national authorities to utilise the prompt release procedures as a means to evade strict coastal state fisheries laws, thus undermining national or regional fisheries management measures.

Donald Rothwell suggests that the implications of the judgment in the "Volga" Case are such that "it would be a mistake for coastal States to expect too much of the Tribunal in future prompt release cases." ${ }^{634}$ Applying the litmus test $^{635}$ of whether the decision has a constructive impact on oceans governance, particularly with respect to the endangered Patagonian toothfish fishery, the answer is an unfortunate 'no'.

5

The "Juno Trader" case

The Tribunal witnessed once again the appearance of Saint Vincent and the Grenadines before it as an Applicant in yet another prompt release matter. The "Juno Trader" Case entered the Tribunal's docket on 18 November 2004 as its seventh prompt release case with Guinea-Bissau as the Respondent. ${ }^{636}$ The "Juno Trader" was a reefer vessel (refrigerated cargo vessel) flying the flag of Saint Vincent and the Grenadines, and held a permanent Certificate of Registry to transport refrigerated dry products. ${ }^{637}$ According to the Applicant, the "Juno Trader" had received a transhipment comprising of 1,183.8 tons of frozen fish and 112 tons of fish meal in Mauritanian waters from its sister ship, the "Juno Warrior" from 19 to 23 September 2004. ${ }^{638}$ From there, the "Juno Trader" crossed into the EEZ of Guinea-Bissau on 26 September 2004, bound for Ghana, its destination for the discharge of the cargo. ${ }^{639}$ Shortly thereafter, the "Juno Trader" was boarded by the officers of the Fisheries Inspection Service of Guinea-Bissau for infractions of fisheries laws applicable in the EEZ of Guinea-

\footnotetext{
${ }^{634}$ Donald R Rothwell "Oceans Management and the Law of the Sea in the Twenty-First Century" in Alex G Oude Elferink and Donald R Rothwell (eds) Oceans Management in the 21st Century: Institutional Frameworks and Responses (Martinus Nijhoff Publishers, Leiden, 2004) $329,348$.

${ }_{635}$ Ted L McDorman "International Tribunal for the Law of the Sea" (2002) 13 YIEL 673, 676.

${ }^{636}$ The "Juno Trader" Case (Saint Vincent and the Grenadines $v$ Guinea-Bissau) (Prompt Release) [2004] <http://www.itlos.org/> (last accessed 1 December 2005) [The "Juno Trader" Judgment].

${ }^{637}$ The "Juno Trader" Judgment, above n 636, paras 33 and 34.

${ }^{638}$ The "Juno Trader" Judgment, above n 636, para 35.

${ }^{639}$ The "Juno Trader" Judgment, above n 636, paras 35 and 36.
} 
Bissau. ${ }^{640}$ Saint Vincent and the Grenadines contended that the Juno Trader had been subjected to the use of force in its apprehension and boarding that led to the injury of a crew member aboard it. ${ }^{641}$ Guinea-Bissau claimed that the presence of the "Juno Trader" in its EEZ was "unknown and undeclared" and the notice of serious fishing infraction reported that the vessel had attempted to evade lawful inspection by fleeing, and had not heeded the instructions that were sent to it asking for cooperation and compliance. ${ }^{642}$

Inspection and analysis of the fish found aboard the "Juno Trader" at the instance of the National Fisheries Inspection and Control Service of GuineaBissau led to an incriminating report. ${ }^{643}$ This report concluded that all of the species identified on board the "Juno Trader" were found in the waters of Guinea-Bissau except for one species, which was "occasionally found." 644 On the basis of this report, the Fisheries Control Technical Committee of GuineaBissau (the Committee) proceeded to consider the offences committed in this case and made its proposals for actions to be taken. ${ }^{645}$

In the final submissions before the ITLOS, Saint Vincent and the Grenadines requested it to issue, inter alia, an order directing the release of the "Juno Trader" and its crew from detention. ${ }^{646}$ This was accompanied by the request to ITLOS to determine a reasonable bond or security on the posting of which Guinea-Bissau would be bound to carry out the release of the vessel and its crew. ${ }^{647}$ On 18 November 2004, the Shipownwers Protection Limited, acting as the Protection and Indemnity Club of the owners of the "Juno Trader", had deposited a bond of EUR 50,000 with the authorities of Guinea-Bissau for the release of the vessel and its crew. ${ }^{648}$

Guinea-Bissau on the other hand argued inter alia that in the event the Tribunal decided to order the release of the "Juno Trader", it should determine the amount of the bond at no less than EUR 1,227,214. ${ }^{649}$ Guinea-Bissau did not

\footnotetext{
${ }^{640}$ The "Juno Trader” Judgment, above n 636, para 39.

${ }^{641}$ The “Juno Trader” Judgment, above n 636, para 37.

${ }^{642}$ The “Juno Trader” Judgment, above n 636, para 38.

${ }^{643}$ The "Juno Trader" Judgment, above n 636, para 41.

${ }^{644}$ The "Juno Trader" Judgment, above n 636, para 41.

${ }^{645}$ The "Juno Trader" Judgment, above n 636, para 41.

${ }^{646}$ The “Juno Trader” Judgment, above n 636, para 31.

${ }^{647}$ The “Juno Trader” Judgment, above n 636, para 31.

${ }^{648}$ The "Juno Trader" Judgment, above n 636, para 51.

${ }^{649}$ The “Juno Trader” Judgment, above n 636, para 31.
} 
provide any reason for demanding the particular sum, justifiable under definite heads. However, it needs to be pointed out that the Interministerial Maritime Control Commission of Guinea-Bissau (IMCC) had considered the proposals made by the Committee and reiterated that a total fine of EUR 184,168 had to be paid to Guinea-Bissau for the fishing infractions. ${ }^{650}$ This fine comprised of two parts - EUR 175,398 on the "Juno Trader" and EUR 8,770 on its captain for the offences committed. ${ }^{651}$ The fine imposed on the captain had been duly paid by the ship-owner on 3 November 2004 without any admission of guilt but the fine on the vessel was not paid. ${ }^{652}$

In the meanwhile, the ship-owner approached the Regional Court of Bissau and obtained from the court an order on 23 November 2004, five days after the institution of the "Juno Trader" Case at the Tribunal. ${ }^{653}$ The order sought the immediate suspension of the execution of the requirements imposed by IMCC pending the definitive settlement of the case. ${ }^{654}$ This included the immediate cancellation of any procedure designed to sell the cargo found on board the "Juno Trader"; the immediate lifting of the prohibition on the crew of the "Juno Trader" from the Port of Bissau and the immediate return of their passports; and finally the immediate suspension of the payment of fine required of the captain of the vessel and the non-invocation of the bank guarantee posted to that effect. ${ }^{655}$

The Tribunal found that it had jurisdiction, ${ }^{656}$ the Application was admissible, ${ }^{657}$ and that Guinea-Bissau had violated Article 73(2) of the Convention, and therefore would have to promptly release the Juno Trader along with its crew and cargo. ${ }^{658}$ Embarking on the assessment of a reasonable bond for the release of Juno Trader and its crew, the Tribunal repeated some of its observations from the "Camouco" Case 659 and the "Monte Confurco" Case 660

\footnotetext{
${ }^{650}$ This was contained in Minute No. 14/CIMF/04 of 19 October 2004. The "Juno Trader" Judgment, above n 636, para 43.

${ }^{651}$ The "Juno Trader" Judgment, above n 636, para 43.

${ }^{652}$ The "Juno Trader" Judgment, above n 636, paras 50 and 90.

${ }^{653}$ The "Juno Trader" Judgment, above n 636, para 52.

${ }^{654}$ The "Juno Trader" Judgment, above n 636, para 52.

${ }^{655}$ The "Juno Trader" Judgment, above n 636, para 52.

${ }^{656}$ The "Juno Trader" Judgment, above n 636, paras $55-65$.

${ }^{657}$ The "Juno Trader" Judgment, above n 636, paras 66- 70.

${ }^{658}$ The “Juno Trader" Judgment, above n 636, paras $71-80$.

${ }^{659}$ The "Juno Trader" Judgment, above n 636, para 82.

${ }^{660}$ The “Juno Trader" Judgment, above n 636, paras 83 and 84.
} 
made with regard to the relevant factors for determining a reasonable bond. The Tribunal then launched itself into an explanation of each of the relevant factors and their presence in the current case.

Identifying the first question of the gravity of the alleged offences, the Tribunal specifically took note of the concern expressed by Guinea-Bissau that illegal, unregulated and unreported fishing in its EEZ had seriously depleted its fisheries resources. ${ }^{661}$ The Tribunal further observed that it was possible to evaluate the gravity of the alleged offences by referring to the penalties imposed or imposable under the laws of the detaining state for "the need to avoid disproportion between the gravity of the alleged offences and the amount of the bond." ${ }^{\circ 62}$ ITLOS found the bond sought by Guinea-Bissau to be disproportionate to the gravity of the alleged offences. Sadly, it did not spare any room in its 35page judgment in explaining how the bond it determined to be reasonable was proportionate to the gravity of the offences alleged in this case.

ITLOS merely took note of the fact that the fine imposed on the "Juno Trader" by Guinea-Bissau was not brought under "the 'serious offence' article... [but was] a lighter fine under the 'other offences' rules." ${ }^{\prime 63}$ On the issue of the value of the "Juno Trader", the Tribunal recognised the disparity in the values assigned by the parties to the case - whereas Saint Vincent and the Grenadines pegged its worth at US\$ 460,000, Guinea-Bissau argued that its market value should be nearly double at US\$ 800,000. ${ }^{664}$ ITLOS however did not indicate as to which amount it relied upon in determining a reasonable bond, in case it did in fact take the value of the "Juno Trader" into consideration in its decision. Turning to the value of the cargo, the Tribunal noted the Applicant's claim that the cargo had been worth a total of US\$ 459,938.65 representing the price for which it was sold in advance to a company in Ghana. ${ }^{665}$ ITLOS also went on to acknowledge the Applicant's assertion that the running costs for the "Juno Trader" lying off the Guinea-Bissau for almost 3 months was nearly US\$ 3,600 per day. ${ }^{666}$ But even though it expressly stated its "view that these considerations should be taken into account in determining the amount of a

\footnotetext{
${ }^{661}$ The "Juno Trader” Judgment, above n 636, para 87.

${ }^{662}$ The "Juno Trader" Judgment, above n 636, para 89.

${ }^{663}$ The "Juno Trader" Judgment, above n 636, para 91.

${ }^{664}$ The "Juno Trader" Judgment, above n 636, para 92.

${ }^{665}$ The "Juno Trader" Judgment, above n 636, para 93.

${ }^{666}$ The “Juno Trader” Judgment, above n 636, para 93.
} 
reasonable bond" ${ }^{\$ 67}$, it failed to elucidate the extent to which such factors influenced its judgment in pronouncing a reasonable bond.

Ultimately, the Tribunal unanimously decided that the amount of the bond or other financial security should be EUR 300,000 but, as with its previous prompt release cases, failed to provide any justification for arriving at the particular amount. ${ }^{668}$ ITLOS also held unanimously that the amount of EUR 8,770 , previously paid to Guinea-Bissau, as fine imposed on the captain of the vessel should be considered as a bond along with the EUR 300,000 that was required to be posted in the wake of the judgment. ${ }^{669}$ Therefore, taken in conjunction, it can be concluded that ITLOS had ordered a bond of EUR 308,770 to be reasonable for the prompt release of the "Juno Trader" and its crew. Besides specifying a bond amount that must appear to be inadequately reasoned, the Tribunal reduced the bond as sought by the detaining state by EUR 918,444 signifying a percentage reduction of 74.84 per cent. ${ }^{670}$ ITLOS was however justified in ordering that the bond of EUR 50,000 posted on behalf of the shipowner in the form of a Protection and Indemnity letter of guarantee, which was not deemed to be acceptable to Guinea-Bissau, to be returned to the Applicant on the posting of the bond of EUR 300,000. ${ }^{671}$

It has been publicly declared that countries around the world are "watching the Tribunal's proceedings with a keen eye and an anxious heart."672

\footnotetext{
${ }^{667}$ The “Juno Trader” Judgment, above n 636, para 94.

${ }^{668}$ The "Juno Trader" Judgment, above n 636, para 98.

${ }^{669}$ The "Juno Trader" Judgment, above n 636, para 99.

${ }^{670}$ See TABLE - I of present thesis, 87.

${ }^{671}$ The "Juno Trader" Judgment, above n 636, paras 61 and 99.

${ }^{672}$ Application on behalf of Saint Vincent and the Grenadines “Juno Trader" Case, $<$ http://www.itlos.org/> (last accessed 1 December 2005) para 127. As examples of the close watch on the Tribunal's work, see John E Noyes "The International Tribunal for the Law of the Sea" (1998) 32 Cornell Intl L J 109; Ben Chigara "The International Tribunal for the Law of the Sea and Customary International Law" (2000) 22 Loy L A Intl \& Comp L Rev 433; Bernard Oxman "The International Tribunal for the Law of the Sea" in David D Caron and Harry N Scheiber (eds) Bringing New Law to Ocean Waters (Martinus Nijhoff Publishers, Leiden, 2004) 285; Philippe Sands “ITLOS: An International Lawyer's Perspective" in M H Nordquist and J N Moore (eds) Current Marine Environmental Issues and the International Tribunal for the Law of the Sea (Kluwer Law International, The Hague, 2001) 141; Nick Howe "ITLOS - A Practitioner's Perspective" in M H Nordquist and J N Moore (eds) Current Marine Environmental Issues and the International Tribunal for the Law of the Sea (Kluwer Law International, The Hague, 2001) 159.
} 
The practice of 'discounting' the nature and form of bond, has, to say the least, given rise to apprehension among coastal states as to whether their own demands as to bond amounts would withstand scrutiny by ITLOS. ${ }^{673}$ Particularly in the M/V “Saiga”, “Camouco”, “Monte Confurco", “Grand Prince” and "Volga” Cases, the Tribunal was asked to assess in some detail, the coastal state practices, laws and regulations dealing with illegal fishing and their consistency with the duties prescribed in the Convention's provisions. ${ }^{674}$ As one learned commentator has written, it is "desirable that municipal courts should have some idea of how to set bonds at a level that amounts to a fulfilment, rather than a violation, of those duties. $" 675$ The above requirement is all the more critical in light of the likelihood of increased detention of vessels in various part of the world in recent times. ${ }^{676}$

Despite this practice of turning down the bonds sought by detaining states as "unreasonable" on every possible occasion, ITLOS is far from pointing out in clear terms what constitutes a reasonable bond. It has at best, spelt out some of the factors that are relevant in the assessment of the reasonableness of bonds. ${ }^{677}$ Overall, in the absence of clear directives and guidelines from the international arena, namely ITLOS, coastal states remain unsure of how to go about seeking a bond that would not deemed by ITLOS as unreasonable. On the destructive side: ${ }^{678}$

The lack of precision, caused by the unwillingness of the Tribunal to narrow further the general contours set thus far, could have a negative influence on national judges who might well try to "misuse" the broad framework created by the Tribunal.

Similar is the fate of the factor "penalties imposed or imposable under the laws of the detaining State." Though ITLOS mentions this factor in its judgments, the final bond amounts do not reflect a consideration of this amount. It is curious how the Tribunal takes note of the gravity of the alleged offences and the penalties attaching to them and yet fails to clearly account for them in

\footnotetext{
${ }^{673}$ Serdy and Bliss, above n 488, 273.

674 "Illegal Southern Ocean Fishing and Prompt Release", above n 485, 172.

675 "International Tribunal for the Law of the Sea: Survey for 2000", above n _, 561.

${ }^{676}$ See Gerald A Malia "The New 'International Tribunal for the Law of the Sea': Prospects for Dispute Resolution at the "Sea Court"” (1995) 7 Geo Intl Envtl L Rev 791, 792.

${ }^{677}$ The "Camouco" Judgment, above n 509, para 67.

${ }^{678}$ Erik Franckx "'Reasonable Bond' in the Practice of the International Tribunal for the Law of the Sea" (2002) 32 Cal W Intl L J 303, 338.
} 
the bond it finally determines to be "reasonable". ${ }^{679}$ Of all the individual factors that the Tribunal had invented in the "Camouco" Case and reiterated in subsequent judgments, it seemed to have given credit, and only in a certain measure to the "value of the detained vessel and of the cargo seized" and "the amount of the bond imposed by the detaining State." ${ }^{680}$ It is submitted that coastal states, in the absence of proper guidance as to internationally acceptable bond amounts, are in a situation of uncertainty about an area that constitutes an important element of oceans governance. Fortunately, the Tribunal can clarify this uncertainty to a considerable extent and it is hoped that this will happen in the future as more prompt release disputes are brought before ITLOS, and it develops its jurisprudence more clearly and consistently.

\title{
$7 \quad$ Conclusion
}

It is submitted that the Tribunal's jurisprudence in prompt release cases leaves much to be desired. Chief among some of these desirable elements is the need for the Tribunal to provide more reasoned and articulate judgments that adequately justify the prescription of "reasonable bonds." ${ }^{\text {,61 }}$ As Vaughan Lowe writes with a dash of sarcasm: ${ }^{682}$

\begin{abstract}
One does not expect a shopping list, in which the Tribunal says it adds $x$ thousand dollars for this factor and $y$ thousand for that. It would, however, be of some help to national courts if the Tribunal were to explain the kind of reasoning that should in its view precede the determination of the level and form of a reasonable bond.
\end{abstract}

It is not clear why the Tribunal has not sufficiently provided its reasons for favouring a certain bond amount over any other. However, one of the judges of the Tribunal, David Anderson, has addressed generally some of reasons for the brevity in the Tribunal's judgments. ${ }^{683}$ Nevertheless, whatever the collective logic of the Tribunal that deters it from providing adequately reasoned decisions,

\footnotetext{
${ }^{679}$ See The "Volga” Judgment, above n 579, para 69.

${ }^{680}$ The "Camouco" Judgment, above n 509, para 67.

681 See generally Edward Arthur Laing "ITLOS Procedures and Practices: Bonds" in M H Nordquist and J N Moore (eds) Current Marine Environmental Issues and the International Tribunal for the Law of the Sea (Kluwer Law International, The Hague, 2001) 113, 114.

682 "International Tribunal for the Law of the Sea: Survey for 2000", above n 529, 566.

683 "Deliberations, Judgments, and Separate Opinions in the Practice of the International Tribunal for the Law of the Sea", above n 536, 68 .
} 
it must bear in mind that absence of justified reasons even in interlocutory matters such as prompt release cases invites unwarranted consequences, which could otherwise be avoided. In this regard, it is worthwhile to quote Judge Park from his Separate Opinion in the "Juno Trader" Case: ${ }^{684}$

\begin{abstract}
[O]nce made public, the decisions of the Tribunal $\ldots$ are subjected to intensive public scrutiny by professional and other commentators. It would be thus incumbent on the Tribunal and on the parties to disputes as well to be dutifully precautious to leave no stone unturned and no turn unstoned in their deliberations, if for no other reason than to do justice to the saying that the language of law is intended not only to be understood but also not to be misunderstood.
\end{abstract}

The Tribunal would also serve the cause of environmental oceans governance better if it were to really take into account the concerns of coastal states in the determination of a reasonable bond. As has been recommended elsewhere, the real interests of coastal states in protecting their marine living resources needs to be recognised in the balancing process undertaken by ITLOS. ${ }^{685}$ ITLOS can serve the cause of good oceans governance by bringing in more clarity and consistency in its judgments. This will eliminate the possibility of further conflict to a considerable extent. It would greatly benefit coastal states if ITLOS were to include an account in its judgments of the degree to which the individual factors weighed in the process determination of a reasonable bond in prompt release cases.

However, the Tribunal has been expending considerable resources in trying to improve the understanding of what would be a "reasonable bond." The 2004 Annual Report of the Tribunal reveals that the Committee on Rules and Judicial Practice of ITLOS considered a document presented by the ITLOS Registry on the practice in different states concerning the amount of bonds posted for maritime law infringement in areas under national jurisdiction. ${ }^{686}$ It is clear that the Tribunal is interested in being well informed about national

\footnotetext{
${ }^{684}$ The “Juno Trader" - Judge Park, above n 29, para 15.

${ }^{685}$ Donald R Rothwell and Tim Stephens "Dispute Resolution and the Law of the Sea: Reconciling the Interaction Between the LOS Convention and Other Environmental Instruments" in Alex G Oude Elferink and Donald R Rothwell (eds) Oceans Management in the 21st Century: Institutional Frameworks and Responses (Martinus Nijhoff Publishers, Leiden, 2004) 209, 217.

${ }^{686}$ ITLOS Annual Report 2004, above n 32,para 44.
} 
developments in this area, as it requested the Registry to keep updating the information in the document on a regular basis. ${ }^{687}$

\section{B Proceeds of the Catch in the Reasonableness of Bond}

The issue of the proceeds of catch before the Tribunal has been deemed to be "one of the most controversial in its prompt release jurisprudence." "688 As noted before, in the "Monte Confurco" Case, ITLOS had clearly considered that the value of the fish caught was a relevant factor in the assessment of a reasonable bond and therefore 9,000,000 French franc worth of Patagonian toothfish had formed a part of the bond finally prescribed. ${ }^{689}$ Judge Jesus in his dissenting opinion in the same case had opined - "the majority decision was unwise to have taken the value of the fish seized as part of the bond, when the domestic legislation makes it subject to confiscation."690

Surprisingly, in the "Volga" Case, ITLOS has by implication overruled its own precedent ${ }^{691}$ by ruling that "[a]lthough the proceeds of ... the catch represent a guarantee to [Australia], they have no relevance to the bond to be set for the release of the vessel and the members of the crew." ${ }^{\circ 92}$ It appears that the Tribunal was impressed with Australia's argument that allowing the proceeds of the catch to be a part of the bond would be similar to allowing a burglar to put up the stolen goods as security for bail. ${ }^{693}$ However, Judge ad hoc Shearer opined that the Tribunal did not depart from its previous decisions in holding that the proceeds of the catch held in trust by Australia were to be regarded as overall security. $^{694}$

The doctrine of precedent or stare decisis does not strictly apply in international law. ${ }^{695}$ However, at a time such as this where the proliferation of

\footnotetext{
${ }^{687}$ ITLOS Annual Report 2004, above n 32,para 45.

688 "Law of the Sea: An Article 292 Bond", above n 610, 291.

${ }^{689}$ The "Monte Confurco" Judgment, above n 482, paras 86 and 93.

${ }^{690}$ The "Monte Confurco" - Judge Jesus dissenting, above n 577, para 32.

691 "Law of the Sea: An Article 292 Bond", above n 610, 291.

692 The "Volga" Judgment, above n 579, para 86.

693 The "Volga" Case, statement by James Crawford at Public sitting, ITLOS/PV 02/02 12 December 2002 pm, 22 <http://www.itlos.org/> (last accessed 1 December 2005).

${ }^{694}$ The "Volga" - Shearer dissenting, above n 623, para 15.

${ }^{695}$ See Shabtai Rosenne The Law and Practice of the International Court (vol 2, A W Sijthoff, Leyden, 1965) 612; Boleslaw A Boczek International Law: A Dictionary (Scarecrow Press, Lanham (Maryland), 2005) xxii.
} 
international courts and tribunals is feared to lead to the fragmentation of international law, ${ }^{696}$ the least international judicial bodies can be expected to do is to develop a consistent and dependable jurisprudence within the cases before it. The failure of the Tribunal to maintain consistency in its prompt release jurisprudence cannot be seen as a beneficial factor for good oceans governance.

\section{Illegal, Unreported and Unregulated Fishing and Prompt Release Procedures}

IUU fishing is a major problem facing fisheries in many parts of the world and has been argued to be one of the most complex issues of oceans governance. ${ }^{697}$ The Patagonian toothfish (Dissostichus eleginoides), typically found in the frigid waters of the Southern Ocean became a victim of IUU fishing soon after its discovery by Soviet Union fishing fleets in $1985 .{ }^{698}$ Vessels engaging in IUU fishing are more often than not fly flags of convenience ${ }^{699}$ or

\footnotetext{
${ }^{696}$ See Tullio Treves "Judicial Lawmaking in an Era of 'Proliferation' of International Courts and Tribunals: Development or Fragmentation of International Law?" in Rüdiger Wolfrum and Volker Röben (eds) Developments of International Law in Treaty Making (Springer, Berlin, 2005) 587.

${ }^{697}$ Fridtjof Nansen Institute "An Acute Issue in Ocean Governance" (2003) 1 Nansen News, available at $<$ http://www.fni.no/nanew/NN1-03-web.pdf $>$ (last accessed 26 November 2005). For a discussion on the problem, see Food and Agriculture Organisation Stopping Illegal, Unreported and Unregulated Fishing (FAO, Rome, 2002). For legal, economic and historical factors aiding the growth of IUU fishing, see Rachel Baird "Illegal, Unreported and Unregulated Fishing: An Analysis of the Legal, Economic and Historical Factors Relevant to its Development and Persistence" (2004) 5 Melb J Intl L 299.

${ }^{698}$ Liza D Fallon and Lorne K Kriwoken "International Influence of an Australian Nongovernment Organization in the Protection of Patagonian Toothfish" (2004) 35 ODIL 221, 222. For a history of the IUU fishing for the Patagonian Toothfish and CCAMLR measures taken to combat it, see D J Agnew "The Illegal and Unregulated Fishery for Toothfish in the Southern Ocean, and the CCAMLR Catch Documentation Scheme" (2000) 24 Marine Policy 361. Specifically on IUU fishers in the Southern Ocean, see Coalition of Legal Toothfish Operators "The Alphabet Boats: A Case Study of Toothfish Poaching in the Southern Ocean" available at $<\mathrm{http} / / / \mathrm{www}$.colto.org/PDFs/Alphabet_Soup.pdf> (last accessed 26 October 2005); Coalition of Legal Toothfish Operators "Rogues Gallery: The New Face of IUU Fishing for Toothfish" (2003) available at $<$ http://www.colto.org/PDFs/RoguesGallery.pdf $>$ (last accessed 26 October 2005). To read more about the Patagonian toothfish and its current endangered state, see National Environmental Trust Destined for Extinction: The Fate of Chilean Sea Bass (National Environmental Trust, Washington DC, 2001) available at $<$ http://www.net.org/relatives/4300.pdf $>$ (last accessed 28 October 2005); National Environmental Trust Black Market for White Gold: The Illegal Trade in Chilean Sea Bass (National Environmental Trust, Washington DC, 2004) available at $<$ http://www.net.org/reports/csb_report.pdf $>$ (last accessed 4 August 2005).

${ }^{699}$ For a detailed definition of flags of convenience, also sometimes called the flags of open registries and their history, see H Edwin Anderson III "The Nationality of Ships and Flags of Convenience: Economics, Politics, and Alternatives" (1996) 21 Tul Mar L J 139, 156.
} 
are reflagged vessels ${ }^{700}$ or even stateless vessels. ${ }^{701}$ The "Camouco", "Monte Confurco", "Grand Prince” and "Volga” Cases before ITLOS, raised the issue of IUU fishing. It is also noted that the prompt release cases brought before the Tribunal to date have involved vessels that "have been reflagged one or more times and ships flying a flag belonging to a State that has modest connections with the ship." 702 Satya Nandan, the Secretary-General of ISA has commented, "[it] is a matter of great concern that seven out of the 11 cases before the Tribunal related to the activities of fishing vessels flying flags of convenience." 703

In this regard, the New Zealand Diplomatic Note of 6 December 2002 appended to the Australian Statement in Response in the "Volga" Case makes a strong point worthy of reiteration here: ${ }^{704}$

[T] he Tribunal ought to be cognisant of the serious and growing problem of IUU fishing ... in these waters, a result of enforcement difficulties and the very high value of the fishery. These factors mean that the incentive for vessel owners and operators to engage in IUU fishing is significant. ... Coastal States, and States Parties to [the LOSC] and regional fisheries management organizations, including CCAMLR, must take steps to compel and encourage better observance with the provision of these instruments. It is clear that the Tribunal also has a role to play.

As one of the 'implementing agreements' of the LOSC, the Fish Stocks Agreement provides that "[s]anctions applicable in respect of violations shall be adequate in severity to be effective in securing compliance and to discourage violations wherever they occur and shall deprive offenders of the benefits accruing from their illegal activities." 705 The language of the law is quite clear on this point and stresses the need for sanctions against violations of fisheries laws to be a deterrent against future violations. In this light, appeals made before the Tribunal to take the IUU problem into consideration in the determination of a reasonable bond appear justified. It is noteworthy that heavy deterrent fines and

\footnotetext{
${ }^{700}$ See Jessica K Ferrell "Controlling Flags of Convenience: One Measure to Stop Overfishing of Collapsing Fish Stocks" (2005) 35 Envtl L 323; "Flags of Convenience Before the Law of the Sea Tribunal", above n 609, 179.

${ }^{701}$ See generally Ted L McDorman "Stateless Fishing Vessels, International Law and the UN High Seas Fisheries Conference” (1994) 25 (4) J Mar L \& Com 531.

702 "Flags of Convenience Before the Law of the Sea Tribunal", above n 609, 180.

703 "Multilateral Oceans Governance and the International Seabed Authority", above n 199, 302.

704 The "Volga" Case, statement by W M Campbell at Public sitting, ITLOS/PV 02/02 12 December 2002 pm, 7, available at <http://www.itlos.org/> (last accessed 1 December 2005).

${ }^{705}$ Fish Stocks Agreement, above n 196, art 19(2).
} 
bonds have been reported to have a significant impact upon IUU vessels with many companies facing such punitive measures are now reluctant to run the risk of future arrest and hence turning to lawful activities. ${ }^{706}$

IUU fishing ${ }^{707}$ is an activity driven by economic factors; ${ }^{708}$ if the benefits accruing from the business are higher than the costs involved in carrying it out, the practice thrives. ${ }^{709}$ IUU fishing is a dangerous activity that not only adversely affects fish stocks, but is also accompanied by poor vessel standards and poor working conditions for deckhands involved. ${ }^{710}$ Given all the negative implications of IUU fishing and a certain preference of vessels indulging in such nefarious activities to bring prompt release applications before the Tribunal, only to be let off on conveniently "discounted" bonds, ITLOS is in effect poised to become an "unwitting accomplice to criminal activity." 711 The "discounting" of bonds at the hands of ITLOS has significant implications for the enforcement of regional Conventions such as CCAMLR. ${ }^{712}$ This is because if ITLOS continues to narrowly interpret the Convention's provisions, it would lead to coastal states being unable to impose a heavy penalty and illegal fishers who have little or no connection with the flag state would rather forfeit the bond rather than face charges on vessel release. ${ }^{713}$ This danger seems to be particularly acute in

\footnotetext{
${ }^{706}$ Agnew, above n 698, 366. Diane Erceg "Deterring IUU Fishing through State Control over Nationals" (2006) 30 Marine Policy 173, 176.

${ }^{707}$ For a good collection of 28 articles discussing the many aspects and drivers of IUU fishing, see OECD Fish Piracy: Combating Illegal, Unreported and Unregulated Fishing (OECD, Paris, 2004).

${ }^{708}$ See Betrand Le Gallic and Anthony Cox "An Economic Analysis of Illegal, Unreported and Unregulated (IUU) Fishing: Key Drivers and Possible Solutions" Marine Policy (Article in Press).

${ }^{709}$ Carl-Christian Schmidt "Economic Drivers of Illegal, Unreported and Unregulated (IUU) Fishing" (2005) 20 (2-3) IJMCL 479, 482. See also Davor Vidas "IUU Fishing or IUU Operations? Some Observations on Diagnosis and Current Treatment" in David D Caron and Harry N Scheiber (eds) Bringing New Law to Ocean Waters (Martinus Nijhoff Publishers, Leiden, 2004) 125.

${ }^{710}$ Schmidt, above $\mathrm{n} 709,282$. For an informative report on detrimental effects of IUU fishing, see Environmental Justice Foundation Pirates \& Profiteers: How Pirate Fishing Fleets are Robbing People and Oceans (Environmental Justice Foundation, London, 2005) available at $<\mathrm{http} / / /$ www.ejfoundation.org/pdfs/pirates_and_profiteers.pdf $>$ (last accessed 18 October 2005).

${ }^{711}$ The "Volga" Case, statement by James Crawford at Public sitting, ITLOS/PV 02/02 12 December 2002 pm, 18, available at <http://www.itlos.org/> (last accessed 1 December 2005).

${ }^{712}$ Laura Little and Marcos A Orellana "Can CITES Play a Role in Solving the Problem of IUU Fishing?: The Trouble with Patagonian Toothfish" (2004) Yearbook Colo J Envtl L \& Poly 21, 58.

${ }^{713}$ Little and Orellana, above n 712, 56.
} 
connection with Patagonian toothfish as they have a high market value and the value of its catch could easily outweigh a significantly low bond amount. ${ }^{714}$

It seems to this author that unless the Tribunal is able to send a clear message to the IUU operators that it will not stand to be used as a tool to get them easily out of trouble in the course of their illegal business, IUU prevention endeavours at global and regional levels ${ }^{715}$ will continue to be undermined. It can be recommended that ITLOS should bear in mind the nature of the alleged offences in prompt release cases. In addition, where the evidence clearly points towards alleged IUU fishing activities, ITLOS should in support of coastal states' endeavours refrain from "discounting" the bonds sought.

\section{Conclusions}

Summing up this part on prompt release cases, it can be reiterated that the Tribunal's practice of "discounting" bonds can have destructive impact on oceans governance. This part has revealed that the practice of "discounting" bonds is leading to uncertainty among coastal states as to the nature of a "reasonable" bond, and arguably encouraging IUU fishing indirectly in some measure. Inconsistencies have also been noticed in the Tribunal's prompt release jurisprudence, especially with regard to the consideration of the proceeds of the catch in the reasonableness of bonds.

\section{PROVISIONAL MEASURES CASES AND SUBSEQUENT JUDICIAL PROCEEDINGS}

This part shall be devoted to analysing the provisional measures cases invoked under Part XV of the LOSC, and the subsequent judicial proceedings undertaken towards the final settlement of the disputes. Just like the previous part

\footnotetext{
${ }^{714}$ Little and Orellana, above n 712, 57.

715 See Moritaka Hayashi "Illegal, Unreported, and Unregulated (IUU) Fishing: Global and Regional Responses" in David D Caron and Harry N Scheiber (eds) Bringing New Law to Ocean Waters (Martinus Nijhoff Publishers, Leiden, 2004) 95. See also Erik Jaap Molenaar "Regional Fisheries Management Organizations: issues of Participation, Allocation and Unregulated Fishing" in Alex G Oude Elferink and Donald R Rothwell (eds) Oceans Management in the 21st Century: Institutional Frameworks and Responses (Martinus Nijhoff Publishers, Leiden, 2004) 69.
} 
on prompt release cases, the aim of this part is to bring out those elements of the jurisprudence in this area, which have contributed to oceans governance.

Under Article 290 of the LOSC, a dispute settlement body empowered under the Convention may provide provisional measures in a dispute referred to it, in order to preserve the respective rights of the parties to the dispute or to prevent serious harm to the marine environment. ${ }^{716}$ If a dispute is to be submitted to an arbitration tribunal, pending its constitution, parties to the dispute may agree to refer the dispute to any court or tribunal. ${ }^{717}$ Failing such agreement within two weeks from the request for provisional measures, ITLOS or, with respect to activities in the Area, SDC has residual jurisdiction to prescribe, modify or revoke provisional measures under Article 290(5) of the Convention. $^{718}$ However, ITLOS or SDC can only prescribe provisional measures if it considers that prima facie the arbitral tribunal, which is to be constituted, would have jurisdiction in the case and the urgency of the case so demands. ${ }^{719}$ Judge Tafsir Ndaiye has commented that "[u]rgency encompasses procedural and substantive aspects" 720 and "constitutes, together with irreparable harm, the two fundamental elements for the prescription of provisional measures.",721

Shabtai Rosenne has remarked that Article 290(5) marked a major innovation in international law, where a standing international tribunal was granted compulsory jurisdiction to prescribe provisional measures of protection while the arbitral tribunal, to which the principal dispute was to be submitted, was being constituted. ${ }^{722}$ One of the distinguished Judges of the Tribunal, Edward Laing has written that there are at least two main purposes for including

\footnotetext{
${ }^{716}$ LOSC, art 290(1).

${ }^{717}$ LOSC, art 290(5).

${ }^{718}$ LOSC, art 290(5). For some good discussions, see Rüdiger Wolfrum "Provisional Measures of the International Tribunal for the Law of the Sea" in P Chandrasekhara Rao and Rahmatullah Khan (eds) International Tribunal for the Law of the Sea: Law and Practice (Kluwer Law International, The Hague, 2001) 173; Thomas A Mensah "Provisional Measures in the International Tribunal for the Law of the Sea (ITLOS)" (2002) 62 (1-2) ZaöRV 43.

${ }^{719}$ LOSC, art 290(5).

${ }^{720}$ Tafsir Malick Ndiaye "Provisional Measures before the International Tribunal for the Law of the Sea" in M H Nordquist and J N Moore (eds) Current Marine Environmental Issues and the International Tribunal for the Law of the Sea (Kluwer Law International, The Hague, 2001) 95, 98.

${ }^{721}$ Ndiaye, above $\mathrm{n} 720,99$.

${ }^{722}$ Shabtai Rosenne Provisional Measures in International Law: The International Court of Justice and the International Tribunal for the Law of the Sea (Oxford University Press, Oxford, 2005) 49 [Provisional Measure in International Law].
} 
provisional measures clauses in treaties - either "the accommodation of requests by one party for the preservation of the 'status quo pending the final decision', or ... the maintenance of international peace and good order." ${ }^{, 723}$ Rosenne explains further: ${ }^{724}$

Provisional measures in international litigation have as their essential purpose to prevent any unilateral action by one party from frustrating a possible decision in favour of the other party, and are closely related to the basic principle of international litigation, that the consent ad litem of all parties to the dispute is essential before any international court or tribunal can act.

To date, this residual jurisdiction of the Tribunal under Article 290(5) has been invoked in four cases. These four cases in which ITLOS has passed Orders for provisional measures are - M/V "Saiga" (No 2) Case, ${ }^{725}$ Southern Bluefin Tuna Cases, ${ }^{726}$ MOX Plant Case ${ }^{727}$, and Case Concerning Land Reclamation by Singapore In and Around the Straits of Johor. ${ }^{728}$ The Orders in all these cases except one were followed by the composition of the arbitral tribunals under Annex VII to which the principal disputes were submitted. The exception relates to the dispute concerning the $M / V$ "Saiga", the future arbitration proceedings of which were transferred to ITLOS by agreement between the disputant Parties.

Provisional measures jurisprudence under the Convention and subsequent judicial proceedings have often been controversial, and have invited criticisms from commentators. The ones that are beyond the scope of the present thesis are not discussed here, though references have been provided at necessary places to guide the reader to relevant commentaries. In the following paragraphs, the Tribunal's jurisprudence in the above cases is discussed and analysed in the belief that they have had a notable impact on oceans governance. At the same

\footnotetext{
${ }^{723}$ Edward A Laing "A Perspective on Provisional Measures under UNCLOS" (1998) 29 NYIL 45, 47 (footnotes omitted).

${ }^{724}$ Provisional Measure in International Law, above n 722, 132.

${ }^{725}$ The M/V "Saiga" (No 2) Case (Saint Vincent and the Grenadines $v$ Guinea) (Provisional Measures) [1998] <http://www.itlos.org/> (last accessed 1 December 2005) Judgment of the majority [The M/V "Saiga" (No 2) - Provisional Measures].

726 Southern Bluefin Tuna Cases (New Zealand v Japan; Australia v Japan) (Provisional Measures) [1999] <http://www.itlos.org/> (last accessed 1 December 2005) Judgment of the majority [Southern Bluefin Tuna Cases - Provisional Measures].

${ }^{727}$ The MOX Plant Case (Ireland v United Kingdom) (Provisional Measures) [2001] $<$ http://www.itlos.org/> (last accessed 1 December 2005) Judgment of the majority [The MOX Plant Case - Provisional Measures].

${ }^{728}$ Case Concerning Land Reclamation by Singapore In and Around the Straits of Johor (Malaysia v Singapore) (Provisional Measures) [2003] <http://www.itlos.org/> (last accessed 1 December 2005) Judgment of the majority [Land Reclamation Case - Provisional Measures].
} 
time, the jurisprudence of the arbitral tribunals constituted following the prescription of provisional measures by ITLOS is also assessed in the light of their principal impacts on oceans governance. ITLOS's judgment on the merits of the $M / V$ "Saiga" (No. 2) Case is also analysed in the same light. It is shown that the developments in this area of dispute settlement in the law of the sea have contributed much to good oceans governance by interpreting and clarifying the law, maintaining peace and security in ocean space, and facilitating co-operation among states.

\section{A The M/V “Saiga”(No. 2) Case (Provisional Measures)}

As seen previously, on 4 December 1997 the Tribunal had ordered the prompt release of the $\mathrm{M} / \mathrm{V}$ "Saiga" and its crew from Guinean detention and custody on the posting of \$ US 400,000. ${ }^{729}$ However, though Saint Vincent and the Grenadines had posted the prescribed bond with Guinea on 10 December 1997 in accordance with the Tribunal's judgment, Guinea had refused to promptly release the vessel and its crew. ${ }^{730}$ Therefore, on 22 December 1997, Saint Vincent and the Grenadines submitted a notification to Guinea instituting proceedings in accordance with Annex VII for the establishment of an arbitral tribunal with regard to settling their continuing dispute involving the $M / V$ "Saiga". ${ }^{731}$ The M/V "Saiga" (No. 2) Case appeared on the Tribunal's docket on 13 January 1998, 40 days after the Tribunal's judgment in The M/ V "Saiga" Case. $^{732}$ Thus, like the Tribunal's prompt release jurisprudence, Saint Vincent and the Grenadines and Guinea inaugurated the Tribunal's provisional measures jurisprudence with their dispute centring on the $M / V$ "Saiga."

A significant development that took place in little over a month after the request for provisional measures was made deserves to be pointed out. Saint Vincent and the Grenadines and Guinea, still embroiled in their bilateral dispute, decided to transfer to ITLOS the arbitration proceedings that Saint Vincent and the Grenadines had instituted by its notification of 22 December $1997 .{ }^{733}$ What is

\footnotetext{
${ }^{729}$ The $M / V$ "Saiga” Judgment, above n 487, para 86(3).

${ }^{730}$ The M/V "Saiga” (No 2) - Provisional Measures, above n 725, para 3.

${ }^{731}$ The $M / V$ "Saiga” (No 2) - Provisional Measures, above n 725, para 20(4).

${ }^{732}$ The M/V "Saiga” (No 2) - Provisional Measures, above n 725, para 3.

${ }^{733}$ The M/V “Saiga” (No 2) - Provisional Measures, above n 725, para 12.
} 
remarkable about this development is that this was a result of the then recent exchanges of views between the two Governments, a significant portion of which was facilitated through the good offices of the President of ITLOS. ${ }^{734}$ Therefore, it can be seen that ITLOS, represented by its President, was instrumental at the outset in helping the two disputant states in finding common ground on which to resolve their differences.

After the Tribunal's prompt release judgment in the dispute, not only had Guinea refused to release the $M / V$ "Saiga", but "[c]riminal proceedings were brought against the master who received a heavy sentence and a heavy fine, and the vessel was held as security." "735 With such conditions aggravating the dispute, Saint Vincent and the Grenadines was forced to bring the request for provisional measures before ITLOS. ${ }^{736}$ Guinea on its part was adamant that in the circumstances, it "[did] not accept any other settlement procedure than the Guinean Courts." ${ }^{737}$ Further to Saint Vincent and the Grenadines's request that Guinean authorities cease and desist from interfering with the rights of navigation of Vincentian vessels, ${ }^{738}$ Guinea responded that it would not give such "carte blanche" by giving a general undertaking. Instead, Guinea argued that any order to cease arresting vessels would be a decision on the merits, and that instead, Saint Vincent and the Grenadines should instruct its vessels to avoid the Guinean EEZ. ${ }^{740}$

Faced with such arguments, on 11 March 1998, ITLOS "prescribed" provisional measures inter alia, ordering Guinea to refrain from taking any judicial or administrative measure against the $M / V$ "Saiga" or any entity connected to it. ${ }^{741}$ It also "recommended" that the Parties: ${ }^{742}$

\footnotetext{
${ }^{734}$ This was acknowledged in the 'Agreement by Exchange of Letters' of 20 February 1998 between the parties that transferred the arbitral proceedings to ITLOS. See The M/V "Saiga" (No 2) - Provisional Measures, above n 725, para 14.

${ }^{735}$ Shabtai Rosenne "International Tribunal for the Law of the Sea: 1998 Survey" (1999) 14 (4) IJMCL 453, 459.

${ }^{736}$ Statement of Mr Karl Joseph, Counsel for the Saint Vincent and the Grenadines, Minutes of the Public Sittings held from $23-24$ February 1998, available at $<$ http://www.itlos.org/> (last accessed 1 December 2005), 12.

${ }^{737}$ The M/V "Saiga” (No 2) - Provisional Measures, above n 725, para 22.

${ }^{738}$ The M/V "Saiga" (No 2) - Provisional Measures, above n 725, para 21.

${ }^{739}$ The M/V "Saiga" (No 2) - Provisional Measures, above n 725, para 22.

${ }^{740}$ Louise de La Fayette "ITLOS and the Saga of the Saiga: Peaceful Settlement of a Law of the Sea Dispute" (2000) 15 (3) IJMCL 355, 360 ["ITLOS and the Saga of the Saiga"].

${ }^{741}$ The M/V "Saiga" (No 2) - Provisional Measures, above n 725, para 52(1).
} 
... endeavour to find an arrangement to be applied pending the final decision, and to this end the two States should ensure that no action is taken by their respective authorities or vessels flying their flag which might aggravate or extend the dispute submitted to the Tribunal.

Since the $M / V$ "Saiga" was released from detention by Guinea before the Order for provisional measures was made, ITLOS did not need to prescribe provisional measures for its release. ${ }^{743}$

It can be argued that in selectively "prescribing" and "recommending" the above provisional measures, ITLOS went a long way in encouraging peace and harmony between the two states in dispute. One commentator has suggested that the recommendation was made "in an effort to satisfy both parties and to induce them to co-operate ... by in effect ordering the two parties to negotiate a compromise solution." ${ }^{\text {744 }}$ Therefore, in promoting co-operation and mutual respect between the two states, ITLOS aided greatly in the management of the dispute and has been praised justifiably. ${ }^{745}$ This in turn played a significant part in preventing the dispute from escalating into breaches of peace, at least within the span of 16 months until the Tribunal passed a judgment on the merits of the case. Indirectly, the Tribunal's provisional measures were instrumental in maintaining peace and security in the oceans and thus played a constructive role in oceans governance.

\section{B The M/V “Saiga”(No. 2) Case (Merits)}

Saint Vincent and the Grenadines and Guinea returned to face each other at ITLOS in the merits phase of the $M / V$ "Saiga" (No 2) Case, in accordance with their 'Agreement by Exchange of Letters' of 20 February $1998 .{ }^{746}$ From 8 to 20 March 1999, 18 public sittings were held at ITLOS during which Counsels

\footnotetext{
${ }^{742}$ The M/V "Saiga” (No 2) - Provisional Measures, above n 725, para 52(2).

${ }^{743}$ The M/V "Saiga” (No 2) - Provisional Measures, above n 725, para 36.

744 "ITLOS and the Saga of the Saiga", above n 740, 360.

745 See generally Barbara Kwaitkowska "The Saint Vincent and the Grenadines v Guinea M/V Saiga Cases" (1998) 11 LJIL 547, 560 - 562; Barbara Kwaitkowska "Inauguration of the ITLOS Jurisprudence: The Saint Vincent and the Grenadines v. Guinea M/V Saiga Cases" (1999) 30 ODIL 43, $64-69$.

${ }^{746}$ The M/V "Saiga” (No 2) Case (Saint Vincent and the Grenadines v Guinea) (Merits) [1999] $<$ http://www.itlos.org/> (last accessed 1 December 2005) Judgment of the majority [The $M / V$ "Saiga" (No 2) - Merits].
} 
for the disputant States argued at length about a range of issues. ${ }^{747}$ As is expected of an international judgment on merits, there were many issues that the Tribunal dealt with in its 54-page judgment and several of these have been reported and analysed by authors of repute. ${ }^{74}$ For the purposes of the present thesis, three aspects of the judgment are briefly commented upon, since they have long-term beneficial implications for oceans governance. These are - (i) clarification that coastal states did not have customs jurisdiction in the EEZ, ${ }^{749}$ (ii) confirmation of the law on hot pursuit, and (iii) settlement of the law on use of force in the arrest of foreign vessels.

\section{Customs law enforcement in the EEZ}

Saint Vincent and the Grenadines had contended that Guinea was not entitled to enforce its customs laws in its EEZ, since the exercise of such powers goes beyond the provisions of the Convention. ${ }^{750}$ Therefore the arrest of the vessel was illegal and had violated Saint Vincent and the Grenadines's rights. To rebut this, Guinea argued that the application of its customs and contraband laws in the EEZ was not contrary to the Convention and further, that the unauthorised sale of gas oil to fishing vessels was not related to the freedom of navigation under the LOSC as claimed by Saint Vincent and the Grenadines. ${ }^{751}$

The Tribunal delved into this issue by first identifying the provisions of the Convention that did permit the application of customs laws and regulations in the territorial sea ${ }^{752}$ and the contiguous zone. ${ }^{753}$ It also declared that the only circumstances in which the Convention permitted the application of customs

\footnotetext{
${ }^{747}$ The M/V “Saiga” (No 2) - Merits, above n 746, para 21.

748 See Gudmundur Eiriksson International Tribunal for the Law of the Sea (Kluwer Law International, The Hague, 2000) 297 - 309; Barbara Kwaitkowska "The Saint Vincent and the Grenadines v. Guinea M/V Saiga Cases before the International Tribunal for the Law of the Sea" in Donald R Rothwell and Sam Bateman (eds) Navigational Rights and Freedoms and the New Law of the Sea (Kluwer Law International, The Hague, 2000) 275; Roger O' Keefe "ITLOS Flags its Intent" (2000) 59 (3) CLJ 428;

749 "ITLOS and the Saga of the Saiga", above n 740, 392. See Anatoly L Kolodkin "National Legislation in the Light of UNCLOS and the Practice of the International Tribunal for the Law of the Sea" in M H Nordquist and J N Moore (eds) Current Marine Environmental Issues and the International Tribunal for the Law of the Sea (Kluwer Law International, The Hague, 2001) 239.

${ }^{750}$ The $M / V$ "Saiga" (No 2) - Merits, above n 746, para 123.

${ }^{751}$ The M/V "Saiga" (No 2) - Merits, above n 746, para 124.

${ }^{752}$ LOSC, arts 2 and 21.

${ }^{753}$ LOSC, art 33(1). The M/V “Saiga” (No 2) - Merits, above n 746, para 127.
} 
laws in the EEZ was in respect of artificial islands, installations and structures. ${ }^{754}$ Guinea had pleaded that, as a developing country, it suffered considerable fiscal losses from illegal offshore bunkering in its EEZ and therefore under the customary international law principle of public interest, it was entitled to enforce its customs laws in its EEZ. ${ }^{755}$ ITLOS then went further to consider whether Guinea was justified in extending its customs laws to the EEZ under general international law. ${ }^{756}$ However, it found that under the given circumstances, Guinea's customs law enforcement in the EEZ could not be justified and therefore was contrary to the Convention. ${ }^{757}$ It therefore concluded that the arrest and detention of the $M / V$ "Saiga" was therefore illegal and contrary to the Convention and Guinea violated Saint Vincent and the Grenadines's rights under the Convention. ${ }^{758}$

In deciding that coastal states did not enjoy customs jurisdiction in the EEZ, the Tribunal clarified the law and set an important precedent in the law of the sea, and thus served ends of good oceans governance.

\section{$2 \quad$ Hot pursuit}

Saint Vincent and the Grenadines alleged that in arresting the $M / V$ "Saiga" Guinea did not lawfully exercise the right of hot pursuit under Article 111 of the Convention. ${ }^{759}$ Guinea denied that the pursuit was vitiated by any irregularity and maintained that its officers had complied with the requirements set out in Article 111 of the LOSC. ${ }^{760}$ The Tribunal recalled the factual details of the arrest and applied it to the provisions under Article 111 of the Convention. ${ }^{761}$ It then went on to find: ${ }^{762}$

... that the conditions for the exercise of the right of hot pursuit under article 111 of the Convention are cumulative; each of them has to be satisfied for the pursuit to be legitimate ... [and in] this case several of these conditions were not fulfilled.

\footnotetext{
${ }^{754}$ LOSC, art 60(2). The M/V “Saiga” (No 2) - Merits, above n 746, para 127.

${ }^{755}$ The $M / V$ "Saiga” (No 2) - Merits, above n 746, para 130.

${ }^{756}$ The $M / V$ "Saiga” (No 2) - Merits, above n 746, paras 132 - 134.

${ }^{757}$ The M/V "Saiga" (No 2) - Merits, above n 746, paras 135 and 136.

${ }^{758}$ The $M / V$ "Saiga" (No 2) - Merits, above n 746, 136 and 183(7).

${ }^{759}$ The M/V "Saiga” (No 2) - Merits, above n 746, para 139.

${ }^{760}$ The M/V "Saiga” (No 2) - Merits, above n 746, para 142.

${ }^{761}$ The $M / V$ "Saiga” (No 2) - Merits, above n 746, paras 143 - 145.

${ }^{762}$ The M/V "Saiga” (No 2) - Merits, above n 746, para 146.
} 
ITLOS ultimately decided that in arresting the $M / V$ "Saiga", Guinea had contravened the provisions of the Convention on the right of hot pursuit and in doing so, had violated the rights of Saint Vincent and the Grenadines. ${ }^{763}$ The Tribunal, in correctly applying the Convention's provisions on hot pursuit, has given them judicial confirmation. In doing so, ITLOS advanced the cause of good oceans governance not just for the present but for the years to come when its findings will be cited in future disputes involving hot pursuit.

\section{Use of force}

Saint Vincent and the Grenadines also claimed that Guinea had used excessive and unreasonable force in the arrest of the M/V "Saiga". ${ }^{764}$ Guinea denied that any force used in the boarding, stopping or arresting the vessel was either excessive or unreasonable. ${ }^{765}$ The Tribunal went on to clarify the principles of law enforcement at sea and used both international case law as well as treaty law to assert that "all efforts should be made to ensure that life is not endangered."766 Therefore it reasoned that in the circumstances of the case, Guinean authorities had used excessive force in arresting the vessel and endangered the lives of its crew, and therefore violated the rights of Saint Vincent and the Grenadines under international law. ${ }^{767}$ Arrests made by law enforcement authorities in the oceans are common, and the Tribunal's judgment reminds the states of the world of the procedures and safeguards to be taken in arresting foreign vessels. ${ }^{768}$ Some eminent commentators have noted that the Tribunal's concern for the crew, and the displeasure it expressed at the nature of their violent arrest, has arguably advanced the humanitarian values in international law. ${ }^{769}$ It is submitted that this has a long-term beneficial impact on

\footnotetext{
${ }^{763}$ The $M / V$ "Saiga” (No 2) - Merits, above n 746, para 183 (8).

${ }^{764}$ The M/V "Saiga" (No 2) - Merits, above n 746, para 153.

765 The $M / V$ "Saiga" (No 2) - Merits, above n 746, para 140.

${ }^{766}$ The $M / V$ "Saiga" (No 2) - Merits, above n 746, para 156.

${ }^{767}$ The M/V "Saiga" (No 2) - Merits, above n 746, paras 159 and 183(9).

${ }^{768}$ Louise de La Fayette "International Tribunal for the Law of the Sea: The M/V 'Saiga' (No 2) Case (St Vincent and the Grenadines v Guinea) Judgment" (2000) 49 ICLQ 467, 474.

${ }^{769}$ Bernard Oxman and Vincent P Bantz "The M/V 'Saiga' (No. 2) (Saint Vincent and the Grenadines v, Guinea)" (2000) 94 AJIL 140, 148.
} 
oceans governance, particularly with regard to the respect for human rights ${ }^{770}$ in law enforcement at sea.

\section{The Southern Bluefin Tuna Cases (Provisional Measures)}

The Southern Bluefin Tuna (SBT) (Thynnus maccoyi) is a long-lived, highly migratory fish species that is found in most parts of the temperate oceans of the southern hemisphere, and is greatly sought after due to its high commercial value. ${ }^{771}$ The dispute concerned the SBT and arose from certain differences between its principal fishing nations - New Zealand and Australia (NZ/A) on one side and Japan on the other. ${ }^{772}$ This dispute, in its provisional measures stage as well as in the arbitral proceedings, has spurred a flurry of commentary from writers all over the world. ${ }^{773}$ These cases had a constructive influence on oceans governance by way of (i) facilitation of co-operation between states, (ii) ensuring compliance with laws and norms, (iii) maintenance of the integrity of the principles governing the Convention, and generally (iv) reducing tension and

\footnotetext{
${ }^{770}$ For an interesting article on the human rights element in the LOSC, see Bernard H Oxman "Human Rights and the United Nations Convention on the Law of the Sea" (1997) 36 Colum J Transnatl L 399.

771 Tom Polacheck "Experimental Catches and the Precautionary Approach: The Southern Bluefin Tuna Dispute" (2002) 26 Marine Policy 283, 284; Julia Baldock "Determining the Fate of Southern Bluefin Tuna - International Tribunal for the Law of the Sea (1999) New Zealand v Japan; Australia v Japan" (2000) EPLJ 157, 157. For detailed information on the SBT fishery, see Anthony Bergin and Marcus Haward "Southern Bluefin Tuna Fishery: Recent Developments in International Management" (1994) 18 Marine Policy 263, 271.

${ }^{772}$ For a good background of the dispute, see Cesare Romano "The Southern Bluefin Tuna Dispute: Hints of a World to Come ... Like It or Not" (2001) 32 ODIL 313 ["SBT - Hints of a World to Come"]. For concerns about low stock levels of the SBT, see generally Colin Hunt "Concern for Southern Ocean Fish Stocks and Bird Populations" Marine Policy (Article in Press).

773 For analysis and comments on the provisional measures case, see Robin R Churchill "International Tribunal for the Law of the Sea: The Southern Bluefin Tuna Cases (New Zealand v Japan; Australia v Japan): Order for Provisional Measures of 27 August 1999" (2000) 49 ICLQ 979 ["ITLOS: SBT"]; Malcolm D Evans "The Southern Bluefin Tuna Dispute: Provisional Thinking on Provisional Measures?" (1999) 10 YIEL 7; Teresa Dunworth "Bluefin Tuna" [1999] NZLJ 395; Moritaka Hayashi "The Southern Bluefin Tuna Cases: Prescription of Provisonal Measures by the International Tribunal for the Law of the Sea" (2000) 13 Tul Envtl L J 361; Donald L Morgan "Emerging Fora for International Litigation (Part 1): Implications of the Proliferation of International Legal Fora: The Example of the Southern Bluefin Tuna Cases" (2002) 43 Harv Intl L J 541; Donald L Morgan "A Practitioner's Critique of the Order Granting Provisional Measures in the Southern Bluefin Tuna Cases" in M H Nordquist and J N Moore (eds) Current Marine Environmental Issues and the International Tribunal for the Law of the Sea (Kluwer Law International, The Hague, 2001) 173; Volker Röben "The Sothern Bluefin Tuna Cases: Re-Regionalization of the Settlement of Law of the Sea Disputes?" (2002) 62 (1-2) ZaöRV 61; Caroline E Foster "The 'Real Dispute' in the Southern Bluefin Tuna Case: A Scientific Dispute?” (2001) 16 (4) IJMCL 571.
} 
maintaining peace. These aspects of the jurisprudence are brought out for the purposes of the thesis.

New Zealand, Australia and Japan had agreed to informally manage the SBT stock in 1982 and 1993, formalising their arrangement in the Convention for the Conservation of the Southern Bluefin Tuna ${ }^{774}$ (CCSBT). Management arrangements had broken down in 1998 when NZ/A and Japan were unable to agree on a total allowable catch (TAC) and Japan unilaterally conducted an experimental fishing programme (EFP), which involved non-commercial fishing in unexploited areas of the sea. ${ }^{775}$ NZ/A scientists considered that there was a decline in the SBT stock, while Japanese scientists believed the stock was increasing. ${ }^{776}$ Negotiations on the TAC and the issue of whether the Commission on the CCSBT (C-CCSBT) had sufficient scientific evidence to base its advice had been going on between the parties within the organs of the CCSBT. ${ }^{777}$ In 1999 Japan declared that it intended to re-launch its EFP for the years 1999, 2000 and 2001, leading NZ/A to conclude that negotiations had terminated and to invoke proceedings under the LOSC. ${ }^{778}$

Facing a stalemate over the dispute that was fundamentally a divergence of opinions over the SBT stock, NZ/A instituted arbitral proceedings against Japan under Annex VII of the Convention on 15 July 1999. ${ }^{779}$ The Southern Bluefin Tuna Cases (SBT Cases) reached ITLOS as its first fishery related dispute and were actually two separate Requests for provisional measures under Article 290(5) sent to the ITLOS Registry, a few hours apart on 30 July $1999 .^{780}$ NZ/A alleged in their Notifications instituting the arbitral proceedings that Japan had failed to comply with its obligations to co-operate in the conservation of the

\footnotetext{
${ }^{774}$ Convention for the Conservation of the Southern Bluefin Tuna (10 May 1993) 1819 UNTS 560.

${ }^{775}$ See Shirley V Scott "Australia's First Tuna Negotiations with Japan” (2000) 24 Marine Policy 309, 309. For a Japanese perspective on the nature of the emerging differences between the parties, see Yochiro Sato "Fishy Business: A Political - Economic Analysis of the Southern Bluefin Tuna Dispute" (2002) 28 (4) Asian Affairs: An American Review 217.

${ }^{776}$ Anthony Cox, Matthew Stubbs and Luke Davis Southern Bluefin Tuna and CITES: An Economic Perspective (ABARE Research Report 99, Australian Bureau of Agriculture and Resource Economics, Canberra, 1999) 1.

777 Shabtai Rosenne "International Tribunal for the Law of the Sea: Survey for 1999" (2000) 15 (4) IJMCL 443, 464 - 465 ["International Tribunal for the Law of the Sea: Survey for 1999"].

778 "International Tribunal for the Law of the Sea: Survey for 1999", above 777, 465.

${ }^{779}$ See Southern Bluefin Tuna Cases - Provisional Measures, above n 726.

${ }^{780}$ New Zealand's and Australia's Request for provisional measures reached the Tribunal's Registry at 8.38 am and $2.30 \mathrm{pm}$ respectively. See Southern Bluefin Tuna Cases - Provisional Measures, above n 726, paras 2 and 5.
} 
SBT stock and breached its obligations under Articles 64 and 116 to 119 of the LOSC. ${ }^{781}$ In their Requests for provisional measures before ITLOS, NZ/A asked for five provisional measures pending the constitution of the arbitral tribunal under Annex VII, the foremost of which was to order Japan to cease its unilateral EFP for SBT. ${ }^{782}$ In its Statement in Response, Japan challenged ITLOS's jurisdiction by arguing that the Annex VII tribunal did not have prima facie jurisdiction since the dispute had arisen under the CCSBT and not the LOSC, and since NZ/A had not attempted in good faith to reach a settlement with it under Section 1 of Part XV of the LOSC, compulsory procedures under Section 2 vesting jurisdiction on Annex VII tribunal could not be invoked. ${ }^{783}$

ITLOS held inter alia that the application of the CCSBT between the Parties did not preclude recourse to the dispute settlement procedures under the LOSC. ${ }^{784}$ It also clarified that a state party under the LOSC is not obliged to pursue procedures under Section 1 of Part XV when it has concluded that the possibilities of settlement have been exhausted and therefore in the present case, the requirements for invoking Article 290 of the Convention, had been fulfilled. ${ }^{785}$ The Tribunal found that the arbitral tribunal to be constituted under Annex VII would prima facie have jurisdiction over the dispute and concluded that under the given circumstances, provisional measures were appropriate. ${ }^{786}$

On 27 August 1999, ITLOS “prescribed” six provisional measures, many of which have a significant and constructive impact on oceans governance. ${ }^{787}$ ITLOS ordered the parties to the dispute to ensure that no action was taken that would extend or aggravate the dispute or might prejudice any decision on the merits, which the arbitral tribunal may render. ${ }^{788}$ Cognizant of the fact that the SBT fishery needed conservation, ITLOS ordered that the parties should not exceed their national allocations and, should refrain from conducting any EFP unless that was counted against the relevant national allocation. ${ }^{789}$ Beyond

\footnotetext{
${ }^{781}$ Southern Bluefin Tuna Cases - Provisional Measures, above n 726, paras 28 and 29.

782 Southern Bluefin Tuna Cases - Provisional Measures, above n 726, paras 31 and 32.

${ }^{783}$ Southern Bluefin Tuna Cases - Provisional Measures, above n 726, para 33.

${ }^{784}$ Southern Bluefin Tuna Cases - Provisional Measures, above n 726, para 55.

785 Southern Bluefin Tuna Cases - Provisional Measures, above n 726, paras 60 and 61.

786 Southern Bluefin Tuna Cases - Provisional Measures, above n 726, paras 62 and 85.

${ }^{787}$ See Southern Bluefin Tuna Cases - Provisional Measures, above n 726.

788 Southern Bluefin Tuna Cases - Provisional Measures, above n 726, para 90(a) and (b).

789 See Southern Bluefin Tuna Cases - Provisional Measures, above n 726, paras 77 and 90(c) and (d).
} 
merely playing its part in protecting the SBT stock directly by the above orders, ITLOS went ahead to send NZ/A and Japan back to the negotiation table with a duty to co-operate for the purpose of reaching agreement on the measures for the conservation and management of the SBT. ${ }^{790}$

It did not stop at this conservationist stance either and urged NZ/A and Japan to expend further efforts with other states engaged in fishing the SBT with a view to ensuring an optimum utilisation of the stock. ${ }^{791}$ This measure prescribed by ITLOS is noteworthy because it was probably made in the realisation that conservationist goals and actions by the members of the CCSBT were fine and could be controlled under the regime. But the crisis of the depleting stock was being magnified by "free rider" 792 States, like Indonesia, Korea and Taiwan, who were outside the regime ${ }^{793}$ yet continued to benefit from it and therefore needed to be included in the conservation initiatives. The Tribunal demonstrated great wisdom in reminding the parties that it was imperative for optimum stock conservation that they seek the co-operation of other nations outside the CCSBT which had an interest in the SBT stock.

ITLOS deserves to be applauded for upholding the fact "that the conservation of the living resources of the sea is an element in the protection and preservation of the marine environment." ${ }^{, 794}$ Its praise is further justified because, though it could not conclusively assess the scientific evidence before it, it decided that provisional measures were required as a matter of urgency to preserve the rights of the parties and avert deterioration of the SBT stock. ${ }^{795}$

The ITLOS Order for provisional measures has been widely appreciated, starting with very positive receptions from the respective governments themselves. ${ }^{796}$ Howard Schiffman has welcomed the decision "as a victory for

\footnotetext{
${ }^{790}$ Southern Bluefin Tuna Cases - Provisional Measures, above n 726, para 90(e).

791 Southern Bluefin Tuna Cases - Provisional Measures, above n 726, para 90(f).

${ }^{792}$ Erik Franckx "Pacta Tertiis and the Agreement for the Implementation of the Straddling and Highly Migratory Fish Stocks Provisions of the United Nations Convention on the Law of the Sea" (2000) 8 Tul J Intl \& Comp L 49, 54.

${ }^{793}$ See Cox, Stubbs and Davis, above n 776, 24.

${ }^{794}$ Southern Bluefin Tuna Cases - Provisional Measures, above n 726, para 70.

${ }^{795}$ Southern Bluefin Tuna Cases - Provisional Measures, above n 726, para 80.

796 See New Zealand Ministry of Fisheries "Landmark Decision - New Zealand Tuna Fishing Case" (28 August 1999) Press Release, available at $<$ http://www.fish.govt.nz/current/press/pr990828.htm> (last accessed 1 December 2005); Hon Daryl Williams and Hon Warren Truss “Australia Wins Southern Bluefin Tuna Case" (28 August 1999) Joint Press Release of the Australian Commonwealth Attorney-General and Minister of Agriculture, Fisheries and Forestry, available at
} 
the conservation of fishery resources"797 accomplished by "[t]he clear message of the Tribunal's Order, favouring conservation over additional short-term consumptive utilization ..."798 The Order did not resolve the underlying scientific issues in the dispute or define how the fishery was to be managed best since it was outside its jurisdiction. ${ }^{799}$ However, it did give NZ/A and Japan clear directives underlying the need to keep the dispute under control and at the same time preserving the health of the SBT stock.

Another aspect of the judgment that deserves to be mentioned in this regard, relates to the application of the precautionary principle/ approach by ITLOS. ${ }^{800}$ Legal scholars have traced the development and evolution of the precautionary principle in the past, which basically mandates caution and prudence on the part of responsible parties in the face of scientific uncertainty. ${ }^{801}$ Orellana notes that ITLOS used this case "to elaborate further on the precautionary principle" 802 and Marr suggests that this was "the first time in international environmental law, an international court prescribed environmental

\footnotetext{
$<$ http://www.ag.gov.au/agd/WWW/attorneygeneralHome.nsf/Page/Media_Releases_1999_Augus t_Australia_wins_southern_bluefin_tuna_case > (last accessed 1 December 2005); Ministry of Foreign Affairs of Japan "Statement by Foreign Minister Masahiko Koumura on the International Tribunal for the Law of the Sea's Order on the Request for Provisional Measures Concerning Japan's Experimental Fishing Program on Southern Bluefin Tuna" (27 August 1999) Press Release, available at <http://www.mofa.go.jp/announce/announce/1999/8/827.html> (last accessed 1 December 2005).

797 Howard S Schiffman "The Southern Bluefin Tuna Case: ITLOS Hears Its First Fishery Dispute" (1999) 2 (3) JIWLP 1, 15 ["The Southern Bluefin Tuna Case: ITLOS Hears Its First Fishery Dispute"].

798 “The Southern Bluefin Tuna Case: ITLOS Hears Its First Fishery Dispute”, above n 797, 12.

${ }^{799}$ Baldock, above $\mathrm{n} 771,164$.

${ }^{800}$ For detailed analyses of the application of this legal doctrine by ITLOS in the SBT Cases and possible implications, see Adriana Fabra "The LOSC and the Implementation of the Precautionary Principle" (1999) 10 YIEL 15; David Freestone "Caution or Precaution: "A Rose by Any Other Name...?" (1999) 10 YIEL 27; Francisco Orrego Vicuña "From the 1893 Bering Sea Fur-Seals Case to the 1999 Southern Bluefin Tuna Cases: A Century of Efforts at Conservation of the Living Resources of the High Seas" (1999) 10 YIEL 41.

801 See generally the collection of essays in David Freestone and Ellen Hey (eds) The Precautionary Principle and International Law: The Challenge of Implementation (Kluwer Law International, Boston, 1995); Arie Trouwborst Evolution and Status of the Precautionary Principle in International Law (Kluwer Law International, The Hague, 2002); Sonia Boutillon "The Precautionary Principle: Development of an International Standard" (2002) 23 Mich J Intl L 429; Jacqueline Peel "Precaution - A Matter of Principle, Approach or Process" (2004) 5 Melb J Intl L 483; Jon M Van Dyke "The Evolution and International Acceptance of the Precautionary Principle" in David D Caron and Harry N Scheiber (eds) Bringing New Law to Ocean Waters (Martinus Nijhoff Publishers, Leiden, 2004) 357; Daniel Bodansky "Deconstructing the Precautionary Principle" in David D Caron and Harry N Scheiber (eds) Bringing New Law to Ocean Waters (Martinus Nijhoff Publishers, Leiden, 2004) 381; Stuart M Kaye International Fisheries Management (Kluwer Law International, The Hague, 2001), 163 - 257.

${ }^{802}$ Marcos A Orellana "The Law on Highly Migratory Fish Stocks: ITLOS Jurisprudence in Context" (2004) 34 Golden Gate U L Rev 459, 489.
} 
action in the face of scientific uncertainties." 803 Vicuña has previously explained the difficulty in applying the precautionary principle in fisheries management owing to the scientific uncertainty that generally pervades it. ${ }^{804}$

The precautionary aspect of the judgment was highlighted in few of the Separate Opinions submitted in this case by Judges Laing, Treves and Judge ad hoc Shearer. Judge Laing argued that the LOSC has a precautionary approach and though the Tribunal's Order did not specifically refer to the precautionary principle, it "adopted the precautionary approach" in the present case. ${ }^{805}$ Similarly, Judge Treves has asserted that a precautionary approach is "inherent in the very notion of provisional measures." ${ }^{806}$ Judge ad hoc Shearer too devoted a significant portion his Separate Opinion to support the view that the measures prescribed by ITLOS were correctly based upon considerations deriving from a precautionary approach. ${ }^{807}$ The Tribunal's application of this legal doctrine is commendable, which though unconventional and arguably difficult to implement in adjudication, has great potential for effective environmental management and conservation. $^{808}$

There is one other aspect of the dispute that deserves mention. This dispute primarily arose out of a disagreement between the disputants on the scientific evidence about the SBT stocks levels. It needs to be stressed that scientific findings that measure the state of the oceans must maintain sufficient credibility in the understanding of all interested parties having a say in the oceans governance process. ${ }^{809}$ Since this case was only a request for provisional measures, the need for scientific evidence in guiding the dispute settlement

803 Simon Marr "The Southern Bluefin Tuna Cases: The Precautionary Approach and Conservation and Management of Fish Resources" (2000) 11 (4) EJIL 815, 830.

${ }^{804}$ Francisco Orrego Vicuña The Changing International Law of High Seas Fisheries (Cambridge University Press, Cambridge, 1999) 157.

${ }^{805}$ Southern Bluefin Tuna Cases (New Zealand v Japan; Australia v Japan) (Provisional Measures) [1999] <http://www.itlos.org/> (last accessed 1 December 2005) paras 13, 17 and 19, Judge Laing's Separate Opinion.

806 Southern Bluefin Tuna Cases (New Zealand v Japan; Australia v Japan) (Provisional Measures) [1999] <http://www.itlos.org/> (last accessed 1 December 2005) para 9 Judge Treves's Separate Opinion.

${ }^{807}$ Southern Bluefin Tuna Cases (New Zealand v Japan; Australia v Japan) (Provisional Measures) [1999] <http://www.itlos.org/> (last accessed 1 December 2005) Shearer's Separate Opinion [Southern Bluefin Tuna Cases - Shearer].

${ }^{808}$ Thomas A Telesca "Sovereignty or the Precautionary Principle: Which Will Save Our Fish?" (2003) 12 Southeastern Envtl L J 23, 72.

${ }^{809}$ See Richard J Silk Jr "Nonbinding Dispute Resolution Processes in Fisheries Conflicts: Fish Out of Water?" (2001) Ohio St J on Disp Resol 791, 818. 
process was not very high. However, that would not have been the case, had this been a dispute on the merits. Hence it can be recommended that for dispute settlement procedures to have beneficial role in oceans governance, it must be guided by scientific advice in relevant cases, which are acceptable to the disputant parties.

In conclusion, it can be reiterated that the SBT Cases at ITLOS have made a distinct and constructive contribution to oceans governance. Douglas Johnston has noted that one of the most valuable contributions of ITLOS in the SBT Cases, has been its willingness “... to adopt a facilitative, problem-solving approach ... ${ }^{, 810}$ Further, he argues: ${ }^{811}$

\begin{abstract}
... the willingness of a tribunal, especially one of a specialized nature, to "assist the parties in resolving their dispute amicably" should be applauded. This facilitative function of modern international adjudication should in no way be relegated to a lower position than the more traditional resolutive and declaratory functions.
\end{abstract}

ITLOS acted as "an agency of diplomacy" 812 in this case, encouraging co-operation and positive dialogue between the parties. Despite its lack of scientific expertise and knowledge, which are indispensable to greater long-term conservation initiatives, it also acted like a “... [knight] in shining armour riding to the rescue of the endangered..." ${ }^{813}$ SBT.

\title{
D The Southern Bluefin Tuna Case (Jurisdiction and Admissibility)
}

The SBT Cases were followed by the proceedings before the Annex VII arbitral tribunal that delivered its Award on Jurisdiction and Admissibility (Award) on 4 August 2000. ${ }^{814}$ This decision has been the centre of controversy,

\footnotetext{
${ }^{810}$ Douglas M Johnston "Fishery Diplomacy and Science and the Judicial Function" (1999) 10 YIEL 33, 39 ["Fishery Diplomacy and Science and the Judicial Function"].

811 "Fishery Diplomacy and Science and the Judicial Function", above n 810, 38 (emphasis in original).

${ }^{812}$ Southern Bluefin Tuna Cases - Shearer, above n 807.

813 "ITLOS: SBT", above n 773, 989.

${ }^{814}$ Southern Bluefin Tuna Case - Australia and New Zealand v Japan (Australia and New Zealand $v$ Japan) (Jurisdiction and Admissibility) [2000], available at $<$ http://www.worldbank.org/icsid/bluefintuna/award080400.pdf $>$ (last accessed 1 December 2005), Judgment of the majority [Southern Bluefin Tuna Case - Jurisdiction and Admissibility]. Other relevant documents of the proceedings may be found at $<$ http://www.worldbank.org/icsid/bluefintuna/main.htm $>$ (last accessed 1 December 2005). The tribunal was composed of Judge Stephen M Schwebel (President), HE Judge Florentino
} 
and has received more criticism than praise from commentators. ${ }^{815}$ For example, one commentator has opined that, though the LOSC had the potential to effectively manage and conserve fisheries, the Award has "squashed any such hopes." 816 Another author has criticised that "[t]he decision strikes a blow to the environmental movement, as well as throws the compulsory jurisdiction of the United Nations Convention for the Law of the Sea into jeopardy." ${ }^{817}$ The Award has drawn high interest in several respects, one of which is the fact that it was rendered by the first arbitral tribunal constituted under Annex VII of the Convention. ${ }^{818}$ Since a detailed exposition of most of the pertinent aspects of the Award is beyond the scope of the present thesis, what follows is a brief account of the Award highlighting those features that had the most immediate impacts on oceans governance.

The hearings in this case began on 7 May 2000 at the World Bank headquarters in Washington DC. ${ }^{819}$ As with the SBT Cases, Japan challenged the jurisdiction of the arbitral tribunal on many grounds, arguing inter alia that the dispute was one under the CCSBT and not the LOSC; ${ }^{820}$ the dispute was a scientific one and hence not justiciable; ${ }^{821}$ and the dispute was moot since it had accepted a lower catch limit for its EFP and had agreed pay back all excess catches above this limit. ${ }^{822} \mathrm{NZ} / \mathrm{A}$ in their counter-argument repeated ITLOS's

Feliciano, The Rt Hon Justice Sir Kenneth Keith, HE Judge Per Tresselt and Professor Chusei Yamada.

${ }^{815}$ For a range of criticisms, see David A Colson and Peggy Hoyle "Satisfying the Procedural Prerequisites to the Compulsory Dispute Settlement Mechanisms of the 1982 Law of the Sea Convention: Did the Southern Bluefin Tuna Tribunal Get it Right?" (2003) 34 ODIL 59; Alan E Boyle "The Southern Bluefin Tuna Arbitration" (2001) 50 ICLQ 447; D J Devine "Compulsory Dispute Settlement in UNCLOS Undermined?" (2000) 25 SAYIL 97; Deborah Horowitz "The Catch of Poseidon's Trident: The Fate of High Seas Fisheries in the Southern Bluefin Tuna Case" (2001) 25 Melb U L Rev 810.

816 Telesca, above n 808, 64 .

${ }^{817}$ Leah Sturtz "Southern Bluefin Tuna Case: Australia and New Zealand v Japan" (2001) 28 Ecology L Q 455, 455.

${ }^{818}$ Stephen M Schwebel "The Southern Bluefin Tuna Case" in Nisuke Endo and others (eds) Liber Amicorum Judge Shigeru Oda (vol 1, Kluwer Law International, The Hague, 2002) 743. For some extra-judicial comments made by one of the other arbitrators in the case, see Chusei Yamada "Priority Application of Successive Treaties Relating to the Same Subject Matter: The Southern Bluefin Tuna Case" in Nisuke Endo and others (eds) Liber Amicorum Judge Shigeru Oda (vol 1, Kluwer Law International, The Hague, 2002) 763.

${ }^{819}$ Southern Bluefin Tuna Case - Jurisdiction and Admissibility, above n 814, para 100.

${ }^{820}$ Southern Bluefin Tuna Case - Jurisdiction and Admissibility, above n 814, paras 38(a) - (j) and 39(a) - (c).

${ }^{821}$ Southern Bluefin Tuna Case - Jurisdiction and Admissibility, above n 814, para 40 (a). For a detailed comment on this point, see Foster, above n 773.

${ }^{822}$ Southern Bluefin Tuna Case - Jurisdiction and Admissibility, above n 814, para 40(c). 
reasoning that the dispute arose under both the LOSC and CCSBT; ${ }^{823}$ asserted that the dispute was not excluded from the compulsory procedures under Part XV of the Convention; ${ }^{824}$ argued that the dispute was a legal one since it concerned the primacy of conservation of a seriously depleted fish stock; ${ }^{825}$ argued that all jurisdictional requirements under Part XV of the Convention had been met; ${ }^{826}$ and that Japan's latest proposals did not make the proceedings moot since the quality of the EFP was the central issue and remained unchanged. ${ }^{827}$

At the outset, the tribunal agreed with NZ/A and declared that the case was not moot. ${ }^{828}$ It identified that the most acute elements of the dispute between the Parties turned on their inability to agree on a revised TAC, and Japan's past EFP and plans for future ones. ${ }^{829}$ It also concluded that treaty parallelism was a common phenomenon under international law and that the dispute arose both under the CCSBT as well as the LOSC. ${ }^{830}$ The tribunal then went on to reason that by the operation of Article 16 of the CCSBT and Article 281(1) of the LOSC, the jurisdiction for the dispute was taken out of the purview of Part XV of the LOSC. ${ }^{831}$ Finally it ruled that it did not have jurisdiction to entertain the merits of the case brought by NZ/A against Japan. ${ }^{832}$ Only Justice Kenneth Keith dissented from the majority's judgment and appended a well-reasoned Separate Opinion in which he opined that Article 16(1) of the CCSBT did not exclude the jurisdiction of the tribunal under the LOSC. ${ }^{833}$

\footnotetext{
${ }^{823}$ Southern Bluefin Tuna Case - Jurisdiction and Admissibility, above n 814, paras 41(a) and 41(h).

${ }^{824}$ Southern Bluefin Tuna Case - Jurisdiction and Admissibility, above n 814, paras 41(b) and 41(e).

${ }^{825}$ Southern Bluefin Tuna Case - Jurisdiction and Admissibility, above n 814, para 41(c).

${ }^{826}$ Southern Bluefin Tuna Case - Jurisdiction and Admissibility, above n 814, paras 41(g), 41(i), 41(j) and 41(k).

${ }^{827}$ Southern Bluefin Tuna Case - Jurisdiction and Admissibility, above n 814, para 41(m).

${ }^{828}$ Southern Bluefin Tuna Case - Jurisdiction and Admissibility, above n 814, para 46.

${ }^{829}$ Southern Bluefin Tuna Case - Jurisdiction and Admissibility, above n 814, para 49.

${ }^{830}$ Southern Bluefin Tuna Case - Jurisdiction and Admissibility, above n 814, para 52. On the issue of treaty parallelism, see Bernard H Oxman and Barbara Kwiatkowska "Arbitration Jurisdictional Effect of Different Dispute Settlement Provisions in Related Treaties - High Seas Fishing - Relationship between UN Convention on the Law of the Sea and Specialized Treaties" (2001) AJIL 162; Bernard H Oxman "Complementary Agreements and Compulsory Jurisdiction" (2001) 95 AJIL 277.

${ }^{831}$ Southern Bluefin Tuna Case - Jurisdiction and Admissibility, above n 814, paras 53 - 59 .

${ }^{832}$ Southern Bluefin Tuna Case - Jurisdiction and Admissibility, above n 814, paras 65 and 72(1).

${ }^{833}$ Southern Bluefin Tuna Case - Australia and New Zealand v Japan (Australia and New Zealand $v$ Japan) (Jurisdiction and Admissibility) [2000], available at $<$ http://www.worldbank.org/icsid/bluefintuna/opinion.pdf $>$ (last accessed 1 December 2005), Justice Keith dissenting.
} 
Though the Award has qualified as “... a rare example of an arbitral body prepared to decline jurisdiction and take the adventurous step of implying the exclusion of compulsory dispute settlement ..." ${ }^{834}$ under the LOSC by the provisions of the CCSBT, the constructive aspects of the Award deserve mention. Kwiatkowska has argued that the most important contribution of the arbitral tribunal has been the inducements it provided to the Parties to reach a successful settlement, which they did in May 2001. ${ }^{835}$ She also argued at length about the Award's paramount contributions to the dispute settlement system of the Convention and hoped that they would assist governments and other judicial bodies to promote solutions to strengthen the legal regime of the oceans and international law in general. ${ }^{836}$ Bill Mansfield has noted in this regard that the case has demonstrated how in "... assisting in the resolution of the dispute, the dispute settlement process itself, including the comments and signals from relevant tribunal or tribunals, may be of more importance than the formal elements of any decision." 837 Similarly, Romano has suggested that though the Award or the ITLOS Order could not settle the dispute, they were successful in breaking the "diplomatic impasse" that had affected the parties since mid1990s. ${ }^{838}$

Stephens has opined that the SBT litigation played a constructive role in helping the C-CCSBT to begin functioning again, and productive negotiations at scheduled and inter-sessional meetings produced settlement on specific disputes. $^{839}$ Again, Peel notes that though the arbitral tribunal refused

\footnotetext{
${ }^{834}$ Dean Bialek "Australia \& New Zealand v Japan: Southern Bluefin Tuna Case” (2000) 1 Melb J Intl L 153, 160.

${ }^{835}$ Barbara Kwiatkowska "The Southern Bluefin Tuna Award (Jurisdiction and Admissibility) in Nisuke Endo and others (eds) Liber Amicorum Judge Shigeru Oda (vol 1, Kluwer Law International, The Hague, 2002) 697, 721. She has expressed further support for the Award in Barbara Kwiatkowska "The Southern Bluefin Tuna Arbitral Tribunal Did Get it Right: A Commentary and Reply to the Article by David A. Colson and Dr. Peggy Hoyle" (2003) 34 ODIL 369.

${ }^{836}$ Barbara Kwiatkowska "The Australia and New Zealand v Japan Southern Bluefin Tuna (Jurisdiction and Admissibility) Award of the First Law of the Sea Convention Annex VII Arbitral Tribunal" (2001) 16 (2) IJMCL 239, 293.

${ }^{837}$ Bill Mansfield "The Southern Bluefin Tuna Arbitration: Comments on Professor Barbara Kwiatkowska's Article" (2001) 16 (2) IJMCL 361, 362. For similar comments, see Bill Mansfield "Compulsory Dispute Settlement after the Southern Bluefin Tuna Award" in Alex G Oude Elferink and Donald R Rothwell (eds) Oceans Management in the 21st Century: Institutional Frameworks and Responses (Martinus Nijhoff Publishers, Leiden, 2004) 255, 265.

838 "SBT - Hints of a World to Come", see above n 772, 334.

${ }^{839}$ Tim Stephens "The Limits of International Adjudication in International Environmental Law: Another Perspective on the Southern Bluefin Tuna Case" (2004) 19 (2) IJMCL 177, 186.
} 
jurisdiction, the process of resorting to the Convention's dispute settlement procedures “... clearly had beneficial results, not the least of which has been to remove the previous political deadlock within the [C-CCSBT]." ${ }^{, 40}$ This author concurs with the conclusions of the many writers referred to in this paragraph and the preceding one. In comparison to the provisional measures Order, the Award arguably achieved much less, even by its facilitative role in oceans governance. Nevertheless, its contribution encapsulated by many prominent authors cannot go unnoticed.

Before concluding this section, one critical aspect of this Award must be pointed out. Serious allegations have been made against the Award arguing that they have undermined the effect of the compulsory dispute settlement procedures of the LOSC. As Joanna Mossop puts it, this “... case that had the potential to clarify some of the broadest and most important provisions in the Convention failed at the jurisdiction stage." 841 The tribunal's reasoning in rejecting jurisdiction in the case has led to great uncertainty and confusion, which can possibly be cleared by an authoritative judicial decision in the future. ${ }^{842}$ This case brought to life some of the fears relating to the consequences of the rapid growth of international courts and tribunals in recent years. There is vast volume of literature dealing with the "proliferation" 843 of international courts and tribunals, and commentators have cautioned about jurisdictional conflicts ${ }^{844}$ and

\footnotetext{
${ }^{840}$ Jacqueline Peel "A Paper Umbrella which Dissolves in the Rain? The Future for Resolving Fisheries Disputes under UNCLOS in the Aftermath of the Southern Bluefin Tuna Arbitration" (2002) 3 Melb J Intl L 53, 74.

${ }^{841}$ Joanna Mossop "Book Review: Dispute Settlement in the UN Convention on the Law of the Sea" (2005) 36 VUWLR 867, 869.

${ }^{842}$ Alan Boyle "Some Problems of Compulsory Jurisdiction before Specialised Tribunals: The Law of the Sea" in Patrick Capps, Malcolm Evans and Strato Konstadinidis (eds) Asserting Jurisdiction: International and European Legal Perspectives (Hart Publishing, Portland (Oregon), 2003) 243, 251.

843 See Jonathan I Charney "Is International Law Threatened by Multiple International Tribunals?" (1998) 271 Recueil des Cours 115; Gerhard Hafner "Should One Fear the Proliferation of Mechanisms for the Peaceful Settlement of Disputes?" in Lucius Caflisch (ed) The Peaceful Settlement of Disputes Between States: Universal and European Perspectives (Kluwer Law International, The Hague, 1998) 25; Benedict Kingsbury 'Is the Proliferation of International Courts and Tribunals a Systemic Problem?” (1999) 31 N Y U J Intl L \& Pol 679; Vaughan Lowe "Overlapping Jurisdiction in International Tribunal" (1999) 20 Aust YBIL 191. On some steps recommended to avoid conflicting dispute settlement options, see August Reinisch "The Use and Limits of Res Judicata and Lis Pendens as Procedural Tools to Avoid Conflicting Dispute Settlement Outcomes" (2004) 3 LPICT 37.

${ }^{844}$ See Carl-August Fleischhauer "The Relationship Between the International Court of the Justice and the Newly Created International Tribunal for the Law of the Sea in Hamburg" (1997) 1 Max Planck Yrbk UN L 327; Tullio Treves "Conflicts Between the International Tribunal for the Law of the Sea and the International Court of Justice" (1999) 31 N Y U J Intl L \& Pol 809;
} 
the fragmentation ${ }^{845}$ of international law. However, another school of thought has found little cause for concern in the multiplication of international judicial bodies, and have often praised the development as a positive development. ${ }^{846}$ The Award proved the some of the worst fears resulting from the proliferation of international judicial bodies.

\section{E The MOX Plant Case (Provisional Measures)}

Ireland instituted proceedings against the United Kingdom under Annex VII of the Convention on 25 October $2001 .{ }^{847}$ Pending the constitution of the arbitral tribunal, Ireland filed a Request for provisional measures with ITLOS under Article 290(5) of the Convention on 9 November 2001, in the matter of a dispute concerning the MOX plant, international movement of radioactive materials, and the protection of the marine environment of the Irish Sea, between Ireland and the United Kingdom. ${ }^{848}$

Karin Oellers-Frahm "Multiplication of International Courts and Tribunals and Conflicting Jurisdiction - Problems and Possible Solutions" (2001) 5 Max Planck Yrbk UN L 67; Yuval Shany The Competing Jurisdictions of International Courts and Tribunals (Oxford University Press, Oxford, 2003).

${ }^{845}$ See Pierre-Marie Dupuy "Danger of Fragmentation or Unification of the International Legal System and the International Court of Justice" (1999) 31 N Y U J Intl L \& Pol 791.

${ }^{846}$ See Jonathan I Charney "The Impact on the International Legal System of the Growth of International Courts and Tribunals" (1999) 31 N Y U J Intl L \& Pol 697; Tullio Treves “Advisory Opinions of the International Court of Justice on Questions Raised by Other International Tribunals" (2000) 4 Max Planck Yrbk UN L 215; D W Prager "The Proliferation of International Judicial Organs: The Role of the International Court of Justice" in Niels M Blokker and Henry G Schermers (eds) Proliferation of International Organizations: Legal Issues (Kluwer Law International, The Hague, 2001) 278, 279; Tullio Treves "Judicial Lawmaking in an Era of 'Proliferation' of International Courts and Tribunals: Development or Fragmentation of International Law?" in Rüdiger Wolfrum and Volker Röben (eds) Developments of International Law in Treaty Making (Springer, Berlin, 2005) 586; Pemmaraju Sreenivasa Rao "Multiple International Judicial Forums: A Reflection of the Growing Strength of International Law or its Fragmentation?" (2004) 25 Mich J Intl L 929.

${ }^{847}$ For a short case note, see Darren Abrahams "International Tribunal for the Law of the Sea The Mox Plant Case (Ireland v United Kingdom), Request for Provisional Measures" (2002) 14 (3) JEL 398.

${ }^{848}$ The MOX Plant Case - Provisional Measures, above n 727, para 2. The MOX plant is a nuclear installation operating at Sellafield in the UK. For a background to the dispute and the nature of the MOX plant as a nuclear facility, see Malcolm J C Forster "The MOX Plant Case Provisional Measures in the International Tribunal for the Law of the Sea" (2003) 16 LJIL 611, 612; Robin Churchill and Joanne Scott "The MOX Plant Litigation: The First Half-life" (2004) 53 ICLQ 643, 643. For a discussion on the controversies surrounding the shipment of highly radioactive substances and its implications for the law of the sea, see Robert Nadelson "After MOX: The Contemporary Shipment of Radioactive Substances in the Law of the Sea" (2000) 15 (2) IJMCL 193. 
Ireland claimed that the United Kingdom had breached its obligations under the Convention, in particular Articles 192, 193, 194, 206, 207, 211 and 213. ${ }^{849}$ Ireland requested inter alia that ITLOS order the United Kingdom to suspend the authorisation or prevent the operation of the MOX plant and to ensure that there is no movement of radioactive wastes into and out of the Irish territorial waters in connection with the MOX plant. ${ }^{850}$ The United Kingdom challenged the Tribunal's jurisdiction by arguing that by the operation of Article 282 of the Convention, the Annex VII tribunal would not have jurisdiction over the dispute since Ireland's complaints related to matters that were governed by regional agreements providing for alternative and binding means for dispute settlement. ${ }^{851}$ The United Kingdom pointed out that Ireland had submitted a similar dispute under the 1992 Convention for the Protection of the Marine Environment of the North-East Atlantic ${ }^{852}$ (OSPAR Convention) to an arbitral tribunal. ${ }^{853}$ The United Kingdom further contended that the Treaty establishing the European Community ${ }^{854}$ (EC Treaty) or the Treaty establishing the European Atomic Energy Community ${ }^{855}$ (Euratom Treaty) governed certain aspects of Ireland's complaints, and therefore, the Court of Justice of the European Communities (ECJ) had exclusive jurisdiction to deal with those disputes. ${ }^{856}$ The United Kingdom also argued that the requirements under Article 283 of the Convention had not been met, since there was no exchange of views regarding the settlement of the dispute. ${ }^{857}$

ITLOS tackled the tricky issue of treaty parallelism ${ }^{858}$ well in declaring that the OSPAR Convention, EC Treaty or the Euratom Treaty did not deal with

\footnotetext{
${ }^{849}$ The MOX Plant Case - Provisional Measures, above n 727, para 26.

${ }^{850}$ The MOX Plant Case - Provisional Measures, above n 727, para 27(1) and (2).

${ }^{851}$ The MOX Plant Case - Provisional Measures, above n 727, paras 37 - 39.

${ }^{852}$ Convention for the Protection of the Marine Environment of the North-East Atlantic, (21 September 1992), (1993) 31 ILM 1312. The OSPAR Convention, to which there are 16 parties, is designed to regulate all sources of pollution in the maritime area of the North-east Atlantic.

${ }^{853}$ The MOX Plant Case - Provisional Measures, above n 727, para 40. The arbitral tribunal in the present case had been called upon to determine whether UK had violated art 9 of the OSPAR Convention by not providing information that Ireland had requested concerning the MOX Plant.

${ }^{854}$ Treaty of Amsterdam Amending the Treaty on European Union, the Treaties Establishing the European Communities and Certain Related Acts (2 October 1997) [1997] OJ C 340/1 [EC Treaty].

${ }^{855}$ Treaty Establishing the European Atomic Energy Community (25 March 1957) 298 UNTS 259.

${ }^{856}$ The MOX Plant Case - Provisional Measures, above n 727, para 41.

${ }^{857}$ The MOX Plant Case - Provisional Measures, above n 727, para 54.

${ }^{858}$ For a discussion, see Barbara Kwiatkowska "The Ireland $v$ United Kingdom (Mox Plant) Case: Applying the Doctrine of Treaty Parallelism” (2003) 18 (1) IJMCL 1.
} 
disputes under the LOSC and concluded that the Annex VII arbitral tribunal would have prima facie jurisdiction in the case. ${ }^{859}$ However, putting on record some of the assurances given by the United Kingdom regarding the transportation of radioactive material through the Irish Sea, ${ }^{860}$ it correctly found that the element of urgency required for the prescription of provisional measures had not been satisfied and therefore decided not to grant the far-reaching provisional measures that Ireland sought. ${ }^{861}$

Nevertheless, on 3 December 2001, ITLOS rendered its Order prescribing provisional measures in the MOX Plant Case, which was delivered in its characteristic facilitative approach as demonstrated in the $M / V$ "Saiga" (No 2) Case and SBT Cases. ${ }^{862}$ In what was arguably the Tribunal's best contribution to oceans governance in this case, it unanimously ordered the Parties to co-operate with each other and forthwith enter into consultations with each other to - (a) exchange further information about the possible consequences resulting to the Irish Sea resulting from the MOX plant, (b) monitor the risks for the Irish Sea arising from the operation of the MOX plant, and (c) devise measures to prevent pollution in the Irish Sea that might result from the functioning of the MOX plant. ${ }^{863}$ ITLOS pronounced that "prudence and caution require that Ireland and the United Kingdom cooperate in exchanging information concerning risks or effects of the operation of the MOX plant and in devising ways to deal with them $\ldots{ }^{, 864}$ Further, ITLOS clarified: ${ }^{865}$

[T]he duty to cooperate is a fundamental principle in the prevention of pollution of the marine environment under Part XII of the Convention and general international law and that rights arise therefrom which the Tribunal may consider appropriate to preserve under article 290 of the Convention.

This was probably "the most enduring part of its Order" $" 866$ and ITLOS deserves praise for making this important judicial pronouncement that is

\footnotetext{
${ }^{859}$ The MOX Plant Case - Provisional Measures, above n 727, paras 48, 49, 53 and 62.

${ }^{860}$ The MOX Plant Case - Provisional Measures, above n 727, paras 78 and 79.

861 The MOX Plant Case - Provisional Measures, above n 727, para 81. Chester Brown "Provisional Measures Before the ITLOS: The MOX Plant Case" (2002) 17 (2) IJMCL 267, 287.

${ }^{862}$ D J Devine "Provisional Measures Ordered by the International Tribunal for the Law of the Sea in the Area of Pollution" (2003) 28 SAYIL 263, 263.

${ }^{863}$ The MOX Plant Case - Provisional Measures, above n 727, para 89(1).

${ }^{864}$ The MOX Plant Case - Provisional Measures, above n 727, para 84.

${ }^{865}$ The MOX Plant Case - Provisional Measures, above n 727, para 82.

${ }^{866}$ Forster, above n 848, 618.
} 
significant for international law in general and the law of the sea in particular. Judge Wolfrum, in his Separate Opinion, further supported the Tribunal's approach by stating that this obligation to co-operate with other states whose rights may be affected is a "Grundnorm" or a fundamental norm of Part XV of the Convention as well as customary international law for the protection of the environment. $^{867}$

Another constructive element of the Tribunal's Order lies in its indirect affirmation of “... the originating state's duty to assess transboundary environmental impacts and associated obligations of consultation and information exchange with affected states." ${ }^{868}$ Further, as Hassan has noted: ${ }^{869}$

This case made a significant contribution to international law relating to [landbased sources of marine pollution] control by helping define the scope of Part $\mathrm{XV}$ of the LOSC concerning compulsory provisional measures to resolve an international dispute also covered by another international agreement.

It is fair to surmise that this pronouncement has long-term constructive ramifications for oceans governance for the present as well as the future.

\section{F The MOX Plant Case (Further Provisional Measures)}

The Annex VII arbitral tribunal formed in February 2002 to hear the merits of Ireland's dispute with the United Kingdom regarding the authorisation and operation of the MOX plant chose the International Bureau of the PCA as its Registry. ${ }^{870}$ Despite the ITLOS affirmative ruling on prima facie jurisdiction, the five-member tribunal was concerned about jurisdictional issues relating to European Community (EC) laws overlapping with its own jurisdiction under the LOSC, and therefore decided to suspend the proceedings till 1 December

867 The MOX Plant Case (Ireland $v$ United Kingdom) (Provisional Measures) [2001] $<\mathrm{http}$ ://www.itlos.org/> (last accessed 1 December 2005) Separate Opinion of Judge Wolfrum.

${ }^{868}$ Maki Tanaka "Lessons from the Protracted MOX Plant Dispute: A Proposed Protocol on Marine Environmental Impact Assessment to the United Nations Convention on the Law of the Sea” (2004) 25 Mich J Intl L 337, 384 ["Lessons from the Protracted MOX Plant Dispute"].

${ }^{869}$ Daud Hassan "International Conventions Relating to Land-based Sources of Marine Pollution Control: Applications and Shortcomings” (2004) 16 Geo Intl Envtl L Rev 657.

${ }^{870}$ The MOX Plant Case (Ireland v United Kingdom) (Suspension of Proceedings on Jurisdiction and Merits, and Request for Further Provisional Measures) [2003] <http://www.pca-cpa.org/> (last accessed 1 December 2005), para 5 [MOX Plant - Suspension of Proceedings]. 
2003. ${ }^{871}$ Since on 16 June 2003 Ireland had made a Request for Further Provisional Measures, ${ }^{872}$ the arbitral tribunal by its Order of 24 June 2003 prescribed a few provisional measures. ${ }^{873}$

In the above Order the arbitral tribunal affirmed the provisional measures prescribed by ITLOS, but not being satisfied about any urgent or serious risk of irreparable harm to Ireland's claimed rights, refused to grant the provisional measures sought. ${ }^{874}$ However, concerned that the co-operation and consultation between the Parties had not always been as timely and effective as possible even after the ITLOS Order, the arbitral tribunal ordered the Parties to submit periodic reports on information and compliance to it. ${ }^{875}$ It attributed the reduced level of co-operation and consultation to the absence of suitable inter-governmental mechanisms between the Parties and recommended that they seek to address this deficiency. ${ }^{876}$

On 30 October 2003, the Commission of the European Communities (EC Commission) brought a formal Action against Ireland in the ECJ on the grounds of non-compliance with certain EC laws, which prohibit member states from employing alternative modes of dispute settlement for matters concerning the implementation and application of EC laws. ${ }^{877}$ On the basis of information received from Ireland about the developments in the resolution of EC law issues, the arbitral tribunal decided on 14 November 2003 to suspend the proceedings before it until the ECJ delivered its judgment or it decided otherwise. ${ }^{878}$

The proceedings instituted by Ireland against the United Kingdom under the OSPAR Convention have concluded, ${ }^{879}$ though some commentators have

\footnotetext{
${ }^{871}$ MOX Plant - Suspension of Proceedings, above n 870, paras 28 - 30 .

${ }^{872}$ In the Dispute Concerning the MOX Plant, International Movement of Radioactive Materials, and the Protection of the Marine Environment of the Irish Sea (Ireland $v$ United Kingdom) (Request for Further Provisional Measures) <http://www.pca-cpa.org/> (last accessed 1 December 2005).

${ }^{873}$ MOX Plant - Suspension of Proceedings, above n 870, para 70.

${ }^{874}$ MOX Plant - Suspension of Proceedings, above n 870, paras 70(2) and (3), 62 and 63.

${ }^{875}$ MOX Plant - Suspension of Proceedings, above $\mathrm{n} 870$, paras 66 and 70(7).

${ }^{876}$ MOX Plant - Suspension of Proceedings, above n 870, paras 66 and 67.

877 Action brought on 30 October 2003 by the Commission of the European Communities against Ireland, Case C-459/03, [2004] OJ C 7/24.

${ }^{878}$ The MOX Plant Case (Ireland v United Kingdom) (Further Suspension of Proceedings on Jurisdiction and Merits) [2003] <http://www.pca-cpa.org/> (last accessed 1 December 2005), para 1(a).

${ }^{879}$ See Ted L McDorman "OSPAR Convention - Access to Information - Environmental Information - Interpretation of Treaties" (2004) 98 AJIL 330; Yuval Shany "The First MOX Plant Award: The Need to Harmonize Competing Environmental Regimes and Dispute
} 
anticipated that the proceedings under the LOSC “... appear destined to continue for several more years" $" 880$ and that "there could be further twists and turns before a complete resolution of the entangled dispute. $" 881$ Churchill and Scott have argued that the next phase of the litigation, assuming that it continues, would be more interesting to academic lawyers, since either the ECJ or the Annex VII arbitral tribunal "will have to rule on the scope of the obligations under [the LOSC] relating to environmental impact assessment, cooperation over protection of the marine environment, and the control of land-based pollution." $\$ 82$

It can be argued that the arbitral tribunal's approach in this case has significantly contributed to good oceans governance. The arbitral tribunal has demonstrated great regard for the dictates of mutual respect and comity that are desirable between judicial institutions settling inter-state disputes; reinforced the judicial pronouncements of ITLOS; and most of all, facilitated the Parties in overcoming their differences by reinstating the need for greater co-operation and information exchange between them. Tanaka has opined, "[by] enhancing the ITLOS provisional measures, the Annex VII tribunal endorsed the interstate processes for notification and consultation as part of the procedural obligations under Part XII of [the LOSC]."

Churchill and Scott have suggested that as a result of the provisional measures prescribed by ITLOS and Annex VII arbitral tribunal, there is now improved co-operation between Ireland and the United Kingdom over the developments at MOX plant and other related matters. ${ }^{884}$ Therefore Ireland is more informed of what is going on in this regard, and would be better placed to attune its policies and strategies influencing oceans governance, according to recent developments if need be. Increased co-operation between the States has also kept the dispute under control and prevented it from escalating into a breach of peace.

\footnotetext{
Settlement Procedures" (2004) 17 LJIL 815; Campbell McLachlan "The Principle of Systemic Integration and Article 31 (3) (C) of the Vienna Convention" (2005) 54 ICLQ 279, 300.

${ }^{880}$ Churchill and Scott, above $\mathrm{n} 848,672$.

${ }^{881}$ Maki Tanaka, above n 868, 393.

${ }^{882}$ Churchill and Scott, above n 848, 672.

${ }^{883}$ Maki Tanaka, above n 868, 392.

${ }^{884}$ Churchill and Scott, above n 848, 675.
} 


\section{G The Case Concerning Land Reclamation by Singapore In and Around the Straits of Johor (Provisional Measures)}

On 4 July 2003, Malaysia instituted the Annex VII arbitration proceedings against Singapore seeking to settle a bilateral dispute. ${ }^{885}$ On 5 September 2003, Malaysia filed an Application before ITLOS requesting provisional measures under Article 290(5) of the Convention, pending the constitution of an arbitral tribunal. ${ }^{886}$ Though this dispute related to ocean space, it had its roots in the acute shortage of land space in Singapore. ${ }^{887}$

This case concerned certain land reclamation activities carried out by Singapore in alleged breach of its obligations under the Convention and that allegedly impinged upon Malaysia's rights in and around the Straits of Johor. ${ }^{888}$ Malaysia sought certain provisional measures based on concerns that primarily related the interference with the navigation and marine environmental degradation in the Straits of Johor. ${ }^{889}$ The Tribunal gave its Order on 8 October 2003, prescribing provisional measures. The unanimous judgment provided inter alia that a group of independent experts study and prepare reports on the effects of land reclamation activities carried out by Singapore and that the Parties continue to exchange information regularly to access the risks or effects of the land reclamation activity. ${ }^{890}$

What is noteworthy in this case is that ITLOS played a facilitative role in helping the two States overcome the stalemate in their negotiations. During the proceedings, Singapore had provided formal undertakings on three of the four provisional measures sought by Malaysia, and ITLOS in putting such assurances on judicial record had acted as a catalyst in helping the Parties reach agreement on the crucial issues. ${ }^{891}$ As Philippe Gautier has argued, "[t]he parties were able

\footnotetext{
885 Request for Provisional Measures of Malaysia (4 September 2003), available at $<$ http://www.itlos.org/> (last accessed 1 December 2005) para 9.

${ }^{886}$ Land Reclamation Case - Provisional Measures, above n 728.

${ }^{887}$ See Provisional Measure in International Law, above n 722, 216.

${ }^{888}$ Land Reclamation Case - Provisional Measures, above n 728, para 22.

${ }^{889}$ Request for Provisional Measures of Malaysia, para 5, above n 885.

${ }^{890}$ Land Reclamation Case - Provisional Measures, above n 728, paras 106(1)(a) and 106(1)(b).

${ }^{891}$ Klein, above n 265, 83.
} 
to narrow down their differences by entering into a series of commitments which were recorded by the Tribunal." 892 Further, the Tribunal recognised that under the particular circumstances of the case, the land reclamation works could have adverse effects on the marine environment and through the provisional measures, required the Parties to proceed with prudence and caution. ${ }^{893}$ In doing this, the Tribunal helped prevent any possible damage to the marine environment, by directing Singapore to restrain from conducting any land reclamation activities, taking into account the reports of the group of independent experts. ${ }^{894}$ Furthermore, as one commentator has noted, with the implied threat of prescribing measures not in line with the expectations of the parties, ITLOS persuaded the parties to agree on certain issues, which would not have been otherwise possible. ${ }^{895}$ Hence, it is argued that the Tribunal's judgment in this case, had a constructive impact on oceans governance.

\section{H The Case Concerning Land Reclamation by Singapore In and Around the Straits of Johor (Settlement Agreement and Award)}

The second phase of the dispute regarding land reclamation by Singapore in and around the Straits of Johor saw the composition of a five-member Annex VII arbitral tribunal that met on 10 January 2005 with the PCA serving as its registry. ${ }^{896}$ Malaysia and Singapore had, in the interim period of one year and three months between ITLOS's Order and the composition of the arbitral tribunal, made much progress in their negotiations. The Parties informed the tribunal that no action was expected of it for the time being since they had agreed on a draft Settlement Agreement. ${ }^{897}$

This dispute between Malaysia and Singapore was finally resolved on 26 April 2005 with a signing of a "Settlement Agreement in the Case Concerning

\footnotetext{
${ }^{892}$ Philippe Gautier "The International Tribunal for the Law of the Sea: Activities in 2003" (2004) 3 Chinese J Intl L 241, 263.

${ }^{893}$ Provisional Measure in International Law, above n 722, 217.

${ }^{894}$ Land Reclamation Case - Provisional Measures, above n 728, para 106(2).

${ }^{895}$ Klein, above n 265, 84.

${ }^{896}$ Permanent Court of Arbitration "Case Concerning Land Reclamation by Singapore In and Around the Straits of Johor" (14 January 2005) Press Release, available at $<$ http://www.pcacpa.org/> (last accessed 1 December 2005). The tribunal was composed of Mr M C W Pinto (President), Dr Kamal Hossain, Professor Bernard H. Oxman, Professor Ivan Shearer, and Sir Arthur Watts.

${ }^{897}$ Permanent Court of Arbitration Press Release, above n 896.
} 
Land Reclamation by Singapore In and Around the Straits of Johor" ${ }^{\prime 898}$ between the representatives of the respective Governments. ${ }^{899}$ The Agreement represents a fair and balanced outcome of the dispute reached by amicable means between the two States through a series of bilateral negotiations. ${ }^{900}$ Malaysia and Singapore went back and jointly applied to the Annex VII tribunal for the terms of the Agreement to constitute the final Award in the arbitration. ${ }^{901}$ The Annex VII tribunal issued the Award on 1 September 2005, on the terms agreed upon by the parties. ${ }^{902}$

In the author's opinion, all the dispute settlement mechanisms utilised in the settlement of this dispute played a predominantly facilitative role, fostering co-operation between the disputant Parties. In the proceedings before ITLOS, Malaysia contended that Singapore had failed to appreciate Malaysia's serious concerns about its land reclamation works. ${ }^{903}$ The negotiations between the Parties arguably played the biggest role in the actual resolution of the dispute. The provisional measures prescribed by the Tribunal played a big role in the oceans governance around the Straits of Johor. Overall, the availability and utilisation of both, ITLOS and the Annex VII tribunal, helped the Parties resolve their dispute and jointly concentrate on the good governance of the regional oceans. Thus the dispute settlement mechanisms of the LOSC played an important role in good oceans governance.

\footnotetext{
${ }^{898}$ Settlement Agreement in the Case Concerning Land Reclamation by Singapore In and Around the Straits of Johor, (26 April 2005), available at $<$ http://www.mfa.gov.sg/internet/press/land/Settlement_Agreement.pdfs (last accessed 8 December 2005) [Settlement Agreement - Malaysia and Singapore]. The Agreement was signed by Tan Sri Ahmad Fuzi Hj Abdul Razak and Professor Tommy Koh, the respective Agents of the Malaysian and Singapore Governments. The signing was witnessed by HE Dato' Seri Syed Hamid Albar, Minister of Foreign Affairs of Malaysia, and HE George Yeo, Minister for Foreign Affairs of Singapore.

${ }^{899}$ Ministry of Foreign Affairs of Singapore "Joint Press Statement on the Case concerning Land Reclamation by Singapore in and around the Straits of Johor" (26 April 2005) Press Release, available at $<$ http://www.mfa.gov.sg/internet/ $>$ (last accessed 1 December 2005).

${ }^{900}$ Ministry of Foreign Affairs of Singapore Press Release, above n 899.

${ }^{901}$ Ministry of Foreign Affairs of Singapore Press Release, above n 899.

902 Case Concerning Land Reclamation by Singapore In and Around the Straits of Johor (Malaysia $v$ Singapore) (2005), available at <http://www.pca-cpa.org/> (last accessed 1 December 2005) [Land Reclamation Arbitration].

${ }_{903}$ Nico Schrijver "Practising International Law at the International Tribunal for the Law of the Sea: The Case Concerning Land Reclamation in and Around the Straits of Johor (Malaysia v Singapore), Application for Provisional Measures” (2005) 6 (1) Griffin's View 35, 36.
} 
There has been some criticism of the Tribunal's limited development of the principles of international environmental law through the provisional measures cases. ${ }^{904}$ Nevertheless, in conclusion to the assessment of the provisional measures jurisprudence of the Tribunal, it is reiterated that overall it has made a constructive contribution to oceans governance. As Robin Churchill has put it so well in analysing the provisional measures cases at ITLOS: $:^{905}$

... there seems to be something of an interesting pattern emerging from these
cases. The mere fact of provisional measures being sought has seemingly
induced respondent States to be more conciliatory, and the ITLOS has followed
this up encouraging or ordering the parties to co-operate in various ways.
Because provisional measures prescribed by the ITLOS are binding and the
parties are ordered to report on their compliance with them, the parties must
take such measures seriously. Consequently, increased co-operation between
the parties has in fact resulted, reducing tension between them.

In reducing tension between the parties to the disputes and fostering a spirit of co-operation between the disputants, the Tribunal and even the Annex VII arbitral tribunals have actually facilitated international peace and security. This has in turn enabled the parties to the dispute to spend less effort on dispute management and concentrate their resources on advancing the cause of good oceans governance. Thus indirectly, the Tribunal and the Annex VII arbitral tribunals have made constructive contributions to oceans governance. Besides this, the dispute settlement bodies have also played a direct and constructive role in oceans governance by ordering disputants to proceed with prudence and caution, when threat to the marine environment, living as well as non-living, was imminent.

Further, these cases have proved that as in ordinary domestic law where interlocutory proceedings are often determinative, interim relief by way of provisional measures can often create good legal developments for oceans governance by averting later conflicts. Even where decisions have not granted the applicants' requests, the rulings have nonetheless provided good guidance for the future.

\footnotetext{
${ }^{904}$ Gwenaele Rashbrooke "The International Tribunal for the Law of the Sea: A Forum for the Development of Principles of International Environmental Law?" (2004) 19 (4) IJMCL 515, 535. 905 Robin Churchill "The International Tribunal for the Law of the Sea: Survey for 2003" (2004) 19 (4) IJMCL 369, 379.
} 
After having discussed the disputes that saw the invocation of Part XV of the Convention, and resulted in their final settlement, the following paragraphs shall be devoted to briefly record the disputes to which a determination has not been reached yet. To the author's knowledge, there are presently at least three cases that have triggered the dispute settlement mechanisms of the Convention, which are pending final outcomes or have been suspended.

\section{A The Case concerning the Conservation and Sustainable Exploitation of Swordfish Stocks in the South-Eastern Pacific Ocean}

The dispute in the Case concerning the Conservation and Sustainable Exploitation of Swordfish Stocks in the South-Eastern Pacific Ocean (Swordfish Case) led to the creation of a Special Chamber of ITLOS on 20 December 2000, after an agreement between Chile and the EC. ${ }^{906}$ This was the first dispute under the LOSC that involved an international organisation, the EC, which is a party to the Convention. ${ }^{907}$ The dispute concerns the exploitation of Swordfish (Xiphias gladius) stocks in the South Pacific and dates back to the early $1990 \mathrm{~s} .{ }^{908}$ The dispute arose out of Chile's unilateral extension of Swordfish conservation measures in the high seas beyond its EEZ, and the prohibition on EC vessels from landing their catches in Chilean ports in contravention of such measures. ${ }^{909}$

\footnotetext{
906 Case concerning the Conservation and Sustainable Exploitation of Swordfish Stocks in the South-Eastern Pacific Ocean (Chile/ European Community) Order 2000/3 of 20 December 2000, available at $<\mathrm{http}: / / \mathrm{www}$.itlos.org/> (last accessed 20 December 2005) para 3.

${ }^{907}$ For some perspectives on the problems resulting from the admittance of international organisations as parties to cases, see Tullio Treves "International Organisations as Parties to Contentious Cases: Selected Cases" in Laurence Boisson de Chazournes, Cesare P R Romano and Ruth Mackenzie (eds) International Organizations and International Dispute Settlement: Trends and Prospects (Transnational Publishers Inc, Ardsley, New York, 2002) 37, 39.

${ }^{908}$ For a detailed history and discussion on the dispute, see Marcos A Orellana "The Swordfish Dispute between the EU and Chile at the ITLOS and the WTO" (2002) 71 Nordic J Intl L 55 ["The Swordfish Dispute between the EU and Chile at the ITLOS and the WTO"]. See also NonFlag State Enforcement in the High Seas Fisheries, above n 350, 315 - 323. For a history of Chile's concerns over fishing in the South Pacific, see Paul Stanton Kibel "Alone at Sea: Chile's Presencial Ocean Policy" (2000) 12 (1) J Envtl L 43.

909 "The Future of Compulsory Dispute Settlement Under the Law of the Sea Convention", above n 26, 702 .
} 
For the purposes of this thesis, it is interesting to note that in April 2000, the EC had taken the dispute to the WTO under the WTO Understanding on Rules and Procedures Governing the Settlement of Disputes. ${ }^{910}$ This gave rise to a possibility of potentially inconsistent or contradictory decisions emerging from the two bodies on the same dispute. ${ }^{911}$ It has been argued elsewhere that the Swordfish Case has a striking resemblance to the previously disputed Tuna/ Dolphin I\& II ${ }^{912}$ and Shrimp/ Turtle Cases ${ }^{913}$ before the WTO. ${ }^{914}$

The Swordfish Case can be seen as a classic case of forum shopping where the choice of a dispute settlement body by the respective parties was conveniently governed by their expected outcomes. The forums being fundamentally different - the WTO as a champion of free trade having a tradecentric outlook, while ITLOS as arguably an advocate for conservation under the relatively pro-environment Convention, ${ }^{915}$ the $\mathrm{EC}$ and Chile possibly wanted the dispute to be handled by the WTO and ITLOS respectively, guided by their own prospects of "winning." The global attention that this case has received also mirrors the difficulties encountered in reconciling trade and environment in international law, which has been the subject of many commentaries and debates. ${ }^{916}$ The competing jurisdictions of the two dispute settlement bodies

910 Chile - Measures Affecting the Transit and Importation of Swordfish - Request for Consultations by the European Communities (26 April 2000) WT/DS193/1.

911 "The Swordfish Dispute between the EU and Chile at the ITLOS and the WTO", above n 908, 55.

912 See United States - Restrictions on Imports of Tuna (US - EU Dispute) - Report of the GATT Panel (20 May 1994) DS29/R; (1994) 33 ILM 842.

${ }^{913}$ See United States - Import Prohibition of Certain Shrimp and Shrimp Products - Report of the Appellate Body (12 October 1998) WT/DS58/AB/R; (1999) 38 ILM 118.

914 John Shamsey "ITLOS vs Goliath: The International Tribunal for the Law of the Sea Stands Tall with the Appellate Body in the Chilean - EU Swordfish Dispute" (2002) 12 Trans Natl L \& Contemp Probs 513, 528 .

${ }^{915}$ Shamsey, above n 914, 540.

916 See J A Peters "How to Reconcile Trade and Environment" in Wybo P Heere (ed) International Law and The Hague's 750th Anniversary (TMC Asser Press, The Hague, 1999) 309; Gerhard Loibl "Trade and Environment - A Difficult Relationship New Approaches and Trends: The Kyoto Protocol and Beyond" in Gerhard Hafner and others (eds) Liber Amicorum Professor Seidl-Hohenveldern - In Honour of His 80th Birthday (Kluwer Law International, The Hague, 1998) 419; Winfried Lang "Trade and Positive Measures in Multilateral Environmental Agreements: Effectiveness and Suitability" in Wybo P Heere (ed) International Law and The Hague's 750th Anniversary (TMC Asser Press, The Hague, 1999) 317; Lakshman Guruswamy "The Promise of the United Nations Convention on the Law of the Sea (UNCLOS): Justice in Trade and Environment Disputes" (1998) 25 Ecology L Q 189; Ian J Popick "Are There Really Plenty of Fish in the Sea? The World Trade Organization's Presence is Effectively Frustrating the International Community's Attempts to Conserve the Chilean Sea Bass" (2001) 50 Emory LJ 939; J Hertin, Ian C Scoones and Frans Berkhout "Can Environmental and Trade Objectives be Better Integrated?" in Who Governs the Global Environment? (The Economic and Social Research 
involved in this case, has led to some commentators calling the Swordfish Case a dispute between the law of the sea and trade. ${ }^{917}$

Later during March - April 2001, the EC and Chile sent request to the WTO $^{918}$ and ITLOS $^{919}$ requesting the dispute settlement bodies to suspend the proceedings, on the ground that they had reached a provisional agreement in respect of the dispute. ${ }^{920}$ From the perspective of the LOSC, the dispute has been suspended for two consecutive times thereafter and the present extension of time limits for the proceedings extends to 1 December $2008 .{ }^{921}$ It would be interesting to see the outcomes of this dispute from the perspective of oceans governance should it be revived again, but in the opinion of the author chances for such revival are weak.

\section{B Dispute Concerning the Delimitation of the Exclusive Economic Zone and Continental Shelf Between Barbados and the Republic Of Trinidad and Tobago}

This dispute concerns the delimitation of the EEZ and continental shelf between Barbados on one side and Trinidad and Tobago on the other. On 16 February 2005, Barbados initiated proceedings under Article 287 of the Convention for submission of the present dispute to an Annex VII arbitral

Council, Swindon, 2000), available at $<$ http://www.gecko.ac.uk/governance.pdf $>$ (last accessed 11 November 2005) 14.

${ }^{917}$ Peter-Tobias Stoll and Silja Vöneky "The Swordfish Case: Law of the Sea v Trade" (2002) 62 (1-2) ZaöRV 21. See also Markus Rau "Comment: The Swordfish Case: Law of the Sea v Trade" (2002) 62 (1-2) ZaöRV 37.

${ }_{918}$ WT/DS193/3, 6 April 2001 and WT/DS193/3/Add.1, 9 April 2001.

919 Case concerning the Conservation and Sustainable Exploitation of Swordfish Stocks in the South-Eastern Pacific Ocean (Chile/ European Community) Order 2001/1 of 15 March 2001, available at $<\mathrm{http}: / / \mathrm{www}$.itlos.org/> (last accessed 20 December 2005).

${ }^{920}$ Lesley Murphy "EC and Chile Reach Agreement on 10-year Swordfish Dispute" (2001) 4 IntFish Bulletin, available at <http://www.oceanlaw.net/bulletin/sample/focus/0102c.htm $>$ (last accessed 20 December 2005); Marcos A Orellana "The EU and Chile Suspend the Swordfish Case Proceedings at the WTO and the International Tribunal of the Law of the Sea" (2001) 60 ASIL Insights, available at <http://www.asil.org/insights/insigh60.htm> (last accessed 20 December 2005).

${ }_{921}$ Case concerning the Conservation and Sustainable Exploitation of Swordfish Stocks in the South-Eastern Pacific Ocean (Chile/ European Community) Order 2003/2 of 16 December 2003 $<$ http://www.itlos.org/> (last accessed 20 December 2005); Case concerning the Conservation and Sustainable Exploitation of Swordfish Stocks in the South-Eastern Pacific Ocean (Chile/ European Community) Order 2005/1 of 29 December 2005, available at <http://www.itlos.org/> (last accessed 20 December 2005). 
tribunal. ${ }^{922}$ The dispute relates to certain fishing activities carried out by the Barbadians to the north of the territorial sea around the island of Tobago on the basis of historic fishing rights as maintained by Barbados. ${ }^{923}$

The PCA is acting as the Registry for the case, and by agreement between the two Governments, all proceedings of the arbitration are confidential. ${ }^{924}$ The oral proceedings were conducted in London at the International Dispute Resolution Centre from 17 - 28 October $2005 .{ }^{925}$ The tribunal is currently deliberating about its Award, which will probably be made public after it has been rendered. ${ }^{926}$ This is the fourth time an Annex VII arbitral tribunal under the Convention has been constituted to deal with the merits of an oceans dispute. The case is also quite significant since it is the first maritime delimitation case that has been brought to a dispute settlement body under the LOSC.

\section{Dispute Concerning the Delimitation of the Maritime Boundary Between Guyana and Suriname}

This case is a result of a border dispute between the two adjacent coastal states of Guyana and Suriname, which was aggravated in June 2000 when Suriname forcibly evicted a Guyanese oil platform from the disputed area. ${ }^{927}$ The disputed area is a maritime boundary, which extends through the territorial sea, EEZ and continental shelf of the parties in question. ${ }^{928}$ The uncertainty over the boundary dates back to a time when both the South American nations had yet not gained their independence from colonialism. ${ }^{929}$ On the brink of hostility and a

\footnotetext{
${ }^{922}$ See Rules of Procedure for the Tribunal Constituted Under Annex VII to the United Nations Convention on the Law of the Sea Pursuant to the Notification of Barbados Dated 16 February 2005, available at $<$ http://www.pca-cpa.org/> (last accessed 10 January 2006).

${ }_{923}$ Report of the Secretary-General on Oceans and Law of the Sea, $59^{\text {th }}$ Session, 4 March 2004, UN Doc A/59/62, para 38 .

${ }^{924}$ Barbados/ Trinidad and Tobago, available at $<$ http://www.pca-cpa.org/> (last accessed 10 January 2006).

${ }^{925}$ Barbados/ Trinidad and Tobago, above $\mathrm{n} 924$.

${ }^{926}$ Barbados/ Trinidad and Tobago, above n 924.

927 Miranda La Rose "Guyana, Suriname Maritime Boundary Dispute" (10 January 2006) Stabroek News, available at <http://www.stabroeknews.com> (last accessed 10 January 2006).

${ }_{928}$ Thomas W Donovan "Guyana Invokes Annex VII of the United Nations Convention on the Law of the Sea Against Suriname for Disputed Maritime Boundary" (2004) ASIL Insights, available at $<$ http://www.asil.org/insights/insigh131.htm $>$ (last accessed 10 January 2006).

${ }^{929}$ See Thomas W Donovan "Suriname-Guyana Maritime and Territorial Disputes: A Legal and Historical Analysis" (2003) Florida State J Transnational Law \& Policy 41, 42. See also Thomas W Donovan "Challenges to the Territorial Integrity of Guyana: A Legal Analysis" (2004) 32 Ga J Intl \& Comp L 661.
} 
diplomatic impasse, Guyana referred the dispute to an Annex VII arbitral tribunal on 24 February $2004 .{ }^{930}$

The PCA is acting as the Registry in this case, and as with the Barbados/ Trinidad and Tobago dispute, the proceedings in this dispute too happen to be confidential and no further information on the developments is available at the time of this writing. ${ }^{931}$ This Award in this case, when it is rendered, should hopefully demonstrate a positive and significant influence on oceans governance, along the lines of the potential for contribution as discussed in chapter 2 .

\title{
V SPEEDY JUSTICE
}

Quite understandably, the Tribunal places a lot of importance on dealing with prompt release applications before it. The Rules of the Tribunal along with the complementary texts of the Resolution on internal judicial practice and the Guidelines on the preparation and presentation of cases clearly signal the policy of the Tribunal with regard to expeditious proceedings before it, under relatively strict time limits. ${ }^{932}$ Article 112(1) of the Rules of the Tribunal provides: ${ }^{933}$

\begin{abstract}
The Tribunal shall give priority to applications for release of vessels or crews over all other proceedings before the Tribunal. However, if the Tribunal is seized of an application for release of a vessel or its crew and of a request for the prescription of provisional measures, it shall take the necessary measures to ensure that both the application and the request are dealt with without delay.
\end{abstract}

As is clear from the above provision, the Tribunal assigns the highest importance to the disposal of prompt release cases before it, as against any other. Even envisaging a situation where the Tribunal is faced with a provisional measures case, the Tribunal commits itself to deal with both without delay to the best of its abilities. Such commitment on the part of the Tribunal is commendable

\footnotetext{
${ }^{930}$ Ministry of Foreign Affairs of the Republic of Guyana "Brief Summary of Guyana-Suriname Relations", available at <http://www.minfor.gov.gy/relations/suriname.php $>$ (last accessed 10 January 2006).

${ }_{931}$ Guyana/ Suriname, available at $<$ http://www.pca-cpa.org/> (last accessed 10 January 2006).

${ }^{932}$ See Tullio Treves "The Procedure before the International Tribunal for the Law of the Sea: The Rules of the Tribunal and Related Documents" (1998) 11 LJIL 565; Philippe Gautier "Interim Measures of Protection Before the International Tribunal for the Law of the Sea" in M H Nordquist and J N Moore (eds) Current Marine Environmental Issues and the International Tribunal for the Law of the Sea (Kluwer Law International, The Hague, 2001) 243, 251.

${ }_{933}$ Rules of International Tribunal for the Law of the Sea $<$ http://www.itlos.org/> (last accessed 1 December 2005), art 112 (1).
} 
and deserves praise in the light of its practice since inception. One of the most significant aspects of the functioning of the Tribunal has perhaps been the expediency with which it has handled the cases before it, especially the ones involving the prompt release of vessels. As one commentator has written - "[a] salutary feature of its jurisprudence is the deliberate speed with which its delivers its decisions." 934 Or as a news agency reports, that going "by international judicial standards" the Tribunal delivers its judgment at "lightning speed."935

The Tribunal could in this regard be seen as an answer to the call sounded by Sir Cecil Hurst in 1925 for an "International Court of Piepowder", dispensing speedy justice in minor international disputes. ${ }^{936}$ Hurst advocated for such courts of piepowder in the international arena that would bring expeditious relief to aggrieved individuals in cases of little political importance such as those involving simple questions as to "whether a particular fishing vessel was arrested within or without the limits of territorial waters." 937

The adage - "justice delayed is justice denied" is extremely relevant in prompt release cases. The Tribunal has stressed the importance that it places on the elementary considerations of humanity and due process of law. ${ }^{938}$ ITLOS has successfully proved by its swift actions in delivering expedited prompt release judgments that it takes the responsibilities reposed on it by the Convention, very seriously.

\footnotetext{
${ }^{934}$ Howard S Schiffman "UNCLOS and Marine Wildlife Disputes: Big Splash or Barely a Ripple?" (2001) 4 JIWLP 257, 277 [“UNCLOS and Marine Wildlife Disputes: Big Splash or Barely a Ripple?"].

${ }^{935}$ Carsten Hoefer "International Sea Court to Calm the World's Stormy Seas" December 4, 1997 Deutsche Presse-Agentur.

${ }^{936}$ See generally Renate Platzöder "Impact of Arbitration Established under Annex VII on the Implementation of the Law of the Sea Convention" in Davor Vidas and Willy Østreng (eds) Order for the Oceans at the Turn of the Century (Kluwer Law International, The Hague, 1999) $105,106$.

${ }^{937}$ Cecil J B Hurst "Wanted! An International Court of Piepowder" (1925) 6 BYIL 61. The name 'piepowder' was a corruption of the French expression 'pied poudre'. Such courts of piepowder exercised jurisdiction over petty disputes arising in fairs and markets in England, which though happened to be the lowest courts of justice were the most expeditious. Hurst opined, whether the name 'piepowder' signified that justice there was so speedy that litigants had no time to brush the dust off their feet or whether it was so coined because the courts would entertain wayfarers wandering from market to market, is of little significance. What he felt important was for modern day governments to replicate such courts that would deal expeditiously with many of the nonpolitical matters that arise time and again in the increasing international relations between Nations of the present day.

${ }^{938}$ The “Juno Trader” Judgment, above n 636, para 77.
} 
In all the prompt releases cases that ITLOS has rendered a judgment, the maximum time it has taken to do so has been a period of 30 days from the date of the Application as can be seen in TABLE - II. 
TABLE - II TIME TAKEN BY ITLOS IN DISPOSING URGENT CASES

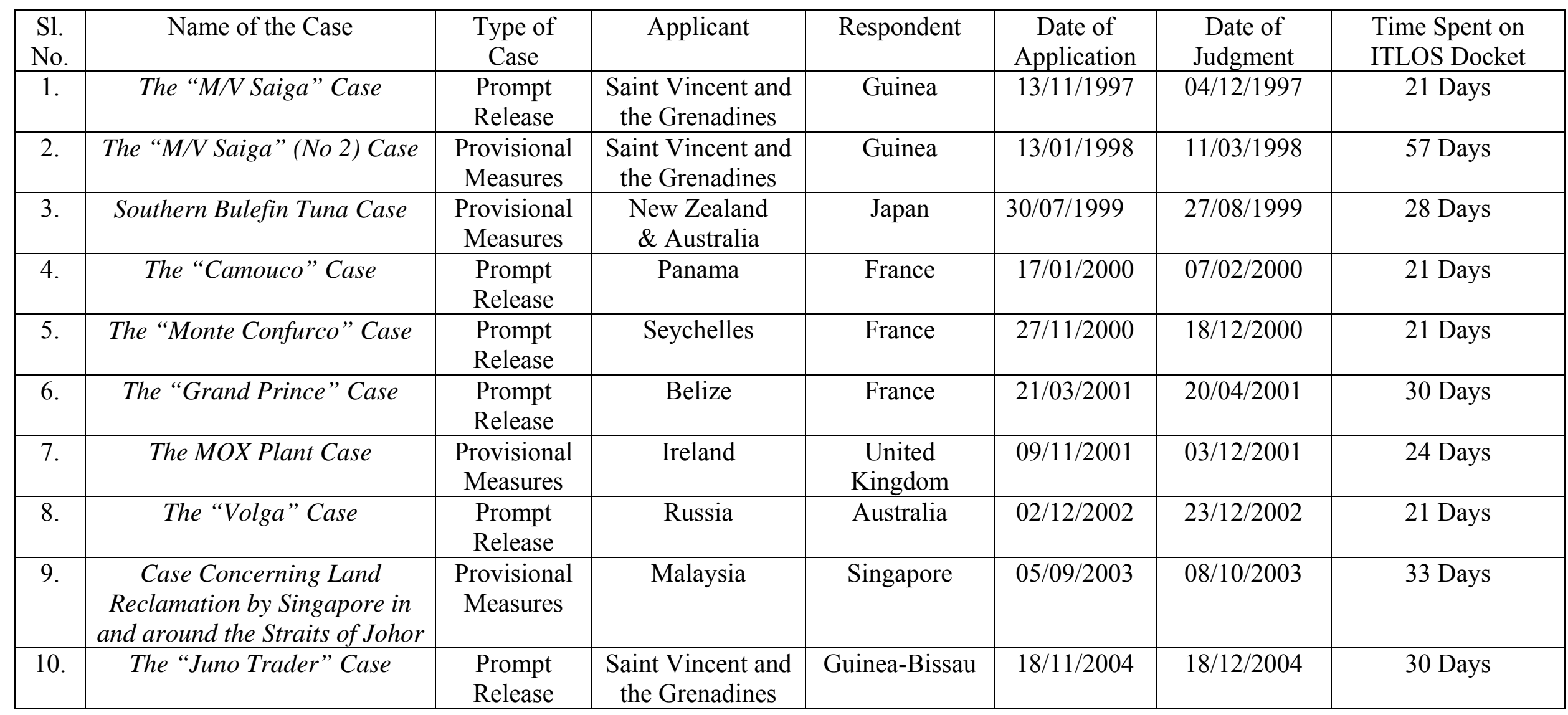


In this regard, it is necessary to include the "Grand Prince" Case in the assessment as although ITLOS provided no relief in this case in the form of a reasonable bond, it did deliver a reasoned judgment. ${ }^{939}$ It is clear from a cursory glance at TABLE - II that it was only in the "Grand Prince" Case and the "Juno Trader" Case, that the Tribunal took 30 days to deliver a judgment. Apart from the exception noticed in these two cases, the Tribunal has successfully fulfilled its commitment to accord utmost priority to prompt release cases.

Even the provisional measures cases were dealt with in 57, 28, 24 and 33 days $^{940}$ respectively, and such expedited judgments obviously required "Herculean efforts by the judges and the entire staff of the Registry.", Therefore the commendations that ITLOS has earned "from representatives of States parties to the Convention, scholars, agents, and practitioners of international litigation" are all well deserved. ${ }^{942}$ Speedy disposal of cases, it is submitted, bodes well for the future utilisation of ITLOS, ${ }^{943}$ besides having a beneficial impact on oceans governance.

\section{CONCLUSIONS}

The chapter began with an account of the dispute settlement provisions under Part XV of the LOSC. In part II of the chapter, the discussion was moved to the prompt release jurisprudence generated so far under Part XV and this identified the Tribunal's habit of significantly discounting bonds sought for vessel release. Some inconsistency was noticed in the Tribunal's consideration of the proceeds of the catch in the assessment of bonds. It was seen that the discounting of bonds was leading to indirect encouragement to IUU fishing

\footnotetext{
939 For some critical commentary on the case, see Bernard Oxman and Vincent P Bantz "The 'Grand Prince' (Belize v. France)" (2002) 96 AJIL 219; D J Devine "Short - Circuiting the Right to Prompt Release" (2003) 28 SAYIL 300.

${ }^{940}$ The M/V Saiga (No 2) Case, the Southern Bluefin Tuna Cases, The MOX Plant Case and the Case Concerning Land Reclamation by Singapore In and Around the Straits of Johor.

941 "Deliberations, Judgments, and Separate Opinions in the Practice of the International Tribunal for the Law of the Sea", above n 536, 63.

942 Joseph Akl "Question of Time-Limits in Urgent Proceedings before the Tribunal" in M H Nordquist and J N Moore (eds) Current Marine Environmental Issues and the International Tribunal for the Law of the Sea (Kluwer Law International, The Hague, 2001) 75, 77.

${ }_{943}$ Ted L McDorman "An Overview of International Fisheries Disputes and the International Tribunal for the Law of the Sea" (2002) 40 Can YIL 119, 146.
} 
operations and uncertainty among coastal states about the determination of reasonable bonds. This is no doubt an undesirable development and can have destructive implications for oceans governance.

In part III of the chapter, the analysis of the provisional measures cases and subsequent judicial proceedings revealed a largely constructive impact on oceans governance. By encouraging the disputant states to co-operate and engage in greater dialogue with each other in working towards a final settlement of the dispute, the dispute settlement mechanisms have promoted international peace and security and contributed to good governance of the oceans. Part IV gave a brief account of the disputes pending resolution under the dispute settlement provisions of the Convention. Part $\mathrm{V}$ was devoted to acknowledging the expeditious handling of cases by ITLOS as a laudable aspect in its constructive role in oceans governance.

Overall, it is fair to conclude that the jurisprudence under Part XV to date has been essentially constructive. Analysing the Tribunal's jurisprudence Christoph Schwarte concludes: ${ }^{944}$

\begin{abstract}
Although the Tribunal is expected to resolve the grey areas in [the LOSC], it often seems to avoid clear pronouncements on substantial legal questions, while settling for compromise formulas. What has been described as a benefit to ITLOS, in that its members are among the most prominent drafters and negotiators of [the LOSC], may actually result in an impediment to the elaboration and interpretation of the Convention's provisions...Although the jurisprudence of ITLOS has acknowledged the importance of environmental concerns, it has not yet released the full potential of [the LOSC] for the protection of the marine and coastal environment.
\end{abstract}

This author concurs with the above conclusions of Schwarte and adds that ITLOS should be better placed to develop its full potential under the Convention when states bring cases before it on merits. Prompt release and provisional measures orders are merely intended to provide interim relief and therefore do not deal with the details of the dispute that are necessarily reserved for the merits phases of dispute settlement. Being interlocutory in nature, such cases do not influence state policy and action to as great an extent as a major case on merits. Therefore orders of prompt release and provisional measures are relatively less pervasive, and though their impact has been largely constructive they have not

944 Christoph Schwarte "Environmental Concerns in the Adjudication of the International Tribunal for the Law of the Sea" (2004) 16 Geo Intl Envtl L Rev 421, 438. 
been equally significant for oceans governance. Hence, the destructive elements of the Part XV jurisprudence to date have not caused much real harm to oceans governance. It can be hoped that the future will see states utilise Part XV to a greater extent so as to enable dispute settlement mechanisms to have a real and strong impact on oceans governance that is expectantly constructive. 


\section{CHAPTER 4}

\section{THE INTERNATIONAL TRIBUNAL FOR THE LAW OF THE SEA AND DEVELOPING COUNTRIES}

The aim of this chapter in the overall scheme of the present thesis is based on the findings in part IV of chapter 2. It was shown in chapter 2 that dispute settlement under the LOSC can potentially play an important role in oceans governance. This chapter reveals that developing countries are being able to engage with ITLOS at various levels, which provides overall encouragement to them to use the dispute settlement procedures in times of need. The central argument of this chapter is that by increasing participation of developing countries in the dispute settlement process, opportunities for dispute settlement to play a role in oceans governance is greatly enlarged.

As a permanent international judicial body, ITLOS can easily be designated as the natural candidate for the playing the paramount role of maintaining world peace and sustainable development of marine resources ${ }^{945}$ through the consistent interpretation of the LOSC. ${ }^{946}$ It is also "an institutional mechanism for the stability, integrity and viability of the international legal order over the seas and oceans" 947 set up by the Convention. Hence in the context of global oceans governance, it may be fairly stated that ITLOS commands an important position or has the potential to do so as against the other institutions functioning in the area of the law of the sea.

\footnotetext{
${ }^{945}$ For a discussion on the provisions in the LOSC dealing with marine resource management, see Martin B Tsamenyi "Mechanisms for Integrated Resource Management" in Mochtar Kusuma Atmadja, Thomas A Mensah and Bernard H Oxman (eds) Sustainable Development and Preservation of the Oceans: The Challenges of UNCLOS and Agenda 21 (The Law of the Sea Institute, University of Hawaii, Honolulu, 1997) 414, 416.

946 “The Settlement of Disputes under LOSC - How Entangled Can We Get?", above n 372, 90. On the jurisdiction of ITLOS, see Tullio Treves "The Law of the Sea Tribunal: Its Status and Scope of Jurisdiction after November 16, 1994" (1995) 55/2 ZaöRV 421; Hugo Caminos "The Jurisdiction of the International Tribunal for the Law of the Sea: An Overview" in Myron H Nordquist and John Norton Moore (eds) Oceans Policy: New Institutions, Challenges and Opportunities (Kluwer Law International, The Hague, 1999) 93; Thomas A Mensah "The International Tribunal for the Law of the Sea: The First Year" in Myron H Nordquist and John Norton Moore (eds) Oceans Policy: New Institutions, Challenges and Opportunities (Kluwer Law International, The Hague, 1999) 73, 73.

947 "The International Tribunal for the Law of the Sea and the Comprehensive Dispute Settlement System of the Law of the Sea", above n 253, 37.
} 
On the same point of oceans governance, it is noteworthy that a large part of the world is constituted by what are designated as 'developing countries'. These countries, with the exception of landlocked developing countries, also control and use vast areas of the world's ocean space. Such control is mostly by means of their territorial seas, contiguous zones and exclusive economic zones. ${ }^{948}$ The 'use' of course extends to the high seas of the world too, through activities like fishing, navigation and shipping. Therefore, taking all these factors into consideration, it is fair to surmise that developing countries ultimately end up accessing vast ocean tracts. Developing countries, often reeling under lack of resources - human and financial, face many challenges in the path of sustainable oceans governance. ${ }^{949}$ Generally speaking, for them sustainable oceans governance is really a question of capacity more than anything else. ${ }^{950}$ Even when the political will exists to implement laws directed at oceans governance, little may be forthcoming in their actual efforts due to the resource challenges they face.

It shall be shown in this chapter that ITLOS is doing its own bit in helping developing countries empower themselves in order that they are able to do a better job in oceans governance. It should be acknowledged that such benevolent service provided or supported by the Tribunal goes beyond the ordinary mandate of international courts and tribunals and represents an ongoing positive development at an international level. To say the least, such relationship building between international judicial bodies and countries can go a long way in bolstering the confidence of states to utilise them for dispute settlement. For developing countries in particular, such measures and opportunities even help in

\footnotetext{
${ }^{948}$ Taking the case of fisheries, about 64 per cent of the world's fish are caught off the coastal areas of developing countries. See David M Dzidzornu "Coastal State Obligations and Powers Respecting EEZ Environmental Protection Under Part XII of the UNCLOS: A Descriptive Analysis" (1997) 8 Colo J Intl Envtl L \& Poly 283, 287. Also see the latest FAO Yearbook of Fisheries Statistics of 2003. Summary table 'Capture production by principal producers in 2003' lists China, Peru, Indonesia, India, Chile, Russian Federation, Thailand, Philippines, Vietnam, Mexico, Myanmar, Malaysia, and Bangladesh among the top 20 fish producers of the world. This means that a significantly high volume of the total fish caught in the world are caught by developing countries. $<\mathrm{http} / / / \mathrm{www}$. fao.org/fi/default_all.asp $>$ (last accessed 1 December 2005).

${ }^{949}$ For example, the impediments along the way of developing countries in fisheries research has been pointed out in G L Kesteven "Fisheries Research in Developing Countries" in Brian J Rothschild (ed) Global Fisheries: Perspectives for the 1980s (Springer-Verlag, New York, 1983) 247, 256. See also Hinds, above n 340, 354.

950 See David Leary and Anshuman Chakraborty and "New Horizons in the Law of the Sea" (2005) 36 VUWLR 675, 677.
} 
capacity building over a period of time, and translates into good oceans governance.

It can be said that, given all other necessary conditions, oceans governance and national development are directly proportional to each other; higher the level of development of a country, higher is the level of oceans governance initiatives it is able to carry out. ${ }^{951}$ From another angle, not only do developing countries influence oceans to a significant degree but also are prone to be affected more by its various changes. It has been argued elsewhere that, the rapidly increasing populations in developing countries would feel the strongest impacts arising from global oceanic phenomena such as sea-level rise and changes in ocean circulation. ${ }^{952}$

Therefore in the larger picture of global oceans governance, it could be said that both ITLOS as well as developing countries have vital roles to play. Hence, this forms the basic justification for choosing ITLOS and developing countries for the study. Also noteworthy in this regard, is the active role that developing countries played not only in the establishment of ITLOS but also in the adoption of the LOSC as a whole. ${ }^{953}$ Indeed, the developing countries struggled hard for the replacement of the old law of the sea that served the interests of colonialism, imperialism and maritime hegemony by the LOSC. ${ }^{954}$ No wonder the LOSC makes special reference to developing countries in many of its provisions. ${ }^{955}$

The present chapter begins with a definition of developing countries for the purpose of the study. The next section is devoted to looking at the ways in which developing countries are enabled to overcome some of the constraints with

\footnotetext{
${ }^{951}$ For a different perspective on oceans governance and development concerning the oceans, see Ruben P Mendez "Ocean Governance: The Question of Financing" in Peter Bautista Payoyo (ed) Ocean Governance: Sustainable Development of the Seas (United Nations University Press, Tokyo, 1994) 309.

952 Sustainable Ocean Governance, above n 71, 227.

${ }^{953}$ See generally Nasila S Rembe Africa and the International Law of the Sea: A Study of the Contribution of the African States to the Third United Nations Conference on The Law of the Sea (Sijthoff \& Noordhoff, Alphen aan den Rijn (The Netherlands), 1980); Karin Hjertonsson The New Law of the Sea: Influence of the Latin American States on Recent Developments of the Law of the Sea (A W Sijthoff, Leiden, 1973). See also A O Adede "Law of the Sea - Developing Countries' Contribution to the Development of Institutional Arrangements for the International Sea-Bed Authority" (1977) 4 Brook J Intl L 1.

${ }^{954}$ Gurdip Singh United Nations Convention on the Law of the Sea Dispute Settlement Mechanisms (Academic Publications, New Delhi, 1985) 3.

${ }^{955}$ For example, LOSC arts 61(3), 62, 70, 82, 119, 140, 143, 144, 148, 150(h), 151(10), 155, 173, 202, 203, 207, 244, 266, 268, 271, 272, 273, 274, 275 and 276.
} 
respect to dispute settlement particularly at the ITLOS. This section also highlights some of the areas in which developing countries continue to participate in and contribute to ITLOS. The chapter concludes with the comment that, though many avenues of cooperation and mutual exchange are currently open between ITLOS and developing countries, there exists room for further growth and development - all leading to good oceans governance.

\section{DEFINING DEVELOPING COUNTRIES}

At the outset, it must be acknowledged that it is not easy to determine which countries fall in the category of 'developing countries.' Hence it is useful to seek the definition of a 'developing country' and understand the criteria that qualify them to be so. The definition of a 'developing country' as found in a dictionary is "a poor or undeveloped country that is becoming more advanced economically and socially." 956 This definition obviously is not articulate or exhaustive enough to convey a proper meaning about developing countries, let alone help in identifying them. The term 'developing country' is synonymous with a number of other terms such as 'less-developed', 'underdeveloped', 'Third World', 'Group of 77,957 and even 'the South'. These terms are often used interchangeably and refer to the countries of Africa, Asia and Latin America that have been known to lag behind the 'West', 'North', 'First World', 'industrialised' and 'developed countries'. 958

Developing countries have been referred to as less developed countries and a subset of that group has been labelled as newly industrialised countries comprising the four Asian "dragons" or "tigers" of Korea, Hong Kong, Taiwan

\footnotetext{
${ }^{956}$ The Concise Oxford Dictionary of Current English (9 ed, Oxford University Press, Oxford, 1995).

957 The Group of 77 (G-77) was established on 15 June 1964 by seventy-seven developing countries as signatories to the "Joint Declaration of the Seventy-Seven Countries" issued at the end of the first session of the United Nations Conference on Trade and Development (UNCTAD) in Geneva. Although the membership of the G-77 has increased to 132 countries, the original name was retained because of its historic significance. See The Group of 77 $<$ http://www.g77.org/> (last accessed 4 February 2005).

${ }^{958}$ Karin Mickelson "Rhetoric and Rage: Third World Voices in International Legal Discourse" (1998) 16 Wis Intl L J 353, 356.
} 
and Singapore. ${ }^{959}$ It has been suggested that the issue of categorisation of these countries that lag behind the developed countries on points of economic and social development is as scientific as it is political. ${ }^{960}$ Furthermore, various institutions have categorised these developing countries in different ways and there is no absolute uniformity in such identification.

Speaking in terms of development, writers prefer the World Bank's definition of developing countries. ${ }^{961}$

\begin{abstract}
A developing country typically is one where people live on far less money and often lack basic public services - than those in highly - industrialized countries. Five out of the world's six billion people live in developing countries, where incomes are usually well under $\$ 1000$ a year.
\end{abstract}

In the GATT-WTO system, there has been no formal definition of the term 'developing country'. At the same time, GATT Article XVIII refers to a developing country as a country "whose economy 'can support low standards of living and [is] in the early stages of development." 962 Again, developing countries are divided into two groups - "developing counties" 963 and "least developed countries" "964 under the GATT-WTO system. However, since countries joining the WTO as developing countries do so purely on the basis of

\footnotetext{
${ }^{959}$ Kevin Kennedy "Preferential Treatment of Developing Countries" in Raj Bhala and Kevin Kennedy World Trade Law: The GATT-WTO System, Regional Arrangements and US Law (Lexis Law Publishing, Charlottesville, Virginia, 1999) 339, 339.

960 Cesare P R Romano "International Justice and Developing Countries: A Quantitative Analysis" (2002) 1 LPICT 367, 376. ["International Justice and Developing Countries"]. For a detailed historical study on the engagement of developing countries in international law, see Ram Prakash Anand International Law and the Developing Countries: Confrontation or Cooperation? (Martinus Nijhoff Publishers, Dordrecht, 1987). See also Wang Tieya "The Third World and International Law" in R St J Macdonald and Douglas M Johnston (eds) The Structure and Process of International Law: Essays in Legal Philosophy Doctrine and Theory (Martinus Nijhoff Publishers, The Hague, 1983) 955.

${ }^{961}$ See Stephan Ohlhoff \& Hannes L Schloemann "Rational Allocation of Disputes and 'Constitutionalisation': Forum Choice as an Issue of Competence" James Cameron \& Karen Campbell (eds) Dispute Resolution in the World Trade Organisation (Cameron May, London, 1998) 302 cited in James Gathii "Fairness As Fidelity to Making the WTO Fully Responsive to All its Members" in Is the International Trade Regime Fair to Developing States? (2003) 97 Am Socy Intl L Proc 153, 159. The World Bank FAQs "About Development" $<$ http://www.worldbank.org/faqs $>$ (last accessed 2 December 2005).

962 "Preferential Treatment of Developing Countries", above n 959, 400.

963 These countries have been described as being at least one or more rungs below developed countries in the economic ladder and constituted the non-aligned Third World during the Cold War. "Preferential Treatment of Developing Countries", above n 959, 400.

${ }^{964}$ These countries are the 48 poorest countries of the world and are said to be one or more rungs lower than the other developing countries in the economic ladder. "Preferential Treatment of Developing Countries", above n 959, 400.
} 
self-selection, ${ }^{965}$ the WTO has not ventured into earmarking the exact criteria that a country must fulfil to qualify as a developing country.

Under the UN, the Economic and Social Council reviews the list of Least Developed Countries (LDCs) of the world every three years. ${ }^{966}$ The latest triennial list of 2003 names 50 countries as LDCs meeting the three criteria of low income, human resource weakness and economic vulnerability. ${ }^{967}$ The Office of the High Representative for the Least Developed Countries, Landlocked Developing Countries and Small Island Developing States also maintains individual lists of Landlocked Developing countries (LLDCs) and Small Island Developing countries (SIDS) among other things. ${ }^{968}$ A number of the LLDCs and SIDS also find a position in the list of LDCs but the common denominator for all the groups is the 'developing' factor. These countries could therefore be considered as definite developing countries as identified by the UN.

Another organisation of merit whose data is often relied upon for the purpose of identifying the developed countries from the developing ones is the Organisation for Economic Cooperation and Development (OECD). The OECD divides aid recipient countries into two main groups - 'Developing Countries', which receive Official Development Assistance and 'Countries and Territories in Transition' receiving Official Aid. ${ }^{969}$ The 'Developing Countries' group is further divided into five subgroups of Least Developed Countries, Other LowIncome Counties, Lower Middle-Income Countries, Upper Middle-Income

\footnotetext{
${ }^{965}$ A country simply needs to declare it to be a developing country and such declaration generally goes unchallenged. An exception to this trend was witnessed in the case of China and its accession negotiation with the WTO, where many WTO members, in particular the United States of America, refused to accept China's accession on that basis. "Preferential Treatment of Developing Countries", above n 959, 400.

966 Under the low-income criterion is based on a three-year average estimate of the gross domestic product per capita (under $\$ 900$ for inclusion, above $\$ 1,035$ for graduation); the human resource weakness criterion involves a composite Augmented Physical Quality of Life Index (APQLI) based on indicators of: (a) nutrition; (b) health; (c) education; and (d) adult literacy; and the economic vulnerability criterion involves a composite Economic Vulnerability Index (EVI) based on indicators of: (a) the instability of agricultural production; (b) the instability of exports of goods and services; (c) the economic importance of non-traditional activities (share of manufacturing and modern services in GDP); (d) merchandise export concentration; and (e) the handicap of economic smallness (as measured through the population in logarithm). The Least Developed Countries $<$ http://r0.unctad.org/ldcs/> (last accessed 4 February 2005).

967 Office of the High Representative for the Least Developed Countries, Landlocked Developing Countries and Small Island Developing States $<$ http://www.un.org/special-rep/ohrlls/ohrlls/default.htm $>$ (last accessed 4 February 2005) [OHRLLS].

${ }_{968}$ OHRLLS, above n 967.

969 OECD DAC List of Aid Recipients as at 1 January 2003 available at $<$ http://www.oecd.org/dataoecd/35/9/2488552.pdf $>$ (last accessed 1 December 2005).
} 
Countries and High-Income Countries. ${ }^{970}$ Similarly, 'Countries and Territories in Transition' are also sub grouped into two parts - Central and Eastern European Countries and New Independent States of the Soviet Union, and More Advanced Developing Countries and Territories. ${ }^{971}$

However, for the purpose of the study, all countries that are not designated as High Income (High Income OECD or Other High Income) by the World Bank shall be treated as developing countries. This selection is based upon the general classification of 'developing countries' as employed by the World Bank in the World Development Report 2006. ${ }^{972}$ The World Development Report 2006 lists the countries of the world according to various income groups ${ }^{973}$ according to 2004 GNI per capita calculated on the basis of the World Bank Atlas method.

ITLOS does not follow any general criteria for the purpose of designating and identifying developing countries. But classification of countries into the developing and developed groups can hardly be expected to have any effect on the procedure or outcome of a dispute settlement procedure they may be involved in. ${ }^{974}$ However, as will be seen later in this chapter, ITLOS identifies for the purposes of its Internship Programme, developing countries as designated by the OECD.

Even in the WTO, where developing countries get preferential treatment, such allowances do not affect the ultimate equality of parties at the time of litigation under the WTO dispute settlement system. ${ }^{975}$ Similarly, all countries are treated equally in keeping with the doctrine of equality under the law, when it comes to the settlement of disputes at ITLOS. Although developing countries do receive some preferential benefits when it comes to extra-judicial interactions with ITLOS, such benefits do not have ramifications in the domain of justice.

\footnotetext{
${ }^{970}$ OECD DAC List of Aid Recipients, above n 969.

${ }^{971}$ OECD DAC List of Aid Recipients, above $\mathrm{n} 969$.

972 The World Bank World Development Report 2006: Equity and Development (The World Bank and Oxford University Press, New York, 2005) xiv [World Development Report 2006].

${ }^{973}$ The groups are: Low Income (LIC), \$ 825 or less; Lower Middle Income (LMC), \$ 8263,255; Upper Middle Income (UMC), \$ 3,256-10,065; and High Income, \$ 10,066 or more. See Selected World Development Indicators in World Development Report 2006, above n 272, 291.

${ }^{974}$ See also "International Justice and Developing Countries", above n 960, 377.

975 "International Justice and Developing Countries", above n 960, 377. For a good discussion on the preferential treatment towards developing countries in international economic law, see Edward A Laing "Equal Access/ Non-discrimination and Legitimate Discrimination in International Economic Law" (1996) 14 Wis Intl L J 246.
} 
This is manifestly clear in Judge Marsit's words, where he referred to the Tribunal's determination of "reasonable bonds" in prompt release cases and asserted, "a reasonable sum must be reasonable for all parties concerned, irrespective of whether they are developed or developing countries." $" 976$ Similarly Judge Laing in the merits of the $M / V$ "Saiga" (No 2) Case sympathetically acknowledged the difficulties and scarce resources at the disposal of developing countries, but was explicit in excluding such considerations from the domain of judicial decision-making. ${ }^{977}$

\section{THE INTERNATIONAL TRIBUNAL FOR THE LAW OF THE SEA AND DEVELOPING COUNTRIES}

The establishment of an effective dispute settlement regime under the Convention was regarded as an important pillar of the new world order in ocean space. ${ }^{978}$ However, on the issue of settlement of disputes, most of the early discussions in UNCLOS III were in connection with the provisions relating to the seabed. ${ }^{979}$ This is hardly surprising as one of the most contentious issues during

976 The "Volga" Case, (Russian Federation $v$ Australia) (Prompt Release) [2002] $<$ http://www.itlos.org/> (last accessed 1 December 2005) para 4 Judge Marsit declaring.

977 The "M/V Saiga" Case (No 2) (Saint Vincent and the Grenadines v Guinea) (Merits) [1999] $<$ http://www.itlos.org/> (last accessed 1 December 2005) para 60 Judge Laing dissenting.

${ }^{978}$ Settlement of Disputes under the Law of the Sea, above n 370, 798. There were some strong oppositions to the creation of ITLOS, see Shigeru Oda "Dispute Settlement Prospects in the Law of the Sea" (1995) 44 ICLQ 863, 864 ["Dispute Settlement Prospects in the Law of the Sea"]; Gilbert Guillaume "The Future of International Judicial Institutions" (1995) ICLQ 848, 854; Shigeru Oda "Some Reflections on the Dispute Settlement Clauses in the United Nations Convention on the Law of the Sea" in Jerzy Makarczyk (ed) Essays in International Law in Honour of Judge Manfred Lachs (Martinus Nijhoff Publishers, The Hague, 1984) 645, 649 ["Some Reflections on the Dispute Settlement Clauses in the United Nations Convention on the Law of the Sea"]; Marianne P Gaertner "The Dispute Settlement Provisions of the Convention on the Law of the Sea: Critique and Alternatives to the International Tribunal for the Law of the Sea" (1981-82) 19 San Diego L Rev 577, 586. See also Robin R Churchill "Dispute Settlement in the Law of the Sea - the Context of the International Tribunal for the Law of the Sea and Alternatives to it" in Malcolm Evans (ed) Remedies in International Law: The Institutional Dilemma (Hart Publishing, Oxford, 1998) 85, 107.

${ }^{979}$ Louis B Sohn "Settlement of Disputes Arising Out of the Law of the Sea Convention" (19741975) 12 San Diego L Rev 495, 496 ["Settlement of Disputes Out of the Law of the Sea"]. For a detailed discourse on developing countries and their interest in the legal regime of the seabed, see Ram Prakash Anand Legal Regime of the Sea-bed and the Developing Countries (Thompson Press Limited, Delhi, 1976) 233 - 264; Hamilton S Amerasinghe "The Third World and the Seabed" in Elisabeth Mann Borgese (ed) Pacem in Maribus (Dodd, Mead \& Company, New York, 1972) 237; David Hegwood "DeepSeabed Mining: Alternative Scheme for Protecting Developing Countries from Adverse Impacts” (1982) 12 Ga J Intl \& Comp L 173. 
UNCLOS III was that of exploitation of the mineral resources on the seabed beyond the limits of national jurisdiction. ${ }^{980}$

The developing countries of the world played an active role in the creation of ITLOS as much as they did in the overall negotiations in UNCLOS III itself. ${ }^{981}$ Borgese has commented in this regard: ${ }^{982}$

Developing countries were clearly in the avant-garde of innovation, and the industrialized states in defence of the status quo. It became clear that the new law of the sea that would emerge from UNCLOS III would be a piece of the New International Economic Order (NIEO) which was the aspiration of the new countries.

Borgese also draws attention to the fact that 59 of the first 60 states to ratify the Convention were developing countries. ${ }^{983}$ This demonstrated the great enthusiasm with which the developing countries embraced the Convention that they have strove so hard to achieve.

It is well known that effective dispute settlement procedures are instrumental in avoiding political, military and economic pressures. ${ }^{984}$ The stake that developing countries had in the establishment of ITLOS as well as the formulation of effective dispute settlement provisions in the LOSC can perhaps be best realised in this context. While it was possible for the wealthy and developed countries to apply extra-legal, political and economic pressures to

\footnotetext{
${ }^{980}$ See generally, James K Sebenius Negotiating the Law of the Sea (Harvard University Press, Cambridge (Mass), 1984) 7-23. For other important issues that were debated at UNCLOS III, see John R Stevenson and Bernard H Oxman "The Preparations for the Law of the Sea Conference" (1974) 68 AJIL 1; John R Stevenson and Bernard H Oxman "The Third United Nations Conference on the Law of the Sea: The 1974 Caracas Session" (1975) 69 AJIL 1; John R Stevenson and Bernard H Oxman "The Third United Nations Conference on the Law of the Sea: The 1975 Geneva Session" (1975) 69 AJIL 763; Bernard H Oxman "The Third United Nations Conference on the Law of the Sea: The 1976 New York Sessions" (1977) 71 AJIL 247; Bernard H Oxman "The Third United Nation's Conference on the Law of the Sea: The 1977 New York Session" (1978) 72 AJIL 57; Bernard H Oxman "The Third United Nations Conference on the Law of the Sea: The Seventh Session (1978)" (1979) 73 AJIL 1.

${ }^{981}$ Settlement of Disputes under the Law of the Sea, above n 370, 818. See generally Hasjim Djalal "The Developing Countries and the Law of the Sea Conference" (1980) IX/1 The Indonesian Quarterly 59; Frank X Njenga "Historical Background of the Evolution of the Exclusive Economic Zone and the Contribution of Africa" in Giulio Pontecorvo (ed) The New Order of the Oceans: The Advent of a Managed Environment (Columbia University Press, New York, 1986) 125; Andrés Aguilar Mawdsley "Law of the Sea: The Latin American View" in Giulio Pontecorvo (ed) The New Order of the Oceans: The Advent of a Managed Environment (Columbia University Press, New York, 1986) 156; Hasjim Djalal "A Southeast Asian Perspective" in Giulio Pontecorvo (ed) The New Order of the Oceans: The Advent of a Managed Environment (Columbia University Press, New York, 1986) 199.

982 Ocean Governance and the United Nations, above n 20, 5.

${ }^{983}$ Ocean Governance and the United Nations, above n 20, 5.

${ }^{984}$ See, Settlement of Disputes Out of the Law of the Sea, above n 979, 516.
} 
achieve their goals, developing countries needed to have disputes directed into legal channels where the principle of equality before the law prevailed. ${ }^{985}$ Compulsory dispute settlement can serve as an instrument of diplomacy and could provide a check on the powers vested with countries as well as a means to protect those powers. ${ }^{986}$

Developing countries had played a crucial role in the establishment of ITLOS. During the negotiations of UNCLOS III, developing countries had displayed little confidence in ICJ. ${ }^{987}$ Many developing countries had not accepted the jurisdiction of ICJ and discontent had been felt towards the Court as a result of the South West African cases. ${ }^{988}$ Therefore developing countries gave full support to the idea arose of establishing a new judicial body to settle disputes concerning ocean space as an alternative to ICJ. Though the establishment of the Tribunal $^{989}$ had been criticised by many delegations as being undesirable and a wasteful duplication of ICJ's functions, such criticism arose primarily from the developed world. ${ }^{990}$

The first suggestion for the establishment of a special tribunal for seabed disputes was seen in the working paper submitted by the United States of

\footnotetext{
${ }^{985}$ Settlement of Disputes Out of the Law of the Sea, above $\mathrm{n}$ 979, 516. See also John E Noyes "Compulsory Third-Party Adjudication and the 1982 United Nations Convention on the Law of the Sea" (1989) 4 Conn J Intl L 675, 681; Andreas J Jacovides "Peaceful Settlement of Disputes in Ocean Conflicts: Does UNCLOS III Point the Way?" in Thomas Buergenthal (ed) Contemporary Issues in International Law, Essays in Honor of Louis B Sohn (N P Engel Publisher, Kehl, 1984) 165, 168.

${ }^{986}$ Klein, above n 265, 53.

987 See generally "International Justice and Developing Countries", above n 960, 379-385. For an in-depth study on the Third World and its resistance to International Law, see Balakrisnan Rajagopal International Law From Below: Development, Social Movements and Third World Resistance (Cambridge University Press, Cambridge, 2003); Balakrisnan Rajagopal "From Resistance to Renewal: The Third World, Social Movements, and the Expansion of International Institutions" (2000) 41 (2) Harv Intl L J 529.

${ }^{988}$ Settlement of Disputes under the Law of the Sea, above $n$ 370, 818.

989 See A R Carnegie "The Law of the Sea Tribunal" (1979) 28 ICLQ 669; Shabtai Rosenne "Establishing the International Tribunal for the Law of the Sea" (1995) 89 AJIL 806; Alan E Boyle "The International Tribunal for the Law of the Sea and the Settlement of Disputes" in Joseph J Norton, Mads Andenas and Mary Footer (eds) The Changing World of International Law in the Twenty-First Century: A Tribute to the Late Kenneth R Simmonds (Kluwer Law International, The Hague, 1997) 99; Mark W Janis "The Law of the Sea Tribunal" in Mark W Janis (ed) International Courts for the Twenty - First Century (Martinus Nijhoff Publishers, Dordrecht, 1992) 245; Renate Platzöder "The International Tribunal for the Law of the Sea" in Mochtar Kusuma Atmadja, Thomas A Mensah and Bernard H Oxman (eds) Sustainable Development and Preservation of the Oceans: The Challenges of UNCLOS and Agenda 21 (The Law of the Sea Institute, University of Hawaii, Honolulu, 1997) 303.

${ }^{990}$ A R Carnegie "The Law of the Sea Tribunal" (1979) 28 ICLQ 669, 682. For a brief account of the conflict of goals between developed and developing countries, see John Warren Kindt "The Effect of Claims by Developing Countries On LOS International Marine Pollution Negotiations" (1980) 20 (2) Va J Intl L 313, 313 - 318.
} 
America to the Seabed Committee in $1970 .{ }^{991}$ In 1971, Malta presented a proposal for a Maritime Court to deal with disputes not only relating to the seabed but a wide variety of related issues such as the high seas, continental shelf, fisheries and preservation of the marine environment among others. ${ }^{992}$ Some of the early drafts containing proposals for the creation of a tribunal for the settlement of ocean disputes that were submitted to the Seabed Committee, originated from developing countries. ${ }^{993}$

\section{A Commitments through Declarations and Agreement}

The proposals for Law of the Sea Tribunal had to undergo many developments during the course of proceedings at UNCLOS III. It took a while before the Tribunal was reasonably acceptable to all delegations, and finally emerged from the negotiation tables. ${ }^{994}$ The Preparatory Commission for the International Seabed Authority and the International Tribunal for the Law of the Sea performed its duties in the 12-year interim period between the points that the LOSC opened for signature to the Tribunal's coming into existence. ${ }^{995}$ It was also during this period that developing countries, like their developed counterparts, completed the declarations that states were obligated to make on ratifying or acceding to the LOSC with regard to choosing to use the Tribunal for the settlement of possible disputes. ${ }^{996}$

\footnotetext{
${ }^{991}$ Hugo Caminos "The Establishment of Specialized Courts" in Myron H Nordquist and John Norton Moore (eds) Current Marine Environmental Issues and the International Tribunal for the Law of the Sea (Kluwer Law International, The Hague, 2001) 33, 34 [Establishment of Specialized Courts]; Hugo Caminos "The Creation of Specialised Courts: The Case of the International Tribunal for the Law of the Sea" in Nisuke Endo and others (eds) Liber Amicorum Judge Shigeru Oda (vol 1, Kluwer Law International, The Hague, 2002) 569, 570.

${ }_{992}$ Establishment of Specialized Courts, above $\mathrm{n}$ 991, 35.

${ }^{993}$ For an analysis of some of these earlier drafts including others from developed States, see Louis B Sohn "A Tribunal for the Sea-Bed or the Oceans" (1972) 32 ZaöRV 253.

${ }^{994}$ For a drafting history demonstrating the major developments, see A O Adede The System for Settlement of Disputes under the United Nations Convention on the Law of the Sea: A Drafting History and a Commentary (Martinus Nijhoff Publishers, Dordrecht, 1987).

${ }^{995}$ Gritakumar E Chitty "A Brief History of the Post Conference Development of the Tribunal as an International Judicial Body" in Myron H Nordquist and John Norton Moore (eds) Current Marine Environmental Issues and the International Tribunal for the Law of the Sea (Kluwer Law International, The Hague, 2001) 41, 44.

${ }^{996}$ LOSC, art 287(1).
} 
As at 1 December 2005, 149 countries had become parties to the LOSC by the process of ratification, accession or succession. ${ }^{997}$ Out of these 149 countries, 26 states have chosen ITLOS as a forum for settling one or more categories of disputes arising from the application and interpretation of the Convention, while only 23 had chosen ICJ. ${ }^{998}$ It is noteworthy that 16 out these 26 countries are developing countries. ${ }^{999}$ Only 37 countries have made definitive declarations under Article 287 of the Convention choosing one of the four dispute settlement forums. ${ }^{1000}$ Therefore for the remaining 112 states parties to the Convention, arbitration under Annex VII of the Convention is the default forum for the settlement of disputes. ${ }^{1001}$

As will be seen in chapter 5, all states are generally reluctant to utilise formal modes of dispute settlement. That probably explains the low number of declarations filed under Article 287 choosing a dispute settlement forum for future disputes. Although not many states have chosen ITLOS as the forum for the future settlement of disputes, it can still be hoped that in the years to come, utilisation of ITLOS will increase and it will have an important role to play. This is possible because (i) states parties may make declarations under Article 287 at any time during or after ratifying the LOSC, ${ }^{1002}$ (ii) ITLOS has compulsory jurisdiction over a variety of issues that parties to a dispute can present for adjudication before it, ${ }^{1003}$ (iii) ITLOS also has jurisdiction to decide over a dispute concerning the interpretation or application of an international agreement related to the purposes of the LOSC. ${ }^{1004}$

\footnotetext{
${ }^{997}$ Division for Ocean Affairs and the Law of the Sea $<$ http://www.un.org/Depts/los/index.htm > (last accessed 8 February 2006). [DOALOS]

998 DOALOS, Settlement of disputes mechanism - Recapitulative Tables, $<$ http://www.un.org/Depts/los/settlement_of_disputes/choice_procedure.htm $>$ (last accessed 1 December 2005) [Recapitulative Table].

${ }_{999}$ These 16 countries are: Argentina, Belarus, Cape Verde, Chile, Croatia, Estonia, Hungary, Latvia, Lithuania, Mexico, Oman, Russian Federation, Tunisia, Ukraine, United Republic of Tanzania and Uruguay. See generally, DOALOS, Declarations and Statements $<$ http://www.un.org/Depts/los/convention_agreements/convention_declarations.htm> (last accessed 1 December 2005).

${ }^{1000}$ Recapitulative Table, above n 998.

${ }^{1001}$ LOSC, art 287(3).

${ }^{1002}$ LOSC, art 287(1).

${ }^{1003}$ Such compulsory jurisdiction can be found under art 292 for the prompt release of vessels and crews, paragraph 5 of art 290 for the prescription of provisional measures pending the constitution of an arbitral tribunal and disputes submitted to the Seabed Disputes Chamber of the Tribunal. Philippe Gautier "The International Tribunal for the Law of the Sea: Activities in 2002" (2003) 2 Chinese J Intl L 341, 348.

${ }^{1004}$ LOSC, art 288(2) and art 21 of Annex VI.
} 
The Agreement on the Privileges and Immunities of the International Tribunal for the Law of the Sea (Agreement on Privileges) was adopted on 23 May 1997 at the seventh meeting of the states parties to the LOSC. ${ }^{1005}$ In accordance with its Article 27, the Agreement on Privileges opened for signature by all states at the UN Headquarters for a period of twenty-four months as from 1 July 1997. This agreement came into force on 30 December 2001 and has 21 parties to it. ${ }^{1006}$ Out of these 21 states, 10 are developing countries. ${ }^{1007}$

It must however be remembered that generally, at least all states parties to the LOSC are bound to extend diplomatic privileges and immunities to the members of ITLOS when engaged in its business. ${ }^{1008}$ Nevertheless, such general provision "is far from sufficient to define the legal status of a permanent international judicial institution or to satisfy the requirements necessary to the exercise of its functions." 1009 This agreement is a comprehensive legal instrument and its ratification by a large number of countries is integral to independent fulfilment by the Tribunal of its essential functions. ${ }^{1010}$ The ratification of this agreement is again in a way suggestive of the way in which states view the Tribunal and appreciate the work and functions of the Tribunal. The declarations under Article 287 and ratification of the Agreement on Privileges by developing states demonstrate their positive commitment to ITLOS.

\footnotetext{
${ }^{1005}$ Agreement on the Privileges and Immunities of the International Tribunal for the Law of the Sea (23 May 1997) 2167 UNTS 271. [Agreement on Privileges]

1006 Status of Multilateral Treaties Deposited with the Secretary-General $<$ http://untreaty.un.org/ENGLISH/bible/englishinternetbible/bible.asp $>$ (last accessed 1 December 2005).

1007 These countries are: Belize, Cameroon, Croatia, Czech Republic, India, Lebanon, Liberia, Lithuania, Panama, and Slovakia. See Status of Multilateral Treaties Deposited with the Secretary-General, above n 1006.

${ }^{1008}$ LOSC, art 10 of Annex VI.

${ }^{1009}$ Joseph Akl "The Legal Status, Privileges and Immunities of the International Tribunal for the Law of the Sea" (1998) 2 Max Planck Yrbk UN L Law 341, 341. ["Legal Status, Privileges and Immunities of ITLOS"].

1010 "Legal Status, Privileges and Immunities of ITLOS", above n 1009, 362.
} 


\section{B Litigation}

The Tribunal is a relatively new body in the arena of International Courts and Tribunals. The LOSC entered into force on 16 November 1994 and Tribunal could hold its first session in 1 October 1996. ${ }^{1011}$ The nine years of its existence is possibly too short a time in the life of an international adjudicatory body to draw definite conclusions about the willingness of states to avail of its services. However, the pattern emerging with regard to cases brought before the Tribunal by developing countries is worth mentioning.

To date, ITLOS has dealt with 13 cases that appeared in its docket. Although the Tribunal also has jurisdiction to deal with cases referred to it under any agreement related to the purposes of the Convention, all of these cases were based on the provisions of the LOSC. ${ }^{1012}$ Seven out of these 13 cases have been about the prompt release of vessels, ${ }^{1013}$ four sought provisional measures, ${ }^{1014}$ one was withdrawn as the parties had reached an agreement ${ }^{1015}$ and another was suspended for the same reason. ${ }^{1016}$ The Tribunal has decided on the merits of one case to date. ${ }^{1017}$

Of these 13 cases, 10 cases saw at least one developing country being involved either as an applicant or a respondent. ${ }^{1018}$ Four cases were brought by a

\footnotetext{
${ }^{1011}$ David H Anderson "The Effective Administration of International Justice: Early Practice of the International Tribunal for the Law of the Sea" in Jochen Abr Frowein and others (eds) Verhandeln Für Den Frieden = Negotiating For Peace: Liber Amicorum Tono Eitel (Springer, Berlin, 2003) 529, 531.

${ }_{1012}$ Ted L McDorman and others International Ocean Law: Materials and Commentaries (Carolina Academic Press, (Durham) North Carolina, 2005) 409. The cases are: The $M / V$ "Saiga" Case, The M/V "Saiga" (No. 2) Case, Southern Bluefin Tuna Cases, The "Camouco" Case, The "Monte Confurco" Case, Case concerning the Conservation and Sustainable Exploitation of Swordfish Stocks in the South-Eastern Pacific Ocean, The "Grand Prince" Case, The "Chaisiri Reefer 2" Case, The MOX Plant Case, The "Volga" Case, Case concerning Land Reclamation by Singapore in and around the Straits of Johor, and The "Juno Trader" Case.

${ }^{1013}$ The M/V "Saiga", "Camouco", "Monte Confurco", "Grand Prince", "Chaisiri Reefer 2", "Volga" and "Juno Trader" Cases.

${ }^{1014}$ The Southern Bluefin Tuna Cases, MOX Plant Case and Case concerning Land Reclamation by Singapore in and around the Straits of Johor.

${ }^{1015}$ The "Chaisiri Reefer 2" Case.

1016 The Case concerning the Conservation and Sustainable Exploitation of Swordfish Stocks in the South-Eastern Pacific Ocean.

1017 The M/V "Saiga" (No. 2) Case.

${ }^{1018}$ The M/V "Saiga", M/V "Saiga" (No. 2), "Camouco", "Monte Confurco", Case concerning the Conservation and Sustainable Exploitation of Swordfish Stocks in the South-Eastern Pacific Ocean, "Grand Prince", "Chaisiri Reefer 2", "Volga", Case concerning Land Reclamation by Singapore in and around the Straits of Johor and "Juno Trader" Cases.
} 
developing country against another developing country ${ }^{1019}$ and six cases had been instituted by a developing country against a developed country. ${ }^{1020}$ The remaining three cases were disputed between developed countries. ${ }^{1021}$ Similarly, out of the 13 cases, there were three cases that had been instituted by a developed country at ITLOS. ${ }^{1022}$

Going by percentage, 76.9 per cent of cases brought before ITLOS have involved a developing country, 30.8 per cent of the cases were between developing countries and 46.1 per cent of the cases were filed by a developing country against a developed country. ${ }^{1023}$ Again, it can be seen that of all cases that been brought before the Tribunal, 77 per cent have come from developing countries and 23 per cent have come from developed countries. These high figures demonstrating the involvement of developing countries in international adjudication is reflective of their willingness to use ITLOS as the forum for the settlement of relevant disputes. In a commentary about the $M / V$ "Saiga” Cases, one scholar has noted that such "recourse to the Tribunal is consonant with recent practise in other fora, where developing countries are increasingly resorting to international adjudication in order to resolve their disputes."1024 However, it has been argued elsewhere that developing countries might, given the opportunity, prefer to use ITLOS as against the ICJ. ${ }^{1025}$

In this exercise it is also probably meaningful to contrast the above figure of cases involving developing countries at ITLOS with the ratifications of the LOSC. ${ }^{1026}$ As of 1 December 2005, the LOSC has 149 parties to it. ${ }^{1027}$ Of these,

\footnotetext{
1019 The M/V “Saiga”, M/V “Saiga” (No. 2), “Chaisiri Reefer 2" Case and "Juno Trader” Cases.

1020 The "Camouco", "Monte Confurco", Case concerning the Conservation and Sustainable Exploitation of Swordfish Stocks in the South-Eastern Pacific Ocean, "Grand Prince”, "Volga" and Case concerning Land Reclamation by Singapore in and around the Straits of Johor and cases.

${ }^{1021}$ The Southern Bluefin Tuna Cases and MOX Plant Case.

${ }^{1022}$ The Southern Bluefin Tuna Cases and MOX Plant Case.

${ }^{1023}$ It has been argued that perhaps it is not entirely accurate to categorise prompt release cases like The M/V "Saiga”, “Camouco”, "Monte Confurco", "Grand Prince”, "Chaisiri Reefer 2", "Volga" and "Juno Trader" as cases brought by developing countries. This is based on the premise that an application for prompt release of vessels and crews under Art 292 of the LOSC maybe brought by or on behalf of the flag Sate of the vessel. "International Justice and Developing Countries", above n 960, 399.

1024 "ITLOS and the Saga of the Saiga", above n 740, 356.

1025 "International Justice and Developing Countries", above n 960, 399.

1026 “International Justice and Developing Countries", above n 960, 399.

${ }^{1027}$ DOALOS $<$ http://www.un.org/Depts/los/reference_files/chronological_lists_of_ratifications.ht m\#The United Nations Convention on the Law of the Sea> (last accessed 1 December 2005).
} 
117 parties belong to the developing world and 32 to the developed world. ${ }^{1028}$ Again in terms of percentage, 78.5 per cent of the parties to the LOSC are from developing countries and 21.5 per cent from developed countries. It is interesting to note that the percentage figure of representation of developing countries within the legal framework of the LOSC coincides with that of the percentage of cases brought by developing countries before ITLOS. Thus it can be concluded that developing countries as a group are not overrepresented at the Tribunal. ${ }^{1029}$

\section{Financial Resources}

As far as financial resources from developing countries are concerned, ITLOS receives an annual contribution from the states parties to the LOSC. Similarly, there are certain avenues of financial assistance that especially developing countries can avail of in approaching ITLOS for the settlement of disputes.

\section{Contributions of states parties to the budget of the tribunal}

According to Article 19 of the Statute of the International Tribunal for the Law of the Sea, the expenses of the Tribunal are to be borne by the states parties to the LOSC. ${ }^{1030}$ Decisions regarding the scale of assessments for contributions by individual states parties to the budget of the Tribunal are taken in the annual meeting of states parties. According to the thirteenth meeting of states parties: ${ }^{1031}$

[C]ontributions to be made by the States Parties to the budget of the Tribunal for the period 2005-2006 shall be based upon the scale of assessments for the regular budget of the United Nations for the financial year 2004 adjusted to take account of participation in the Convention.

\footnotetext{
1028 Of the 34 parties from developed countries, 22 are OECD member and the others are Bahamas, Bahrain, Brunei Darussalam, Cyprus, Kuwait, Malta, Monaco, Qatar, Singapore and Slovenia, designated as Other High Income countries by the World Bank.

1029 "International Justice and Developing Countries", above n 960, 399. A similar study can also be found here with reference to the ICJ.

${ }^{1030}$ LOSC, art 19(1) of Annex VI.

1031 Thirteenth meeting of States Parties, New York, 9-13 June 2003 UN Doc SPLOS/97 $<$ http://www.un.org/Depts/los/meeting_states_parties/SPLOS_documents.htm $>$ (last accessed 9 February 2005) para 2.
} 
Also in calculating the annual contribution to be made by each state party, a floor rate and a ceiling rate are taken into consideration. For the budget of the Tribunal for 2005-2006, a floor rate of 0.01 per cent and a ceiling rate of 22 per cent had been fixed. ${ }^{1032}$ The Tribunal has its own system of fixing the floor and ceiling rates that is based upon the figures as agreed in the meeting of states parties. ${ }^{1033}$ In accordance with this, in the Tribunal's annual budget for 2005, the floor rate has been kept at 0.0100 per cent and the ceiling at 22 per cent. ${ }^{1034}$ Under this determined scale for contributions, a country required to contribute according to the floor rate is assessed for a sum of EUR $768 .^{1035}$ There are 63 countries that have been assessed to make their annual contribution to the Tribunal's budget for 2005 by the floor rate. ${ }^{1036}$ Out of these 63 countries, 61 are developing countries and for them, the requirement to pay a modest sum of EUR 768 as an annual contribution must certainly seem to be welcome. ${ }^{1037}$ Like the adage "little drops of water make great oceans", contributions made by developing countries along with their developed counterparts provide the finances for the maintenance and upkeep of the Tribunal.

\section{Financial assistance to developing countries for the settlement of disputes}

It is understood that only in order and the rule of law can there be real protection for the small and the weak. ${ }^{1038}$ But it is equally true that third party dispute settlement can be time consuming and expensive, and only large and

\footnotetext{
${ }^{1032}$ Fourteenth meeting of States Parties, New York, 14-18 June 2004 UN Doc SPLOS/117 $<$ http://www.un.org/Depts/los/meeting_states_parties/SPLOS_documents.htm $>$ (last accessed 9 February 2005).

${ }^{1033}$ Since there is a basic difference in the number of States parties to the United Nations and to that of the LOSC, the rate of calculation of individual State contribution varies. The United Nations has 191 States as parties to it whereas ITLOS has 148 States parties contributing to its budget.

${ }_{1034}$ Office of Budget and Finance, International Tribunal for the Law of the Sea.

${ }^{1035}$ Office of Budget and Finance, above n 1034.

${ }^{1036}$ Office of Budget and Finance, above n 1034.

1037 The two developed and high-income countries paying at the floor rate are Antigua and Barbuda, and Monaco.

1038 Tuiloma Neroni Slade "The Making of International Law: The Role of Small Island States" (2003) 17 Temp Intl \& Comp L J 531, 531. For perspectives on the engagement of small island states in ocean issues, see the individual articles in Seas, Oceans and Small Islands (2004) 15 (1) Our Planet, available

$<$ http://www.ourplanet.com/imgversn/151/images/Our Planet 15.1 english.pdf $>$ (last accessed 11 November 2005).
} 
wealthy states can easily afford it. ${ }^{1039}$ One of the most important factors that developing states need to grapple with on the question of question of peaceful settlement of disputes by third party adjudication, is that of costs. It was felt that that burden of costs should be allowed to become a prohibitive factor for states neither in deciding to use the Tribunal for the settlement of disputes under the LOSC nor in deciding upon the response to an application made to ITLOS by others. ${ }^{1040}$

There are two Trust Funds that have been established that developing countries can seek financial assistance from in the settlement of their disputes relating to the law of the sea. The first is called the International Tribunal for the Law of the Sea Trust Fund (ITLOS Trust Fund). The purpose of this Fund is to provide financial assistance to states parties to the LOSC for the expenses incurred in submitting a dispute to ITLOS. ${ }^{1041}$ The second is the Assistance Fund under Part VII of the Fish Stocks Agreement (Fish Stocks Assistance Fund). The purpose of this Fund is to provide financial assistance to developing states parties to the Fish Stocks Agreement to assist in the implementation of the Fish Stocks Agreement. ${ }^{1042}$

The decision to recommend the establishment of the ITLOS Trust Fund to the General Assembly of the UN was taken in the tenth meeting of states parties to the LOSC. ${ }^{1043}$ It started with an initial proposal made by the United Kingdom delegation to establish a trust fund to financially assist states in proceedings before ITLOS, along the lines of the Trust Fund established for the ICJ. ${ }^{1044}$ The Secretary General in accordance with the General Assembly resolution 55/7 and the Agreement on Cooperation and Relationship between the

\footnotetext{
1039 Andrew A Jacovides "International Tribunals: Do They Really Work for Small States?" (2001) 34 N Y U J Intl L \& Pol 253, 260.

${ }^{1040}$ Terms of reference, International Tribunal for the Law of the Sea Trust Fund, UN Doc A/RES/55/7 <http://www.un.org $>$ (last accessed 10 February 2005) para 2. [Terms of reference ITLOS Trust Fund].

${ }^{1041}$ Terms of reference ITLOS Trust Fund, above n 1040, para 5.

1042 Terms of reference of the Assistance Fund, available at $<$ http://www.un.org/Depts/los/convention_agreements/fishstocktrustfund/fishstocktrustfund.htm> (last accessed 10 February 2005) para 6 [Terms of Reference Fish Stocks Assistance Fund].

1043 Tenth Meeting of States Parties, New York, 22-26 May 2000, UN Doc SPLOS/57 $<$ http://www.un.org/Depts/los/meeting_states_parties/SPLOS_documents.htm $>$ (last accessed 10 February 2005).

${ }^{1044}$ Vaughan Lowe "The International Tribunal for the Law of the Sea: Survey for 2000" (2001) 16 (4) IJMCL 549. For a comparison between the ICJ Trust Fund and the ITLOS Trust Fund, see David Anderson "Trust Funds in International Litigation" in Nisuke Endo and others (eds) Liber Amicorum Judge Shigeru Oda (vol 2, Kluwer Law International, The Hague, 2002) 793.
} 
United Nations and the International Tribunal for the Law of the Sea established the ITLOS Trust Fund in 2000. ${ }^{1045}$ This is a voluntary Trust Fund and accepts contributions from states, intergovernmental organisations, as well as natural and juridical persons. ${ }^{1046}$ The Division for Ocean Affairs and the Law of the Sea (DOALOS) of the UN Office of Legal Affairs is the implementing office for the ITLOS Trust Fund and provides the services for the operation of the Fund. ${ }^{1047}$ This Fund exists to provide not only financial assistance but also other relevant assistance with regard to the settlement of disputes at ITLOS. The implementing office maintains a list of offers of professional assistance made on a reduced fee basis by suitably qualified persons or bodies. ${ }^{1048}$ Both forms of assistance, financial as well as otherwise, may be extended in respect of the same case or any of its phases. ${ }^{1049}$

It is however to be noted that any state party to the LOSC can seek assistance from this Fund and therefore this Fund is not exclusively reserved for the use by developing countries. ${ }^{1050}$ It may however be argued that since it is the developing countries that have limited financial recourses in comparison to developed countries, the assistance from the Fund would generally be sought by and granted to them. The corpus of the Fund as at 31 December 2004 was US \$ 69,153.90 with contributions from the Government of the United Kingdom and Northern Ireland, and the Government of Finland. ${ }^{1051}$ The financial costs involved in international dispute settlement can be substantial, and in this light, the corpus of the Fund seems rather insufficient to be able to provide any real assistance to a country in need of it.

The developed countries do not seem to be inclined to make contributions to this Trust Fund. Except for the United Kingdom and Finland, no other nation has made a contribution towards this cause. Further lack of support for the Fund is clear from the fact that no contributions were received into the

\footnotetext{
1045 See ITLOS Trust Fund <http://www.un.org/Depts/los/ITLOS/itlos_trust_fund.htm> (last accessed 10 February 2005).

1046 Terms of reference ITLOS Trust Fund, above n 1040, para 6.

${ }^{1047}$ Terms of reference ITLOS Trust Fund, above n 1040, para 12.

${ }^{1048}$ Terms of reference ITLOS Trust Fund, above n 1040, para 13.

${ }^{1049}$ Terms of reference ITLOS Trust Fund, above n 1040, para 13.

${ }^{1050}$ Terms of reference ITLOS Trust Fund, above n 1040, para 7.

1051 Report of the Secretary General on Oceans and Law of the Sea, $60^{\text {th }}$ Session UN Doc A/60/63, para 55; Report of the Secretary General on Oceans and Law of the Sea, $59^{\text {th }}$ Session UN Doc A/59/62/Add.1, para 154. See also Annual Report of the International Tribunal for the Law of the Sea 2003, UN Doc SPLOS/109, para 84 [Annual Report of ITLOS 2003].
} 
Fund in 2004. ${ }^{1052}$ No information is available about any contribution that has been made to the Fund so far in 2005. The need for Trust Fund has already been established with a request made to the DOALOS in 2004 for assistance from the Fund. ${ }^{1053}$ Guinea-Bissau made the first ever application to the Fund for financial assistance to defray the costs incurred by it in the "Juno Trader" Case. ${ }^{1054}$ US \$ 20,000 was disbursed from the Fund following the Secretary General's approval to the recommendations of a panel of experts, formed under terms of reference for the Fund, composed of members from China, Russia and the United Kingdom. ${ }^{1055}$

The General Assembly at its $58^{\text {th }}$ Session, decided to establish an Assistance Fund in accordance with Part VII of the Fish Stocks Agreement. ${ }^{1056}$ Assistance under the Fund can be provided exclusively to developing countries that are parties to the Agreement for a wide range of purposes. ${ }^{1057}$ Under Paragraph $14(\mathrm{~g})$ of the terms of reference for the Fund, assistance could be given to qualifying countries in meeting the costs involved in the settlement of disputes concerning the interpretation or application a sub regional, regional or global fishery agreement relating to straddling fish stocks or highly migratory fish stocks. It is significant to point out that such financial assistance under the Fish Stocks Assistance Fund can complement any assistance that a country may receive under the ITLOS Trust Fund, provided it meets the necessary qualifying criteria for both. ${ }^{1058}$ Therefore in case of a dispute before ITLOS that involves straddling or highly migratory fish stocks governed by a sub-regional, regional or global fishery agreement, a developing country may seek assistance from the Fish Stocks Assistance Fund as well as the ITLOS Trust Fund. Such provisions could empower developing states greatly in settling their disputes peacefully and also provide opportunities to dispute settlement mechanisms to contribute to oceans governance.

\footnotetext{
1052 Report of the Secretary General on Oceans and Law of the Sea, $60^{\text {th }}$ Session, above $n 1051$, para 55.

${ }_{1053}$ Annual Report of ITLOS, above n 1051, para 83.

${ }^{1054}$ Report of the Secretary General on Oceans and Law of the Sea, $60^{\text {th }}$ Session, above $n 1051$, para 55.

${ }^{1055}$ Report of the Secretary General on Oceans and Law of the Sea, $60^{\text {th }}$ Session, above $n 1051$, para 55.

${ }^{1056}$ By Resolution A/58/14. See Para 1 of the terms of reference of the Fish Stocks Fund, above $\mathrm{n}$ 1042.

${ }^{1057}$ Terms of Reference Fish Stocks Assistance Fund, above n 1042, para 14.

1058 Terms of Reference Fish Stocks Assistance Fund, above n 1042, para 14(g).
} 
The FAO acts as the implementing office for the Fund in collaboration with the United Nations. ${ }^{1059}$ The Fish Stocks Assistance Fund can receive voluntary financial contributions from states, intergovernmental organisations, international financial institutions, national institutions, NGOs as well as natural and juridical persons. ${ }^{1060}$ The corpus of the Fund stands at US \$200,000 comprising of contributions from the United States of America. ${ }^{1061}$ It has been said that the establishment of the Fund would aid developing states parties in implementing the Agreement as well as encourage more states to become parties to the Agreement. ${ }^{1062}$

In conclusion, it would appropriate to recommend that developed countries could also play an important role in this regard by showing more tangible support, such as by contributing better to the trust funds. In part IV of chapter 2, some of the ways in which dispute settlement can play a role in oceans governance had been enumerated. It is concluded here that by helping developing countries in participating in the dispute settlement process, it is ensured that in the event a dispute, ITLOS has an opportunity to play a role in oceans governance.

\section{Human Resources}

Developing countries interact with the Tribunal for the settlement of disputes not just on financial levels as described in the previous paragraphs but also with respect of human resources. There are two important ways in which developing countries contribute to the Tribunal in this regard and in return, benefit greatly too.

\footnotetext{
${ }^{1059}$ Terms of Reference Fish Stocks Assistance Fund, above n 1042, para 7.

${ }^{1060}$ Terms of Reference Fish Stocks Assistance Fund, above n 1042, para 11.

${ }^{1061}$ Third Informal Consultations of the States Parties to the Agreement for the Implementation of the Provisions of the United Nations Convention on the Law of the Sea of 10 December 1982 relating to the Conservation and Management of Straddling Fish Stocks and Highly Migratory $\begin{array}{llllll}\text { Fish } & \text { Stocks, } & \text { New } & \text { York } & 8-9 & \text { July }\end{array}$ $<$ http://www.un.org/Depts/los/convention_agreements/convention_overview_fish_stocks.htm> (last accessed 10 February 2005) para 39 [Third Informal Consultations of States Parties to the Agreement].

${ }^{1062}$ Third Informal Consultations of States Parties to the Agreement, above n 1061, para 40.
} 


\section{$1 \quad$ Judges}

The tribunal is composed of 21 independent Judges representing the principal legal systems of the world and ensuring the equitable geographical distribution from around the world. ${ }^{1063}$ Candidates fit for nomination for the membership ITLOS need to be "enjoying the highest reputation for fairness and integrity and of recognized competence in the field of the law of the sea."1064

Each state party is allowed to nominate up to two qualified persons for membership in the Tribunal and final candidates are elected from this list of nominees. ${ }^{1065}$ For the first election, 33 candidates had been nominated for the 21 places available. ${ }^{1066}$ Of these 33 nominations, 21 came from developing countries. ${ }^{1067}$ Finally, 15 of the 21 nominees from developing countries were elected as Judges of the Tribunal. ${ }^{1068}$ This numerical representation of developing countries in the membership of the Tribunal is preserved even today. ${ }^{1069}$ The present composition of the Tribunal is reflected in TABLE III. $^{1070}$

\footnotetext{
${ }^{1063}$ LOSC, art 2(1) of Annex VI .

${ }^{1064}$ LOSC, art 2(1) of Annex VI.

${ }^{1065}$ LOSC, art 4 of Annex VI.

1066 "Dispute Settlement and the Law of the Sea: The UN Convention Regime", above n 445, 35.

1067 See "Dispute Settlement and the Law of the Sea: The UN Convention Regime", above n 445, 36.

1068 See "Dispute Settlement and the Law of the Sea: The UN Convention Regime", above n 445, 37.

${ }^{1069}$ See Table - III Members of ITLOS and the Country of Origin, 182.

1070 Modified from - General Information - Judges < http://www.itlos.org > (last accessed 1 December 2005).
} 
TABLE - III MEMBERS OF ITLOS AND THEIR COUNTRY OF ORIGIN

\begin{tabular}{|c|c|c|c|c|}
\hline $\begin{array}{l}\text { Sl. } \\
\text { No. }\end{array}$ & Position & $\begin{array}{l}\text { Name (in order of } \\
\text { precedence as depicted } \\
\text { in ITLOS website) }\end{array}$ & Country & $\begin{array}{c}\text { Country } \\
\text { Development } \\
\text { Status } \\
\end{array}$ \\
\hline 1. & President & Rüdiger Wolfrum & Germany & Developed \\
\hline 2. & $\begin{array}{c}\text { Vice- } \\
\text { President }\end{array}$ & Joseph Akl & Lebanon & Developing \\
\hline 3. & Judge & Hugo Caminos & Argentina & Developing \\
\hline 4. & Judge & Vicente Marotta Rangel & Brazil & Developing \\
\hline 5. & Judge & Alexander Yankov & Bulgaria & Developing \\
\hline 6. & Judge & $\begin{array}{l}\text { Anatoly Lazarevich } \\
\text { Kolodkin }\end{array}$ & $\begin{array}{c}\text { Russian } \\
\text { Federation }\end{array}$ & Developing \\
\hline 7. & Judge & Choon-Ho Park & $\begin{array}{l}\text { Republic of } \\
\text { Korea }\end{array}$ & Developed \\
\hline 8. & Judge & Paul Bamela Engo & Cameroon & Developing \\
\hline 9. & Judge & L. Dolliver M. Nelson & Grenada & Developing \\
\hline 10. & Judge & P. Chandrasekhara Rao & India & Developing \\
\hline 11. & Judge & Tullio Treves & Italy & Developed \\
\hline 12. & Judge & Tafsir Malick Ndiaye & Senegal & Developing \\
\hline 13. & Judge & José Luis Jesus & Cape Verde & Developing \\
\hline 14. & Judge & Guangjian $\mathrm{Xu}$ & China & Developing \\
\hline 15. & Judge & Jean-Pierre Cot & France & Developed \\
\hline 16. & Judge & Anthony Amos Lucky & $\begin{array}{c}\text { Trinidad } \\
\text { and Tobago }\end{array}$ & Developing \\
\hline 17. & Judge & Stanislaw Pawlak & Poland & Developing \\
\hline 18. & Judge & Shunji Yanai & Japan & Developed \\
\hline 19. & Judge & Helmut Türk & Austria & Developed \\
\hline 20. & Judge & James Kateka & Tanzania & Developing \\
\hline 21. & Judge & Albert Hoffmann & $\begin{array}{l}\text { South } \\
\text { Africa }\end{array}$ & Developing \\
\hline
\end{tabular}


Having such a global representation on the bench of the Tribunal augurs well for developing countries as they are assured of having judges who have sympathetic views toward their problems and attitudes about international law. ${ }^{1071}$

It is acknowledged that: ${ }^{1072}$

The true judge has no nationality. He is the priest of justice; he carries the scales; he defends the truth against falsehood; he looks neither to the right nor to the left; he takes no thought of private interests nor of political ambitions. He is not a Frenchman, a Greek or a Bolivian; he is first and last a judge.

However, it must also be remembered that only an international court or tribunal that is representative of the various legal systems and interests in the world can crystallise general principles that are common to national legal systems of the world. ${ }^{1073}$ Thus, going simply by the fact of worldwide representation on the bench, the Tribunal must appear as an attractive forum for the settlement of relevant disputes.

\section{Interns}

As has been seen in Chapter 2, dispute settlement has an important role to play in oceans governance. Quite clearly, most developing countries of the world today lack the diplomatic and legal expertise to effectively handle any ocean dispute that they may get embroiled in. ${ }^{1074}$ It is argued here that that internship programme at ITLOS and the funding arrangements available for nationals of developing countries goes a long way in legal capacity building in developing countries, and in the long run increasing their involvement in the dispute settlement process.

Modelled along the lines of the UN internship programme, the internship programme of ITLOS was established in 1997. ${ }^{1075}$ The object of the internship programme is to give participants an opportunity to gain an insight into the work and

${ }^{1071}$ Studies in International Adjudication, above n 536, 81.

1072 Documents Concerning the Action Taken by the Council of the League of Nations under Article 14 of the Covenant and the Adoption by the Assembly of the Statute of the Permanent Court (Geneva, 1921) 230, cited in Ram Prakash Anand International Courts and Contemporary Conflicts (Asia Publishing House, London, 1974) 99.

${ }^{1073}$ Sorenson "The International Court of Justice: Its role in Contemporary International Relations" (1960) 14 International Organization, 263 cited in Studies in International Adjudication, above n 536, 111.

${ }^{1074}$ Hinds, above n 340, 355. See also Emmanuel G Bello "International Equity and the Law of the Sea: New Perspectives for Developing Countries” (1980) 13 Verfassung und Recht in Übersee 201, 201.

${ }^{1075}$ Annual Report of ITLOS 2003, above n 1051, para 90. 
functions of the Tribunal. ${ }^{1076}$ The Tribunal and its members also benefit from the services of such interns with knowledge and skills in the area of competence of the Tribunal. ${ }^{1077}$ To date, 138 interns from 54 countries have served at the Tribunal. ${ }^{1078}$

During its sixteenth session, ITLOS took note of an offer made by Korea International Cooperation Agency (KOICA) with regard to the possible funding of participation in its internship programme. ${ }^{1079}$ In March 2004, the KOICA Grant was established by the Registrar of ITLOS to assist interns from developing countries to participate in the internship programme of the Tribunal. ${ }^{1080}$ With a generous contribution of UD \$ 150,000 from KOICA, the Tribunal took up the charge to administer the fund and to support financially the participation of interns from developing countries in its internship programme. ${ }^{1081}$ As at 1 December 2005, 31 interns hailing from developing countries had received or had been deemed eligible for receiving, financial assistance from the KOICA Grant for the tenure of their internship at ITLOS. ${ }^{1082}$ The selection processes of interns by the Tribunal gives due regard to geographical diversity and gender balance. $^{1083}$

It is submitted that the establishment of the KOICA Grant has been a laudable development at ITLOS. Developing countries often lack the sort of skilled human resources that developed countries can boast of, and this extends even to legal expertise. ${ }^{1084}$ Being able to offer a financially funded internship programme to nationals of developing countries, ITLOS plays an important role in increasing the available skill sets of developing countries especially in the field of the law of the sea. Education, training and capacity building are the stepping-stones to the implementation of the laws,

1076 General Information - Employment/ Interns/ Public Announcements <http://www.itlos.org $>$ (last accessed 10 February 2005).

${ }^{1077}$ General Information - Employment/ Interns/ Public Announcements, above n 1076.

${ }^{1078}$ Press Office, International Tribunal for the Law of the Sea.

1079 Annual Report of ITLOS 2003, above n , 1051 para 92.

${ }^{1080}$ Report of the fourteenth Meeting of States Parties, New York, 14-18 June 2004, UN Doc SPLOS/119, para 29.

${ }_{1081}$ Report of the fourteenth Meeting of States Parties, above n 1080, para 29.

1082 Press Office, International Tribunal for the Law of the Sea.

${ }^{1083}$ General Information - Internship programme - Information Sheet $<$ http://www.itlos.org $>$ (last accessed 10 February 2005).

${ }^{1084}$ See Jean-Pierre Cot "Appearing 'For' or 'On Behalf of' a State: The Role of Private Counsel Before International Tribunals" in Nisuke Endo and others (eds) Liber Amicorum Judge Shigeru Oda (vol 2, Kluwer Law International, The Hague, 2002) 835, 837 - 838; Choon-Ho Park "Judicial Settlement of International Maritime Disputes - An Overview of the Current System" (1999) 28 Stetson L Rev 1035, 1044. 
rules and regulations that form an integral part of the oceans governance process. Arguably, the very essence of oceans governance lies in identifying and filling this capacity gap. ${ }^{1085}$ The Tribunal, playing a role in the capacity building process, though in limited measure, advances the course of good oceans governance. In aiding in the understanding and respect for the law of the sea, and generally increasing the participation of developing countries in the dispute settlement process, ITLOS is enlarging the potential opportunities for dispute settlement to influence oceans governance. In this way, ITLOS indirectly advances the cause of good oceans governance not just for the developing countries, but also for the whole world.

\section{CONCLUSIONS}

ITLOS, and the developing countries of the world taken as group have witnessed positive growth in their relationship and interaction with each other. As has been seen in this chapter, they have in the past and still continue to interact at many levels. However, it is also felt that there exists sufficient room for the further development of relations between ITLOS and developing countries.

From the standpoint of developing countries this could possibly be best achieved by their increased willingness to settle their relevant disputes at the Tribunal. Similarly, the Tribunal could reach out better to its developing world clients by making its presence felt and work understood more proactively. ${ }^{1086}$ ITLOS can do more in this regard by extending training and other related assistance to appropriate entities in developing countries. This will further encourage the participation of developing countries in the dispute settlement process. Developed countries could play an important role in the process by committing more resources for the upkeep of trust funds and even manpower deployment for training purposes. It is hoped that the future shall witness developing

\footnotetext{
${ }^{1085}$ It is to address such capacity gaps that research and learning institutes such as the International Ocean Institute are dedicated. International Ocean Institute Training on Ocean Affairs, Business Strategy 2005 $2008<$ http://www.ioinst.org/> (last accessed 20 October 2005).

${ }^{1086}$ In 2006, the Tribunal aims to hold conferences in different parts of the world, benefiting from the participation of its Judges hailing from the relevant regions. See Judge Rüdiger Wolfrum, President of ITLOS (Statement on Agenda Item 75 (a) at the Plenary of the Sixtieth Session of the United Nations

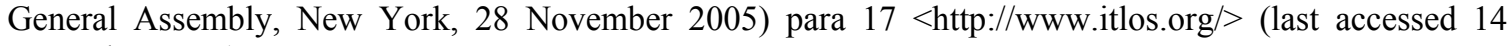
December 2005).
} 
countries reposing greater trust on the Tribunal, and the bonds grow stronger between the two.

With an increasing involvement of developing countries with ITLOS, it is hoped that they would come to realise the benefits of dispute settlement better and be more willing to use the dispute settlement mechanisms of the Convention. This in turn would give greater opportunities to the dispute settlement mechanisms to play a role in oceans governance as argued in chapter 2. 


\section{CHAPTER 5}

\section{THE FUTURE OF DISPUTE SETTLEMENT IN OCEANS GOVERNANCE}

The aim of this chapter is to draw together the main findings from chapter 2,3 and 4 , and to use them to make predictions about the future role of dispute settlement in oceans governance. Part I of this chapter shows that, as against the considerable potential of dispute settlement in oceans governance, to date little has actually been achieved in this regard. This is primarily attributable to the general reluctance of states to utilise formal dispute settlement mechanisms, and this is discussed under part III. Though to a lesser extent, the limitations and optional exceptions to the operation of the compulsory dispute settlement procedures under the Convention are also responsible for the limited role that dispute settlement has played in oceans governance, and this is considered in part IV. A critical assessment of ITLOS is provided in part II.

However, part $\mathrm{V}$ paints a brighter future for dispute settlement in oceans governance, and puts forward a few recommendations that could help realise the true potential of dispute settlement in oceans governance. Part VI generally highlights the limitations of dispute settlement, which explains why its potential role in oceans governance also has its limitations. The chapter concludes with a realistic hope that the actual role of dispute settlement in oceans governance will improve in the future.

\section{POTENTIAL VERSUS ACTUAL ROLE}

Chapter 2 has revealed that there is enormous potential for the LOSC dispute settlement machinery to contribute to oceans governance. Such potential has been seen extending to a number of areas, which can be non-exhaustively listed as follows: (i) enforcement and implementation of the Convention, (ii) maintenance of the integrity of the principles governing the Convention, (iii) unification of the substantive legal provisions of the Convention, (iv) provision of protection from abuse, (v) regulation and

allocation of resources, (vi) maritime boundary delimitation, (vii) strengthening of regimes and institutions, (viii) interpretation of the law and development of rules, (ix) 
facilitation of cooperation, (x) reduction of tension and maintenance of peace, (xi) ensuring compliance with laws and norms, and (xii) management of multiple ocean use conflicts.

Chapter 3 brought out the actual role that ITLOS, and other dispute settlement bodies under the Convention have played in oceans governance. It was seen that certain elements of the jurisprudence so far did not have a constructive influence on oceans governance, particularly those relating to prompt release. The discounting of bonds has led to uncertainties among coastal states as to the nature of a "reasonable" bond, and ITLOS has been unable to give clear guidance in this regard. ITLOS has also been unable to rise to the call of coastal states in bolstering their efforts against IUU fishing. Inconsistencies have been noticed in the Tribunal's prompt release jurisprudence, particularly that relating to the consideration of the proceeds of catch in determining a reasonable bond. However, it must be said that the prompt release cases have led to the (i) interpretation of the law, and (ii) maintenance of peace and security, in keeping with the humanitarian values of prompt release procedures.

Provisional measures cases and the subsequent judicial proceedings were seen to have played a largely beneficial role in oceans governance. Their contribution to oceans governance has been primarily through - (i) facilitation of co-operation between states, (ii) ensuring compliance with laws and norms, (iii) maintenance of the integrity of the principles governing the Convention, and generally (iv) reducing tension and maintaining peace.

In the only dispute on merits adjudicated under the Convention to date, ${ }^{1087}$ ITLOS played a beneficial role in oceans governance. This was by way of (i) interpreting and clarifying the law on customs enforcement in the EEZ, hot pursuit, and the use of force, (ii) providing protection from abuse, and (iii) maintaining the integrity of one of the core principles governing the Convention respecting the delicate balance of interests between coastal states and flag states.

It was concluded that though the overall influence of dispute settlement on oceans governance had been mostly constructive, the real impact of the cases on oceans governance was less significant. This is because most the cases disputed so far have been

${ }^{1087}$ The M/V "Saiga”(No 2) - Merits, above n 746. 
interlocutory in nature and have only sought interim relief, and also perhaps due to the limited time frame within which the dispute settlement machinery has been in operation.

In chapter 4 , it was seen that ITLOS as a dispute settlement body under the Convention was indirectly contributing to good oceans governance, mostly outside the administration of justice, through its engagement with developing countries. But most importantly, it was argued that by encouraging the participation of developing countries in the dispute settlement process, the opportunities for dispute settlement in oceans governance was being greatly enlarged. Here too, the potential for a much greater role was perceived for the future.

Since dispute settlement's impact on oceans governance has been rather limited so far, even the emergence of some detrimental elements from the formative case law has not done much harm. However, even in their limited roles, dispute settlement bodies have given meaning to some of the broad principles of the Convention, ${ }^{1088}$ and fostered world peace and security through international co-operation. As has been evidenced by the Tribunal's jurisprudence in provisional measures cases, international judicial decisions in ocean law have helped disputant states to reach a negotiated solution or have promoted peace and co-operation pending final determination of the dispute. ${ }^{1089}$ The author believes that dispute settlement could have a significant impact on oceans governance when contentious issues of merit are submitted to the dispute settlement bodies for settlement.

Comparing chapters 2, 3 and 4, it can be concluded that most of the potential role of dispute settlement in oceans governance has not been achieved in real life. The disinclination of states to utilise the available dispute settlement mechanisms, and the inbuilt limitations and exceptions to the compulsory dispute settlement procedures in the Convention, are primarily to blame for the limited role of dispute settlement in oceans governance. Therefore, to date a match between the potential and actual roles has led to results that show the former to be greatly more than the latter. Nevertheless, the promise

\footnotetext{
${ }^{1088}$ Jon M Van Dyke "Giving Teeth to the Environmental Obligations in the LOS Convention" in Alex G Oude Elferink and Donald R Rothwell (eds) Oceans Management in the 21st Century: Institutional Frameworks and Responses (Martinus Nijhoff Publishers, Leiden, 2004) 167, 168.

${ }^{1089}$ See Klein, above n 265, 83.
} 
of dispute settlement continues to exist steadfast, ready to serve those that choose to use it.

\section{INTERNATIONAL TRIBUNAL FOR THE LAW OF THE SEA: A CRITICAL ASSESSMENT}

In a critical assessment of the performance of ITLOS, it is useful to quote a former President of the Tribunal offering an evaluation of ITLOS at a time in the recent past, that is just as applicable and relevant today: ${ }^{1090}$

The Tribunal has not yet fully developed its potential as the specialized judicial organ of the international community for the settlement of disputes concerning the interpretation or application of the Convention on the Law of the Sea.

This author cannot agree more with the above words, and argues that the Tribunal still has quite a way to go in streamlining its emergent jurisprudence to realise its potential as a specialised judicial organ in global ocean affairs. Perhaps equally as important is its need to make its decisions more attuned to present day developments worldwide, and to give additional focus on the environmental aspects of good oceans governance. As Donald Rothwell has written: ${ }^{1091}$

[In] an era when the cost and effectiveness of international institutions is increasingly under scrutiny, the Tribunal can ill afford to have its jurisdiction and effectiveness questioned at such an early stage in its operational life. This is something, however, over which the Tribunal will have little control. Its only practical response is to completely and efficiently go about its tasks so as to encourage confidence in its capacity, thereby attracting greater support for its role.

From the developments since the entry into force of the LOSC, it is increasingly becoming clear that the positive predictions that commentators had made about the future caseload of the Tribunal are far from being fulfilled. For example, Ted McDorman had written - "[it] is anticipated that the specialized ocean expertise of the LOS Tribunal will

\footnotetext{
1090 Judge Dolliver Nelson, President of ITLOS (Statement to the General Assembly of the United Nations on the Commemoration of the $20^{\text {th }}$ Anniversary of the Opening for Signature of the 1982 United Nations Convention on the Law of the Sea, New York, 9 December 2002) <http://www.itlos.org/> (last accessed 14 September 2005) para 31.

1091 "Building on the Strengths and Addressing the Challenges", above n 275, 148.
} 
increase the willingness of disputants to bring their ocean conflicts to the Tribunal."1092 Today, the Tribunal remains under-utilised, and year after year makes its standard appeal before the annual meeting of states parties to the LOSC requesting states to choose ITLOS under Article 287 as preferred dispute settlement body. ${ }^{1093}$

There is also plenty of merit in believing that ITLOS "will be able to live up to the community expectations only when litigants make full use of it." ${ }^{1094}$ But it is worth reflecting at the same time that, if the Tribunal is not seen by states as a body that propounds the law giving balanced and well reasoned decisions, it would not be seeing a lot of cases even though it "remains ready, to resolve a much wider range of disputes concerning the interpretation and application of the Convention."1095

ITLOS seems to have its eye specifically on maritime boundary delimitation cases. ${ }^{1096}$ The fulfilment of this enthusiastic wish does not appear to be easy to attain given the fact that ITLOS is clearly in competition with other modes of international dispute settlement. This is especially pertinent in comparison with the ICJ, which has a proven track record in the settlement of maritime boundary disputes, and continues to exercise a monopoly in this area of contentious jurisdiction even to this date. Take for example the maritime delimitation case brought by Romania against Ukraine in ICJ under a Treaty on Relations of Co-operation and Good-Neighbourliness, and its Additional Agreement, both of which came into force on 22 October 1997. ${ }^{1097}$ It is noteworthy that this case was instituted in ICJ on 16 September 2004, at a time when the

\footnotetext{
1092 Ted McDorman "Dispute Settlement and the Law of the Sea with Special Reference to the Aegean Sea" in in Aldo Chircop, Andre Gerolymatos and John O Iatrides (eds) The Aegean Sea After the Cold War: Security and Law of the Sea Issues (Macmillan Press Ltd, London, 2000) 225, 236 ["Dispute Settlement and the Law of the Sea with Special Reference to the Aegean Sea"].

${ }^{1093}$ See Reports of the Meeting of States Parties to the 1982 United Nations Convention on the Law of the Sea from 1994 onwards <http://www.un.org/Depts/los/meeting_states_parties/SPLOS_documents.htm> (last accessed 14 September 2005).

1094 Judge Dolliver Nelson, President of ITLOS (Statement on Agenda Item 25 (a) at the Plenary of the Fifty-Seventh Session of the United Nations General Assembly, New York, 10 December 2002) $<$ http://www.itlos.org/> (last accessed 14 September 2005) para 12.

${ }^{1095}$ Judge Dolliver Nelson, President of ITLOS (Statement on the Report of the Tribunal at the Fifteenth Meeting of States Parties to the Convention on the Law of the Sea, New York, 16 June 2005) $<\mathrm{http} / / /$ www.itlos.org/> (last accessed 14 September 2005) para 14.

${ }^{1096}$ Judge Dolliver Nelson at the Fifteenth Meeting of States Parties to the Convention on the Law of the Sea, above n 1095.

${ }_{1097}$ ICJ Press Release 2004/ $31 \quad(16 \quad$ September 2004) <http://www.icjcij.org/icjwww/idocket/iru/iruframe.htm $>$ (last accessed 14 September 2005).
} 
Tribunal had been long established and its docket was also free. ${ }^{1098}$ Keith Highet's prediction appears to be coming true that the newly instituted "unseasoned" Tribunal being "seemingly divorced from the settled jurisprudence of the International Court, may be a deterrent to its selection by States Parties." 1099

As Lowe and Churchill have noted, it would be regrettable if a specialised international tribunal such as ITLOS, drawing on the legal knowledge and wisdom from states all over the world, is merely confined within its residual jurisdiction of prompt release and provisional measure cases, as it presently is. ${ }^{1100}$ It would not be desirable if the Tribunal were simply left idle and allowed to waste in disuse, after all the efforts that went into its creation, and all the resources that are being expended in keeping it running. Indeed, "[it] would be a welcome development if a major international case were to be put before the Tribunal." 1101

There is no disputing the fact that the Tribunal has been making a continued and significant contribution to the peaceful settlement of international disputes under the LOSC, ${ }^{1102}$ and this has been revealed in chapter 3 and 4 . As has been clearly reiterated by the UN General Assembly in its $59^{\text {th }}$ Session, the Tribunal plays an important role and is an authority concerning the interpretation and application of the Convention, and the implementing agreements. ${ }^{1103}$ There are sound reasons to believe that the Tribunal has already proved itself to be successful in its internal organisation as well as in its primary tasks to settle disputes concerning the interpretation and application of the LOSC, and related agreements. ${ }^{1104}$ However, seen in the light of the implications resulting from the Tribunal's prompt release jurisprudence, the same cannot be said for its role in

\footnotetext{
${ }^{1098}$ Both Romania and Ukraine are States that have ratified the LOSC. However, Ukraine has submitted a Declaration under Art 298 of the Convention stating that it does not accept, inter alia, the compulsory procedures entailing binding decisions for the consideration of disputes relating to sea boundary delimitations. <http://www.un.org/Depts/los/convention_agreements/convention_declarations.htm> (last accessed 14 September 2005).

${ }^{1099}$ Highet, above n 263, 775.

${ }^{1100}$ Vaughan Lowe and Robin Churchill "International Tribunal for the Law of the Sea: Survey for 2001" (2002) 17 (4) IJMCL 463, 484

${ }^{1101}$ Lowe and Churchill, above $\mathrm{n}, 484$.

1102 UNGA Resolution 59/24 (4 February 2005) A/Res/59/24 para 18.

${ }^{1103}$ UNGA Resolution 59/24, above n 1102.

${ }^{1104}$ Barbara Kwaitkowska "The Future of the Law of the Sea Tribunal in Hamburg" in Wybo P Heere (ed) International Law and the Hague's 750 ${ }^{\text {th }}$ Anniversary (TMC Asser Press, The Hague, 1999) 417, 418 420. See also Gunther Jaenicke "The Interpretation of the Law of the Sea Convention in the Jurisprudence of the International Tribunal for the Law of the Sea" in Nisuke Endo and others (eds) Liber Amicorum Judge Shigeru Oda (vol 1, Kluwer Law International, The Hague, 2002) 683, 695.
} 
promoting the environmental and conservation goals of oceans governance as aimed under the LOSC. ${ }^{1105}$

In sum, while it is only fair to give credit to the Tribunal for good work done by it so far, it is also just to point out, with due respect, some of the shortcomings in its jurisprudence. It can be expected that the Tribunal will in the forthcoming years develop its jurisprudence more consistently and in keeping with the goals of oceans governance.

\section{RELUCTANCE OF STATES TO UTILISE FORMAL MEANS OF DISPUTE SETTLEMENT}

There are many strategies that states employ to resolve inter-state disputes, and though litigation is one of them, it is certainly not the most popular. ${ }^{1106}$ It is understood that negotiation is still one of the basic means of settling international disputes peacefully. ${ }^{1107}$ Compared to adjudication, negotiation allows the parties to retain more control over their dispute, whereas international adjudication resulting in a court's decision takes the dispute out of the hands of the parties, and is therefore generally avoided. ${ }^{1108}$ However, international adjudication continues to occupy a prominent place

\footnotetext{
${ }^{1105}$ See generally Howard S Schiffman "The Dispute Settlement Mechanism of UNCLOS: A Potentially Important Apparatus for Marine Wildlife Management” (1998) 1 (2) JIWLP 293, 306.

${ }^{1106}$ Christine Chinkin and Romana Sadurska "The Anatomy of International Dispute Resolution" (1991) 7 Ohio St J Disp Resol 39, 54. On the reluctance of states to litigate, see Gerald Fitzmaurice "The Future of Public International Law and of the International Legal System in the Circumstances of Today" in Institut de Droit International Livre du Centenaire 1873-1973: Evolution et Perspectives du Droit International (S Karger, Basel, 1963) 276; Oscar Schachter "International Law in Theory and Practice: General Course in Public International Law" (1982) 178 Recueil des Cours, 207 - 211; Ram Prakash Anand "Role of International Adjudication" in Leo Gross (ed) The Future of the International Court of Justice (vol 1, Oceana Publications, (Dobbs Ferry) New York, 1976) 1, 3.

1107 David Anderson "Negotiation and Dispute Settlement" in Malcolm Evans (ed) Remedies in International Law - The Institutional Dilemma (Hart Publishing, Oxford, 1998) 111, 112.

${ }^{1108}$ International Dispute Settlement, above n 334, 17; Andrew T Guzman "The Cost of Credibility: Explaining Resistance to Interstate Dispute Resolution Mechanisms" (2002) 31 J Legal Stud 303, 307. For a detailed enquiry explaining the reluctance of states to utilise adjudication for dispute settlement, see Richard B Bilder "International Dispute Settlement and the Role of Adjudication" (1987) 1 Emory J Intl Dispute Res 131. See also James Leslie Brierly "The Judicial Settlement of International Disputes" in Hersch Lauterpacht and C H M Waldock (eds) The Basis of Obligation in International Law and Other Papers by the Late James Leslie Brierly (Oxford University Press, Oxford, 1958) 93.
} 
in the world, and various theories and arguments have been advanced to explain their success and need. ${ }^{1109}$

Sohn has asserted that the present problem with international dispute settlement, and certainly that in the law of the sea, is not a lack of means but a general reluctance of states to use them. ${ }^{1110}$ Taking the Tribunal as a case in point, it is worth noting that since its inception, though its Registry received many requests for information on the institution of prompt release cases, often cases were not brought to the Tribunal, as "negotiations between parties had proved successful." 1111 Similarly Tullio Treves suggests that "NGO pressure and diplomatic considerations" explain why certain prompt release cases do not enter the Tribunal's docket. ${ }^{1112}$

Sometimes arbitration has greater appeal to states and has often been utilised to deal with non-legal political or technical disputes. ${ }^{1113}$ Nevertheless, the reluctance of states to utilise formal dispute settlement mechanisms also extends to arbitration, perhaps sometimes to a greater degree than adjudication. This is probably because there is an alleged confusion about the role of arbitration, whether it is negotiatory or adjudicatory. ${ }^{1114}$ Arbitration is also perceived as a mere supportive dispute settlement

${ }^{1109}$ See Eric A Posner and John C Yoo "A Theory of International Adjudication" (2004) International Legal Studies Working Paper Series, Paper 1, available at $<\mathrm{http} / /$ repositories.cdlib.org/ils/wp/1> (last visited 15 November 2005); Eric A Posner and John C Yoo "Judicial Independence in International Tribunals" (2005) 93 Cal L Rev 1; Laurence R Helfer and Anne-Marie Slaughter "Why States Create International Tribunals: A Response to Professors Posner and Yoo" (2005) 93 Cal L Rev 899; Eric A Posner and John C Yoo "Reply to Helfer and Slaughter" (2005) 93 Cal L Rev 957; Laurence R Helfer and Anne-Marie Slaughter "Toward a Theory of Effective Supranational Adjudication" (1997) 107 Yale L J 273; Ian Brownlie "Why Do States Take Disputes to the International Court?" in Nisuke Endo and others (eds) Liber Amicorum Judge Shigeru Oda (vol 2, Kluwer Law International, The Hague, 2002) 829.

1110 "The Future of Dispute Settlement", above n 202, 1131.

1111 Judge Dolliver Nelson, President of ITLOS (Statement on the Report of the Tribunal at the Fifteenth Meeting of States Parties to the Convention on the Law of the Sea, New York, 16 June 2005) $<\mathrm{http} / / / \mathrm{www}$. itlos.org/> (last accessed 14 September 2005) para 10.

1112 "Flags of Convenience Before the Law of the Sea Tribunal", above n 609, 185.

${ }^{1113}$ See Louis B Sohn "The Function of International Arbitration Today" (1963) I 108 Recueil des Cours 1; Karin Oellers-Frahm "Arbitration - A Promising Alternative of Dispute Settlement under the Law of the Sea Convention" (1995) 55/2 ZaöRV 457.

${ }^{1114}$ See J L Simpson and Hazel Fox International Arbitration: Law and Practice (Stevens, London, 1959) 3. 
mechanism rather than a core one. ${ }^{1115}$ Though many treaties provide for arbitration in the event of a dispute, the actual use of arbitration has remained quite less. ${ }^{1116}$

As will be seen later in this chapter, states will need to realise the potential of the LOSC dispute settlement procedures, so as to enable them to play their role in oceans governance. The continued reluctance of states to utilise the dispute settlement procedures can significantly ruin the prospects of dispute settlement to play a role in oceans governance.

\section{LIMITATIONS AND OPTIONAL EXCEPTIONS TO COMPULSORY DISPUTE SETTLEMENT PROCEDURES}

There are a few limitations and exceptions to the operation of the compulsory dispute settlement procedures under the Convention, and these have been discussed in part I of chapter $3 .^{1117}$ The acceptance of the provisions on dispute settlement by many participants at UNCLOS III was conditional upon the inclusion of certain exceptions to the operation of the compulsory dispute settlement machinery. ${ }^{1118}$ These limitations are significant not only because they played an integral role in the universal acceptability of the "package deal" that the LOSC is, but also because they limit the scope of the dispute settlement mechanisms of the Convention, and hence curtail their chances to contribute to oceans governance.

It is true that the scope of the dispute settlement mechanisms under the Convention has been reduced considerably by the limitation and optional exceptions, and these have been heavily criticised. ${ }^{1119}$ Natalie Klein has asserted that the applicability of

\footnotetext{
1115 Georgios I Zekos “Arbitration as a Dispute Settlement Mechanism Under UNCLOS, the Hamburg Rules, and WTO.” (2002) 19 (5) J Intl Arb 497, 498 - 499.

1116 See United Nations Secretariat Systematic Survey of Treaties for the Pacific Settlement of International Disputes (Lake Success, New York, 1948). For some of the possible reasons for the reluctance of states to engage in arbitration, see M C W Pinto "The Prospects for International Arbitration: Inter-State Disputes" in A H A Soons (ed) International Arbitration: Past and Prospects (Martinus Nijhoff Publishers, Dordrecht, 1990) 63, 84.

${ }^{1117}$ For a critical examination of the limitations and optional exceptions, see John King Gamble Jr "The 1982 UN Convention on the Law of the Sea: Binding Dispute Settlement?"(1991) 9 B U Intl L J 39.

1118 Virginia Commentary, above n 374, 87.

1119 "Dispute Settlement Prospects in the Law of the Sea", above n 978, 863; "Some Reflections on the Dispute Settlement Clauses in the United Nations Convention on the Law of the Sea", above n 978, 651;
} 
the compulsory part of the dispute settlement mechanisms of the LOSC is rather limited given the limitations and optional exceptions to the operation of Section $2 .{ }^{120}$ The author contends that since the LOSC "is a complex document, embodying many ambiguous compromises, some conflicting provisions and quite a few clauses requiring further elaboration in the future", ${ }^{1121}$ the chances of inter-state misunderstandings and disputes regarding the oceans remain quite high. Hence, if states were to change their present attitude towards third-party dispute settlement and invoke the procedures under Part XV where suitable, ${ }^{1122}$ the dispute settlement mechanisms under the Convention would be able to play a more prominent role in the future.

Had it not been for the exceptions, a wide range of important oceans disputes would be subject to determination under the compulsory dispute settlement procedures. Arguably, being seized of any such major dispute, a dispute settlement body would have been able to have a significant influence on oceans governance.

\section{A BETTER FUTURE FOR DISPUTE SETTLEMENT IN OCEANS GOVERNANCE}

Some of the main ways in which dispute settlement under the LOSC can contribute to oceans governance had been identified in part IV of chapter 2. However, in reality, a few of them have not been realised so far. Broadly, these are - (i) management of multiple ocean use conflicts, (ii) maritime boundary delimitation, (iii) strengthening of regimes and institutions, and (iv) unification of the substantive legal provisions of the Convention.

Looking into the future optimistically, it is possible to anticipate a greater actual role of dispute settlement in oceans governance, and see some of the above goals

\footnotetext{
Jorge R Coquia "Settlement of Disputes in the UN Convention of the Law of the Sea" (1985) 25 (2) Indian J Intl L 171, 188.

${ }^{1120}$ Klein, above n 265, 225.

${ }^{1121}$ Louis B Sohn "The Role of Arbitration in Recent International Multilateral Treaties" (1983) 23 Va J Intl L 171, 180.

${ }^{1122}$ See P W Birnie "Legal Techniques of Settling Disputes: The 'Soft Settlement' Approach" in William E Butler (ed) Perestroika and International Law (Martinus Nijhoff Publishers, Dordrecht, 1990) 177, 191. Birnie concludes that the best technique for settling a legal dispute will vary according to the circumstances of a case.
} 
fulfilled. This is clearly possible as demonstrated by gradually increasing use of Annex VII arbitral tribunals for settling maritime boundary disputes in the recent past, as discussed in part IV of chapter 3. The recourse to the residual jurisdiction of ITLOS for prompt release disputes and provisional measures would probably continue at the same frequency if not higher. An increased use of ITLOS is also anticipated as the jurisdiction of SDC is invoked when private entities and ISA appear as disputants before it. This can be foreseen as seabed operations increase and commercial exploitation of seabed resources improve.

On the pessimistic side, if childhood shows the man and morning shows the day, ${ }^{1123}$ the jurisprudence generated by the dispute settlement procedures so far does not forebode very bright prospects for LOSC dispute settlement in the future. Though the world has witnessed some major changes in attitudes of some states towards judicial modes of dispute settlement over time, especially since World War II ${ }^{1124}$ and the Cold War, ${ }^{1125}$ there can be little reason to anticipate any radical change in the attitude of states towards judicial modes of dispute settlement, as possible under Part XV of the Convention.

As has been seen in part II of this chapter, states have always preferred to use informal means to settle their disputes whereby they retain maximum control over the outcome of the dispute settlement process. Ted McDorman has argued that, despite the availability of a wide range of options for the settlement of oceans disputes, states have made little use of them, and therefore third-party adjudication has contributed little to oceans governance. ${ }^{1126} \mathrm{He}$ has further argued that though the 1900s' orthodoxy of state

\footnotetext{
${ }^{1123}$ John Milton "Paradise Regained - Book IV" in The Poetical Works of Milton (vol 2, Printed for the Booksellers, London, 1790) 71.

${ }^{1124}$ Edward McWhinney "Judicial Settlement of Disputes: Jurisdiction and Justiciability" (1990 II) Recueil des Cours 19, 19 - 24; Wojciech Góralczyk "Changing Attitudes of Central and Eastern European States Towards the Judicial Settlement of International Disputes" in Daniel Bardonnet (ed) The Peaceful Settlement of International Disputes in Europe: Future Prospects (Martinus Nijhoff Publishers, Dordrecht, 1991) 477. See also G G Shinkaretskaia "International Adjudication Today in the View of a Soviet International Lawyer" in William E Butler (ed) Perestroika and International Law (Martinus Nijhoff Publishers, Dordrecht, 1990) 245; Galina G Shinkaretskaya "International Arbitration in the External Policy of the Soviet Union" in Anthony Carty and Gennady Danilenko (eds) Perestroika and International Law: Current Anglo-Soviet Approaches to International Law (Edinburgh University Press, Edinburgh, 1990) 110.

${ }^{1125}$ See generally Paul C Stern and Daniel Druckman (eds) International Conflict Resolution After the Cold War (National Academy Press, Washington DC, 2000).

1126 “Global Ocean Governance and International Adjudicative Dispute Resolution", above n 31, 257.
} 
independence in respect of oceans governance is changing, international adjudication will continue to play a limited role in oceans governance. ${ }^{1127}$

Nevertheless, though historically dispute settlement, particularly third-party adjudication, has played a limited role in oceans governance, its potential for a greater role in the future cannot be ruled out in light of its many advantages. ${ }^{1128}$ The author views the potential of dispute settlement in oceans governance optimistically, and believes that, given the fulfilment of certain conditions, such potential can turn into reality. These conditions have been laid down in the following paragraphs.

\section{A Realising the Potential of Dispute Settlement Bodies}

One of the major ways in which the role of dispute settlement in oceans governance can be achieved in reality is by states realising and giving credence to the potential of dispute settlement bodies. As a case in point, states have to realise the potential of ITLOS as a judicial dispute settlement body where a panel of their choice can be created to hear the dispute. This can be likened to the procedure of panel selection as under arbitration procedures. To cite an example, under Article 15(2) of the Statute of the Tribunal, Special Chambers may be created to deal with a dispute at the request of the parties, and the Tribunal with the approval of the parties determines the composition of such chambers. ${ }^{1129}$ Ad hoc Chambers can also be formed within SDC, and parties can even appoint an ad hoc Judge ${ }^{1130}$ to it in case they are unhappy about its composition as determined by SDC. ${ }^{1131}$

1127 "Global Ocean Governance and International Adjudicative Dispute Resolution", above n 31, 257.

${ }^{1128}$ For a list of some of advantages of adjudication in particular, see Richard B Bilder "International Third Party Dispute Settlement" (1989) 17 Denv J Intl L \& Poly 471, 489; Manfred Lachs "Arbitration and International Adjudication" in A H A Soons (ed) International Arbitration: Past and Prospects (Martinus Nijhoff Publishers, Dordrecht, 1990) 37, 40.

${ }^{1129}$ LOSC, art 15(2) of Annex VI of the LOSC.

${ }^{1130}$ For a discussion on the circumstances under which an ad hoc Judge may be appointed to ITLOS, see Gudmundur Eiriksson "The Working Methods of the International Tribunal for the Law of the Sea" in Myron H Nordquist and John Norton Moore (eds) Oceans Policy: New Institutions, Challenges and Opportunities (Kluwer Law International, The Hague, 1999) 111, 128.

${ }^{1131}$ LOSC, art 36(1) and art 36(2) of Annex VI. 
There are similar possibilities of appointing ad hoc Judges to Chambers of ICJ. ${ }^{1132}$ States should also value and utilise dispute settlement procedures in specific circumstances, and the role of dispute settlement in oceans governance will increase under some conditions as discussed below.

$1 \quad$ Advisory opinions

Not every decision of international courts and tribunals is binding and states unwilling to bring delicate sovereignty issues out for adjudication could seek advisory opinions from ICJ and ITLOS. ${ }^{1133}$ Advisory opinions help "to clarify the law, to remove ambiguities and to provide guidance for future behaviour of the parties." "1134 Such advisory opinions may be sought by states to clarify the compatibility of their domestic legislation with established international law such as that found in the LOSC. ${ }^{1135}$ Advisory opinions could also be useful in clarifying issues and answering previously unanswered questions that arise on account of marine technological development and scientific advancement. For example, ocean carbon dioxide $\left(\mathrm{CO}_{2}\right)$ sequestration ${ }^{1136}$ is a new technological process, the legality of which is arguably not governed by the

1132 Robert Jennings "The Difference between Conducting a Case in the ICJ and an ad hoc Arbitration Tribunal - An Inside View" in Nisuke Endo and others (eds) Liber Amicorum Judge Shigeru Oda (vol 2, Kluwer Law International, The Hague, 2002), 893, 899 - 901. For a more detailed discussion on the possibilities of establishing Chambers at ICJ and ITLOS, see Shabtai Rosenne "The International Tribunal for the Law of the Sea and the International Court of Justice: Some Points of Difference" in Renate Platzöder and Philomene Verlaan (eds) The Baltic Sea: New Developments in National Policies and International Cooperation (Martinus Nijhoff Publishers, The Hague, 1996) 200, 212 - 213.

${ }^{1133}$ On the advisory jurisdiction of the ICJ, see Dharma Pratap The Advisory Jurisdiction of the International Court (Oxford University Press, London, 1972); Kenneth James Keith The Extent of the Advisory Jurisdiction of the International Court of Justice (A W Sijthoff, Leiden, 1971).

1134 "Peaceful Settlement of Disputes", above n 299, 5.

${ }^{1135}$ On the need to have initiatives at the international level to stimulate change at the national level, see Robert W Knecht "Coordination of Policy and Law Within Nation-States: Implications of Linkage Between National and International Political Forces in Achieving Sustainable Use of the Oceans" in Mochtar Kusuma Atmadja, Thomas A Mensah and Bernard H Oxman (eds) Sustainable Development and Preservation of the Oceans: The Challenges of UNCLOS and Agenda 21 (The Law of the Sea Institute, University of Hawaii, Honolulu, 1997) 408.

${ }^{1136}$ Ocean sequestration of $\mathrm{CO}_{2}$ is a potentially significant technique used to mitigate climate change. It is done by injecting $\mathrm{CO}_{2}$ into the ocean water through a land or sea-based source or piping $\mathrm{CO}_{2}$ into ocean water from an on-shore facility such as a power plant or industrial facility or injected into the seabed via pipeline from the land or sea. See Jason Heinrich "Legal Implications of Ocean $\mathrm{CO}_{2}$ Storage" (2002) Working Paper, Laboratory for Energy and the Environment, Massachusetts Institute of Technology, available at $<\mathrm{http} / / /$ sequestration.mit.edu/pdf/Legal_Implications_Ocean_Storage.pdf $>$ (last accessed 6 December 2005); Karen N Scott "The Day After Tomorrow: Ocean $\mathrm{CO}_{2}$ Sequestration and the Future of Climate Change" (2005) 18 Geo Intl Envtl L Rev 57. 
provisions of LOSC, though it has questionable impacts on the marine environment. ${ }^{1137}$ Purdy and Mcrory have argued that the LOSC does not directly prohibit or refer to the legality of $\mathrm{CO}_{2}$ sequestration, and unless $\mathrm{CO}_{2}$ is treated as pollution, Article 194 of the Convention cannot be invoked to control such activities. ${ }^{1138}$ Under such circumstances, SDC of the Tribunal could be requested to issue an advisory opinion based on relevant environmental impact assessments, scientific studies and the application of the precautionary principle, to develop rules governing the legality of this activity not foreseen by the drafters of the LOSC.

Though the LOSC does not entrust ICJ or other arbitral tribunals with such jurisdiction, as mentioned in the example above, SDC of the Tribunal enjoys the power to grant advisory opinions. ${ }^{1139}$ Article 138 of the Rules of the Tribunal also grants advisory jurisdiction to the full bench of ITLOS to provide advisory opinion on a legal question from an international agreement related to the purposes of the Convention. ${ }^{1140}$ Vukas referring to ITLOS in this regard suggests that: ${ }^{1141}$

[I]ts judgments, orders and advisory opinions could be source of inspiration for the adoption of new conventional rules, and a contribution to the crystallisation of new customary norms in the field of the law of the sea and in other domains of international law. Moreover, the general and vague language of some of the provisions of the [LOSC] brings the role of the Tribunal in the settlement of certain particular disputes close to the development of the law of the sea.

However, this author further believes that dispute settlement bodies such as ICJ and ITLOS, could have greater chances to contribute to oceans governance through the issuance of advisory opinions if the power to issue advisory opinions was extended to the

${ }^{1137}$ See generally James McCullagh "International Legal Control Over Accelerating Ocean Storage of Carbon Dioxide," in Bill Ormerod (ed) Ocean Storage of Carbon Dioxide: Workshop 3 - International Links and Concerns (IEA Greenhouse Gas R\&D Programme, Cheltenham, 1996) 85.

1138 Ray Purdy and Richard Mcrory "Geological Carbon Sequestration: Critical Legal Issues" (2004) Working Paper 45, Tyndall Centre for Climate Change Research, available at $<$ http://www.earthscape.org/r1/ES15586/wp45.pdf > (last accessed 6 December 2005) 17.

1139 LOSC, art191. Tullio Treves "Advisory Opinions under the Law of the Sea Convention" in M H Nordquist and J N Moore (eds) Current Marine Environmental Issues and the International Tribunal for the Law of the Sea (Kluwer Law International, The Hague, 2001) 81, 81 ["Advisory Opinions under the Law of the Sea Convention"]. For a historical discussion on the endowment of advisory jurisdiction on ITLOS, see Louis B Sohn "Advisory Opinions by the International Tribunal for the Law of the Sea or Its Seabed Disputes Chamber" in Myron H Nordquist and John Norton Moore (eds) Oceans Policy: New Institutions, Challenges and Opportunities (Kluwer Law International, The Hague, 1999) 61.

1140 “Advisory Opinions under the Law of the Sea Convention", above n 1139, 91.

1141 "Possible Role of the International Tribunal for the Law of the Sea in Interpretation and Progressive Development of the Law of the Sea", above n 23, 103. 
LOSC generally, and not limited to international agreements related to the purposes of the Convention.

Not all disputes are suited for settlement by international adjudication. However, one of the ways in which the international community could strengthen the role of dispute settlement is by submitting disputes to them for settlement. ${ }^{1142}$

Bilder has pointed to three categories of disputes that are particularly conducive to settlement by arbitration or judicial settlement - (i) those that do not involve significant national interest such as insignificant areas of maritime boundaries, (ii) those that involve difficult and complex factual or technical questions where the parties are agreeable to find a compromise solution but are unable to find a viable basis for the same, as with many ocean related disputes, (iii) those disputes that threaten to develop into breaches of peace, resort to judicial settlement may be a politically acceptable way for buying time while long-term solutions are worked out. ${ }^{1143}$ It is submitted that if states facing such disputes are willing to entrust courts and tribunals with their settlement, it could go a long way in expanding the role of dispute settlement in oceans governance.

It is also hoped that the role of dispute settlement in oceans governance will gradually increase with the passage of time ${ }^{1144}$ and growth in the world's population. Alan Dupont has linked the growth of conflict in the oceans with population growth. ${ }^{1145}$ Rapid growth in populations will lead to increased pressures on the sea and its resources, and with increasing pollution from urbanisation, will lead to overall marine

\footnotetext{
${ }^{1142}$ Richard B Bilder "Adjudication: International Arbitral Tribunals and Courts" in I William Zartman and J Lewis Rasmussen (eds) Peacemaking in International Conflict: Methods \& Techniques (United States Institute of Peace Press, Washington DC, 1997) 115, 179 [“Adjudication: International Arbitral Tribunals and Courts"].

1143 "Adjudication: International Arbitral Tribunals and Courts", above n 1142, 179.

${ }^{1144}$ See generally Samuel P Huntington "The Clash of Civilizations?" (1993) 72 (3) Foreign Affairs 22.

1145 Alan Dupont "Maritime Environmental Security" in David Wilson and Dick Sherwood (eds) Oceans Governance and Maritime Strategy (Allen \& Unwin, St Leonards (NSW), 2000) 129, 130.
} 
environmental degradation. ${ }^{1146}$ With such problems and their consequences posing as challenges to oceans governance, the possibility of disputes resulting from them is imminent. ${ }^{1147}$ Under such circumstances, the binding and compulsory dispute settlement machinery under the LOSC could be an effective tool in the management of potential conflict situations. ${ }^{1148}$

One way to strengthen international law is by encouraging states to take a more positive and proactive approach to compulsory dispute settlement by pre-selecting dispute settlement procedures for future disputes. ${ }^{1149}$ The CGG has argued that such a practice accelerates recourse to third-party dispute settlement procedures based on international law, and also provides an incentive for reaching agreement on the substance of the dispute prior to any hearing. ${ }^{1150}$ Pre-selection of dispute settlement mechanisms under Article 287 of the Convention is a practical option that states parties to the Convention could exercise, but hardly do. The General Assembly Resolutions each year repeatedly encourage states that have not made a declaration under Article 287, to do so. ${ }^{1151}$ The President of ITLOS often makes a similar appeal to the states parties to the Convention in suitable forums, though in self-serving terms, urging them to choose ITLOS as the forum for the settlement of their law of the sea disputes. ${ }^{1152}$

\footnotetext{
${ }^{1146}$ See Dupont, above n 1145, $131-135$.

1147 Dupont opines that there is an almost circular relationship between population growth, food security, ecological stress and conflict. Dupont, above n 1145, 132.

${ }^{1148}$ For the potential utility of the LOSC dispute settlement machinery, see J Ashley Roach "Dispute Settlement in Specific Situations" (1995) 7 Geo Intl Envtl L Rev 775; Christin Chinkin "Dispute Resolution in the Law of the Sea: Regional Problems and Prospects" in J Crawford and D R Rothwell (eds) The Law of the Sea in the Asian Pacific Region (Kluwer Academic Publishers, The Hague, 1995) 237, 237. 1149 Our Global Neighbourhood, above n 51, 308 - 309, 318. Contrast Shigeru Oda "The Compulsory Jurisdiction of the International Court of Justice: A Myth? A Statistical Analysis of Contentious Cases" (2000) 49 ICLQ 251, 264.

1150 Our Global Neighbourhood, above n 51, 318.

${ }_{1151}^{115}$ See for example UNGA, A/RES/59/24 (4 February 2005) para 20.

${ }^{1152}$ See for example Judge Rüdiger Wolfrum, President of ITLOS (Statement to the Informal Meeting of Legal Advisors of Ministries of Foreign Affairs, New York, 24 October 2005) $<$ http://www.itlos.org/news/statements/President.Wolfrum.24.10.05.E.pdf $>$ (last accessed 4 December 2005) para 6.
} 


\section{B Political Will and Confidence in Dispute Settlement}

If the LOSC was meant to be a "constitution" or the legal backbone of oceans governance, dispute settlement mechanisms established under it, such as ITLOS, are faced with the task adding the flesh by giving clear guidance on issues of disputes and prioritising conflicting interests, where necessary. However, the dispute settlement mechanisms will not be capable of fleshing out the details for good oceans governance all on their own. They will need to have the confidence of states that would utilise them under appropriate circumstances where dispute settlement could have the maximum impact on oceans governance. ${ }^{1153}$ Dispute settlement procedures under the LOSC will be able to contribute to oceans governance only as far as states parties allow them to. The theory of consent is intrinsically germane to international dispute settlement, and even 'compulsory' jurisdiction is voluntary. ${ }^{154}$

Howard Schiffman writes: ${ }^{1155}$

[T] he ultimate test of whether UNCLOS dispute settlement makes a big splash or barely a ripple will not only depend on the volume of cases that are brought before it. Rather, the true measure of its success will depend on the confidence that it can engender in states that utilize it. As states start to participate in UNCLOS dispute settlement, they will need to know that their interests and objectives, indeed their very inducements for joining the treaty in the first place, will be furthered. Like any system of justice it must have the confidence of those it serves.

Having considered the above view, it seems to the author that the role of dispute settlement in oceans governance is like a Catch $22^{1156}$ situation. If states do not utilise the dispute settlement provisions in the LOSC, those provisions would not even have a

\footnotetext{
1153 "Dispute Settlement and the Law of the Sea with Special Reference to the Aegean Sea", above n 1092, 237; David H Anderson "The Role of ITLOS as a Means of Dispute Settlement under UNCLOS" in Andree Kirchner (ed) International Marine Environmental Law: Institutions, Implementation And Innovations (Kluwer Law International, The Hague, 2003) 19. See generally Peter H Kooijmans "The International Court of Justice: Where Does it Stand?" in A S Muller, D Raič and J M Thuránszky (eds) The International Court of Justice: Its Role after 50 Years (Martinus Nijhoff Publishers, The Hague, 1997) 407, 418.

${ }^{1154}$ International Dispute Settlement, above n 334, 292; Erik Franckx "Pacta Tertiis and the Agreement for the Implementation of the Straddling and Highly Migratory Fish Stocks Provisions of the United Nations Convention on the Law of the Sea" (2000) 8 Tul J Intl \& Comp L 49, 53.

1155 "UNCLOS and Marine Wildlife Disputes: Big Splash or Barely a Ripple?", above n 934, 277.

${ }^{1156}$ Joseph Heller Catch - 22 (Corgi Books, London, 1964). The logic behind Catch -22 is that it describes a general situation in which A must have been preceded by B, and B must have been preceded by A., where either A or B must come into being first.
} 
chance to contribute to oceans governance. Again, if the dispute settlement mechanisms do not gain the confidence of states by making a real contribution in the settlement of ocean disputes and in oceans governance generally, states would be loath to have recourse to them. Although the dispute settlement provisions of the Convention are caught in an apparent Catch 22 situation, it is submitted that states largely hold the key to unravel their potential.

To a considerable extent, it is also incumbent upon the dispute settlement machinery, when activated, to act in a judicious manner in the spirit and the directions given by the Convention. ${ }^{157}$ With an increased confidence reposed on dispute settlement procedures, and the dispute settlement bodies themselves deciding issues on an objective analysis of the law, the author foresees an actual and important role for dispute settlement in oceans governance. In the alternative, even if the dispute settlement machinery were not directly utilised, it would continue to be most effective and pivotal to the LOSC by aiding dispute prevention among states, and encouraging compliance with the norms of good oceans governance. ${ }^{1158}$

As an authority on oceans issues, IWCO considered that the peaceful uses of the oceans are of great importance in the present world, and recognised the importance of prevention and settlement of disputes regarding maritime boundaries and ocean resources. ${ }^{1159}$ Among its many conclusions, IWCO submitted that an important step towards effective oceans governance was to utilise the mechanisms for dispute settlement better. ${ }^{1160}$

Successful dispute settlement not only requires robust legal systems but political will and diplomatic trade-offs in a pervading spirit of co-operation. ${ }^{1161}$ The political will must exist not only to utilise dispute settlement procedures, but also to enforce and act upon the decisions and advice emerging from such procedures. Though it is to be

${ }^{1157}$ John E Noyes "Law of the Sea Dispute Settlement: Past, Present, and Future" (1999) 5 ILSA J Intl \& Comp L 301, 308.

${ }_{1158}$ Serdy, above $\mathrm{n} 215,721$. For more arguments on the role of dispute settlement procedures in dispute prevention, see part IV F of chapter 2.

${ }^{1159}$ UNGA, Letter dated 10 October 1997 from the Permanent Representative of Portugal to the United Nations addressed to the Secretary-General, (14 October 1997) A/52/458, para 4.

${ }^{1160}$ UNGA, Letter dated 16 October 1998 from the Permanent Representative of Portugal to the United Nations addressed to the Secretary-General, (9 October 1998) A/53/524, para 14(b).

${ }^{1161}$ See Haijiang Yang "Dispute Settlement Procedures for Foreign Merchant Ships" (2005) 20 (1) IJMCL $117,134$. 
recognised that political will is largely an intrinsic matter, there are ways in which it can be influenced to make dispute settlement procedures more acceptable. In this regard, the role of pressure groups, NGOs, ${ }^{1162}$ and even international organisations such as the $\mathrm{UN}^{1163}$ deserves a mention. As a case in point, it is interesting to note that the first case before ITLOS was referred to it upon advice from DOALOS, as revealed by the UnderSecretary-General for Legal Affairs and Legal Counsel of the United Nations. ${ }^{1164}$

The presence of domestic and international pressure would also be essential to ensure that implementation of decisions by the dispute settlement bodies are effectively carried out in the best manner. ${ }^{1165}$ It has been argued elsewhere that success of community pressure in bringing about a desired result following international dispute settlement depends largely upon the expectations of the parties and the public. ${ }^{1166}$ It is generally seen that, in the case of a formally binding decision, there is a strong community expectation that the parties will adhere to it and this in turn creates increased pressure upon the parties to actually adhere to the decision. ${ }^{1167}$ With the adherence to and the abidance with the findings and decisions emerging from the use of dispute settlement procedures, community pressure can help give expression to the role of dispute settlement in oceans governance.

\section{HIGH HOPES?}

In the assessment of dispute settlement mechanisms, particularly those involving third parties, it needs to be reiterated that their primary function is to decide issues

\footnotetext{
${ }^{1162}$ See Lee A Kimball "Major Challenges of Ocean Governance: The Role of NGOs" in Davor Vidas and Willy Østreng (eds) Order for the Oceans at the Turn of the Century (Kluwer Law International, The Hague, 1999) 389, 391.

${ }^{1163}$ See Roy S Lee "Towards a More Proactive System of Dispute Settlement" in Nisuke Endo and others (eds) Liber Amicorum Judge Shigeru Oda (vol 2, Kluwer Law International, The Hague, 2002) 923.

${ }^{1164}$ Hans Corell "Future Role of the United Nations in Ocean and Law of the Sea" in Myron H Nordquist and John Norton Moore (eds) Oceans Policy: New Institutions, Challenges and Opportunities (Kluwer Law International, The Hague, 1999) 15, 21.

${ }^{1165}$ See Silk, above $\mathrm{n}, 818$. On the implementation and enforcement of decisions of international courts, see Rüdiger Wolfum "Implementation of Decisions of International Courts" in M H Nordquist and J N Moore (eds) Current Marine Environmental Issues and the International Tribunal for the Law of the Sea (Kluwer Law International, The Hague, 2001) 103. See also P Chandrasekhara Rao "The International Tribunal for the Law of the Sea: An Evaluation" in Nisuke Endo and others (eds) Liber Amicorum Judge Shigeru Oda (vol 1, Kluwer Law International, The Hague, 2002) 667, 680.

${ }^{1166}$ Craik, above n 140, 561.

${ }^{1167}$ Craik, above n 140, 561.
} 
presented to it by states parties involved in a dispute, ${ }^{1168}$ preventing breaches of peace from conflicts between states, and interpreting and applying rules of international law, both customary and conventional. ${ }^{169}$

It is not being suggested that the law of the sea, or much less, the dispute settlement systems under the LOSC are the panacea to all problems of oceans governance faced by humankind. Using the words of James Brierly, "[1]aw, after all, is only a means to an end, and that end is to assist in solving the problems of the society in and for which it exists." ${ }^{1170}$ Or as Wilfred Jenks opines referring to international adjudication, it "is not the sovereign remedy to all our ills." ${ }^{1171}$ Dispute settlement options cannot contribute to oceans governance on their own. It would also not be fair to have extremely high expectations of international dispute settlement mechanisms to serve the ends of oceans governance. Compulsory dispute settlement procedures under the LOSC, applying the tenets of established international law, are a necessary but not a sufficient requirement for good oceans governance. Particularly with respect to an international court or tribunal empowered under the LOSC, words of a distinguished authority are very relevant: ${ }^{1172}$

If it were overloaded with functions not related to adjudication, its prestige might soon be dissipated. If it were expected to relieve politicians of their responsibilities, to deal with matters usually characterized as political, its authority might soon be undermined. To say that its functions must be limited is not to reduce them to insignificance; it is to preserve their significance.

Little can be achieved by way of oceans governance initiatives without participation and co-operation among nations not only in the utilisation of dispute settlement procedures, but also in implementing and enforcing the existing plethora of laws. Therefore, the dispute settlement provisions of the LOSC should be left to fulfil their primary mandate that they had been entrusted with: that of maintaining international peace through justice and equity when approached with disputes involving the

\footnotetext{
1168 Manley O Hudson International Tribunals: Past and Future (Carnegie Endowment for International Peace and Brookings Institution, Washington DC, 1944) 236.

1169 "The Future of Dispute Settlement", above n 202, 1121.

${ }^{1170}$ James Leslie Brierly "The Shortcomings of International Law" (1924) 5 BYBIL 4, 8.

${ }^{1171}$ Clarence Wilfred Jenks The Prospects of International Adjudication (Steven, London, 1964) 771.

${ }^{1172}$ Hudson, above n 1168, 249.
} 
interpretation or application of the law. ${ }^{1173}$ In carrying out this principal function of dispensing justice, dispute settlement procedures would lead to the objective treatment of contentious issues, and hopefully develop priorities aiding the cause of good oceans governance in some or all of the various ways as enumerated in part IV of chapter 2.

\section{CONCLUSIONS}

This chapter has demonstrated that the potential role of dispute settlement in oceans governance has not been completely realised in actual life. Parts III and IV of the chapter argued that the reluctance of states to utilise formal dispute settlement procedures and the limitations and optional exceptions to the compulsory dispute settlement procedures were chiefly responsible for the limited role of dispute settlement in oceans governance so far.

A critical assessment of ITLOS in part II has revealed that, though the Tribunal's performance in the first ten years of its life has been commendable, it still needs to live up to the expectations of present day oceans governance, and bring about greater consistency in its decisions.

Part IV was devoted to crystal ball gazing about the future role of LOSC dispute settlement in oceans governance. It was recommended that states realise the potential of dispute settlement procedures in specific circumstances, amend the political will to bring relevant disputes before dispute settlement bodies, and enforce the decisions resulting from adjudication. On the fulfilment of these conditions, dispute settlement would have a greater role to play in oceans governance. However, in the end it was found worthwhile to recognise the limitations of dispute settlement procedures, and only fair not to expect dispute settlement to provide a remedy for all maladies in oceans governance.

\footnotetext{
${ }^{1173}$ See Hersch Lauterpacht "The Judicial Settlement of International Disputes" in Elihu Lauterpacht (ed) International Law: Being the Collected Papers of Hersch Lauterpacht (vol 5, Cambridge University Press, Cambridge, 2004) 72.
} 


\section{CHAPTER 6}

\section{CONCLUSIONS AND RECOMMENDATIONS}

Human life and existence on this planet has reached such a level that it is impossible for humans to continue surviving and not negatively affect the oceans. The living environment, marine or otherwise, continues to suffer at the hands of humans, directly and indirectly. ${ }^{174}$ Dire consequences have been predicted for the future of humankind and the world in general if the oceans are not governed in a sustainable manner. ${ }^{1175}$ Such a bleak future, if humankind were to see one, would be accompanied by nations playing the blame game and giving rise to increased disputes relating to the oceans.

A lot of hopes and aspirations had gone into the creation and incorporation of the dispute settlement provisions in the LOSC. So much so that it was said that "[t]he stability of the new regime for the oceans, which is likely to encompass many novel principles and institutions, will depend to a large extent on the establishment and effective functioning of the [dispute] settlement procedures." 1176

In chapter 2, an examination of the meanings of governance and its links with law and dispute settlement served as the background for the analysis of the connotations of oceans governance, and its connections with law and dispute settlement. This chapter revealed plenty of potential for dispute settlement to play a role in oceans governance in diverse ways, including the (i) enforcement and implementation of the Convention, (ii) maintenance of the integrity of the principles governing the Convention, (iii) unification of the substantive legal provisions of the Convention, (iv) provision of protection from abuse, (v) regulation and allocation of resources, (vi) maritime boundary delimitation, (vii) strengthening of regimes and institutions, (viii) interpretation of the law and development of rules, (ix) facilitation of cooperation, (x) reduction of tension and

\footnotetext{
${ }^{1174}$ See Paul and Anne Ehrlich Extinction: The Causes and Consequences of the Disappearances of Species (Random House, New York, 1981) 103 - 176.

${ }^{1175}$ See Anne W Simon Neptune's Revenge: The Ocean of Tomorrow (Franklin Watts, New York, 1984) 177.

1176 Louis B Sohn "Towards a Tribunal for the Oceans" (1975-76) 5-6 Revue Iranienne Des Relations Internationales 247,258 .
} 
maintenance of peace, (xi) ensuring compliance with laws and norms, and (xii) management of multiple ocean use conflicts.

In chapter 3 , the thesis provided an introduction to the core dispute settlement provisions of the Convention. The next part analysed the jurisprudence emerging from the use of Part XV of the Convention and brought out those issues that the author deemed to have the maximum impact on oceans governance. The chapter largely revealed mixed results, and concluded that most points of the Part XV jurisprudence had a beneficial impact on oceans governance while some others did not. The practice of the Tribunal in discounting bonds in prompt release cases was identified as having a destructive impact on oceans governance, and leading to uncertainties among coastal states as to the nature of a reasonable bond.

It was argued that IUU fishing practices were indirectly benefiting from the prompt release jurisprudence of ITLOS. An analysis of the provisional measures cases and the subsequent judicial proceedings revealed largely beneficial developments for oceans governance, chiefly achieved through dispute settlement bodies facilitating cooperation among disputant states. An account of the cases pending under Part XV of the Convention revealed an increasing use of Annex VII tribunals in settling maritime boundary delimitation cases in recent times. The chapter also argued that, although the overall effect of the existing jurisprudence had been largely beneficial to oceans governance, the magnitude of the impact has been less significant.

Chapter 4 revealed the many levels of interaction between a dispute settlement body, ITLOS, and the developing states parties to the Convention. This chapter showed that the role of ITLOS in the oceans governance process went beyond its ordinary functions as a dispute settlement body. The various points of engagement between ITLOS and developing countries were seen as constructive elements in achieving good oceans governance. It was argued that the increased participation of developing countries in the dispute settlement process would potentially increase the opportunities for the LOSC dispute settlement procedures to be invoked. This would in turn lead to greater opportunities for dispute settlement mechanisms to play a role in oceans governance. It was also proposed that more assistance from developed countries and other sources 
would go a long way in improving the capacity of ITLOS in fostering the cause of good oceans governance in developing countries.

In chapter 5 the potential and actual contribution of dispute settlement to oceans governance was tallied, and predictions were made of the role in the future. It was reiterated that the dispute settlement machinery established under the Convention has considerable potential to make a significant contribution to oceans governance. Nevertheless, experience over the past decade of the LOSC being in force revealed a limited actual role for dispute settlement in oceans governance.

It was argued that, if states continue to demonstrate a reluctance to utilise established formal dispute settlement means such as adjudication and arbitration to settle disputes, the respective forums will not have much of a chance to contribute to oceans governance in the future. Even in circumstances where established permanent international courts and tribunals such as ICJ and ITLOS remain available to play a role outside the forte of dispute settlement, such as in their competence to issue advisory opinions, it would be regrettable if they continue to be underutilised. A critical assessment of ITLOS argued, that though it is rendering valuable service to the world in its role in oceans governance, it still has a long way to go in fulfilling its mandate. The limitations and optional exceptions to the compulsory dispute settlement procedures were also to blame for the limited role of dispute settlement in recent years. This chapter concluded making optimistic predictions about a greater role for dispute settlement in oceans governance in the future.

It is appropriate at this stage to summarise the key recommendations that have been made in various parts of the thesis for bringing out the true potential of dispute settlement in oceans governance. For strengthening the role of dispute settlement in oceans governance, a number of factors must contribute. First, concerned states and other entities must be willing to utilise the dispute settlement mechanisms to settle their disputes, and clarify grey areas of the law. Secondly, the political will must be ready to enforce and carry out any directions emerging from the dispute settlement process. Thirdly, scientific findings that measure the state of the oceans must maintain sufficient credibility in the understanding of all interested parties having a say in the oceans governance process. Finally, domestic and international pressure should be available to 
ensure that enforcement of decisions by the dispute settlement bodies are effectively carried out in the best manner possible. In conclusion, it is asserted that, given the fulfilment of the requirements stated in the above-mentioned recommendations, dispute settlement will in the future have a greater and more significant role to play in oceans governance. 


\section{APPENDIX ONE}

\section{INDEX TO ABBREVIATIONS AND ACRONYMS}

AFMA

Agreement on Privileges

AJIL

ALJ

Am Socy Intl L Proc

APJEL

Aust YBIL

Brook J Intl L

B U Intl L J

BYBIL

Cal L Rev

Cal W Intl L J

Can YIL

Cardozo L Rev

CCAMLR

C-CCAMLR

CCSBT

C-CCSBT

CGG

Chinese J Intl L

CITES

\section{CLCS}

\section{CLJ}

Colum J Transnatl L

Conn J Intl L

Convention

Cornell Intl L J

Court

Dal L J

Denv J Intl L \& Poly
Australian Fisheries Management Authority

Agreement on the Privileges and Immunities of the International Tribunal for the Law of the Sea

American Journal of International Law

Australian Law Journal

American Society of International Law Proceedings

Asia Pacific Journal of Environmental Law

Australian Yearbook of International Law

Brooklyn Journal of International Law

Boston University International Law

Journal

British Year Book of International Law

California Law Review

California Western International Law

Journal

Canadian Yearbook of International Law

Cardozo Law Review

Convention for the Conservation of Antarctic Marine Living Resources

Commission for the Conservation of

Antarctic Marine Living Resources

Convention for the Conservation of

Southern Bluefin Tuna

Commission for the Conservation of

Southern Bluefin Tuna

Commission on Global Governance

Chinese Journal of International Law

Convention on International Trade in Endangered Species of Wild Fauna and Flora

Commission on the Limits of the

Continental Shelf

Cambridge Law Journal

Columbia Journal of Transnational Law

Connecticut Journal of International Law

United Nations Convention on the Law of the Sea

Cornell International Law Journal

International Court of Justice

Dalhousie Law Journal

Denver Journal of International Law and Policy 
DOALOS

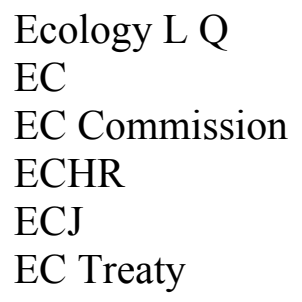

EEZ

EFP

Emory J Intl Dispute Res

Envtl L

Envtl Poly \& L

EJIL

ELQ

EPLJ

EU

Euratom Treaty

FAO

Fed L Rev

Fish Stocks Agreement

Fish Stocks Assistance Fund

Fla St J Transnatl L \& Poly

Foreign Aff

GATT

Geo Intl Envtl L Rev

Geo J Legal Ethics

Geo Wash Intl L Rev

GESAMP

Golden Gate U L Rev

Harv Intl L J

ICJ
Division for Ocean Affairs and the Law of the Sea

Ecology Law Quarterly

European Commission

Commission of the European Communities

European Court of Human Rights

European Court of Justice

Treaty Establishing the European

Community

Exclusive Economic Zone

Experimental Fishing Programme

Emory Journal of International Dispute

Resolution

Environmental Law

Environmental Policy \& Law

European Journal of International Law

Ecology Law Quarterly

Environmental and Planning Law Journal

European Union

Treaty Establishing the European Atomic Energy Community

Food and Agriculture Organization of the United Nations

Federal Law Review

Agreement for the Implementation of the Provisions of the United Nations Convention on the Law of the Sea of 10 December 1982 relating to the Conservation and Management of Straddling Fish Stocks and Highly Migratory Fish Stocks

Assistance Fund under Part VII of the Fish Stocks Agreement

Florida State Journal of Transnational Law and Policy

Foreign Affairs

General Agreement on Tariffs and Trade

Georgetown International Environmental Law Review

Georgetown Journal of Legal Ethics

George Washington International Law Review

Joint Group of Experts on the Scientific Aspects of Marine Environmental Protection

Golden Gate University Law Review

Harvard International Law Journal International Court of Justice 
ICJ Reports

ICLQ

IJMCL

ILM

ILSA J Intl \& Comp L

IMCC

IMO

Indian J Intl L

Intl Law

Intl Org

ISA

ITLOS

ITLOS Trust Fund

IUCN

IUU Fishing

IWC

IWCO

J Envtl L

$\mathrm{J}$ Intl Arb

J Intl L \& Diplo

JIWLP

J Legal Stud

J Mar L \& Com

J Min L \& Poly

KOICA

Law \& Contemp Probs

LJIL

LOSC

LPSG

Loy L A Intl \& Comp L Rev

\section{LPICT}

LPSG
Reports of Judgments, Advisory Opinions and Orders; The International Court of Justice

International \& Comparative Law Quarterly International Journal of Marine and Coastal Law

International Legal Materials

ILSA Journal of International and Comparative Law

Interministerial Maritime Control

Commission of Guinea-Bissau

International Maritime Organization

Indian Journal of International Law

International Lawyer

International Organization

International Seabed Authority

International Tribunal for the Law of the

Sea

International Tribunal for the Law of the

Sea Trust Fund

International Union for the Conservation of

Nature and Natural Resources; The World

Conservation Union

Illegal, unreported and unregulated fishing

International Whaling Commission

Independent World Commission on the

Oceans

Journal of Environmental Law

Journal of International Arbitration

Journal of International Law and

Diplomacy

Journal of International Wildlife Law \&

Policy

Journal of Legal Studies

Journal of Maritime Law and Commerce

Journal of Mineral Law and Policy

Korea International Cooperation Agency

Law and Contemporary Problems

Leiden Journal of International Law

United Nations Convention on the Law of the Sea

Lisbon Principles of Sustainable

Governance

Loyola of Los Angeles International and Comparative Law Review

Law \& Practice of International Courts and

Tribunals

Lisbon Principles of Sustainable

Governance 
Max Planck Yrbk UN L

Melb J Intl L

Melb U L Rev

Mich J Intl L

Minn L Rev

MLAANZ Journal

N C J Intl L \& Com Reg

NGO

NILR

Non-State Actors \& Intl L

Nordic J Intl L

N Y U J Intl L \& Pol

$\mathrm{NZ} / \mathrm{A}$

NZLJ

NZYIL

ODIL

OECD

OJ

OSPAR Convention

Pace Intl L Rev

Pace L Rev

PCA

PLR

RECIEL

RFMO

San Diego Intl L J

San Diego L Rev

SAYIL

SDC

Southeastern Envtl L J

SPLOS

Stetson L Rev

TAC

Tex L Rev

Trans Natl L \& Contemp Probs

Tul Envtl L J

Tul J Intl \& Comp L
Max Planck Yearbook of United Nations

Law

Melbourne Journal of International Law

Melbourne University Law Review

Michigan Journal of International Law

Minnesota Law Review

Maritime Law Association of Australia and

New Zealand Journal

North Carolina Journal of International

Law and Commercial Regulation

Non Governmental Organisation

Netherlands International Law Review

Non-State Actors and International Law

Nordic Journal of International Law

New York University Journal of International Law \& Politics

New Zealand and Australia

New Zealand Law Journal

New Zealand Year Book of International

Law

Ocean Development \& International Law

Organisation for Economic Cooperation and Development

Official Journal of the European

Communities

Convention for the Protection of the Marine

Environment of the North-East Atlantic

Pace International Law Review

Pace Law Review

Permanent Court of Arbitration

Public Law Review

Review of European Community and International Environmental Law

Regional Fisheries Management

Organisations

San Diego International Law Journal

San Diego Law Review

South African Yearbook of International Law

Seabed Disputes Chamber

South Eastern Environmental Law Journal

States Parties to the Law of the Sea

Stetson Law Review

Total Allowable Catch

Texas Law Review

Transnational Law and Contemporary Problems

Tulane Environmental Law Journal

Tulane Journal of International and Comparative Law 
Tul Mar L J

TWQ

U Det L J

UN

UNCLOS III

UNDP

UNEP

UNGA

UNTS

UQLJ

US

UWAL Rev

Va J Intl L

Va Envtl L J

Vand J Transnatl L

VMS

VUWLR

WTO

WWF

Yale L J

YIEL

ZaöRV
Tulane Maritime Law Journal

Third World Quarterly

University of Detroit Law Journal

United Nations Organization

Third United Nations Conference on the

Law of the Sea $(1973-1982)$

United Nations Development Programme

United Nations Environment Programme

United Nations General Assembly

United Nations Treaty Series

University of Queensland Law Journal

United States of America

University of Western Australia Law

Review

Virginia Journal of International Law

Virginia Environmental Law Journal

Vanderbilt Journal of Transnational Law

Vessel Monitoring System

Victoria University of Wellington Law

Review

World Trade Organization

World Wildlife Fund

Yale Law Journal

Yearbook of International Environmental Law

Zeitschrift für Ausländisches öffentliches Recht und Völkerrecht 
APPENDIX TWO

INDEX TO TABLES

TABLE - I PROMPT RELEASE CASES AT ITLOS AND BONDS

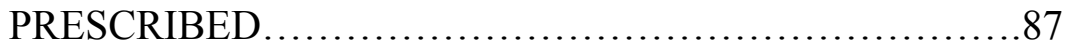

TABLE - II TIME TAKEN BY ITLOS IN DISPOSING URGENT

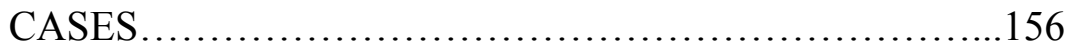

TABLE - III JUDGES OF ITLOS AND THEIR COUNTRY OF ORIGIN .................................................. 182 


\section{BIBLIOGRAPHY}

\section{TREATIES AND AGREEMENTS}

Agreement Relating to the Implementation of Part XI of the United Nations Convention on the Law of the Sea of 10 December 1982 (28 July 1994) 1836 UNTS 3.

Agreement for the Implementation of the Provisions of the United Nations Convention on the Law of the Sea of 10 December 1982 Relating to the Conservation and Management of Straddling Fish Stocks and Highly Migratory Fish Stocks (4 August 1995) 2167 UNTS 3.

Agreement on the Privileges and Immunities of the International Tribunal for the Law of the Sea (23 May 1997) 2167 UNTS 271.

Convention on the Conservation of Antarctic Marine Living Resources (1 August 1980) 1329 UNTS 47.

Convention for the Conservation of the Southern Bluefin Tuna (10 May 1993) 1819 UNTS 560.

Convention for the Protection of the Marine Environment of the North-East Atlantic (21 September 1992) (1993) 31 ILM 1312.

Convention on the Continental Shelf (29 April 1958) 499 UNTS 311.

Convention on Fishing and Conservation of the Living Resources of the High Seas (29 April 1958) 559 UNTS 285.

Convention on the High Seas (29 April 1958) 440 UNTS 11.

Convention on the Territorial Sea and the Contiguous Zone (29 April 1958) 516 UNTS 205.

General Agreement on Tariffs and Trade (30 October 1947) 55 UNTS 194.

Optional Protocol of Signature Concerning the Compulsory Settlement of Disputes (29 April 1958) 450 UNTS 169.

Settlement Agreement in the Case Concerning Land Reclamation by Singapore In and Around the Straits of Johor, (26 April 2005), available at $<$ http://www.mfa.gov.sg/internet/press/land/Settlement_Agreement.pdf $>$ (last accessed 8 December 2005).

Treaty of Amsterdam Amending the Treaty on European Union, the Treaties Establishing the European Communities and Certain Related Acts (2 October 1997) [1997] OJ C 340/1. 
Treaty Establishing the European Atomic Energy Community (25 March 1957) 298 UNTS 259.

United Nations Convention on the Law of the Sea (10 December 1982) 1833 UNTS 3.

\section{CASES}

Case Concerning Delimitation of the Maritime Boundary in the Gulf of Maine Area (Canada v United States of America) (Merits) [1984] ICJ Rep 246.

Case Concerning Maritime Delimitation and Territorial Questions between Qatar and Bahrain (Qatar v Bahrain) (Merits) [2001] ICJ Rep 40.

Case Concerning Land Reclamation by Singapore In and Around the Straits of Johor (Malaysia $v$ Singapore) (Provisional Measures) [2003] $<$ http://www.itlos.org/> (last accessed 1 December 2005).

Case Concerning Land Reclamation by Singapore In and Around the Straits of Johor (Malaysia v Singapore) [2005] <http://www.pca-cpa.org/> (last accessed 1 December 2005).

Case Concerning the Conservation of and Sustainable Exploitation of Swordfish Stocks in the South-Eastern Pacific Ocean (Chile/European Community) [2000] (last accessed 1 December 2005).

Fisheries Jurisdiction (United Kingdom v Iceland) [1974] ICJ Rep 3.

Fisheries Jurisdiction (Spain v Canada) [1995] ICJ Rep 87.

GATT, United States - Restrictions on Imports of Tuna, adopted in September 1991 (Panel Report No DS21/R), reproduced in 30 ILM 1598 (November 1991).

Handyside $v$ The United Kingdom (1976) 24 ECHR (Ser A) 49.

North Sea Continental Shelf (Federal Republic of Germany/Denmark) [1967] ICJ Rep 3.

North Sea Continental Shelf (Federal Republic of Germany/Netherlands) [1967] ICJ Rep 6.

Southern Bluefin Tuna Cases (New Zealand v Japan; Australia v Japan) (Provisional Measures) [1999] <http://www.itlos.org/> (last accessed 1 December 2005).

Southern Bluefin Tuna Case - Australia and New Zealand v Japan (Australia and New Zealand $v$ Japan) (Jurisdiction and Admissibility) [2000] available at $<$ http://www.worldbank.org/icsid/bluefintuna/award080400.pdf $>$ (last accessed 1 December 2005). 
The "Camouco" Case (Panama v France) (Prompt Release) [2000] $<\mathrm{http}: / /$ www.itlos.org/> (last accessed 1 December 2005).

The “Chaisiri Reefer 2" Case (Panama v Yemen) (Prompt Release) [2001] $<$ http://www.itlos.org/> (last accessed 1 December 2005).

The "Juno Trader" Case (Saint Vincent and the Grenadines v Guinea-Bissau) (Prompt Release) [2004] <http://www.itlos.org/> (last accessed 1 December 2005).

The "Monte Confurco" Case (Seychelles v France) (Prompt Release) [2000] $<$ http://www.itlos.org/> (last accessed 1 December 2005).

The $M / V$ "Saiga" Case (Saint Vincent and the Grenadines $v$ Guinea) (Prompt Release) [1997]<http://www.itlos.org/> (last accessed 1 December 2005).

The M/V "Saiga" (No 2) Case (Saint Vincent and the Grenadines v Guinea) (Provisional Measures) [1998] <http://www.itlos.org/> (last accessed 1 December 2005).

The MOX Plant Case (Ireland v United Kingdom) (Provisional Measures) [2001] $<$ http://www.itlos.org/> (last accessed 1 December 2005).

The MOX Plant Case (Ireland $v$ United Kingdom) (Further Suspension of Proceedings on Jurisdiction and Merits) [2003] Order No 4, <http://www.pcacpa.org/> (last accessed 1 December 2005).

The "Volga" Case, (Russian Federation v Australia) (Prompt Release) [2002] $<$ http://www.itlos.org/> (last accessed 15 July 2005).

United States - Import Prohibition of Certain Shrimp and Shrimp Products Report of the Appellate Body (12 October 1998) WT/DS58/AB/R; (1999) 38 ILM 118.

United States - Restrictions on Imports of Tuna - Report of the GATT Panel (16 August 1991) DS21/R; (1991) 30 ILM 1598.

United States - Restrictions on Imports of Tuna (US - EU Dispute) - Report of the GATT Panel (20 May 1994) DS29/R; (1994) 33 ILM 842.

WTO Chile - Measures Affecting the Transit and Importation of Swordfish Request for Consultations by the European Communities (26 April 2000) WT/DS193/1.

\section{UNITED NATIONS PUBLICATIONS AND DOCUMENTS}

Annual Report of the International Tribunal for the Law of the Sea 2003, UN Doc SPLOS/109. 
Annual Report of the International Tribunal for the Law of the Sea 2004, UN Doc SPLOS/122.

Report of the Secretary General on Oceans and Law of the Sea, $59^{\text {th }}$ Session, 4 March 2004, UN Doc A/59/62.

Report of the Secretary General on Oceans and Law of the Sea, $59^{\text {th }}$ Session UN Doc A/59/62/Add.1.

Report of the Secretary General on Oceans and Law of the Sea, $60^{\text {th }}$ Session UN Doc A/60/63.

Tenth Meeting of States Parties (22 - 26 May 2000) UN Doc SPLOS/57.

Thirteenth meeting of States Parties (9 - 13 June 2003) UN Doc SPLOS/97.

Fourteenth meeting of States Parties (14 - 18 June 2004) UN Doc SPLOS/117.

Terms of reference, International Tribunal for the Law of the Sea Trust Fund, UN Doc A/RES/55/7.

UN Doc A/CONF.62/WP.9/ADD.1, Off. Rec. V, 122 (President).

United Nations Law of the Sea: Official Text of the UNCLOS (St Martin's Press, London, 1983).

UNGA, Letter dated 10 October 1997 from the Permanent Representative of Portugal to the United Nations addressed to the Secretary - General, (14 October 1997) UN Doc A/52/458.

UNGA, Letter dated 16 October 1998 from the Permanent Representative of Portugal to the United Nations addressed to the Secretary - General, (9 October 1998) UN Doc A/53/524.

UNGA Resolution 59/24 (4 February 2005) A/Res/59/24.

United Nations Secretariat Systematic Survey of Treaties for the Pacific Settlement of International Disputes (Lake Success, New York, 1948).

\section{OFFICIAL STATEMENTS, PRESS RELEASES AND SPEECHES}

ICJ Press Release 2004/ 31 (16 September 2004) <http://www.icjcij.org/icjwww/idocket/iru/iruframe.htm> (last accessed 14 September 2005).

Minister of Foreign Affairs, Alexander Downer and the Attorney-General, Daryl Williams "Changes to International Dispute Resolution" (25 March 2002) Joint Media Release <http://www.foreignminister.gov.au/releases/index.html > (last assessed 7 August 2005). 
Ministry of Foreign Affairs of Japan "Statement by Foreign Minister Masahiko Koumura on the International Tribunal for the Law of the Sea's Order on the Request for Provisional Measures Concerning Japan's Experimental Fishing Program on Southern Bluefin Tuna" (27 August 1999) Press Release, available at $<$ http://www.mofa.go.jp/announce/announce/1999/8/827.html $>$ (last accessed 1 December 2005).

Ministry of Foreign Affairs of Singapore "Joint Press Statement on the Case concerning Land Reclamation by Singapore in and around the Straits of Johor" (26 April 2005) Press Release, available at <http://www.mfa.gov.sg/internet/> (last accessed 1 December 2005).

Ministry of Foreign Affairs of the Republic of Guyana "Brief Summary of Guyana-Suriname Relations", available at $<$ http://www.minfor.gov.gy/relations/suriname.php $>$ (last accessed 10 January 2006).

Nelson, Dolliver Judge, President of ITLOS (Statement to the General Assembly of the United Nations on the Commemoration of the $20^{\text {th }}$ Anniversary of the Opening for Signature of the 1982 United Nations Convention on the Law of the Sea, New York, 9 December 2002) <http://www.itlos.org/> (last accessed 14 September 2005).

Nelson, Dolliver Judge, President of ITLOS (Statement on Agenda Item 25(a) at the Plenary of the Fifty-Seventh Session of the United Nations General Assembly, New York, 10 December 2002) <http://www.itlos.org/> (last accessed 14 September 2005).

Nelson, Dolliver Judge, President of ITLOS (Statement on the Report of the Tribunal at the Fifteenth Meeting of States Parties to the Convention on the Law of the Sea, New York, 16 June 2005) <http://www.itlos.org/> (last accessed 14 September 2005).

New Zealand Ministry of Fisheries "Landmark Decision - New Zealand Tuna Fishing Case" (28 August 1999) Press Release, available at $<$ http://www.fish.govt.nz/current/press/pr990828.htm> (last accessed 1 December 2005).

Permanent Court of Arbitration "Case Concerning Land Reclamation by Singapore In and Around the Straits of Johor" (14 January 2005) Press Release, available at $<$ http://www.pca-cpa.org/> (last accessed 1 December 2005).

Williams, Daryl and Hon Warren Truss "Australia Wins Southern Bluefin Tuna Case" (28 August 1999) Joint Press Release of the Australian Commonwealth Attorney-General and Minister of Agriculture, Fisheries and Forestry, available at $<$ http://www.ag.gov.au/agd/WWW/attorneygeneralHome.nsf/Page/Media_Rel eases_1999_August_Australia_wins_southern_bluefin_tuna_case $>$ (last accessed 1 December 2005). 
Wolfrum, Rüdiger Judge, President of ITLOS (Statement to the Informal Meeting of Legal Advisors of Ministries of Foreign Affairs, New York, 24 October 2005) <http://www.itlos.org/> (last accessed 4 December 2005).

Wolfrum, Rüdiger Judge, President of ITLOS (Statement on Agenda Item 75 (a) at the Plenary of the Sixtieth Session of the United Nations General Assembly, New York, 28 November 2005) <http://www.itlos.org/> (last accessed 14 December 2005).

\section{REPORTS AND OTHER DOCUMENTS FROM INTERNATIONAL ORGANISATIONS AND INSTITUTES}

Asian Development Bank Law and Policy Reform at the Asian Development Bank - Legal Empowerment: Advancing Good Governance and Poverty Reduction (Office of the General Counsel, Asian Development Bank, Manila, 2001).

Cox, Anthony, Matthew Stubbs and Luke Davis Southern Bluefin Tuna and CITES: An Economic Perspective (ABARE Research Report 99, Australian Bureau of Agriculture and Resource Economics, Canberra, 1999).

Decker, Klaus, Caroline Sage and Milena Stefanova "Law or Justice: Building Equitable Legal Institutions" (2005) World Bank Working Paper, Report No 33653.

Food and Agriculture Organization of the United Nations Review of the State of World Marine Fishery Resources (FAO Fisheries Technical Paper 457, FAO, Rome, 2005).

Food and Agriculture Organisation Stopping Illegal, Unreported and Unregulated Fishing (FAO, Rome, 2002).

GESAMP and Advisory Committee on Protection of the Sea A Sea of Troubles (UNEP, GESAMP Reports and Studies 70, London, 2001).

OECD Fish Piracy: Combating Illegal, Unreported and Unregulated Fishing (OECD, Paris, 2004).

Report of the Secretary General of the United Nations Conference on Environment and Development, reprinted in Nicholas A Robinson (ed) Agenda 21 and the UNCED Proceedings (vol 2, Oceana Publications, New York, 1992) 733.

The World Bank World Development Report 2006: Equity and Development (The World Bank and Oxford University Press, New York, 2005).

The World Conservation Union Creating a Sea Change (WWF/IUCN, Gland, Switzerland, 1998). 
UNEP/UNDP Joint Project on Environmental Law and Institutions in Africa Compendium of Judicial Decisions on Matters Related to Environment International Decisions (vol 1, United Nations Environment Programme, Nairobi, 1998).

UNEP "Study on Dispute Avoidance and Dispute Settlement in International Environmental Law" (19 January 1999) UNEP/GC.20/INF/16.

United Nations Environment Programme World Conservation Monitoring Centre A Survey of Global and Regional Marine Environmental Assessments and Related Scientific Activities (UNEP-WCMC, Cambridge, 2003) $<\mathrm{http}$ ://www.unep-wcmc.org/marine/GMA/> (last accessed 19 October 2005).

US Commission on Ocean Policy "The Global Ocean: US Participation in International Policy" in An Ocean Blueprint for the 21st Century (Part VIII, Chapter 29, Final Report, Washington DC, 2004) 442.

\section{TEXTS}

Adede, A O The System for Settlement of Disputes under the United Nations Convention on the Law of the Sea: A Drafting History and a Commentary (Martinus Nijhoff Publishers, Dordrecht, 1987).

Anand, Ram Prakash Studies in International Adjudication (Vikas Publications, Delhi, 1969).

Anand, Ram Prakash International Courts and Contemporary Conflicts (Asia Publishing House, London, 1974).

Anand, Ram Prakash Legal Regime of the Sea-bed and the Developing Countries (Thompson Press, Delhi, 1976).

Anand, Ram Prakash Origin and Development of the Law of the Sea: History of International Law Revisited (Martinus Nijhoff Publishers, The Hague, 1982).

Anand, Ram Prakash International Law and the Developing Countries: Confrontation or Cooperation? (Martinus Nijhoff Publishers, Dordrecht, 1987).

Attard, David Joseph The Exclusive Economic Zone (Oxford University Press, Oxford, 1987).

Birnie, Patricia W and Alan E Boyle International Law And The Environment (Oxford University Press, Oxford, 1992).

Boczek, Boleslaw A International Law: A Dictionary (Scarecrow Press, Lanham (Maryland), 2005).

Borgese, Elisabeth Mann Ocean Governance and the United Nations (Centre for Foreign Policy Studies, Halifax, 1995). 
Borgese, Elisabeth Mann The Oceanic Circle: Governing the Seas as a Global Resource (United Nations University Press, Tokyo, 1998).

Brown, Edward Duncan Sea-Bed Energy and Minerals: The International Legal Regime (vol 1 - The Continental Shelf, Martinus Nijhoff Publishers, Dordrecht, 1992).

Burke, William T, Richard Legatski, William W Woodhead National and International Law Enforcement in the Ocean (University of Washington Press, Seattle, 1975).

Burton, John W Conflict: Resolution and Provention (St Martin's Press, New York, 1990).

Charney, Jonathan I and Lewis M Alexander (eds) International Maritime Boundaries (vol 1, Martinus Nijhoff Publishers, Dordrecht, 1993).

Charney, Jonathan I and Lewis M Alexander (eds) International Maritime Boundaries (vol 2, Martinus Nijhoff Publishers, Dordrecht, 1993).

Charney, Jonathan I and Lewis M Alexander (eds) International Maritime Boundaries (vol 3, Martinus Nijhoff Publishers, Dordrecht, 1998).

Charney, Jonathan I and Robert W Smith (eds) International Maritime Boundaries (vol 4, Martinus Nijhoff Publishers, Dordrecht, 2002).

Chayes, Abram and Antonia Handler Chayes The New Sovereignty: Compliance with International Regulatory Agreements (Harvard University Press, Cambridge (Mass), 1995).

Churchill, Robin and Geir Ulfstein Marine Management in Disputed Areas: The Case of the Barents Sea (Routledge, London, 1992).

Churchill, Robin Rolf and Alan Vaughan Lowe The Law of the Sea (Manchester University Press, New York, 1999).

Collier, John and Vaughan Lowe The Settlement of Disputes in International Law: Institutions and Procedures (Oxford University Press, Oxford, 1999).

Colson, David A and Robert W Smith (eds) International Maritime Boundaries (vol 5, Martinus Nijhoff Publishers, Leiden, 2005).

Commission on Global Governance Our Global Neighbourhood: The Report of the Commission on Global Governance (Oxford University Press, Oxford, 1995).

Constanza, Robert and Francisco Andrade (eds) Ecological Economics and Sustainable Governance of the Oceans (Fundação Luso-Americana para $\mathrm{o}$ Desenvolvimento, IMAR-Instituto do Mar, Lisbon, 1998). 
Corcoran, Emily A Survey of Global and Regional Marine Environmental Assessments and Related Scientific Activities (United Nations Environment Programme - World Conservation Monitoring Centre, Cambridge, 2003).

Ehrlich, Paul and Anne Extinction: The Causes and Consequences of the Disappearances of Species (Random House, New York, 1981).

Dahmani, M The Fisheries Regime of the Exclusive Economic Zone (Martinus Nijhoff Publishers, Dordrecht, 1987).

Eiriksson, Gudmundur International Tribunal for the Law of the Sea (Kluwer Law International, The Hague, 2000).

Ellis, Richard The Empty Ocean: Plundering the World's Marine Life (Island Press, Washington DC, 2003).

Extavour, Winston Conrad The Exclusive Economic Zone: A Study of the Evolution and Progressive Dvelopment of the International Law of the Sea (Sijthoff, Leiden, 1979).

Falk, Richard On Humane Governance: Toward a New Global Politics (Pennsylvania State University Press, Pennsylvania, 1995).

Freestone, David and Ellen Hey (eds) The Precautionary Principle and International Law: The Challenge of Implementation (Kluwer Law International, Boston, 1995).

Gold, Edgar and Christopher Petrie "International Maritime Organizations and Institutions" in Edgar Gold (ed) Maritime Affairs: A World Handbook (2 ed, Longman Group UK Limited, Harlow, Essex, 1991).

Goldsmith, Jack L and Eric A Posner The Limits of International Law (Oxford University Press, Oxford, 2005).

Gorshkov, S G The Sea Power of the State (Naval Institute Press, Annapolis (Maryland), 1976).

Grotius, Hugo The Freedom of the Seas or The Right which Belongs to the Dutch to Take Part in the East Indian Trade (Translated with a Revision of the Latin Text of 1633 by Ralph van Deman Magoffin, Edited with an Introductory Note by James Brown Scott, Oxford University Press, New York, 1916, Reprint, Lawbook Exchange, Clark (New Jersey), 2001).

Hardin, Garrett and John Baden (eds) Managing the Commons (W H Freeman, San Francisco, 1977).

Hewson, Martin and Timothy J Sinclair (eds) Approaches to Global Governance Theory (State University of New York Press, Albany, 1999). 
Hjertonsson, Karin The New Law of the Sea: Influence of the Latin American States on Recent Developments of the Law of the Sea (A W Sijthoff, Leiden, 1973).

Hudson, Manley O International Tribunals: Past and Future (Carnegie Endowment for International Peace and Brookings Institution, Washington DC, 1944).

Jagota, S P Maritime Boundary (Martinus Nijhoff Publishers, Dordrecht, 1985).

Jacques, Peter and Zachary A Smith Ocean Politics and Policy: A Reference Handbook (ABC-CLIO Inc, Santa Barbara, California, 2003).

Jenks, Clarence Wilfred The Prospects of International Adjudication (Steven, London, 1964).

Johnston, Douglas M The Theory and History of Ocean Boundary-Making (McGill-Queen's University Press, Kingston, 1988).

Juda, Lawrence International Law and Ocean Use Management: The Evolution of Ocean Governance (Routledge, London, 1996).

Kaikobad, Kaiyan Homi The International Court of Justice and Judicial Review: A Study of the Court's Powers with Respect to Judgments of the ILO and UN Administrative Tribunals (Kluwer Law International, The Hague, 2000).

Kalo, Joseph J and others Coastal and Ocean Law: Cases and Materials (3 ed, West Group, St Paul, Minnesota, 1999).

Kaye, Stuart M International Fisheries Management (Kluwer Law International, The Hague, 2001).

Keith, Kenneth James The Extent of the Advisory Jurisdiction of the International Court of Justice (A W Sijthoff, Leiden, 1971).

Kimball, Lee A International Ocean Governance: Using International Law and Organizations to Manage Marine Resources Sustainably (IUCN, Gland, 2001).

Klein, Natalie Dispute Settlement in the UN Convention on the Law of the Sea (Cambridge University Press, Cambridge, 2005).

Kolb, Robert Case Law on Equitable Maritime Delimitation (Martinus Nijhoff Publishers, The Hague, 2003).

Kurien, John Property Rights, Management and Governance: Crafting an Institutional Framework for Global Marine Fisheries (Centre for Development Studies and South Indian Federation of Fishermen Societies, Thiruvananthapuram, 1998). 
Kwiatkowska, Barbara The 200 Mile EEZ in the New Law of the Sea (Dordrecht, Martinus Nijhoff Publishers, 1989).

Kwaitkowska, Barbara Decisions of the World Court Relevant to the UN Convention on the Law of the Sea - A Reference Guide (Kluwer Law International, The Hague, 2002).

Lessig, Lawrence Code and Other Laws of Cyberspace (Basic Books, New York, 1999).

Mahan, Alfred Thayer The Influence of Sea Power Upon History 1660-1783 (First published in 1890 by Little, Brown \& Co, Boston, Massachusetts; reprint, Methuen \& Co Ltd, London, 1965).

Marx, Wesley The Oceans, Our Last Resource (Sierra Club Books, San Francisco, 1981).

McDorman, Ted, L Kenneth P Beauchamp, Douglas M Johnston Maritime Boundary Delimitation: An Annotated Bibliography (LexingtonBooks, Lexington (Mass), 1983).

McDorman, Ted L and others International Ocean Law: Materials and Commentaries (Carolina Academic Press, Durham, (North Carolina) 2005).

Merrills, J G International Dispute Settlement (3 ed, Cambridge University Press, New York, 1998).

O'Connell, Mary Ellen (ed) International Dispute Settlement (Dartmouth Publishing Company, Hants, England, 2003).

Ostrom, Elinor Governing the Commons: The Evolution of Institutions for Collective Action (Cambridge University Press, New York, 1990).

Paquet, Gilles and Kevin Wilkins Ocean Governance: An Inquiry into Stakeholding (Centre on Governance, University of Ottawa, Ottawa, 2002).

Pratap, Dharma The Advisory Jurisdiction of the International Court (Oxford University Press, London, 1972).

Rajagopal, Balakrisnan International Law From Below: Development, Social Movements and Third World Resistance (Cambridge University Press, Cambridge, 2003).

Rayfuse, Rosemary Gail Non-Flag State Enforcement in the High Seas Fisheries (Maritinus Nijhoff Publishers, Leiden, 2004).

Reinicke, Wolfgang $\mathrm{H}$ and others Critical Choices: The United Nations, Networks, and the Future of Global Governance (International Development Research Centre, Ottawa, 2000). 
Rembe, Nasila S Africa and the International Law of the Sea: A Study of the Contribution of the African States to the Third United Nations Conference on The Law of the Sea (Sijthoff \& Noordhoff, Alphen aan den Rijn (The Netherlands), 1980).

Rhodes, R A W Understanding Governance: Policy Networks, Governance, Reflexivity and Accountability (Open University Press, Buckingham, 1997).

Romano, Cesare P R The Peaceful Settlement of International Environmental Disputes - A Pragmatic Approach (Kluwer Law International, London, 2000).

Rosenne, Shabtai The Law and Practice of the International Court (vol 2, A W Sijthoff, Leyden, 1965).

Rosenne, Shabtai and Louis B Sohn (eds) United Nations Convention on the Law of the Sea 1982: A Commentary (vol 5, Martinus Nijhoff Publishers, Dordrecht, 1989).

Rosenne, Shabtai The World Court: What it is and How it Works (5 ed, Martinus Nijhoff Publishers, Dordrecht, 1995).

Rosenne, Shabtai Provisional Measures in International Law: The International Court of Justice and the International Tribunal for the Law of the Sea (Oxford University Press, Oxford, 2005).

Schelling, Thomas C The Strategy of Conflict (Harvard University Press, Cambridge (Mass), 1960).

Sebenius, James K Negotiating the Law of the Sea (Harvard University Press, Cambridge (Mass), 1984).

Selden, John Of the Dominion, or, Ownership of the Sea. Two Books: In the First, is Shew'd that the Sea, by the Law of Nature, or Nations, is Not Common to All Men but Capable of Private Dominion or Proprietie as well as the Land in the Second, is Proved That the Dominion of the British Sea, or That Which Incompasseth the Isle of Great Britain, is, and Ever Hath Been, a Part or Appendant of the Empire of that Island. Written at First in Latin and Entitled Mare Clausum, Seu, De Dominio Maris (Translated into English and set forth with some additional evidences and discourses by Marchmont Nedham, Lawbook Exchange, Clark (New Jersey), 2003).

Shany, Yuval The Competing Jurisdictions of International Courts and Tribunals (Oxford University Press, Oxford, 2003).

Shelton, Dinah and Alexandre Kiss Judicial Handbook on Environmental Law (United Nations Environment Programme, Nairobi, 2005).

Simon, Anne W Neptune's Revenge: The Ocean of Tomorrow (Franklin Watts, New York, 1984). 
Simpson, J L and Hazel Fox International Arbitration: Law and Practice (Stevens, London, 1959).

Sinclair, Ian The Vienna Convention on the Law of Treaties (2 ed, Manchester University Press, Manchester, 1984).

Singh, Gurdip United Nations Convention on the Law of the Sea Dispute Settlement Mechanisms (Academic Publications, New Delhi, 1985).

Smith, Robert W Exclusive Economic Zone Claims: An Analysis and Primary Documents (Martinus Nijhhoff Publishers, Dordrecht, 1986).

Steinberg, Philip E The Social Construction of the Ocean (Cambridge University Press, Cambridge, 2001).

Stern, Paul C and Daniel Druckman (eds) International Conflict Resolution After the Cold War (National Academy Press, Washington DC, 2000).

Trouwborst, Arie Evolution and Status of the Precautionary Principle in International Law (Kluwer Law International, The Hague, 2002).

Vallega, Adalberto Sea Management: A Theoretical Approach (Elsevier Applied Science, London, 1992).

Vallega, Adalberto Sustainable Ocean Governance: A Geographical Perspective (Routledge, London, 2001).

Victor, David G Kal Raustiala and Eugene B Skolnikoff (eds) The Implementation and Effectiveness of International Environmental Commitments: Theory and Practice (The MIT Press, Cambridge (Mass), 1998).

Victor, John Robert and Clive Schofield The Maritime Political Boundaries of the World (Martinus Nijhoff Publishers, Leiden, 2005).

Vicuña, Francisco Orrego The Changing International Law of High Seas Fisheries (Cambridge University Press, Cambridge, 1999).

Vicuña, Francisco Orrego International Dispute Settlement in an Evolving Global Society: Constitutionalization, Accessibility, Privatization (Cambridge University Press, Cambridge, 2004).

Vilkka, Leena The Intrinsic Value of Nature (Rodopi, Amsterdam, 1997).

Viscusi, W Kip (ed) Regulation Through Litigation (AEI-Brookings Joint Center for Regulatory Studies, Washington DC, 2002).

Walz, Jonathan A and Douglas Campbell III in Larson, David L (ed) Major Issues of the Law of the Sea (University of New Hampshire, (Durham) New Hampshire, 1976). 
Wang, James C F Handbook on Ocean Politics and Law (Greenwood Press, New York, 1992).

Watt, Donald Cameron The Future Governance of the Seas: An Inaugural Lecture for the Inauguration of the M Sc Course in Sea Use: Law, Economics and Policy - Making (The London School of Economics and Political Science, London, 10 October 1979).

Wettestad, Jorgen Designing Effective Environmental Regimes: The Key Conditions (Edward Elgar Publishing Limited, Cheltenham, 1995).

Yarn, Douglas H "Conflict" in Douglas H Yarn (ed) Dictionary of Conflict Resolution (Jossey-Bass, San Francisco, 1999).

Young, Oran Resource Management at the International Level: The Case of the North Pacific (Frances Printer, London, 1977).

Young, Oran International Cooperation: Building Regimes for Natural Resources and the Environment (Cornell University Press, Ithaca, 1989).

Young, Oran R International Governance: Protecting the Environment in a Stateless Society (Cornell University Press, Ithaca, 1994).

Zacher, Mark W and Brent A Sutton Governing Global Networks: International Regimes for Transportation and Communications (Cambridge University Press, Cambridge, 1996).

\section{BOOK CHAPTERS AND ARTICLES}

Abbott, Kenneth W and Duncan Snidal "Hard and Soft Law in International Governance" (2000) 54 (3) Intl Org 421.

Abraham, Kenneth A "The Insurance Effects of regulation by Litigation" in W Kip Viscusi (ed) Regulation Through Litigation (AEI-Brookings Joint Center for Regulatory Studies, Washington DC, 2002) 212.

Abrahams, Darren "International Tribunal for the Law of the Sea - The Mox Plant Case (Ireland v United Kingdom), Request for Provisional Measures" (2002) 14 (3) JEL 398.

Adede, A O "Settlement of Disputes Arising under the Law of the Sea Convention" (1975) 69 AJIL 798.

Adede, A O "Prolegomena to the Disputes Settlement Part of the Law of the Sea Convention" (1977) 10 (2) N Y U J Intl L \& Pol 253.

Adede, A O "Law of the Sea: The Scope of the Third-Party Compulsory Procedures for Settlement of Disputes" (1977) 71 AJIL 305. 
Adede, A O 'Law of the Sea - Developing Countries' Contribution to the Development of Institutional Arrangements for the International Sea-Bed Authority" (1977) 4 Brook J Intl L 1.

Adede, A O "Law of the Sea - The Integration of the System of the Settlement of Disputes Under the Draft Convention as a Whole" (1978) 72 AJIL 84.

Adede, A O "Towards the formulation of the Rule of Delimitation of Sea Boundaries Between States with Adjacent or Opposite Coasts" (1979) 19 (2) Va J Intl L 207.

Adede, A O "Streamlining the System for Settlement of Disputes under the Law of the Sea Convention" (1980) 1 Pace L Rev 15.

Adede, A O "The Basic Structure of the Disputes Settlement Part of the Law of the Sea Convention" (1982) 11 (1/2) ODIL 125.

Agnew, D J "The Illegal and Unregulated Fishery for Toothfish in the Southern Ocean, and the CCAMLR Catch Documentation Scheme" (2000) 24 Marine Policy 361.

Akl, Joseph "The Legal Status, Privileges and Immunities of the International Tribunal for the Law of the Sea" (1998) 2 Max Planck Yrbk UN L Law 341.

Akl, Joseph "Question of Time - Limits in Urgent Proceedings Before the Tribunal" in M H Nordquist and J N Moore (eds) Current Marine Environmental Issues and the International Tribunal for the Law of the Sea (Kluwer Law International, The Hague, 2001) 75.

Allison, Edward H "Big Laws, Small Catches: Global Ocean Governance and the Fisheries Crisis” (2001) 13 J Int Dev 933.

Allott, Phillip "Mare Nostrum: A New International Law" in Jon M Van Dyke, Durwood Zaelke and Grant Hewison (eds) Freedom for the Seas in the 21st Century: Ocean Governance and Environmental Harmony (Island Press, Washington DC, 1993) 49.

Allott, Philip "Power Sharing in the Law of the Sea" (1983) 77 AJIL 1.

Amerasinghe, Hamilton S "The Third World and the Seabed" in Elisabeth Mann Borgese (ed) Pacem in Maribus (Dodd, Mead \& Company, New York, 1972) 237.

Anand, Ram Prakash "Role of International Adjudication" in Leo Gross (ed) The Future of the International Court of Justice (vol 1, Oceana Publications, Dobbs Ferry (New York), 1976) 1.

Anand, Ram Prakash "Freedom of the Seas: Past, Present and Future" in Rafael Gutiérrez Girardot and others (eds) New Directions In International Law: Essays in Honour of Wolfgang Abendroth (Campus Verlag, New York, 1982) 215. 
Anderson, David H "Investigation, Detention and Release of Foreign Vessels under the UN Convention on the Law of the Sea of 1982 and Other International Instruments" (1996) 11 (2) IJMCL 165.

Anderson, David "The International Tribunal for the Law of the Sea" in Malcolm Evans (ed) Remedies in International Law: The Institutional Dilemma (Hart Publishing, Oxford, 1998) 71.

Anderson, David "Negotiation and Dispute Settlement" in Malcolm Evans (ed) Remedies in International Law: The Institutional Dilemma (Hart Publishing, Oxford, 1998) 111.

Anderson, David H "Deliberations, Judgments, and Separate Opinions in the Practise of the International Tribunal for the Law of the Sea" in M H Nordquist and J N Moore (eds) Current Marine Environmental Issues and the International Tribunal for the Law of the Sea (Kluwer Law International, The Hague, 2001) 63.

Anderson, David H "Trust Funds in International Litigation" in Nisuke Endo and others (eds) Liber Amicorum Judge Shigeru Oda (vol 2, Kluwer Law International, The Hague, 2002) 793.

Anderson, David H "The Role of ITLOS as a Means of Dispute Settlement under UNCLOS" in Andree Kirchner (ed) International Marine Environmental Law: Institutions, Implementation And Innovations (Kluwer Law International, The Hague, 2003) 19.

Anderson, David "The Regulation of Fishing and Related Activities in Exclusive Economic Zones" in Erik Franckx and Philippe Gautier (eds) La Zone Économique Exclusive Et La Convention Des Nations Unies Sur Le Droit De La Mer, 1982-2000: Un Premier Bilan De La Pratique Des Etats = The Exclusive Economic Zone And The United Nations Convention On The Law Of The Sea, 1982-2000: A Preliminary Assessment Of State Practice (Bruylant, Brussels, 2003) 31 .

Anderson, David H "The Effective Administration of International Justice: Early Practice of the International Tribunal for the Law of the Sea" in Jochen Abr Frowein and others (eds) Verhandeln Für Den Frieden = Negotiating For Peace: Liber Amicorum Tono Eitel (Springer, Berlin, 2003) 529.

Anderson, H Edwin III "The Nationality of Ships and Flags of Convenience: Economics, Politics, and Alternatives" (1996) 21 Tul Mar L J 139.

Antunes, Paula and Rui Santos "Integrated Environmental Management of the Oceans" (1999) 31 Ecological Economics 215.

Bialek, Dean "Australia \& New Zealand v Japan: Southern Bluefin Tuna Case" (2000) 1 Melb J Intl L 153. 
Baird, Rachel "Illegal, Unreported and Unregulated Fishing: An Analysis of the Legal, Economic and Historical Factors Relevant to its Development and Persistence" (2004) 5 Melb J Intl L 299.

Baird, Rachel "Testing the Waters: Fine Tuning the Provisions of the Fisheries Management Act 1991 (Cth) Applicable to Foreign Fishing Boats" (2004) 32 UWAL Rev 63.

Baldock, Julia "Determining the Fate of Southern Bluefin Tuna - International Tribunal for the Law of the Sea (1999) New Zealand v Japan; Australia v Japan" (2000) EPLJ 157.

Bardin, Anne "Coastal State Jurisdiction over Foreign Vessels" (2002) 14 Pace Intl L Rev 27.

Bello, Emmanuel G "International Equity and the Law of the Sea: New Perspectives for Developing Countries" (1980) 13 Verfassung und Recht in Übersee, 201.

Bergin, Anthony and Marcus Haward "Southern Bluefin Tuna Fishery: Recent Developments in International Management" (1994) 18 Marine Policy 263.

Bernhardt, J Peter A "Compulsory Dispute Settlement in the Law of the Sea Negotiations: A Reassessment” (1978) 19 Va J Intl L 69.

Bialek, Dean "Australia \& New Zealand v Japan: Southern Bluefin Tuna Case" (2000) 1 Melb J Intl L 153.

Bilder, Richard "The Settlement of Disputes in the Field of International Law of the Environment" (1975) 44 Recueil des Cours 139.

Bilder, Richard B “An Overview of International Dispute Settlement” (1986) 1 Emory J Intl Dispute Res 1.

Bilder, Richard B "International Dispute Settlement and the Role of Adjudication” (1987) 1 Emory J Intl Dispute Res 131.

Bilder, Richard B "International Third Party Dispute Settlement" (1989) 17 Denv J Intl L \& Poly 471.

Bilder, Richard "Commentary" in Thomas A Mensah (ed) Ocean Governance: Strategies and Approaches for the $21^{\text {st }}$ Century (The Law of the Sea Institute, University of Hawaii, Honolulu, 1994) 256.

Bilder, Richard B "Adjudication: International Arbitral Tribunals and Courts" in I William Zartman and J Lewis Rasmussen (eds) Peacemaking in International Conflict: Methods \& Techniques (United States Institute of Peace Press, Washington DC, 1997) 115. 
Birnie, P W "Legal Techniques of Settling Disputes: The 'Soft Settlement' Approach" in William E Butler (ed) Perestroika and International Law (Martinus Nijhoff Publishers, Dordrecht, 1990) 177.

Birnie, Patricia "The Challenges of Applying UNCLOS in a Post UNCED Context" in Joseph J Norton, Mads Andenas and Mary Footer (eds) The Changing World of International Law in the Twenty-First Century: A Tribute to the Late Kenneth R Simmonds (Kluwer Law International, The Hague, 1997) 3.

Bloomfield, Lincoln P "Enforcing Rules in the International Community: Governing the Ungovernable?" in Issues in Global Governance: Papers Written for the Commission on Global Governance (Kluwer Law International, London, 1995) 219.

Bodansky, Daniel "Deconstructing the Precautionary Principle" in David D Caron and Harry N Scheiber (eds) Bringing New Law to Ocean Waters (Martinus Nijhoff Publishers, Leiden, 2004) 381.

Boesch, Donald F "The Role of Science in Ocean Governance" (1999) 31 Ecological Economics 189.

Borgese, Elisabeth Mann "What Can Developing Countries Gain from the United Nations Convention on the Law of the Sea?" (1985) 6 Trade \& Dev 123.

Borgese, Elisabeth Mann "The Process of Creating an Ocean Regime to Protect the Ocean's Resources" in Jon M Van Dyke, Durwood Zaelke and Grant Hewison (eds) Freedom for the Seas in the 21st Century: Ocean Governance and Environmental Harmony (Island Press, Washington DC, 1993) 23.

Borgese, Elisabeth Mann "Pacem in Maribus XIX - Background Paper" in Peter Bautista Payoyo (ed) Ocean Governance: Sustainable Development of the Seas (United Nations University Press, Tokyo, 1994) 350.

Borgese, Elisabeth Mann "Global Civil Society: Lessons from Ocean Governance" (1999) 31 Futures 983.

Borgese, Elisabeth Mann "The Economics of the Common Heritage" (2000) Ocean \& Coastal Management 763.

Boutillon, Sonia "The Precautionary Principle: Development of an International Standard” (2002) 23 Mich J Intl L 429.

Boyle, Alan E "Saving the World? Implementation and Enforcement of International Environmental Law Through International Institutions" (1991) 3 J Envtl L 229. 
Boyle, Alan E "The International Tribunal for the Law of the Sea and the Settlement of Disputes" in Joseph J Norton, Mads Andenas and Mary Footer (eds) The Changing World of International Law in the Twenty-First Century: A Tribute to the Late Kenneth $R$ Simmonds (Kluwer Law International, The Hague, 1997) 99.

Boyle, Alan E "UNCLOS, the Marine Environment and the Settlement of Disputes" in Hendrik Ringbom (ed) Competing Norms in the Law of Marine Environmental Protection - Focus on Ship Safety and Pollution Prevention (Kluwer Law International, London, 1997) 241.

Boyle, Alan E "Dispute Settlement and the Law of the Sea Convention: Problems of Fragmentation and Jurisdiction" (1997) 46 ICLQ 37.

Boyle, Alan E “The Southern Bluefin Tuna Arbitration” (2001) 50 ICLQ 447.

Boyle, Alan "Problems of Compulsory Jurisdiction and the Settlement of Disputes Relating to Straddling Fish Stocks" in Olav Schram Stokke (ed) Governing High Seas Fisheries: The Interplay of Regional Regimes (Oxford University Press, Oxford, 2001) 91.

Boyle, Alan "Some Problems of Compulsory Jurisdiction before Specialised Tribunals: The Law of the Sea" in Patrick Capps, Malcolm Evans and Strato Konstadinidis (eds) Asserting Jurisdiction: International and European Legal Perspectives (Hart Publishing, Portland (Oregon), 2003) 243.

Boyle, Alan "Further Development of the Law of the Sea Convention: Mechanisms for Change" (2005) 54 (3) ICLQ 563.

Bracegirdle, Allan "New Zealand v Japan, Australia v Japan (Southern Bluefin Tuna Cases) (International Tribunal for the Law of the Sea, 27 August 1999)" [1999] NZLJ 375.

Brierly, James Leslie "The Shortcomings of International Law" (1924) 5 BYBIL 4.

Brierly, James Leslie "The Judicial Settlement of International Disputes" in Hersch Lauterpacht and $\mathrm{C} \mathrm{H} \mathrm{M} \mathrm{Waldock} \mathrm{(eds)} \mathrm{The} \mathrm{Basis} \mathrm{of} \mathrm{Obligation} \mathrm{in}$ International Law and Other Papers by the Late James Leslie Brierly (Oxford University Press, Oxford, 1958) 93.

Brown, Chester "Provisional Measures Before the ITLOS: The MOX Plant Case" (2002) 17 (2) IJMCL 267.

Brown, Chester "'Reasonableness' in the Law of the Sea: The Prompt Release of the Volga" (2003) 16 LJIL 621.

Brown, Edward Duncan "Dispute Settlement and the Law of the Sea: The UN Convention Regime” (1997) 21 (1) Marine Policy 17. 
Brown, Edward Duncan "The M/V 'Saiga' Case on Prompt Release of Detained Vessels: The First Judgment of the International Tribunal for the Law of the Sea" (1998) 22 (4-5) Marine Policy 307.

Brownlie, Ian "Why do States Take Disputes to the International Court?" in Nisuke Endo and others (eds) Liber Amicorum Judge Shigeru Oda (vol 2, Kluwer Law International, The Hague, 2002) 829.

Burgt, Nienke van der "The 1982 United Nations Convention on the Law of the Sea and its Dispute Settlement Procedure" (2005) 6 (1) Griffin's View 18.

Burke, William T "Unregulated High Seas Fishing and Ocean Governance" in Jon M Van Dyke, Durwood Zaelke and Grant Hewison (eds) Freedom for the Seas in the 21st Century: Ocean Governance and Environmental Harmony (Island Press, Washington DC, 1993) 235.

Buzan, Barry "A Sea of Troubles? Sources of Disputes in the New Ocean Regime” (International Institute of Strategic Studies, London, 1978).

Caminos, Hugo "The Jurisdiction of the International Tribunal for the Law of the Sea: An Overview" in Myron H Nordquist and John Norton Moore (eds) Oceans Policy: New Institutions, Challenges and Opportunities (Kluwer Law International, The Hague, 1999) 93.

Caminos, Hugo "The Establishment of Specialized Courts" in Myron $\mathrm{H}$ Nordquist and John Norton Moore (eds) Current Marine Environmental Issues and the International Tribunal for the Law of the Sea (Kluwer Law International, The Hague, 2001) 33.

Caminos, Hugo "The Creation of Specialised Courts: The Case of the International Tribunal for the Law of the Sea" in Nisuke Endo and others (eds) Liber Amicorum Judge Shigeru Oda (vol 1, Kluwer Law International, The Hague, 2002) 569.

Carlarne, Cinnamon Pinon "Saving The Whales In The New Millennium: International Institutions, Recent Developments And The Future Of International Whaling Policies" (2005) 24 Va Envtl LJ 1, 46.

Carley, Michael and Ian Christie "The World's Commons: The Challenge of Governance" in Governance for a Sustainable Future: Reports of the Commissions of World Humanity Action Trust (World Humanity Action Trust, London, 2000).

Carnegie, A R “The Law of the Sea Tribunal” (1979) 28 ICLQ 669.

Carnegie, A R "The Challenge of Environmental Law to the Montego Bay Convention" (1995) 25/6 Envtl Poly \& L 302. 
Carr, James and Matthew Gianni "High Seas Fisheries, Large - Scale Drift Nets, and the Law of the Sea" in Jon M Van Dyke, Durwood Zaelke and Grant Hewison (eds) Freedom for the Seas in the 21st Century: Ocean Governance and Environmental Harmony (Island Press, Washington DC, 1993) 272.

Charlesworth, Hilary "The Unbearable Lightness of Customary International Law” (1998) 92 Am Socy Intl L Proc 44.

Charney, Jonathan I "Progress in International Maritime Boundary Delimitation Law" (1994) 88 AJIL 227, 227.

Charney, Jonathan I "The Implications of Expanding International Dispute Settlement Systems: The 1982 Convention on the Law of the Sea" (1996) 90 AJIL 69.

Charney, Jonathan I "Is International Law Threatened by Multiple International Tribunals?" (1998) 271 Recueil des Cours 115.

Charney, Jonathan I "The Impact on the International Legal System of the Growth of International Courts and Tribunals" (1999) 31 NYUJ Intl L \& Pol 697.

Chigara, Ben "The International Tribunal for the Law of the Sea and Customary International Law" (2000) 22 Loy L A Intl \& Comp L Rev 433.

Chinkin, Christine and Romana Sadurska "The Anatomy of International Dispute Resolution” (1991) 7 Ohio St J Disp Resol 39.

Chinkin, Christin "Dispute Resolution in the Law of the Sea: Regional Problems and Prospects" in J Crawford and D R Rothwell (eds) The Law of the Sea in the Asian Pacific Region (Kluwer Academic Publishers, The Hague, 1995) 237.

Chitty, Gritakumar E "A Brief History of the Post Conference Development of the Tribunal as an International Judicial Body" in Myron H Nordquist and John Norton Moore (eds) Current Marine Environmental Issues and the International Tribunal for the Law of the Sea (Kluwer Law International, The Hague, 2001) 41.

Churchill, Robin R "Dispute Settlement in the Law of the Sea - the Context of the International Tribunal for the Law of the Sea and Alternatives to it" in Malcolm Evans (ed) Remedies in International Law: The Institutional Dilemma (Hart Publishing, Oxford, 1998) 85.

Churchill, Robin R "Levels of Implementation of the Law of the Sea Convention: An Overview" in Davor Vidas and Willy Østreng (eds) Order for the Oceans at the Turn of the Century (Kluwer Law International, The Hague, 1999) 317. 
Churchill, Robin R "International Tribunal for the Law of the Sea: The Southern Bluefin Tuna Cases (New Zealand v Japan; Australia v Japan): Order for Provisional Measures of 27 August 1999” (2000) 49 ICLQ 979.

Churchill, Robin and Vaughan Lowe "The International Tribunal for the Law of the Sea: Survey for 2002" (2003) 18 (4) IJMCL 447.

Churchill, Robin "The International Tribunal for the Law of the Sea: Survey for 2003” (2004) 19 (4) IJMCL 369.

Churchill, Robin and Joanne Scott "The MOX Plant Litigation: The First Halflife" (2004) 53 ICLQ 643.

Churchill, Robin R "The Role of the International Court of Justice in Maritime Boundary Delimitation" in Alex G Oude Elferink and Donald R Rothwell Oceans Management in the 21st Century: Institutional Frameworks and Responses (Martinus Nijhoff Publishers, Leiden, 2004) 125.

Clingan, Thomas A Jr "Dispute Settlement" in The Law of the Sea: Ocean Law and Policy (Austin \& Winfield Publishers, Lanham (Maryland), 1994) 517.

Coffen-Smout, Scott and Glen J Herbert "Submarine Cables: A Challenge for Ocean Development" (2000) 24 Marine Policy 441.

Colson, David A and Peggy Hoyle "Satisfying the Procedural Prerequisites to the Compulsory Dispute Settlement Mechanisms of the 1982 Law of the Sea Convention: Did the Southern Bluefin Tuna Tribunal Get it Right?" (2003) 34 ODIL 59.

Committee on International Conflict Resolution, National Research Council "Conflict Resolution in a Changing World" in Paul C Stern and Daniel Druckman (eds) International Conflict Resolution After the Cold War (National Academy Press, Washington DC, 2000) 1.

Contanza, Robert and others "Principles for Sustainable Governance of the Oceans" (1998) 281 Science 198.

Constanza, Robert and others "Ecological Economics and Sustainable Governance of the Oceans" (1999) 31 Ecological Economics 171.

Constanza, Robert "The Ecological, Economic, and Social Importance of the Oceans" (1999) 31 Ecological Economics 199.

Coquia, Jorge R "Settlement of Disputes in the UN Convention on the Law of the Sea" (1985) 25 (2) IJIL 171.

Corell, Hans "Future Role of the United Nations in Ocean and Law of the Sea" in Myron H Nordquist and John Norton Moore (eds) Oceans Policy: New Institutions, Challenges and Opportunities (Kluwer Law International, The Hague, 1999) 15. 
Cot, Jean-Pierre “Appearing 'For' or 'On Behalf of' a State: The Role of Private Counsel Before International Tribunals" in Nisuke Endo and others (eds) Liber Amicorum Judge Shigeru Oda (vol 2, Kluwer Law International, The Hague, 2002) 835 .

Couper, Alastair D and H D Smith "The North Sea: Bases for Management and Planning in a Multi-State Sea Region" in Douglas M Johnston and Norman G Letalik (eds) in The Law of the Sea and Ocean Industry: New Opportunities and Restraints (Law of the Sea Institute, University of Hawaii, Honolulu, 1983) 63.

Craik, A Neil "Recalcitrant Reality and Chosen Ideals: The Public Function of Dispute Settlement in International Environmental Law" (1998) 10 Geo Intl Envtl L Rev 551.

Davey, William “Dispute Settlement in GATT” (1987) 11 Fordham Intl L J 51.

Davis, Bruce "Contemporary Ocean and Coastal Management Issues in Australia and New Zealand: An Overview" (1996) 33 Ocean \& Coastal Management 5.

Davis, W Jackson "The Need for a New Global Ocean Governance System" in Jon M Van Dyke, Durwood Zaelke and Grant Hewison (eds) Freedom for the Seas in the 21st Century: Ocean Governance and Environmental Harmony (Island Press, Washington DC, 1993) 147.

De Senarclens, Pierre "Governance and the Crisis in the International Mechanisms of Regulation" (1998) 155 International Social Science Journal 91.

Dean, Arthur H "The Geneva Conference on the Law of the Sea: What was Accomplished” (1958) 52 AJIL 607.

Devine, D J “Compulsory Dispute Settlement in UNCLOS Undermined?" (2000) 25 SAYIL 97.

Devine, D J "Prompt Release of Vessel and Master" (2000) 25 SAYIL 227.

Devine, D J "Relevant Factors in Establishing a Reasonable Bond for Prompt Release of a Vessel under Article 292 (1) of the United Nations Convention on the Law of the Sea 1982” (2002) 27 SAYIL 140.

Devine, D J "Provisional Measures Ordered by the International Tribunal for the Law of the Sea in the Area of Pollution" (2003) 28 SAYIL 263.

Devine, D J "Short - Circuiting the Right to Prompt Release" (2003) 28 SAYIL 300.

Dietz, Thomas and others "The Drama of the Commons" in Elinor Ostrom and others (eds) The Drama of the Commons (National Academy Press, Washington DC, 2002) 3. 
Dietz, Thomas, Elinor Ostrom and Paul C Stern "The Struggle to Govern the Commons" (2003) 302 Science 1907.

Djalal, Hasjim "The Developing Countries and the Law of the Sea Conference" (1980) IX/1 The Indonesian Quarterly 59.

Hasjim Djalal "A Southeast Asian Perspective" in Giulio Pontecorvo (ed) The New Order of the Oceans: The Advent of a Managed Environment (Columbia University Press, New York, 1986) 199.

Donovan, Thomas W "Suriname-Guyana Maritime and Territorial Disputes: A Legal and Historical Analysis” (2003) Fla St J Transnatl L \& Poly 41.

Donovan, Thomas W "Challenges to the Territorial Integrity of Guyana: A Legal Analysis" (2004) 32 Ga J Intl \& Comp L 661.

Dunworth, Teresa "Bluefin Tuna" [1999] NZLJ 395.

Dupont, Alan "Maritime Environmental Security" in David Wilson and Dick Sherwood (eds) Oceans Governance and Maritime Strategy (Allen \& Unwin, St Leonards (NSW), 2000) 129.

Dupuy, Pierre-Marie "Danger of Fragmentation or Unification of the International Legal System and the International Court of Justice" (1999) 31 N Y U J Intl L \& Pol 791.

Dzidzornu, David M “Coastal State Obligations and Powers Respecting EEZ Environmental Protection Under Part XII of the UNCLOS: A Descriptive Analysis" (1997) 8 Colo J Intl Envtl L \& Poly 283.

Eckert, Ross "Ocean Enclosures: A Better Way to Manage Marine Resources" in Robert L Friedheim (ed) Managing Ocean Resources: A Primer (Westview Press, Boulder, Colorado, 1979) 91.

Edeson, William "The International Plan of Action on Illegal Unreported and Unregulated Fishing: The Legal Context of a Non-Legally Binding Instrument" (2001) 16 (4) IJMCL 603.

Edeson, William R "A Brief Introduction to the Principle Provisions of the International Legal Regime Governing Fisheries in the EEZ" in Syma A Ebbin, Alf Hakon Hoel and Are K Sydnes (eds) A Sea Change: The Exclusive Economic Zone and Governance Institutions for Living Marine Resources (Springer, Dordrecht, 2005) 17.

Eichenberg, Tim and Mitchell Shapson "The Promise of Johannesburg: Fisheries and the World Summit on Sustainable Development" (2004) 34 Golden Gate U L Rev 587. 
Eiriksson, Gudmundur "The Working Methods of the International Tribunal for the Law of the Sea" in Myron H Nordquist and John Norton Moore (eds) Oceans Policy: New Institutions, Challenges and Opportunities (Kluwer Law International, The Hague, 1999) 111.

El-Baghdadi, Mahdi "The Binding Nature of the Disputes Settlement Procedure in the Third U.N. Convention on the Law of the Sea: The International Seabed Authority" (1990/1991) 6 J Min L \& Poly 173.

Elferink, Alex G Oude "The Continental Shelf Beyond 200 Nautical Miles: The Relationship Between the CLCS and Third Part Dispute Settlement" in Alex G Oude Elferink and Donald R Rothwell (eds) Oceans Management in the 21st Century: Institutional Frameworks and Responses (Martinus Nijhoff Publishers, Leiden, 2004) 107.

Erasmus, Gerhard "Dispute Settlement in the Law of the Sea" (1986) Acta Juridica 15.

Erceg, Diane "Deterring IUU Fishing through State Control over Nationals" (2006) 30 Marine Policy 173.

Escher, Anne-Katrin "Release of Vessels and Crews before the International Tribunal for the Law of the Sea" Part 1 and 2 (2004) 3 (2) LPICT 205.

Escher, Anne-Katrin "Release of Vessels and Crews before the International Tribunal for the Law of the Sea" Part 3 (2004) 3 (3) LPICT 411.

Esty, Daniel C and Maria H Ivanova "Revitalizing Global Environmental Governance: A Function-Driven Approach" in Daniel C Esty and Maria H Ivanova (eds) Global Environmental Governance: Options \& Opportunities (Yale School of Forestry \& Environmental Studies, New Haven, 2002) 181.

Ettinger, Jan van Alexander King and Peter Payoyo "Ocean Governance and the Global Picture" in Peter Bautista Payoyo (ed) Ocean Governance: Sustainable Development of the Seas (United Nations University Press, Tokyo, 1994) 247.

Evans, Malcolm D "The M/V Saiga: The First Case in the International Tribunal for the Law of the Sea" (1999) 48 ICLQ 187.

Evans, Malcolm D "The Southern Bluefin Tuna Dispute: Provisional Thinking on Provisional Measures?” (1999) 10 YIEL 7.

Evans, Malcolm D "Bonded Reason: The Camouco" (2000) Lloyd's Maritime \& Commercial Law Quarterly 315.

Fabra, Adriana "The LOSC and the Implementation of the Precautionary Principle" (1999) 10 YIEL 15. 
Fallon, Liza D and Lorne K Kriwoken "International Influence of an Australian Nongovernment Organization in the Protection of Patagonian Toothfish" (2004) 35 ODIL 221.

Fayette, Louise de La "International Tribunal for the Law of the Sea: The M/V 'Saiga' (No.2) Case (St. Vincent and the Grenadines v Guinea), Judgment" (2000) 49 ICLQ 467.

Fayette, Louise de La "ITLOS and the Saga of the Saiga: Peaceful Settlement of a Law of the Sea Dispute" (2000) 15 (3) IJMCL 355.

Ferrell, Jessica K "Controlling Flags of Convenience: One Measure to Stop Overfishing of Collapsing Fish Stocks" (2005) 35 Envtl L 323.

Fiss, Owen M “Against Settlement” (1984) 93 Yale L J 1073.

Fitzmaurice, Gerald "The Future of Public International Law and of the International Legal System in the Circumstances of Today" in Institut de Droit International Livre du Centenaire 1873-1973: Evolution et Perspectives du Droit International (S Karger, Basel, 1963) 276.

Fleischhauer, Carl-August "The Relationship Between the International Court of the Justice and the Newly Created International Tribunal for the Law of the Sea in Hamburg" (1997) 1 Max Planck Yrbk UN L 327.

Foster, Caroline E "The 'Real Dispute' in the Southern Bluefin Tuna Case: A Scientific Dispute?” (2001) 16 (4) IJMCL 571.

Foster, Elizabeth G and Marcus Haward "Integrated Management Councils: A Conceptual Model for Ocean Policy Conflict Management in Australia" (2003) 46 Ocean \& Coastal Management 547.

Foster, Elizabeth, Marcus Haward and Scott Coffen-Smout "Implementing Integrated Oceans Management: Australia's South East Regional Marine Plan (SERMP) and Canada's Eastern Scotian Shelf Integrated Management (ESSIM) Initiative" (2005) 29 Marine Policy 391.

Forster, Malcolm J C "The MOX Plant Case - Provisional Measures in the International Tribunal for the Law of the Sea" (2003) 16 LJIL 611.

Fortier, Yves L "From Confrontation to Cooperation on the High Seas: Recent Developments in International Law Concerning the Conservation of Marine Resources" in Nisuke Endo and others (eds) Liber Amicorum Judge Shigeru Oda (vol 2, Kluwer Law International, The Hague, 2002) 1377.

Franckx, Erik "Pacta Tertiis and the Agreement for the Implementation of the Straddling and Highly Migratory Fish Stocks Provisions of the United Nations Convention on the Law of the Sea" (2000) 8 Tul J Intl \& Comp L 49. 
Franckx, Erik "'Reasonable Bond' in the Practice of the International Tribunal for the Law of the Sea" (2002) 32 Cal W Intl L J 303.

Freestone, David “Caution or Precaution: 'A Rose by Any Other Name...'?" (1999) 10 YIEL 27.

Friedheim, Robert L "A Proper Order for the Oceans: An Agenda for the New Century" in Davor Vidas and Willy Østreng (eds) Order for the Oceans at the Turn of the Century (Kluwer Law International, The Hague, 1999) 537.

Friedheim, Robert L "Ocean Governance at the Millennium: Where We Have Been - Where We Should Go" (1999) 42 Ocean \& Coastal Management 747.

Fye, Paul M and others "Ocean Science and Marine Resources" in Uses of the Seas (Prentice-Hall Inc, Englewood Cliffs (New Jersey), 1968).

Gaertner, Marianne P "The Dispute Settlement Provisions of the Convention on the Law of the Sea: Critique and Alternatives to the International Tribunal for the Law of the Sea" (1982) 19 San Diego L Rev 577.

Gamble Jr, John King "The Law of the Sea Conference: Dispute Settlement in Perspective" (1976) 9 Vand J Transnatl L 323.

Gamble Jr, John King "The 1982 UN Convention on the Law of the Sea: Binding Dispute Settlement?” (1991) 9 B U Intl L J 39.

Garcia, S M and M Hayashi "Division of the Oceans and Ecosystem Management: A Contrastive Spatial Evolution of Marine Fisheries Governance" (2000) 43 Ocean \& Coastal Management 445.

Garrett, John Norton "Hydrocarbons on the Continental Margins: Some of the Issues Addressed in the UNCLOS III Negotiations" in Douglas M Johnston and Norman G Letalik (eds) in The Law of the Sea and Ocean Industry: New Opportunities and Restraints (Law of the Sea Institute, University of Hawaii, Honolulu, 1983) 420.

Gathii, James "Fairness As Fidelity to Making the WTO Fully Responsive to All its Members" in Is the International Trade Regime Fair to Developing States? (2003) 97 Am Socy Intl L Proc 153.

Gault, Ian Townsend "The Impact of Offshore Petroleum Regimes on Other Sea Users: The North Sea and North America" in Douglas M Johnston and Norman G Letalik (eds) in The Law of the Sea and Ocean Industry: New Opportunities and Restraints (Law of the Sea Institute, University of Hawaii, Honolulu, 1983) 411.

Gautier, Philippe "Interim Measures of Protection Before the International Tribunal for the Law of the Sea" in M H Nordquist and J N Moore (eds) Current Marine Environmental Issues and the International Tribunal for the Law of the Sea (Kluwer Law International, The Hague, 2001) 243. 
Gautier, Philippe "The International Tribunal for the Law of the Sea: Activities in 2002” (2003) 2 Chinese J of Intl L 341.

Gautier, Philippe "The International Tribunal for the Law of the Sea: Activities in 2003" (2004) 3 Chinese J Intl L 241.

Gemmill, Barbara and Abimbola Bamidele-Izu "The Role of NGO's and Civil Society in Global Environmental Governance" in Daniel C Esty and Maria H Ivanova (eds) Global Environmental Governance: Options \& Opportunities (Yale School of Forestry \& Environmental Studies, New Haven, 2002) 77.

Gillespie, Alexander "The Search for a New Compliance Mechanism Within the International Whaling Commission” (2003) 34 ODIL 349.

Gislason, Henrik and others "Symposium Overview: Incorporating Ecosystem Objectives Within Fisheries Management" (2000) 57 ICES Journal of Marine Science 468.

Goff, Phil "International Institutions and Governance: A New Zealand Perspective" (2004) 1 NZYIL 1.

Gold, Edgar "From Process to Reality: Adopting Domestic Legislation for the Implementation of the Law of the Sea Convention" in Davor Vidas and Willy Østreng (eds) Order for the Oceans at the Turn of the Century (Kluwer Law International, The Hague, 1999) 375.

Goldie, L F E "Development of an International Environmental Law - An Appraisal" in John Lawrence Hargrove (ed) Law, Institutions, and the Global Environment (Oceana Publications Inc, Dobbs Ferry (New York), 1972) 104.

Gorina-Ysern, Montserrat Kristina Gjerde and Michael Orbach "Ocean Governance: A New Ethos through a World Ocean Public Trust" in Linda K Glover and Sylvia A Earle (eds) Defying Ocean's End: An Agenda for Action (Island Press, Washington DC, 2004) 197.

Gormley, W Paul "The Development and Subsequent Influence of the Roman Legal Norm of "Freedom of the Seas"' (1963) 40 (5) U Det L J 561.

Góralczyk, Wojciech "Changing Attitudes of Central and Eastern European States Towards the Judicial Settlement of International Disputes" in Daniel Bardonnet (ed) The Peaceful Settlement of International Disputes in Europe: Future Prospects (Martinus Nijhoff Publishers, Dordrecht, 1991).

Greiner, R and others "Incentive Instruments for Sustainable Use of Marine Resources"(2000) 43 Ocean \& Coastal Management 29.

Guillaume, Gilbert "The Future of International Judicial Institutions" (1995) ICLQ 848. 
Gullett, Warwick "Prompt Release Procedures and the Challenge for Fisheries Law Enforcement: The Judgment of the International Tribunal for the Law of the Sea in the "Volga' Case (Russian Federation v Australia)" (2003) 31 Fed L Rev 395.

Guruswamy, Lakshman "The Promise of the United Nations Convention on the Law of the Sea (UNCLOS): Justice in Trade and Environment Disputes" (1998) 25 Ecology L Q 189.

Guzman, Andrew T "The Cost of Credibility: Explaining Resistance to Interstate Dispute Resolution Mechanisms" (2002) 31 J Legal Stud 303.

Haas, Peter $M$ "UN Conferences and Constructive Governance of the Environment" (2002) 8 Global Governance 73.

Hafner, Gerhard "Should One Fear the Proliferation of Mechanisms for the Peaceful Settlement of Disputes?" in Lucius Caflisch (ed) The Peaceful Settlement of Disputes Between States: Universal and European Perspectives (Kluwer Law International, The Hague, 1998) 25.

Hanna, Susan S "Strengthening Governance of Ocean Fishery Resources" (1999) 31 Ecological Economics 275.

Hardin, Garrett "The Tragedy of the Commons" (1968) 162 Science 1243.

Hardin, Garrett "Extensions of the "Tragedy of the Commons'" (1998) 280 Science 682.

Hassan, Daud "International Conventions Relating to Land-based Sources of Marine Pollution Control: Applications and Shortcomings" (2004) 16 Geo Intl Envtl L Rev 657.

Haubert, Wm H II "Toward Peaceful Settlement of Ocean Space Disputes: A Working Paper" (1974) 11 San Diego L Rev 733.

Haward, Marcus "IUU Fishing: Contemporary Practice" in Alex G Oude Elferink and Donald R Rothwell (eds) Oceans Management in the 21st Century: Institutional Frameworks and Responses (Martinus Nijhoff Publishers, Leiden, 2004) 87.

Hayashi, Moritaka "The Southern Bluefin Tuna Cases: Prescription of Provisonal Measures by the International Tribunal for the Law of the Sea" (2000) 13 Tul Envtl L J 361.

Hayashi, Moritaka "Illegal, Unreported, and Unregulated Fishing: Global and Regional Responses" in David D Caron and Harry N Scheiber (eds) Bringing New Law to Ocean Waters (Martinus Nijhoff Publishers, Leiden, 2004) 95. 
Hegwood, David "DeepSeabed Mining: Alternative Scheme for Protecting Developing Countries from Adverse Impacts" (1982) 12 Ga J Intl \& Comp L 173.

Helfer, Laurence R and Anne-Marie Slaughter "Toward a Theory of Effective Supranational Adjudication" (1997) 107 Yale L J 273.

Helfer, Laurence R and Anne-Marie Slaughter "Why States Create International Tribunals: A Response to Professors Posner and Yoo" (2005) 93 Cal L Rev 899.

Hemmings, Alan D "Managing the Southern Ocean - the 2003 Meeting of the Commission for the Conservation of Antarctic Marine Living Resources" (2004) 1 NZYIL 199.

Henderson, Hazel "New Markets and New Commons" (1995) 27 (2) Futures 113.

Hennessey, Timothy M "Multiple Uses of International Marine Resources: Theoretical Considerations" in Douglas M Johnston and Norman G Letalik (eds) in The Law of the Sea and Ocean Industry: New Opportunities and Restraints (Law of the Sea Institute, University of Hawaii, Honolulu, 1983) 34.

Herbert, Glen J and Timothy M Shaw "Oceans Governance and Human Security Towards the End of the Century: Regional Approaches" in Aldo Chircop, Andre Gerolymatos and John O Iatrides (eds) The Aegean Sea After the Cold War: Security and Law of the Sea Issues (Macmillan Press, London, 2000) 206.

Hey, Ellen "Increasing Accountability for the Conservation and Sustainable Use of Biodiversity: A Question of Transnational Global Character" (1995) 6 Colo J Intl Envtl L \& Poly 1.

Highet, Keith "Maritime Boundary Disputes and Settlement" in Mochtar Kusuma Atmadja, Thomas A Mensah and Bernard H Oxman (eds) Sustainable Development and Preservation of the Oceans: The Challenges of UNCLOS and Agenda 21 (The Law of the Sea Institute, University of Hawaii, Honolulu, 1997) 745.

Hinds, Lennox "Oceans Governance and the Implementation Gap" (2003) 27 Marine Policy 349.

Hoel, Alf Hakon and Ingrid Kvalik "The Allocation of Scarce Natural Resources: The Case of Fisheries" (Article in Press) Marine Policy.

Hoel, Alf Hakon, Are K Sydnes and Syma A Ebbin "Ocean Governance and Institutional Change" in Syma A Ebbin, Alf Hakon Hoel and Are K Sydnes (eds) A Sea Change: The Exclusive Economic Zone and Governance Institutions for Living Marine Resources (Springer, Dordrecht, 2005) 3.

Holland, G L "The Role of Intergovernmental Organizations in Coastal Zone Management" (1998) 39 Ocean \& Coastal Management 25. 
Horowitz, Deborah “The Catch of Poseidon's Trident: The Fate of High Seas Fisheries in the Southern Bluefin Tuna Case" (2001) 25 Melb U L Rev 810.

Howe, Nick "ITLOS - A Practitioner's Perspective" in M H Nordquist and J N Moore (eds) Current Marine Environmental Issues and the International Tribunal for the Law of the Sea (Kluwer Law International, The Hague, 2001) 159.

Hunt, Colin "Concern for Southern Ocean Fish Stocks and Bird Populations" Marine Policy (Article in Press).

Huntington, Samuel P “The Clash of Civilizations?” (1993) 72 (3) Foreign Affairs 22.

Hurst, Cecil J B “Wanted! An International Court of Piepowder” (1925) 6 BYIL 61.

International Group of Experts "Dispute Avoidance and Dispute Settlement in Internatinal Environmental Law - Conclusions by the International Group of Experts" (1999) 29 (2-3) Envtl Poly \& L 143.

Irwin, Paul C "Settlement of Maritime Boundary Disputes: An Analysis of the Law of the Sea Negotiations" (1980) 8 (2) ODIL 105.

Jackson, John H "GATT as an Instrument for the Settlement of Trade Disputes" (1967) 61 Am Socy Intl L Proc 144.

Jacovides, Andreas J "Peaceful Settlement of Disputes in Ocean Conflicts: Does UNCLOS III Point the Way?" in Thomas Buergenthal (ed) Contemporary Issues in International Law, Essays in Honor of Louis B Sohn (N P Engel Publisher, Kehl, 1984) 165.

Jacovides, Andrew A "International Tribunals: Do They Really Work for Small States?" (2001) 34 N Y U J Intl L \& Pol 253.

Jaenicke, Günther "Dispute Settlement under the Convention of the Law of the Sea” (1983) 43 (4) ZaöRV 813.

Jaenicke, Günther "The Interpretation of the Law of the Sea Convention in the Jurisprudence of the International Tribunal for the Law of the Sea" in Nisuke Endo and others (eds) Liber Amicorum Judge Shigeru Oda (vol 1, Kluwer Law International, The Hague, 2002) 683.

Janis, Mark W "Dispute Settlement in the Law of the Sea Convention: The Military Activities Exception” (1977) 4 (1) ODIL 51.

Janis, Mark W "The Law of the Sea Tribunal" in Mark W Janis (ed) International Courts for the Twenty - First Century (Martinus Nijhoff Publishers, Dordrecht, 1992) 245. 
Jennings, Robert "Need for Environmental Court?" (1992) 22 Envtl Poly \& L 312.

Jennings, Robert "The Difference between Conducting a Case in the ICJ and an ad hoc Arbitration Tribunal - An Inside View" in Nisuke Endo and others (eds) Liber Amicorum Judge Shigeru Oda (vol 2, Kluwer Law International, The Hague, 2002) 893.

Johnston, Douglas M "The Environmental Law of the Sea: Historical Development" in Douglas M Johnston (ed) The Environmental Law of the Sea (IUCN Environmental Policy and Law Paper No 18, IUCN, Gland, Switzerland, 1981) 17.

Johnston, Douglas M "Ocean Governance: Converging Modes of Idealism" in Jon M Van Dyke, Durwood Zaelke and Grant Hewison (eds) Freedom for the Seas in the 21st Century: Ocean Governance and Environmental Harmony (Island Press, Washington DC, 1993) 471.

Johnston, Douglas $M$ "Fishery Diplomacy and Science and the Judicial Function" (1999) 10 YIEL 33.

Joyner, Christopher C "Compliance and Enforcement in New International Fisheries Law” (1998) 12 Temp Intl \& Comp L J 271.

Juda, Lawrence "Changing National Approaches to Ocean Governance: The United States, Canada and Australia" (2003) 34 ODIL 161.

Juda, Lawrence "Changing Perspectives on the Oceans: Implications for International Fisheries and Ocean Governance" in David D Caron and Harry N Scheiber (eds) Bringing New Law to Ocean Waters (Martinus Nijhoff Publishers, Leiden, 2004) 17.

Karkkainen, Bradley "Marine Ecosystem Management \& a 'Post-Sovereign' Transboundary Governance" (2004) San Diego Intl L J 113.

Kaye, Stuart "Negotiation and Dispute Resolution: A Case Study in International Boundary Making - The Australia-Indonesia Boundary" in Alex G Oude Elferink and Donald R Rothwell (eds) Ocean Management in the $21^{\text {st }}$ Century: Institutional Frameworks and Responses (Martinus Nijhoff Publishers Publishers, Leiden, 2004) 143.

Kennedy, David "New Approaches to Comparative Law: Comparativism and International Governance" (1997) 1997 Utah L Rev 545

Kennedy, Kevin "Preferential Treatment of Developing Countries" in Raj Bhala and Kevin Kennedy World Trade Law: The GATT-WTO System, Regional Arrangements and U.S. Law (Lexis Law Publishing, Charlottesville, Virginia, 1999) 339. 
Keohane, Robert O, Andrew Moravcsik and Anne-Marie Slaughter "Legalized Dispute Resolution: Interstate and Transnational” (2000) 54 (3) Intl Org 457.

Keohane, Robert O and Joseph S Nye Jr "Introduction" in Joseph S Nye and John D Donahue (eds) Governance in a Globalising World (Visions of Governance for the 21st Century, Cambridge (Mass), 2000) 1.

Kesteven, G L "Fisheries Research in Developing Countries" in Brian J Rothschild (ed) Global Fisheries: Perspectives for the 1980s (Springer - Verlag, New York, 1983) 247.

Khan, Rahmatullah "The Thickening Web of International Law" in Issues in Global Governance: Papers Written for the Commission on Global Governance (Kluwer Law International, London, 1995) 249.

Kibel, Paul Stanton “Alone at Sea: Chile's Presencial Ocean Policy” (2000) 12 (1) J Envtl L 43.

Kieves, Nicola "Crisis at Sea: Strengthening Government Regulation to Save Marine Fisheries" (2005) 89 Minn L Rev 1876.

Kimball, Lee A "The Role of NGOs in the Implementation of the 1982 LOS Convention" in Alfred H A Soons (ed) Implementation of the Law of the Sea Convention through International Institutions (Law of the Sea Institute, University of Hawaii, Honolulu, 1990) 139.

Kimball, Lee A "The United Nations Convention on the Law of the Sea: A Framework for Marine Conservation" in IUCN The Law of the Sea: Priorities and Responsibilities in Implementing the Convention (IUCN, Gland, 1995) 1.

Kimball, Lee A "Whither International Institutional Arrangements to Support Ocean Law” (1997) 36 Colum J Transnatl L 307.

Kimball, Lee A "Major Challenges of Ocean Governance: The Role of NGOs" in Davor Vidas and Willy Østreng (eds) Order for the Oceans at the Turn of the Century (Kluwer Law International, The Hague, 1999) 389.

Kindt, John Warren "The Effect of Claims by Developing Countries On LOS International Marine Pollution Negotiations" (1980) 20 (2) Va J Intl L 313.

Kindt, John Warren "Dispute Settlement in International Environmental Issues: The Model provided by the 1982 Convention on the Law of the Sea" (1989) 22 Vand J Transnatl L 1097.

Kingsbury, Benedict 'Is the Proliferation of International Courts and Tribunals a Systemic Problem?” (1999) 31 N Y U J Intl L \& Pol 679. 
Knecht, Robert W "A Perspective on Recent Developments that Could Affect the Nature of Ocean Governance Regimes" in Thomas A Mensah (ed) Ocean Governance: Strategies and Approaches for the $21^{\text {st }}$ Century (The Law of the Sea Institute, University of Hawaii, Honolulu, 1994) 177.

Knecht, Robert W "Coordination of Policy and Law Within Nation-States: Implications of Linkage Between National and International Political Forces in Achieving Sustainable Use of the Oceans" in Mochtar Kusuma Atmadja, Thomas A Mensah and Bernard H Oxman (eds) Sustainable Development and Preservation of the Oceans: The Challenges of UNCLOS and Agenda 21 (The Law of the Sea Institute, University of Hawaii, Honolulu, 1997) 408.

Koch-Weser, Maritta R v B "Sustaining Global Environmental Governance: Innovation in Environment and Development Finance" Daniel C Esty and Maria H Ivanova (eds) Global Environmental Governance: Options \& Opportunities (Yale School of Forestry \& Environmental Studies, New Haven, 2002) 141.

Koh, Kheng Lian and Nicholas A Robinson "Regional Environmental Governance: Examining the Association of Southeast Asian Nations (ASEAN) Model" in Daniel C Esty and Maria H Ivanova (eds) Global Environmental Governance: Options \& Opportunities (Yale School of Forestry \& Environmental Studies, New Haven, 2002) 101.

Kolodkin, Anatoly L "National Legislation in the Light of UNCLOS and the Practice of the International Tribunal for the Law of the Sea" in M H Nordquist and J N Moore (eds) Current Marine Environmental Issues and the International Tribunal for the Law of the Sea (Kluwer Law International, The Hague, 2001) 239.

Konig, Doris "The Enforcement of the International Law of the Sea by Coastal and Port States" (2002) 62 (1-2) ZaöRV 1.

Kooijmans, Peter H "The International Court of Justice: Where Does it Stand?" in A S Muller, D Raič and J M Thuránszky (eds) The International Court of Justice: Its Role after 50 Years (Martinus Nijhoff Publishers Publishers, The Hague, 1997) 407.

Koroma, Abdul G "Implementation of the Law of the Sea Convention Through Its Institutions: An Overview" in Davor Vidas and Willy Østreng (eds) Order for the Oceans at the Turn of the Century (Kluwer Law International, The Hague, 1999) 57.

Koskenniemi, Martti "Peaceful Settlement of Environmental Disputes" (1991) 60 Nordic J Intl L73.

Kriesberg, Louis "The Development of the Conflict Resolution Field" in I William Zartman and J Lewis Rasmussen (eds) Peacemaking in International Conflict (United States Institute of Peace Press, Washington DC, 1997) 64. 
Kwaitkowska, Barbara "Institutional Marine Affairs Cooperation in Developing State Regions': Part I: General Problems and Prospects" (1990) 14 Marine Policy 385.

Kwaitkowska, Barbara "Institutional Marine Affairs Cooperation in Developing State Regions: Part II: The Indian Ocean and IOMAC" (1990) 14 Marine Policy 399.

Kwiatkowska, Barbara "The Saint Vincent and the Grenadines v Guinea M/V Saiga Cases" (1998) 11 LJIL 547.

Kwiatkowska, Barbara "Inauguration of the ITLOS Jurisprudence: The Saint Vincent and the Grenadines v. Guinea M/V Saiga Cases" (1999) 30 ODIL 43.

Kwiatkowska, Barbara "The Future of the Law of the Sea Tribunal in Hamburg" in Wybo P Heere (ed) International Law and The Hague's $750^{\text {th }}$ Anniversary (TMC Asser Press, The Hague, 1999) 417.

Kwiatkowska, Barbara "The Saint Vincent and the Grenadines v. Guinea M/V Saiga Cases before the International Tribunal for the Law of the Sea" in Donald R Rothwell and Sam Bateman (eds) Navigational Rights and Freedoms and the New Law of the Sea (Kluwer Law International, The Hague, 2000) 275.

Kwiatkowska, Barbara "The Australia and New Zealand v Japan Southern Bluefin Tuna (Jurisdiction and Admissibility) Award of the First Law of the Sea Convention Annex VII Arbitral Tribunal” (2001) 16 (2) IJMCL 239.

Kwiatkowska, Barbara "The Southern Bluefin Tuna Award (Jurisdiction and Admissibility) in Nisuke Endo and others (eds) Liber Amicorum Judge Shigeru Oda (vol 1, Kluwer Law International, The Hague, 2002) 697.

Kwiatkowska, Barbara "The Southern Bluefin Tuna Arbitral Tribunal Did Get it Right: A Commentary and Reply to the Article by David A. Colson and Dr. Peggy Hoyle" (2003) 34 ODIL 369.

Kwiatkowska, Barbara "The Ireland $v$ United Kingdom (Mox Plant) Case: Applying the Doctrine of Treaty Parallelism" (2003) 18 (1) IJMCL 1.

Lachs, Manfred "Arbitration and International Adjudication" in A H A Soons (ed) International Arbitration: Past and Prospects (Martinus Nijhoff Publishers Publishers, Dordrecht, 1990) 37.

Lagoni, Rainer "The Prompt Release of Vessels and Crews before the International Tribunal for the Law of the Sea: A Preparatory Report" (1996) 11 (2) IJMCL 147.

Laing, Edward A "Equal Access/ Non-discrimination and Legitimate Discrimination in International Economic Law" (1996) 14 Wis Intl L J 246. 
Laing, Edward Arthur "A Perspective on Provisional Measures under UNCLOS" (1998) 29 NYIL 45.

Laing, Edward Arthur "ITLOS Procedures and Practices: Bonds" in $\mathrm{M} \mathrm{H}$ Nordquist and J N Moore (eds) Current Marine Environmental Issues and the International Tribunal for the Law of the Sea (Kluwer Law International, The Hague, 2001) 113.

Lang, Winfried "Trade and Positive Measures in Multilateral Environmental Agreements: Effectiveness and Suitability" in Wybo P Heere (ed) International Law and The Hague's $750^{\text {th }}$ Anniversary (TMC Asser Press, The Hague, 1999) 317.

Lauterpacht, Eli "The First Decision of the International Tribunal for the Law of the Sea: The M/V Saiga" in Gerhard Hafner and others (eds) Liber Amicorum Professor Seidl-Hohenveldern - In Honour of His 80 ${ }^{\text {th }}$ Birthday (Kluwer Law International, The Hague, 1998) 395.

Lauterpacht, Hersch "The Judicial Settlement of International Disputes" in Elihu Lauterpacht (ed) International Law: Being the Collected Papers of Hersch Lauterpacht (vol 5, Cambridge University Press, Cambridge, 2004) 72.

Leary, David and Anshuman Chakraborty and "New Horizons in the Law of the Sea" (2005) 36 VUWLR 675.

Lee, Roy S “Towards a More Proactive System of Dispute Settlement” in Nisuke Endo and others (eds) Liber Amicorum Judge Shigeru Oda (vol 2, Kluwer Law International, The Hague, 2002) 923.

Le Gallic, Betrand and Anthony Cox "An Economic Analysis of Illegal, Unreported and Unregulated (IUU) Fishing: Key Drivers and Possible Solutions" Marine Policy (Article in Press).

Little, Laura and Marcos A Orellana "Can CITES Play a Role in Solving the Problem of IUU Fishing?: The Trouble with Patagonian Toothfish" (2004) Yearbook Colo J Envtl L \& Poly 21.

Lodge, Michale W and Satya N Nandan "Some Suggestions Towards Better Implementation of the United Nations Agreement on Straddling Fish Stocks and Highly Migratory Fish Stocks of 1995" (2005) 20 (2 - 3) IJMCL 345.

Loibl, Gerhard "Trade and Environment - A Difficult Relationship New Approaches and Trends: The Kyoto Protocol and Beyond" in Gerhard Hafner and others (eds) Liber Amicorum Professor Seidl-Hohenveldern - In Honour of His $80^{\text {th }}$ Birthday (Kluwer Law International, The Hague, 1998) 419.

Loibl, Gerhard "Reporting and Information Systems in International Environmental Agreements as a Means of Dispute Prevention - The Role of 'International Institutions"' (2005) 5 Non-State Actors \& Intl L 1. 
Lowe, Vaughan "Overlapping Jurisdiction in International Tribunal" (1999) 20 Aust YBIL 191.

Lowe, Vaughan "The M/V Saiga: The First Case in the International Tribunal for the Law of the Sea" (1999) 48 ICLQ 187.

Lowe, Vaughan "International Tribunal for the Law of the Sea: Survey for 2000" (2001) 16 (4) IJMCL 549.

Lowe, Vaughan and Robin Churchill "International Tribunal for the Law of the Sea: Survey for 2001" (2002) 17 (4) IJMCL 463.

Malia, Gerald A “The New 'International Tribunal for the Law of the Sea': Prospects for Dispute Resolution at the 'Sea Court"” (1995) 7 Geo Intl Envtl L Rev 791.

Manner, Eero J "Settlement of Sea-Boundary Delimitation Disputes According to the Provisions of the 1982 Law of the Sea Convention" in Jerzy Makarczyk (ed) Essays in International Law in Honour of Judge Manfred Lachs (Martinus Nijhoff Publishers Publishers, The Hague, 1984) 625.

Mansfield, Bill "The Southern Bluefin Tuna Arbitration: Comments on Professor Barbara Kwiatkowska's Article" (2001) 16 (2) IJMCL 361.

Mansfield, Bill "Compulsory Dispute Settlement after the Southern Bluefin Tuna Award" in Alex G Oude Elferink and Donald R Rothwell (eds) Oceans Management in the 21st Century: Institutional Frameworks and Responses (Martinus Nijhoff Publishers Publishers, Leiden, 2004) 255.

Marr, Simon "The Southern Bluefin Tuna Cases: The Precautionary Approach and Conservation and Management of Fish Resources" (2000) 11 (4) EJIL 815.

Martin, Laurence "The Role of Force in the Ocean" in Perspectives on Ocean Policy: Conference on Conflict and Order in Ocean Relations October 21-24, 1974, Airlie, Virginia (National Science Foundation, Washington DC, 1975) 33.

Mason, Anthony "International Law as a Source of Domestic Law" in Brian R Opeskin and Donald R Rothwell (eds) International Law and Australian Federalism (Melbourne University Press, Carlton South, Victoria, 1997) 210.

Mawdsley, Andrés Aguilar "Law of the Sea: The Latin American View" in Giulio Pontecorvo (ed) The New Order of the Oceans: The Advent of a Managed Environment (Columbia University Press, New York, 1986) 156.

McCullagh, James "International Legal Control Over Accelerating Ocean Storage of Carbon Dioxide," in Bill Ormerod (ed) Ocean Storage of Carbon Dioxide: Workshop 3 - International Links and Concerns (IEA Greenhouse Gas R\&D Programme, Cheltenham, 1996) 85. 
McDorman, Ted L and Aldo Chircop "The Resolution of Maritime Disputes" in Edgar Gold (ed) Maritime Affairs: A World Handbook (Longman Group UK, Harlow, Essex, 1991) 344 .

McDorman, Ted L "The Search for Resolution of the Canada - France Ocean Dispute Adjacent to St. Pierre and Miquelon" (1994) 17 (1) Dal L J 35.

McDorman, Ted L "Stateless Fishing Vessels, International Law and the UN High Seas Fisheries Conference" (1994) 25 (4) J Mar L \& Com 531.

McDorman, Ted L "Ocean Dispute Settlement in the Baltic Sea" in Renate Platzöder and Philomene Verlaan (eds) The Baltic Sea: New Developments in National Policies and International Co-operation (Martinus Nijhoff Publishers Publishers, The Hague, 1996) 189.

McDorman, Ted L "The Dispute Settlement Regime of the Straddling and Highly Migratory Fish Stocks Convention” (1997) 35 Can YIL 57.

McDorman, Ted L "Dispute Settlement and the Law of the Sea with Special Reference to the Aegean Sea" in Aldo Chircop, Andre Gerolymatos and John O Iatrides (eds) The Aegean Sea After the Cold War: Security and Law of the Sea Issues (Macmillan Press, London, 2000) 225.

McDorman, Ted L "Global Ocean Governance and International Adjudicative Dispute Resolution" (2000) 43 Ocean \& Coastal Management 255.

McDorman, Ted L "International Tribunal for the Law of the Sea (ITLOS)" (2002) 13 YIEL 673.

McDorman, Ted L "An Overview of International Fisheries Disputes and the International Tribunal for the Law of the Sea" (2002) 40 Can YIL 119.

McDorman, Ted L "The Role of the Commission on the Limits of the Continental Shelf: A Technical Body in a Political World" (2002) 17 IJMCL 301.

McDorman, Ted L "OSPAR Convention - Access to Information Environmental Information - Interpretation of Treaties" (2004) 98 AJIL 330.

McDougal, Myres S and Norbert A Schlei "The Hydrogen Bomb Tests in Perspective: Lawful Measures for Security" (1954-1955) 64 Yale L J 648.

McLachlan, Campbell "The Principle of Systemic Integration and Article 31 (3) (C) of the Vienna Convention" (2005) 54 ICLQ 279.

McLaughlin, Richard J "Free Trade, GATT, and Ocean Governance" (1994) 23 Ocean \& Coastal Management 65.

McWhinney, Edward "Judicial Settlement of Disputes: Jurisdiction and Justiciability” (1990 II) Recueil des Cours 19. 
Meeson, Nigel K “A Prompt but Controversial Decision for Prompt Release: The Saiga” (1998) Lloyd's Maritime \& Commercial Law Quarterly 485.

Mendez, Ruben P "Ocean Governance: The Question of Financing" in Peter Bautista Payoyo (ed) Ocean Governance: Sustainable Development of the Seas (United Nations University Press, Tokyo, 1994) 309.

Mengerink, Kathryn J "The Pew Oceans Committee Report: Navigating a Route to Sustainable Seas" (2004) 31 Ecology L Q 689.

Mensah, Thomas A "The Competent International Organizations: Internal and External Changes" in Peter Bautista Payoyo (ed) Ocean Governance: Sustainable Development of the Seas (United Nations University Press, Tokyo, 1994) 278.

Mensah, Thomas A "The International Tribunal and the Protection and Preservation of the Marine Environment" (1998) 28/5 Environmental Policy \& Law 216.

Mensah, Thomas A "The Dispute Settlement Regime of the 1982 United Nations Convention on the Law of the Sea" (1998) 2 Max Planck Yrbk UN L 307.

Mensah, Thomas "The International Tribunal for the Law of the Sea" (1998) 11 LJIL 527.

Mensah, Thomas "The International Tribunal for the Law of the Sea: The First Year" in Myron H Nordquist and John Norton Moore (eds) Oceans Policy: New Institutions, Challenges and Opportunities (Kluwer Law International, The Hague, 1999) 73.

Mensah, Thomas A "Role of Peaceful Dispute Settlement in Contemporary Ocean Policy and Law" in Davor Vidas and Willy Østreng (eds) Order for the Oceans at the Turn of the Century (Kluwer Law International, The Hague, 1999) 81.

Mensah, Thomas A "The International Tribunal for the Law of the Sea and the Protection and Preservation of the Marine Environment" (1999) 8 (1) RECIEL 1.

Mensah, Thomas A "The Place of the International Tribunal for the Law of the Sea in the International System for the Peaceful Settlement of Disputes" in P Chandrasekhara Rao and Rahmatullah Khan (eds) International Tribunal for the Law of the Sea: Law and Practice (Kluwer Law International, The Hague, 2001) 21.

Mensah, Thomas A "Provisional Measures in the International Tribunal for the Law of the Sea (ITLOS)" (2002) 62 (1-2) ZaöRV 43. 
Mensah, Thomas A "Protection and Preservation of the Marine Environment and the Dispute Settlement Regime in the United Nations Convention on the Law of the Sea" in Andree Kirchner (ed) International Maritime Environmental Law: Institutions, Implementation and Innovations (Kluwer Law International, London, 2003) 9.

Miles, Edward "On the Role of International Organizations in the New Ocean Regime" in Choon-ho Park (ed) The Law of the Sea in the 1980s (Law of the Sea Institute, University of Hawaii, Honolulu, 1983) 383.

Miles, Edward L "Future Challenges in Ocean Management: Towards Integrated National Ocean Policy" in Paolo Fabbri (ed) Ocean Management in Global Change (Elsevier Applied Science, London, 1992) 595

Miles, Edward L "Implementation of International Regimes: A Typology" in Davor Vidas and Willy Østreng (eds) Order for the Oceans at the Turn of the Century (Kluwer Law International, The Hague, 1999) 327.

Miles, Edward L "The Concept of Ocean Governance: Evolution towards the $21^{\text {st }}$ Century and the Principle of Sustainable Ocean Use" (1999) 27 Coastal Management 1.

Miller, Susan Elliott "Environmental Considerations in Hawaii Ocean Governance" in Thomas A Mensah (Program Chairman) Ocean Governance for Hawaii (No 3, Special Publication, Law of the Sea Institute, Honolulu, 1995) 115.

Molenaar, Erik Jaap "Regional Fisheries Management Organizations: issues of Participation, Allocation and Unregulated Fishing" in Alex G Oude Elferink and Donald R Rothwell (eds) Oceans Management in the 21st Century: Institutional Frameworks and Responses (Martinus Nijhoff Publishers Publishers, Leiden, 2004) 69.

Morgan, Donald L “A Practitioner's Critique of the Order Granting Provisional Measures in the Southern Bluefin Tuna Cases" in M H Nordquist and J N Moore (eds) Current Marine Environmental Issues and the International Tribunal for the Law of the Sea (Kluwer Law International, The Hague, 2001) 173.

Morgan, Donald L "Emerging Fora for International Litigation (Part 1): Implications of the Proliferation of International Legal Fora: The Example of the Southern Bluefin Tuna Cases” (2002) 43 Harv Intl L J 541.

Mossop, Joanna "Book Review: Dispute Settlement in the UN Convention on the Law of the Sea" (2005) 36 VUWLR 867.

Ndiaye, Tafsir Malick "Provisional Measures before the International Tribunal for the Law of the Sea" in M H Nordquist and J N Moore (eds) Current Marine Environmental Issues and the International Tribunal for the Law of the Sea (Kluwer Law International, The Hague, 2001) 95. 
Nichols, Sue David Monahan and Michael D Sutherland "Good Governance of Canada's Offshore and Coastal Zone: Towards and understanding of the Maritime Boundary Issues” (2000) 54 (4) Geomatica, 415.

Njenga, Frank X "Historical Background of the Evolution of the Exclusive Economic Zone and the Contribution of Africa" in Giulio Pontecorvo (ed) The New Order of the Oceans: The Advent of a Managed Environment (Columbia University Press, New York, 1986) 125.

Noyes, John E "Compulsory Third-Party Adjudication and the 1982 United Nations Convention on the Law of the Sea" (1989) 4 Conn J Intl L 675.

Noyes, John E "The Third-Party Dispute Settlement Provisions of the 1982 United Nations Convention on the Law of the Sea: Implications for States Parties and for Nonparties" in M H Nordquist and J N Moore (eds) Entry into Force of the Law of the Sea Convention (Martinus Nijhoff Publishers Publishers, The Hague, 1995) 213.

Noyes, John E "The International Tribunal for the Law of the Sea" (1998) 32 Cornell Intl L J 109.

Noyes, John E "Law of the Sea Dispute Settlement: Past, Present, and Future" (1999) 5 ILSA J Intl \& Comp L 301.

Oda, Shigeru "Some Reflections on the Dispute Settlement Clauses in the United Nations Convention on the Law of the Sea" in Jerzy Makarczyk (ed) Essays in International Law in Honour of Judge Manfred Lachs (Martinus Nijhoff Publishers Publishers, The Hague, 1984) 645.

Oda, Shigeru "Dispute Settlement Prospects in the Law of the Sea" (1995) 44 ICLQ 863.

Oda, Shigeru "The Compulsory Jurisdiction of the International Court of Justice: A Myth? A Statistical Analysis of Contentious Cases" (2000) 49 ICLQ 251.

Oellers-Frahm, Karin "Arbitration - A Promising Alternative of Dispute Settlement under the Law of the Sea Convention" (1995) 55/2 ZaöRV 457.

Oellers-Frahm, Karin "Multiplication of International Courts and Tribunals and Conflicting Jurisdiction - Problems and Possible Solutions" (2001) 5 Max Planck Yrbk UN L 67.

Oelofsen, P D "Some Comments on the Proposed Procedures for Dispute Settlement under a New Law of the Sea Convention" (1976) SAYIL 192.

O’Keefe, Roger "ITLOS Flags its Intent” (2000) 59 (3) CLJ 428. 
Olsen, Stephen B and others "A Global Network for Sustained Governance of Coastal Ecosystems" in Linda K Glover and Sylvia A Earle (eds) Defying Ocean's End: An Agenda for Action (Island Press, Washington DC, 2004) 151, 153.

Oppenheim, Adrienne J "The Plight of the Patagonian Toothfish: Lessons from the Volga Case" (2004) 30 Brook J Intl L 293.

Orellana, Marcos A "The Swordfish Dispute between the EU and Chile at the ITLOS and the WTO” (2002) 71 Nordic J Intl L 55.

Orellana, Marcos A "The Law on Highly Migratory Fish Stocks: ITLOS Jurisprudence in Context" (2004) 34 Golden Gate U L Rev 459.

Örebech, Peter, Ketill Sigurjonsson and Ted McDorman "The 1995 United Nations Straddling and Highly Migratory Fish Stocks Agreement: Management, Enforcement and Dispute Settlement" (1998) 13 (2) IJMCL 119.

Ostrom, Elinor and others "Revisiting the Commons: Local Lessons, Global Challenges” (1999) 284 Science 278.

Oxman, Bernard H "The Third United Nations Conference on the Law of the Sea: The 1976 New York Sessions" (1977) 71 AJIL 247.

Oxman, Bernard H "The Third United Nations Conference on the Law of the Sea: The 1977 New York Session” (1978) 72 AJIL 57.

Oxman, Bernard H "The Third United Nations Conference on the Law of the Sea: The Seventh Session (1978)" (1979) 73 AJIL 1.

Oxman, Bernard $\mathrm{H}$ "Observations on Vessel Release under the United Nations Convention on the Law of the Sea" (1996) 11 (2) IJMCL 201.

Oxman, Bernard H "Human Rights and the United Nations Convention on the Law of the Sea" (1997) 36 Colum J Transnatl L 399.

Oxman, Bernard $\mathrm{H}$ “The M/V 'Saiga' (Saint Vincent and the Grenadines v. Guinea)" (1998) 92 AJIL 278.

Oxman, Bernard and Vincent P Bantz "The M/V 'Saiga' (No. 2) (Saint Vincent and the Grenadines v, Guinea)" (2000) 94 AJIL 140.

Oxman, Bernard and Vincent P Bantz "Prompt Release of Vessels and Crews Exhaustion of Local Remedies - Lis Pedens - Amount and Form of Reasonable Bond - UN Convention on the Law of the Sea" (2000) 94 AJIL 713.

Oxman, Bernard H "Complementary Agreements and Compulsory Jurisdiction" (2001) 95 AJIL 277. 
Oxman, Bernard $\mathrm{H}$ and Barbara Kwiatkowska "Arbitration - Jurisdictional Effect of Different Dispute Settlement Provisions in Related Treaties - High Seas Fishing - Relationship between UN Convention on the Law of the Sea and Specialized Treaties" (2001) AJIL 162.

Oxman, Bernard and Vincent P Bantz "The 'Grand Prince' (Belize v. France)" (2002) 96 AJIL 219.

Oxman, Bernard "The International Tribunal for the Law of the Sea" in David D Caron and Harry N Scheiber (eds) Bringing New Law to Ocean Waters (Martinus Nijhoff Publishers, Leiden, 2004) 285.

Palmer, Geoffrey "New Ways to Make International Environmental Law" (1992) 86 AJIL 259.

Paparrigopoulos, Xenophon J "The Role of Courts in Crisis and Transition Periods: Courts as Image Makers" in Shimon Shetreet (ed) The Role of Courts in Society (Martinus Nijhoff Publishers, Dordrecht, 1988) 68.

Pardo, Arvid "New Institutions for Ocean Space" in Elisabeth Mann Borgese and David Krieger (eds) The Tides of Change: Peace, Pollution, and Potential of the Oceans (Mason/ Charter, New York, 1975) 324.

Pardo, Arvid "Perspectives on Ocean Governance" in Jon M Van Dyke, Durwood Zaelke and Grant Hewison (eds) Freedom for the Seas in the 21st Century: Ocean Governance and Environmental Harmony (Island Press, Washington DC, 1993) 38.

Park, Choon-Ho "Judicial Settlement of International Maritime Disputes - An Overview of the Current System" (1999) 28 Stetson L Rev 1035.

Pauwelyn, Joost "Judicial Mechanisms: Is there a Need for a World Environment Court?" in W Bradnee Chambers and Jessica F Green (eds) Reforming International Environmental Governance: From Institutional Limits to Innovative Reforms (United Nations University Press, Tokyo, 2005) 150.

Peel, Jacqueline "A Paper Umbrella which Dissolves in the Rain? The Future for Resolving Fisheries Disputes under UNCLOS in the Aftermath of the Southern Bluefin Tuna Arbitration" (2002) 3 Melb J Intl L 53.

Peel, Jacqueline "Precaution - A Matter of Principle, Approach or Process" (2004) 5 Melb J Intl L 483.

Peters, Anne "International Dispute Settlement: A Network of Cooperational Duties" (2003) 14 (1) EJIL 1.

Peters, J A "How to Reconcile Trade and Environment" in Wybo P Heere (ed) International Law and The Hague's $750^{\text {th }}$ Anniversary (TMC Asser Press, The Hague, 1999) 309. 
Peterson, M J "International Organizations and the Implementation of Environmental Regimes" in Oran R Young (ed) Global Governance: Drawing Insights from the Environmental Experience (The MIT Press, Cambridge (Mass), 2000) 115 .

Picciotto, Sol “The WTO's Appellate Body: Legal Formalism as Legitimation of Global Governance” (2005) 18 (3) Governance 477.

Picker, Colin B "A View from 40,000 Feet: International Law and the Invisible Hand of Technology" (2001) 23 Cardozo L Rev 149.

Pierce, George A "Dispute Settlement Mechanisms in the Draft Convention on the Law of the Sea" (1981) 10 Denv J Intl L \& Poly 331.

Pinto, M C W "The Prospects for International Arbitration: Inter-State Disputes" in A H A Soons (ed) International Arbitration: Past and Prospects (Martinus Nijhoff Publishers, Dordrecht, 1990) 63.

Piotrowicz, Ryszard "The Song of the Volga Boatmen - Please Release Me" (2003) 77 ALJ 160.

Platzöder, Renate "The International Tribunal for the Law of the Sea" in Mochtar Kusuma Atmadja, Thomas A Mensah and Bernard H Oxman (eds) Sustainable Development and Preservation of the Oceans: The Challenges of UNCLOS and Agenda 21 (The Law of the Sea Institute, University of Hawaii, Honolulu, 1997) 303.

Platzöder, Renate "Impact of Arbitration Established under Annex VII on the Implementation of the Law of the Sea Convention" in Davor Vidas and Willy Østreng (eds) Order for the Oceans at the Turn of the Century (Kluwer Law International, The Hague, 1999) 105.

Polacheck, Tom "Experimental Catches and the Precautionary Approach: The Southern Bluefin Tuna Dispute" (2002) 26 Marine Policy 283.

Popick, Ian J "Are There Really Plenty of Fish in the Sea? The World Trade Organization's Presence is Effectively Frustrating the International Community's Attempts to Conserve the Chilean Sea Bass" (2001) 50 Emory LJ 939.

Posner, Eric A and John C Yoo "Judicial Independence in International Tribunals" (2005) 93 Cal L Rev 1.

Posner, Eric A and John C Yoo "Reply to Helfer and Slaughter" (2005) 93 Cal L Rev 957.

Prager, D W "The Proliferation of International Judicial Organs: The Role of the International Court of Justice" in Niels M Blokker and Henry G Schermers (eds) Proliferation of International Organizations: Legal Issues (Kluwer Law International, The Hague, 2001) 278. 
Pureza, Jose Manuel "International Law and Ocean Governance: Audacity and Modesty" (1999) 8 (1) RECIEL 73.

Queneudec, Jean-Pierre "The Role of the International Court of Justice and Other Tribunals in the Development of the Law of the Sea" in Alfred H A Soons (ed) Implementation of the Law of the Sea Convention through International Institutions (Law of the Sea Institute, University of Hawaii, Honolulu, 1990) 574.

Rajagopal, Balakrisnan "From Resistance to Renewal: The Third World, Social Movements, and the Expansion of International Institutions" (2000) 41 (2) Harv Intl L J 529.

Rao, Chandrasekhara P "The International Tribunal for the Law of the Sea: An Evaluation" in Nisuke Endo and others (eds) Liber Amicorum Judge Shigeru Oda (vol 1, Kluwer Law International, The Hague, 2002) 667.

Rao, Pemmaraju Sreenivasa "Multiple International Judicial Forums: A Reflection of the Growing Strength of International Law or its Fragmentation?" (2004) Mich J Intl L 929.

Rashbrooke, Gwenaele "The International Tribunal for the Law of the Sea: A Forum for the Development of Principles of International Environmental Law?" (2004) 19 (4) IJMCL 515.

Rau, Markus "Comment: The Swordfish Case: Law of the Sea v Trade" (2002) 62 (1-2) ZaöRV 37.

Rayfuse, Rosemary "The Future of Compulsory Dispute Settlement Under the Law of the Sea Convention" (2005) 36 VUWLR 683.

Rayner, Steve "Mapping Institutional Diversity for Implementing the Lisbon Principles" (1999) 31 Ecological Economics 259.

Reinisch, August "The Use and Limits of Res Judicata and Lis Pendens as Procedural Tools to Avoid Conflicting Dispute Settlement Outcomes" (2004) 3 LPICT 37.

Rest, Alfred "Enhanced Implementation of International Environmental Treaties by Judiciary - Access to Justice in International Environmental Law for Individuals and NGOs: Efficacious Enforcement by the Permanent Court of Arbitration" (2004) 1 MqJICEL 1.

Rhodes, Roderick "The New Governance: Governing Without Government" (1996) 44 Political Studies 652.

Richardson, Elliot L "Dispute Settlement under the Convention on the Law of the Sea: A Flexible and Comprehensive Extension of the Rule of the Law to Ocean Space" in Thomas Buergenthal (ed) Contemporary Issues in International Law - Essays in Honor of Louis B Sohn (N P Engel, Kehl, 1984) 149. 
Richardson, Elliot L "Historical Evolution of the United Nations Convention on the Law of the Sea" (1995) 7 Geo Intl Envtl L Rev 639.

Riphagen, W "Mechanisms of Supervision in the Future Law of the Sea" in Frits Kalshoven, Pieter Jan Kuyper and Johan G Lammers (eds) Essays on the Development of the International Legal Order (Sijthoff \& Noordhoff, Alphen aan den Rijn (The Netherlands), 1980) 115.

Riphagen, W "Dispute Settlement in the 1982 United Nations Convention on the Law of the Sea" in Christos L Rozakis and Constantine A Stephanou The New Law of the Sea (North-Holland Publishing Company, Amsterdam, 1983) 281.

Ritchie-Calder, Lord "In Quiet Enjoyment" in Elisabeth Mann Borgese (ed) Pacem in Maribus (Dodd, Mead \& Company, New York, 1972) 260.

Roach, Ashley J "Dispute Settlement in Specific Situations" (1995) 7 Geo Intl Envtl L Rev 775.

Röben, Volker "The Sothern Bluefin Tuna Cases: Re-Regionalization of the Settlement of Law of the Sea Disputes?” (2002) 62 (1-2) ZaöRV 61.

Roch, Philippe and Franz Xaver Parrez "International Environmental Governance: The Strive Towards a Comprehensive, Coherent, Effective and Efficient International Environmental Regime" (2005) 16 Colo J Intl Envtl L \& Poly 1.

Romano, Cesare P R “The Southern Bluefin Tuna Dispute: Hints of a World to Come ... Like it or Not" (2001) 32 ODIL 313.

Romano, Cesare P R "International Justice and Developing Countries: A Quantitative Analysis” (2002) 1 LPICT 367.

Romano, Cesare P R "The Settlement of Disputes under the 1982 Law of the Sea Convention: How Entangled Can We Get?” (2004) 103 (1) J Intl L \& Diplo 84.

Rosenau, James N "Governance in the Twenty-first Century" (1995) 1 Global Governance 13.

Rosenau, J N "Citizenship in a Changing Global Order" in Rosenau and Czempiel (eds) Governance without Government: Order and Change in World Politics (Cambridge University Press, Cambridge, 1992) 291.

Rosenne, Shabtai "The Settlement of Disputes in the New Law of the Sea" (1978) 11-12 Reveu Iranniene Des Relations Internationales 401.

Rosenne, Shabtai "Settlement of Fisheries Disputes in the Exclusive Economic Zone" (1979) 73 AJIL 89. 
Rosenne, Shabtai "Establishing the International Tribunal for the Law of the Sea" (1995) 89 AJIL 806.

Rosenne, Shabtai "The International Tribunal for the Law of the Sea and the International Court of Justice: Some Points of Difference" in Renate Platzöder and Philomene Verlaan (eds) The Baltic Sea: New Developments in National Policies and International Cooperation (Martinus Nijhoff Publishers, The Hague, 1996) 200.

Rosenne, Shabtai "International Tribunal for the Law of the Sea: 1996-97 Survey” (1998) 13 (4) IJMCL 487.

Rosenne, Shabtai "International Tribunal for the Law of the Sea: 1998 Survey" (1999) 14 (4) IJMCL 453.

Rosenne, Shabtai "International Tribunal for the Law of the Sea: Survey for 1999” (2000) 15 (4) IJMCL 443.

Rosenne, Shabtai "The Case-Law of ITLOS (1997-2001): An Overview" in M H Nordquist and $\mathrm{J} \mathrm{N}$ Moore (eds) Current Marine Environmental Issues and the International Tribunal for the Law of the Sea (Kluwer Law International, The Hague, 2001) 127.

Rothwell, Donald R "Conflict Resolution and the Law of the Sea: Reconciling Interaction between the LOS Convention and Environmental Instruments" in Alexander Kiss, Dinah Shelton and Kanami Ishibashi (eds) Economic Globalization and Compliance with International Environmental Agreements (Kluwer Law International, The Hague, 2003) 255.

Rothwell, Donald R "The International Tribunal for the Law of the Sea and Marine Environmental Protection: Expanding the Horizons of International Oceans Governance" (2003) 17 Ocean Yearbook 26.

Rothwell, Donald R "Oceans Management and the Law of the Sea in the Twenty-First Century" in Alex G Oude Elferink and Donald R Rothwell (eds) Oceans Management in the 21st Century: Institutional Frameworks and Responses (Martinus Nijhoff Publishers, Leiden, 2004) 329.

Rothwell, Donald R and Tim Stephens "Dispute Resolution and the Law of the Sea: Reconciling the Interaction Between the LOS Convention and Other Environmental Instruments" in Alex G Oude Elferink and Donald R Rothwell (eds) Oceans Management in the 21st Century: Institutional Frameworks and Responses (Martinus Nijhoff Publishers, Leiden, 2004) 209.

Rothwell, Donald R and Tim Stephens "Illegal Southern Ocean Fishing and Prompt Release: Balancing Coastal and Flag State Rights and Interests" (2004) 53 ICLQ 171.

Rothwell, Donald R "Building on the Strengths and Addressing the Challenges: The Role of Law of the Sea Institutions" (2004) 35 ODIL 131. 
Rottem, Gideon "Compliance with International Standards: Environmental Case Studies" (1995) 89 Am Socy Intl L Proc 206.

Russ, Garry R and Dirk C Zeller "From Mare Liberum to Mare Reservarum" (2003) 27 (1) Marine Policy 75.

Philippe Sands "Compliance with International Environmental Obligations: Existing International Legal Arrangements" in James Cameron, Jacob Werksman and Peter Roderick (eds) Improving Compliance with International Environmental Law (Earthscan Publications Ltd, London, 1996) 48.

Sands, Philippe "ITLOS: An International Lawyer's Perspective" in M H Nordquist and J N Moore (eds) Current Marine Environmental Issues and the International Tribunal for the Law of the Sea (Kluwer Law International, The Hague, 2001) 141.

Sandner, Gerhard "Geopolitical Implications in the Law of the Sea in the Caribbean: The Interaction of Scale and Style in the Generation and Solution of Maritime 'Territorial' Conflicts" in Hance D Smith and Adalberto Vallega (eds) The Development of Integrated Sea-Use Management (Routledge, London, 1991) 86.

Sato, Yoichiro "Fishy Business: A Political - Economic Analysis of the Southern Bluefin Tuna Dispute" (2002) 28 (4) Asian Affairs: An American Review 217.

Schachter, Oscar "International Law in Theory and Practice: General Course in Public International Law" (1982) 178 Recueil des Cours 207.

Schachter, Oscar "Concepts and Realities in the New Law of the Sea" in Giulio Pontecorvo (ed) The New Order of the Oceans: The Advent of a Managed Environment (Columbia University Press, New York, 1986) 29.

Scheiber, Harry N "Ocean Governance and the Marine Fisheries Crisis: Two Decades of Innovation - and Frustration” (2001) 20 Va Envtl L J 119.

Schermers, Henry G "Exhaustion of Domestic Remedies" in Nisuke Endo and others (eds) Liber Amicorum Judge Shigeru Oda (vol 2, Kluwer Law International, The Hague, 2002) 947.

Schiffman, Howard Scott "The Protection of Whales in International Law: A Perspective for the Next Century" (1996) 22 Brook J Intl L 303.

Schiffman, Howard S "The Dispute Settlement Mechanism of UNCLOS: A Potentially Important Apparatus for Marine Wildlife Management" (1998) 1 (2) JIWLP 293.

Schiffman, Howard S "The Southern Bluefin Tuna Case: ITLOS Hears its First Fishery Dispute" (1999) 2 (3) JIWLP 1. 
Schiffman, Howard S "UNCLOS and Marine Wildlife Disputes: Big Splash or Barely a Ripple?” (2001) 4 JIWLP 257.

Schmidt Carl-Christian "Economic Drivers of Illegal, Unreported and Unregulated (IUU) Fishing" (2005) 20 (2-3) IJMCL 479.

Schofield, Clive "Cooperative Mechanisms and Maritime Security in Areas of Overlapping Claims to Maritime Jurisdiction" in Peter Cozens and Joanna Mossop (eds) Capacity Building for Maritime Security Cooperation in the AsiaPacific (Centre for Strategic Studies, Wellington, 2005) 99.

Schrijver, Nico "Practising International Law at the International Tribunal for the Law of the Sea: The Case Concerning Land Reclamation in and Around the Straits of Johor (Malaysia v Singapore), Application for Provisional Measures" (2005) 6 (1) Griffin's View 35.

Schroeder, Edward T “A Tort by Any Other Name? In Search of the Distinction Between Regulation Through Litigation and Conventional Tort Law" (2005) 83 Tex L Rev 897.

Schwarte, Christoph "Environmental Concerns in the Adjudication of the International Tribunal for the Law of the Sea" (2004) 16 Geo Intl Envtl L Rev 421.

Schwebel, Stephen M "The Contribution of the International Court of Justice to the Development of International Law" in Wybo P Heere (ed) International Law and The Hague's 750 ${ }^{\text {th }}$ Anniversary (TMC Asser Press, The Hague, 1999) 405.

Schwebel, Stephen M "The Southern Bluefin Tuna Case" in Nisuke Endo and others (eds) Liber Amicorum Judge Shigeru Oda (vol 1, Kluwer Law International, The Hague, 2002) 743.

Scott, Karen N "The Day After Tomorrow: Ocean $\mathrm{CO}_{2}$ Sequestration and the Future of Climate Change" (2005) 18 Geo Intl Envtl L Rev 57.

Scott, Shirley V “Australia's First Tuna Negotiations with Japan” (2000) 24 Marine Policy 309.

Scott, Shirley V "The Contribution of the LOS Convention Organizations to its Harmonious Implementation" in Alex G Oude Elferink and Donald R Rothwell (eds) Oceans Management in the 21st Century: Institutional Frameworks and Responses (Martinus Nijhoff Publishers, Leiden, 2004) 313.

Serdy, Andrew "The Paradoxical Success of UNCLOS Part XV: A Half-Hearted Reply to Rosemary Rayfuse" (2005) 36 VUWLR 713. 
Serdy, Andrew and Michael Bliss "Prompt Release of Fishing Vessels: State Practice in the Light of the Cases before the International Tribunal for the Law of the Sea" in Alex G Oude Elferink and Donald R Rothwell (eds) Oceans Management in the 21st Century: Institutional Frameworks and Responses (Martinus Nijhoff Publishers, Leiden, 2004) 273.

Shamsey, John "ITLOS vs Goliath: The International Tribunal for the Law of the Sea Stands Tall with the Appellate Body in the Chilean - EU Swordfish Dispute" (2002) 12 Trans Natl L \& Contemp Probs 513.

Shany, Yuval "The First MOX Plant Award: The Need to Harmonize Competing Environmental Regimes and Dispute Settlement Procedures" (2004) 17 LJIL 815.

Shearer, Ivan A "The Relationship Between International Law and Domestic Law" in Brian R Opeskin and Donald R Rothwell (eds) International Law and Australian Federalism (Melbourne University Press, Carlton South, Victoria, 1997) 34.

Shearer, Ivan A "Enforcement of Laws Against Delinquent Vessels in Australia's Maritime Zones" in Doug MacKinnon and Dick Sherwood (eds) Policing Australia's Offshore Zones: Problems and Prospects (Centre for Maritime Policy, University of Wollongong, Wollongong, 1997) 239.

Shearer, Ivan A "The International Tribunal for the Law of the Sea and its Potential for Resolving Navigational Disputes" in Donald R Rothwell and Sam Bateman (eds) Navigational Rights and Freedoms and the New Law of the Sea (Kluwer Law International, The Hague, 2000) 263.

Shearer, Ivan "Oceans Management Challenges for the Law of the Sea in the First Decade of the 21st Century" in Alex G Oude Elferink and Donald R Rothwell (eds) Oceans Management in the 21st Century: Institutional Frameworks and Responses (Martinus Nijhoff Publishers, Leiden, 2004) 1.

Sheehan, Anne "Dispute Settlement under UNCLOS: The Exclusion of Maritime Delimitation Disputes" (2005) 24 UQLJ 165.

Shinkaretskaia, G G "International Adjudication Today in the View of a Soviet International Lawyer" in William E Butler (ed) Perestroika and International Law (Martinus Nijhoff Publishers, Dordrecht, 1990) 245.

Shinkaretskaya, G "The Present and Future Role of International Adjudication as a Means for Peacefully Settling Disputes" (1989) 29 (1\&2) IJIL 87.

Shinkaretskaya, Galina G "International Arbitration in the External Policy of the Soviet Union" in Carty Anthony and Gennady Danilenko (eds) Perestroika and International Law: Current Anglo-Soviet Approaches to International Law (Edinburgh University Press, Edinburgh, 1990) 110. 
Side, Jonathan and Paul Jowitt "Technologies and their Influence on Future UK Marine Resource Development and Management" (2002) 26 Marine Policy 231.

Silk, Richard J Jr "Nonbinding Dispute Resolution Processes in Fisheries Conflicts: Fish Out of Water?" (2001) Ohio St J on Disp Resol 791.

Singh, Gurdip United Nations Convention on the Law of the Sea: Dispute Settlement Mechanisms (Academic Publications, Delhi, 1985).

Slade, Tuiloma Neroni "The Making of International Law: The Role of Small Island States" (2003) 17 Temp Intl \& Comp L J 531.

Smith, Hance D "The Role of the State in the Technical and General Management of the Oceans" (1995) 27 Ocean \& Coastal Management 5.

Smouts, Marie-Claude "The Proper Use of Governance in International Relations" (1998) 155 International Social Science Journal 81.

Sohn, Louis B "The Function of International Arbitration Today" (1963) I 108 Recueil des Cours 1.

Sohn, Louis B "A Tribunal for the Sea-Bed or the Oceans" (1972) 32 ZaöRV 253.

Sohn, Louis B "The Council of an International Sea-Bed Authority" (1972) 9 San Diego L Rev 404.

Sohn, Louis B "Settlement of Disputes Arising Out of the Law of the Sea Convention" (1975) 12 San Diego L Rev 495.

Sohn, Louis B "Towards a Tribunal for the Oceans" (1975-76) 5-6 Reveu Iranniene Des Relations Internationales 247.

Sohn, Louis B "US Policy toward the Settlement of Law of the Sea Disputes" (1976) 17 Va J Intl L 9.

Sohn, Louis B "Settlement of International Disputes Relating to Deep Sea-Bed Mining" in Festschrift für Rudolf Bindschedler Zum 65 Geburtstag am 8 Juli 1980 (Stämpfli \& Cie, Bern, 1980) 443.

Sohn, Louis B "The Role of Arbitration in Recent International Multilateral Treaties" (1982-83) 23 Va J Intl L 171.

Sohn, Louis B "Peaceful Settlement of Disputes in Ocean Conflicts: Does UNCLOS III Point the Way?” (1983) 46 Law \& Contemp Probs 195.

Sohn, Louis B "The Future of Dispute Settlement" in R St J Macdonald and Douglas M Johnston (eds) The Structure and Process of International Law: Essays in Legal Philosophy Doctrine and Theory (Martinus Nijhoff Publishers, The Hague, 1983) 1121. 
Sohn, Louis B "Peaceful Settlement of Disputes" in Mark W Janis (ed) International Courts for the Twenty - First Century (Martinus Nijhoff Publishers, Dordrecht, 1992) 3.

Sohn, Louis B "The Role of Dispute Settlement in Ocean Governance" in Thomas A Mensah (ed) Ocean Governance: Strategies and Approaches for the $21^{\text {st }}$ Century (The Law of the Sea Institute, University of Hawaii, Honolulu, 1994) 235.

Sohn, Louis B "The Importance of the Peaceful Settlement of Disputes Provisions of the United Nations Convention on the Law of the Sea" in M H Nordquist and J N Moore (eds) Entry into Force of the Law of the Sea Convention (Martinus Nijhoff Publishers, The Hague, 1995) 265.

Sohn, Louis B "Settlement of Law of the Sea Disputes" (1995) 10 (2) IJMCL 205.

Sohn, Louis B "Advisory Opinions by the International Tribunal for the Law of the Sea or Its Seabed Disputes Chamber" in Myron H Nordquist and John Norton Moore (eds) Oceans Policy: New Institutions, Challenges and Opportunities (Kluwer Law International, The Hague, 1999) 61.

Stephens, Tim “A Paper Umbrella Which Dissolves in the Rain? Implications of the Southern Bluefin Tuna Case for the Compulsory Resolution of Disputes Concerning the Marine Environment under the 1982 LOS Convention" (2001) 6 APJEL 297.

Stephens, Tim "Enforcing Australian Fisheries Laws: Testing the Limits of Hot Pursuit in Domestic and International Law" (2004) 15 (1) PLR 12.

Stephens, Tim "The Limits of International Adjudication in International Environmental Law: Another Perspective on the Southern Bluefin Tuna Case" (2004) 19 (2) IJMCL 177.

Stephens, Tim and Donald R Rothwell "Law of the Sea: An Article 292 Bond Must be Reasonable in Amount in Light of Both the Interest of a Flag State in the Prompt Release of its Fishing Vessel and that of the Coastal State in Securing the Appearance of the Master in Court and the Payment of Fines; It Cannot Include an Amount Guaranteeing Future 'Good Behaviour,' and the Value of the Catch is Irrelevant to its Calculation. The Volga (Russian Federation v Australia) ITLOS No 11 (23 December 2002)" (2004) 35 J Mar L \& Com 283.

Stern, Paul and others "Knowledge and Questions After 15 Years of Research" in Elinor Ostrom and others (eds) The Drama of the Commons (National Academy Press, Washington DC, 2002) 445.

Stevenson, John R and Bernard H Oxman "The Preparations for the Law of the Sea Conference" (1974) 68 AJIL 1. 
Stevenson, John R and Bernard H Oxman "The Third United Nations Conference on the Law of the Sea: The 1974 Caracas Session" (1975) 69 AJIL 1.

Stevenson, John R and Bernard H Oxman "The Third United Nations Conference on the Law of the Sea: The 1975 Geneva Session" (1975) 69 AJIL 763.

Stevenson, John R and Bernard H Oxman "The Future of the United Nations Convention on the Law of the Sea" (1994) 88 AJIL 488.

Stokke, Olav Schram "Governance of High Seas Fisheries: The Role of Regime Linkages" in Davor Vidas and Willy Østreng (eds) Order for the Oceans at the Turn of the Century (Kluwer Law International, The Hague, 1999) 157.

Stoll, Peter-Tobias and Silja Vöneky "The Swordfish Case: Law of the Sea v Trade" (2002) 62 (1-2) ZaöRV 21.

Sturtz, Leah "Southern Bluefin Tuna Case: Australia and New Zealand v Japan" (2001) 28 Ecology L Q 455.

Suarez de Vivero, Juan Luis and Juan Carlos Rodriguez Mateos "New Factors in Ocean Governance: From Economic to Security-Based Boundaries" (2004) 28 Marine Policy 185.

Swing, John Temple "Who Will Own the Oceans?" (1976) 54 (3) Foreign Aff 527.

Swing, John Temple "What Future for the Oceans?" (2003) 82 (5) Foreign Aff 139.

Sydnes, Are K, Alf Hakon Hoel and Syma A Ebbin "Changing Seas, Changing Institutions: Charting New Courses into the Future" in Syma A Ebbin, Alf Hakon Hoel and Are K Sydnes (eds) A Sea Change: The Exclusive Economic Zone and Governance Institutions for Living Marine Resources (Springer, Dordrecht, 2005) 210.

Talhelm, Jennifer L "Curbing International Overfishing and the Need for Widespread Ratification of the United Nations Convention on the Law of the Sea" (2000) N C J Intl L \& Com Reg 381.

Tanaka, Maki "Lessons from the Protracted MOX Plant Dispute: A Proposed Protocol on Marine Environmental Impact Assessment to the United Nations Convention on the Law of the Sea" (2004) 25 Mich J Intl L 337.

Tanaka, Yoshifumi "Prompt Release in the United Nations Convention on the Law of the Sea: Some Reflections on the ITLOS Jurisprudence" (2004) 51 (2) NILR 237.

Tanaka, Yoshifumi "Zonal and Integrated Management Approaches to Ocean Governance: Reflections on a Dual Approach in International Law of the Sea" (2004) 19 (4) IJMCL 483. 
Telesca, Thomas A "Sovereignty or the Precautionary Principle: Which Will Save Our Fish?” (2003) 12 Southeastern Envtl L J 23.

Thirlway, Hugh "The Proliferation of the International Judicial Organs and the Formation of International Law" in Wybo P Heere (ed) International Law and The Hague's 750 ${ }^{\text {th }}$ Anniversary (TMC Asser Press, The Hague, 1999) 433.

Tieya, Wang "The Third World and International Law" in R St J Macdonald and Douglas M Johnston (eds) The Structure and Process of International Law: Essays in Legal Philosophy Doctrine and Theory (Martinus Nijhoff Publishers, The Hague, 1983) 955.

Toepfer, Klaus "Message" in United Nations Environment Programme UNEP Global Judges Programme (United Nations Environment Programme, Nairobi, 2005) v.

Treves, Tullio "Accommodation of Multiple Uses of the Sea in International Law, With Special Reference to the Mediterranean" in Douglas M Johnston and Norman G Letalik (eds) in The Law of the Sea and Ocean Industry: New Opportunities and Restraints (Law of the Sea Institute, University of Hawaii, Honolulu, 1983) 51.

Treves, Tullio "The Law of the Sea Tribunal: Its Status and Scope of Jurisdiction after November 16, 1994" (1995) 55 (2) ZaöRV 421.

Treves, Tullio "The Proceedings Concerning Prompt Release of Vessels and Crews before the International Tribunal for the Law of the Sea" (1996) 11 (2) IJMCL 179.

Treves, Tullio "Dispute-Settlement Clauses in the Law of the Sea Convention and their Impact on the Protection of the Marine Environment: Some Observations" (1999) 8 (1) RECIEL 6.

Treves, Tullio "Conflicts Between the International Tribunal for the Law of the Sea and the International Court of Justice" (1999) 31 N Y U J Intl L \& Pol 809.

Treves, Tullio "Advisory Opinions of the International Court of Justice on Questions Raised by Other International Tribunals" (2000) 4 Max Planck Yrbk UN L 215.

Treves, Tullio "The Role of Dispute Settlement Mechanisms in the Protection of the Marine Environment in Cases Concerning Economic Activities in the Sea and Seabed" in The International Bureau of the Permanent Court of Arbitration (eds) International Investments and Protection of the Environment (Kluwer Law International, Boston, 2001) 97. 
Treves, Tullio "The Jurisdiction of the International Tribunal for the Law of the Sea" in P Chandrasekhara Rao and Rahmatullah Khan (eds) International Tribunal for the Law of the Sea: Law and Practice (Kluwer Law International, The Hague, 2001) 111.

Treves, Tullio "Advisory Opinions under the Law of the Sea Convention" in M $\mathrm{H}$ Nordquist and J N Moore (eds) Current Marine Environmental Issues and the International Tribunal for the Law of the Sea (Kluwer Law International, The Hague, 2001) 81.

Treves, Tullio "International Organisations as Parties to Contentious Cases: Selected Cases" in Laurence Boisson de Chazournes, Cesare P R Romano and Ruth Mackenzie (eds) International Organizations and International Dispute Settlement: Trends and Prospects (Transnational Publishers Inc, Ardsley, (New York) 2002) 37.

Treves, Tullio "Preliminary Proceedings in the Settlement of Disputes under the United Nations Law of the Sea Convention: Some Observations" in Nisuke Endo and others (eds) Liber Amicorum Judge Shigeru Oda (vol 1, Kluwer Law International, The Hague, 2002) 749.

Treves, Tullio "Flags of Convenience Before the Law of the Sea Tribunal" (2004) 6 San Diego Intl L J 179.

Treves, Tullio "The Law of the Sea Convention Ten Years After Entry Into Force: Positive Developments and Reasons for Concerns" in David D Caron and Harry N Scheiber (eds) Bringing New Law to Ocean Waters (Martinus Nijhoff Publishers, Leiden, 2004) 349.

Treves, Tullio “Judicial Lawmaking in an Era of 'Proliferation' of International Courts and Tribunals: Development or Fragmentation of International Law?" in Rüdiger Wolfrum and Volker Röben (eds) Developments of International Law in Treaty Making (Springer, Berlin, 2005) 586.

Tsamenyi, Martin B "Mechanisms for Integrated Resource Management" in Mochtar Kusuma Atmadja, Thomas A Mensah and Bernard H Oxman (eds) Sustainable Development and Preservation of the Oceans: The Challenges of UNCLOS and Agenda 21 (The Law of the Sea Institute, University of Hawaii, Honolulu, 1997) 414.

Tsamenyi, Martin and Kwame Mfodwo "Enforcing Fisheries Jurisdiction in the EEZ: Some Legal and Policy Considerations" in Doug MacKinnon and Dick Sherwood (eds) Policing Australia's Offshore Zones: Problems and Prospects (Centre for Maritime Policy, University of Wollongong, Wollongong, 1997) 254.

Tutangata, Tamari'i and Mary Power "The Regional Scale of Ocean Governance Regional Cooperation in the Pacific Islands" (2002) 45 Ocean \& Coastal Management 873. 
Tyagi, Yogesh K "The System of Settlement of Disputes Under the Law of the Sea Convention: An Overview” 25 (2) Indian J Intl L 191.

Ulfstein, Geir "The Conflict Between Petroleum Production, Navigation and Fisheries in International Law" (1988) 19 ODIL 229.

Valaskakis, Kimon "Long-term Trends in Global Governance: From 'Westphalia' to 'Seattle"' in Governance in the 21st Century (Organisation for Economic Co-operation and Development, Paris, 2001) 45.

Vallega, Adalberto "Ocean Governance in Post-modern Society - A Geographical Perspective” (2001) 25 Marine Policy 399.

Van Dyke, Jon M "International Governance and Stewardship of the High Seas and its Resources" in Jon M Van Dyke, Durwood Zaelke and Grant Hewison (eds) Freedom for the Seas in the 21st Century: Ocean Governance and Environmental Harmony (Island Press, Washington DC, 1993) 13.

Van Dyke, Jon M "Louis B. Sohn and the Settlement of Ocean Disputes" (2000) 33 Geo Wash Intl L Rev 31.

Van Dyke, Jon $M$ "The Evolution and International Acceptance of the Precautionary Principle" in David D Caron and Harry N Scheiber (eds) Bringing New Law to Ocean Waters (Martinus Nijhoff Publishers, Leiden, 2004) 357.

Van Dyke, Jon M "Giving Teeth to the Environmental Obligations in the LOS Convention" in Alex G Oude Elferink and Donald R Rothwell (eds) Oceans Management in the 21st Century: Institutional Frameworks and Responses (Martinus Nijhoff Publishers, Leiden, 2004) 167.

Veitayaki, Joeli, Nathan Evans and G Robin South "The Pacific Islands Regional Ocean Policy: The Quest for Good Ocean Governance" (2004) 18 Ocean Yearbook 558.

Vicuña, Francisco Orrego "The Role of the International Court of Justice and Other Tribunals in the Development of the Law of Maritime Delimitation" in Alfred H A Soons (ed) Implementation of the Law of the Sea Convention through International Institutions (Law of the Sea Institute, University of Hawaii, Honolulu, 1990) 601.

Vicuña, Francisco Orrego "Coastal States' Competences over High Seas Fisheries and the Changing Role of International Law" (1995) 55 (2) ZaöRV 520.

Vicuña, Francisco Orrego "From the 1893 Bering Sea Fur-Seals Case to the 1999 Southern Bluefin Tuna Cases: A Century of Efforts at Conservation of the Living Resources of the High Seas" (1999) 10 YIEL 41. 
Vidas, Davor "IUU Fishing or IUU Operations? Some Observations on Diagnosis and Current Treatment" in David D Caron and Harry N Scheiber (eds) Bringing New Law to Ocean Waters (Martinus Nijhoff Publishers, Leiden, 2004) 125.

Vukas, Budislav "Possible Role of the International Tribunal for the Law of the Sea in Interpretation and Progressive Development of the Law of the Sea" in Davor Vidas and Willy Østreng (eds) Order for the Oceans at the Turn of the Century (Kluwer Law International, The Hague, 1999) 95.

Vukas, Budislav "Main Features of Courts and Tribunals Dealing with Law of the Sea Cases" in M H Nordquist and J N Moore (eds) Current Marine Environmental Issues and the International Tribunal for the Law of the Sea (Kluwer Law International, The Hague, 2001) 217.

Wegelein, Florian H Th "The Rules of the Tribunal in the Light of Prompt Release of Vessels" (1999) 30 ODIL 255.

Weiss, Thomas G "Governance, Good Governance and Global Governance: Conceptual and Actual Challenges" (2000) 21 (5) TWQ 795.

White, Michael and Stephen Knight 'ITLOS and the 'Volga' Case: The Russian Federation v Australia” (2003) 17 MLAANZ Journal 39.

Willett, Linda A "Litigation as an Alternative to Regulation: Problems Created by Follow-on Lawsuits with Multiple Outcomes" (2005) 18 Geo J Legal Ethics 1477.

Wolfrum, Rüdiger "Means of Ensuring Compliance with and Enforcement of International Environmental Law" (1998) 272 Recueil des Cours 25.

Wolfrum, Rüdiger "The Role of the International Tribunal for the Law of the Sea" in Myron H Nordquist and John Norton Moore (eds) Current Fisheries Issues and the Food and Agriculture Organization of the United Nations (Martinus Nijhoff Publishers, The Hague, 2000) 369.

Wolfrum, Rüdiger "Provisional Measures of the International Tribunal for the Law of the Sea" in P Chandrasekhara Rao and Rahmatullah Khan (eds) International Tribunal for the Law of the Sea: Law and Practice (Kluwer Law International, The Hague, 2001) 173.

Wolfrum, Rüdiger "Implementation of Decisions of International Courts" in M H Nordquist and J N Moore (eds) Current Marine Environmental Issues and the International Tribunal for the Law of the Sea (Kluwer Law International, The Hague, 2001) 103.

Yamada, Chusei "Priority Application of Successive Treaties Relating to the Same Subject Matter: The Southern Bluefin Tuna Case" in Nisuke Endo and others (eds) Liber Amicorum Judge Shigeru Oda (vol 1, Kluwer Law International, The Hague, 2002) 763. 
Yang, Haijiang "Dispute Settlement Procedures for Foreign Merchant Ships" (2005) 20 (1) IJMCL 117.

Yankov, Alexander and Mario Ruivo "An Ocean Assembly" in Peter Bautista Payoyo (ed) Ocean Governance: Sustainable Development of the Seas (United Nations University Press, Tokyo, 1994) 330.

Yankov, Alexander "The International Tribunal for the Law of the Sea and the Comprehensive Dispute Settlement System of the Law of the Sea" in P Chandrasekhara Rao and Rahmatullah Khan (eds) International Tribunal for the Law of the Sea: Law and Practice (Kluwer Law International, The Hague, 2001) 33.

Yankov, Alexander "Current Fisheries Disputes and the International Tribunal for the Law of the Sea" in M H Nordquist and J N Moore (eds) Current Marine Environmental Issues and the International Tribunal for the Law of the Sea (Kluwer Law International, The Hague, 2001) 223.

Yankov, Alexander "Irregularities in Fishing Activities and the Role of the International Tribunal for the Law of the Sea" in Nisuke Endo and others (eds) Liber Amicorum Judge Shigeru Oda (vol 1, Kluwer Law International, The Hague, 2002) 773.

Young, Oran R "Institutional Interplay: The Environmental Consequences of Cross-Scale Interactions" in Elinor Ostrom and others (eds) The Drama of the Commons (National Academy Press, Washington DC, 2002) 263.

Zekos, Georgios I "Arbitration as a Dispute Settlement Mechanism under UNCLOS, The Hamburg Rules, and the WTO” (2002) 19 (5) J Intl Arb 497.

Zeller, Dirk "From Mare Liberum to Mare Reservarum: Canada's Opportunity for Global Leadership in Ocean Resource Governance" (2005) 19 Ocean Yearbook 1.

\section{CONFERENCE PAPERS}

Goff, Phil "International Institutions and Governance: A New Zealand Perspective" in International Governance And Institutions: What Significance For International Law? Proceedings of the Eleventh Annual Conference of the Australian and New Zealand Society of International Law (Wellington, 2003) 1.

Nandan, Satya N "Multilateral Oceans Governance and the International Seabed Authority" in International Governance And Institutions: What Significance For International Law? Proceedings of the Eleventh Annual Conference of the Australian and New Zealand Society of International Law (Wellington, 2003) 300 . 
Nelson, Dolliver "The Volga Case" in 2003 Frank Stuart Dethridge Memorial Address, MLAANZ Annual Conference (Brisbane, 2003) reproduced in (2004) 18 MLAANZ Journal 7.

Nichols, Sue and David Monahan "Fuzzy Boundaries in a Sea of Uncertainty" in The Coastal Cadastre - Onland, Offshore, Proceedings of the New Zealand Institute of Surveyors Annual Meeting (Bay of Islands, New Zealand, 1999) 33.

Nzongola-Ntalaja, Georges "Good Governance and Conflict Management: Will the African Union Make a Difference?" in Forum Evening, CCM's Norwegian Peacebuilding Empowerment Programme (Oslo, 2002).

Sohn, Louis B in United Nations Conference on the Law of the Sea - Panel Discussion at the Annual Meeting of the American Bar Association Section of International Law (1978) 12 (1) Intl Law 51.

Sutherland, Michael and Susan Nichols "Maritime Boundary Delimitation for Ocean Governance" in FIG Technical Program Proceedings, XXII FIG International Congress (Washington DC, 2002).

Vince, Joanna "Policy Transfer in Ocean Governance: Australia, Canada and New Zealand" in Australasian Political Studies Association Conference 2005 (Stream: Marine and Antarctic Politics, Dunedin, 2005).

\section{INTERNET RESOURCES}

Avgerinopoulou, Dionysia - Theodora "The Role of the International Judiciary in the Settlement of Environmental Disputes and Alternative Proposals for Strengthening International Environmental Adjudication" in Global Environmental Governance: The Post-Johannesburg Agenda (Yale Centre for Environmental Law and Policy, New Haven, 2003) 4, available at $<$ http://www.yale.edu/gegdialogue/docs/dialogue/oct03/papers/Avgerinopoulou. pdf $>$ (last accessed 6 December 2005).

Burgess, Heidi and Brad Spangler "The Difference Between Conflict and Dispute" in Guy Burgess and Heidi Burgess (eds) Dispute Resolution Consortium (University of Colorado, Boulder, Colorado, 2003) available at $<$ http://www.beyondintractability.org/m/conflicts_disputes.jsp $>$ (last accessed 5 November 2005).

Coalition of Legal Toothfish Operators "The Alphabet Boats: A Case Study of Toothfish Poaching in the Southern Ocean" available at $<$ http://www.colto.org/PDFs/Alphabet_Soup.pdf $>$ (last accessed 26 October 2005).

Coalition of Legal Toothfish Operators "Rogues Gallery: The New Face of IUU Fishing for Toothfish" (2003) available at $<$ http://www.colto.org/PDFs/RoguesGallery.pdf $>$ (last accessed 26 October 2005). 
Crutzen, Paul J and Eugene F Stoermer "The Anthropocene" (2000) 41 Global Change Newsletter 17. Available at $<$ http://www.igbp.kva.se//uploads/nl_41.pdf> (last accessed 22 November 2005).

Division for Ocean Affairs and the Law of the Sea $<$ http://www.un.org/Depts/los/index.htm> (last accessed 8 February 2006).

Division for Ocean Affairs and the Law of the Sea "Settlement of disputes mechanism - $\quad$ Recapitulative Tables", $<\mathrm{http}: / /$ www.un.org/Depts/los/settlement_of_disputes/choice_procedure.htm $>$ (last accessed 1 December 2005).

Division for Ocean Affairs and the Law of the Sea "Declarations and Statements" $<\mathrm{http}$ ://www.un.org/Depts/los/convention_agreements/convention_declarations.h tm> (last accessed 1 December 2005).

Division for Ocean Affairs and the Law of the Sea $<\mathrm{http}$ ://www.un.org/Depts/los/reference_files/chronological_lists_of_ratification s.htm\#The United Nations Convention on the Law of the Sea $>$ (last accessed 1 December 2005).

Donovan, Thomas W "Guyana Invokes Annex VII of the United Nations Convention on the Law of the Sea Against Suriname for Disputed Maritime Boundary" (2004) ASIL Insights, available at $<$ http://www.asil.org/insights/insigh131.htm> (last accessed 10 January 2006). Environmental Justice Foundation Pirates \& Profiteers: How Pirate Fishing Fleets are Robbing People and Oceans (Environmental Justice Foundation, London, 2005) available at $<\mathrm{http}$ //www.ejfoundation.org/pdfs/pirates_and_profiteers.pdf $>$ (last accessed 18 October 2005).

European Commission "What is Governance?" $<$ http://europa.eu.int/comm/governance/index_en.htm $>$ (last accessed 20 October 2005).

Food and Agriculture Organisation, Fisheries $<$ http://www.fao.org/fi/default_all.asp> (last accessed 1 December 2005).

Fridtjof Nansen Institute "An Acute Issue in Ocean Governance" (2003) 1 Nansen News, available at <http://www.fni.no/nanew/NN1-03-web.pdf $>$ (last accessed 26 November 2005).

Fukuda-Parr, Sakiko and Richard Ponzio "Governance: Past, Present and Future - Setting the Governance Agenda for the Millennium Declaration" $<$ http://www.undp.org/governance/docsaccount/gov-past-present-future.pdf $>$ (last accessed 20 October 2005).

Garcia, Serge "Fisheries Governance" <http://www.oceansatlas.org > (last accessed 1 November 2005). 
General Public Comment from the National Ocean Industries Association and others to the United States Commission on Ocean Policy (2002), available at $<\mathrm{http}$ //www.oceancommission.gov/publicomment/novgencomment/fry_comme nt.pdf $>$ (last accessed 15 November 2005).

Joint Group of Experts on the Scientific Aspects of Marine Environmental Protection <http://gesamp.imo.org/publicat.htm> (last accessed 11 November 2005).

Graham, John, Bruce Amos and Tim Plumptre "Principles of Good Governance in the $21^{\text {st }}$ Century" (2003) Policy Brief No 15, Institute on Governance $<$ http://www.iog.ca/publications/policybrief15.pdf $>$ (last accessed 25 October 2005).

Greenpeace Freedom for the Seas, for Now \& for the Future: Greenpeace Proposals to Revolutionise High Seas Oceans Governance (Greenpeace International, Amsterdam, 2005), available at $<\mathrm{http}$ ://www.greenpeace.org/raw/content/international/press/reports/freedomfor-seas.pdf $>$ (last accessed 15 November 2005).

Group of $77<$ http://www.g77.org/> (last accessed 4 February 2005).

Heinrich, Jason "Legal Implications of Ocean $\mathrm{CO}_{2}$ Storage" (2002) Working Paper, Laboratory for Energy and the Environment, Massachusetts Institute of Technology, available at $<\mathrm{http} / /$ sequestration.mit.edu/pdf/Legal_Implications_Ocean_Storage.pdf $>$ (last accessed 6 December 2005).

Hertin, J, Ian C Scoones and Frans Berkhout "Can Environmental and Trade Objectives be Better Integrated?" in Who Governs the Global Environment? (The Economic and Social Research Council, Swindon, 2000) available at $<$ http://www.gecko.ac.uk/governance.pdf $>$ (last accessed 11 November 2005).

Institute on Governance "Uncharted Waters: The Need for Integrated Oceans Governance" (April 2005) News, News, News $<$ http://www.iog.ca/news/apr2005.pdf> (last accessed 19 October 2005).

International Institute for Sustainable Development "A Summary Report of the High-Level Meeting on Compliance with and Enforcement of Multilateral Environmental Agreements: 21 - 22 January 2006" (2006) available at $<$ http://www.iisd.ca/ymb/unepmea/> (last accessed 26 January 2006).

International Institute for Sustainable Development "A Summary Report of The Ocean Policy Summit (TOPS): 11 - 13 October 2005" (2005) available at $<$ http://www.iisd.ca/sd/tops2005/> (last accessed 17 October 2005). 
International Institute for Sustainable Development "A Summary Report of the Third Global Conference on Oceans, Coasts and Islands 'Moving the Global Oceans Agenda Forward': 24 - 28 January 2006" (2006) available at $<$ http://www.iisd.ca/ymb/globaloceans3/> (last accessed 31 January 2006).

International Ocean Institute Training on Ocean Affairs, Business Strategy 2005 $-2008<\mathrm{http}: / / \mathrm{www}$.ioinst.org/> (last accessed 20 October 2005).

International Tribunal for the Law of the Sea Trust Fund $<$ http://www.un.org/Depts/los/ITLOS/itlos_trust_fund.htm $>$ (last accessed 10 February 2005).

Molenaar, Erik Jaap and Martin Tsamenyi "Satellite Based Vessel Monitoring Systems (VMSs) for Fisheries Management - International Legal Aspects and Developments in State Practice" (FAO Legal Paper Online \#7, April 2000) available at <http://www.fao.org/Legal/prs-ol/lpo7.pdf> (last accessed 20 October 2005).

Multilateral Treaties Deposited with the Secretary-General, Optional Protocol of Signature Concerning the Compulsory Settlement of Disputes $<$ http://untreaty.un.org/ENGLISH/bible/englishinternetbible/partI/chapterXXI/tre aty5.asp > (last accessed 2 December 2004).

Murphy, Lesley "EC and Chile Reach Agreement on 10-year Swordfish Dispute" (2001) 4 Int-Fish Bulletin, available at $<$ http://www.oceanlaw.net/bulletin/sample/focus/0102c.htm $>$ (last accessed 20 December 2005).

Nandan, Satya N "Current Fisheries Governance" in Conference on the Governance of High Seas Fisheries and the UN Fish Agreement - Moving From Words to Action (St. John's, Newfoundland and Labrador, 2005) available at $<$ http://www.dfo-mpo.gc.ca/fgc-cgp/documents/presentations/nandan_e.pdf $>$ (last accessed 20 November 2005).

National Environmental Trust Destined for Extinction: The Fate of Chilean Sea Bass (National Environmental Trust, Washington DC, 2001) available at $<$ http://www.net.org/relatives/4300.pdf $>$ (last accessed 28 October 2005).

National Environmental Trust Black Market for White Gold: The Illegal Trade in Chilean Sea Bass (National Environmental Trust, Washington DC, 2004) available at $<$ http://www.net.org/reports/csb_report.pdf $>$ (last accessed 4 August 2005).

Ng'ang'a, Sam and others "Toward a Multidimensional Marine Cadastre in Support of Good Ocean Governance" in International Conference on Spatial Information for Sustainable Development (Nairobi, 2001), available at $<$ http://www.fig.net/pub/proceedings/nairobi/nganga-nichols-sutherlandcockburn-TS12-3.pdf $>$ (last accessed 26 October 2005). 
Nichols, Sue "It's Our Ocean: How Well Will We Govern it?" in Offshore Issues Consultation Workshop, Association of Canada Lands Surveyors (Halifax, 2001), available

$<$ http://gge.unb.ca/Research/OceanGov/documents/LUNCH.PPT $>$ (last accessed 14 November 2005).

Oceans and Law of the Sea <http://www.un.org/Depts/los/index.htm> (last accessed 26 August 2005).

Office of the High Representative for the Least Developed Countries, Landlocked Developing Countries and Small Island Developing States $<$ http://www.un.org/special-rep/ohrlls/ohrlls/default.htm $>$ (last accessed 4 February 2005).

Orellana, Marcos A "The EU and Chile Suspend the Swordfish Case Proceedings at the WTO and the International Tribunal of the Law of the Sea" (2001) 60 ASIL Insights, available at <http://www.asil.org/insights/insigh60.htm> (last accessed 20 December 2005).

Posner, Eric A and John C Yoo "A Theory of International Adjudication" in International Legal Studies Working Papers Series (Paper 1, International Legal Studies Program, University of California, Berkeley, 2004) $<\mathrm{http}$ //repositories.cdlib.org/ils/wp/1> (last accessed 10 September 2005).

Purdy, Ray and Richard Mcrory "Geological Carbon Sequestration: Critical Legal Issues" (2004) Working Paper 45, Tyndall Centre for Climate Change Research, available at $<$ http://www.earthscape.org/r1/ES15586/wp45.pdf $>$ (last accessed 6 December 2005).

Reich, Robert B "Regulation is Out, Litigation is In" (February 1999) The American Prospect Online, available at $<$ http://www.prospect.org/webfeatures/1999/02/reich-r-02-11.html $>\quad$ (last accessed 11 November 2005).

Report of the Working Group No 5 on Governance "Strengthening Europe's Contribution to World Governance" in White Paper on Governance: An EU Contribution to Better Governance Beyond Our Borders (2001) $<$ http://europa.eu.int/comm/governance/areas/group11/report_en.pdf $>$ (last accessed 21 October 2005).

Rothwell, Donald R and Tim Stephens "The 'Volga' Case (Russian Federation v Australia): Prompt Release and the Right and Interests of Flag and Coastal States" in Conference Proceedings - Multilateralism and International Ocean Resources Law (Paper 20031, Law of the Sea Institute, University of California, Berkeley, 2003) <http://repositories.cdlib.org/losi/cp/20031/> (last accessed 7 September 2005).

Seas, Oceans and Small Islands (2004) 15 (1) Our Planet, available at $<$ http://www.ourplanet.com/imgversn/151/images/Our_Planet_15.1_english.pdf $>$ (last accessed 11 November 2005). 
Status of Multilateral Treaties Deposited with the Secretary-General $<$ http://untreaty.un.org/ENGLISH/bible/englishinternetbible/bible.asp $>$ (last accessed 1 December 2005).

Stokke, Olav Schram and Clare Coffey "Institutional Interaction in the High Seas Fisheries Management: An Inventory" in Sebastian Oberthür (co-ordinator) Institutional Interaction: How to Prevent Conflicts and Enhance Synergies Between International and EU Environmental Institutions (Project Deliverable No D8, Ecologic - Institute for International and European Environmental Policy Berlin, 2001), available at $<\mathrm{http}: / / \mathrm{www}$.ecologic.de/ $>$ (last accessed 20 November 2005).

Terms of reference of the Assistance Fund, available at $<$ http://www.un.org/Depts/los/convention_agreements/fishstocktrustfund/fishsto cktrustfund.htm $>$ (last accessed 10 February 2005).

The Least Developed Countries <http://r0.unctad.org/ldcs/> (last accessed 4 February 2005).

The World Bank FAQs “About Development" < http://www.worldbank.org/faqs $>$ (last accessed 2 December 2005).

The World "About Gank Governance" $<$ http://www.worldbank.org/wbi/governance/about.html $>$ (last accessed 20 October 2005).

Third Informal Consultations of the States Parties to the Agreement for the Implementation of the Provisions of the United Nations Convention on the Law of the Sea of 10 December 1982 relating to the Conservation and Management of Straddling Fish Stocks and Highly Migratory Fish Stocks, New York 8-9 July $2004,<$ http://www.un.org/Depts/los/convention_agreements/convention_overvie w_fish_stocks.htm $>$ (last accessed 10 February 2005 ).

United Nations Development Programme Strategy Note on Governance for Human Development, 2004 cited in Communications Office of the United Nations Development Programme/ Programme of Assistance to the Palestinian People "Good Governance" (2005) 1 Focus, 3 available at $<$ http://www.papp.undp.org/> (last accessed 20 October 2005).

United Nations Development Programme "Promoting Conflict Prevention and Conflict Resolution Through Effective Governance: A Conceptual Study and Literature Review" <http://magnet.undp.org/Docs/crisis/mapexercise.htm $>$ (last accessed 20 October 2005).

VanderZwaag, David, Sean LeRoy and Rod Dobell "Ocean Governance" in Workshop Backgrounders: 2003 OMRN Conference (Ottawa, 2003), available at $<$ http://www.maritimeawards.ca/OMRN/vanderzwaag.pdf $>$ (last accessed 15 November 2005). 


\section{NEWS AGENCY}

Carsten Hoefer "International Sea Court to Calm the World's Stormy Seas" (4 December 1997) Deutsche Presse-Agentur Hamburg.

\section{NON - LAW RELATED MATERIAL}

Frost, Robert "Mending Wall" in Edward Connery Lathem (ed) The Poetry of Robert Frost: The Collected Poems, Complete and Unabridged (Henry Holt \& Company, New York, 1969) 33.

Heller, Heller Catch - 22 (Corgi Books, London, 1964).

Milton, John "Paradise Regained - Book IV" in The Poetical Works of Milton (vol 2, Printed for the Booksellers, London, 1790) 71. 